ما نسبه الزبيدي في تاج العروس إلى اللهجة المصرية

ما نسبه الزبيدي في تاج العروس إلى اللهجة المصرية

\title{
جمعا ودراسة
}

$$
\text { إعــداد }
$$

د/ مصطفى عبد الهادي عبد الستار محمد إعلدال

المدرس في كلية اللغة العربية بالمنوفية العبار

جامعة الأزهر

ملخص البحث

الإمام الزبيدي اللغوي المحدث الفقية الصوفي، يعد بحق أحد رواد اللغة المتأخرين، وأئعنها

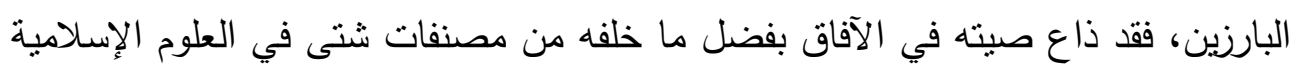

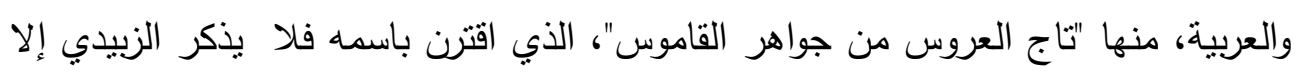

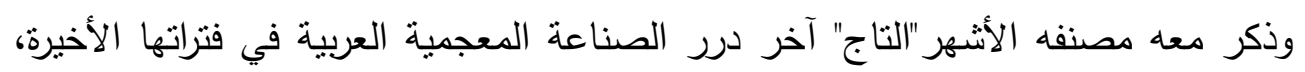

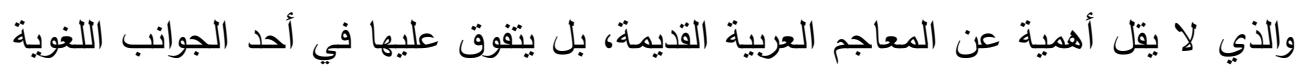

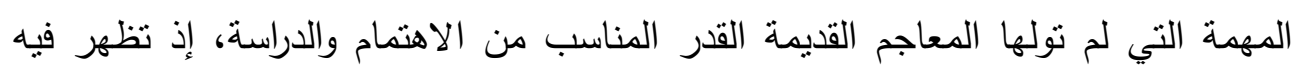

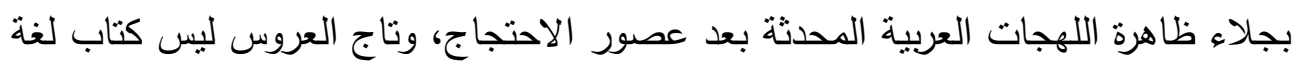

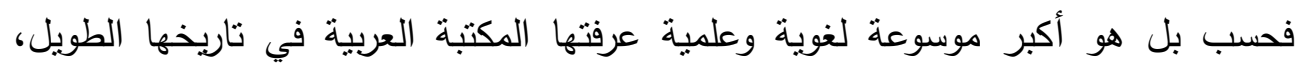

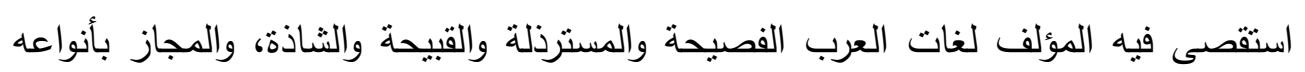

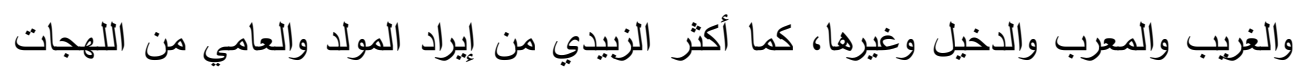

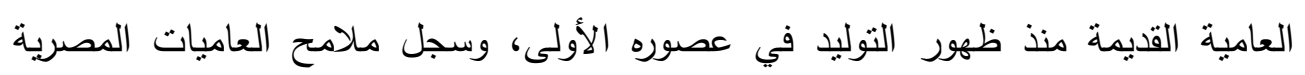

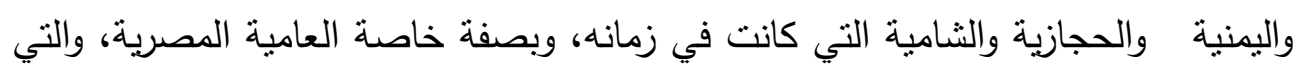

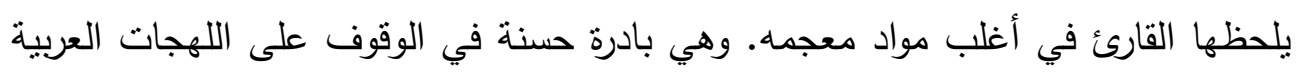

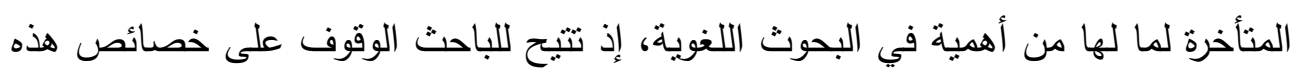

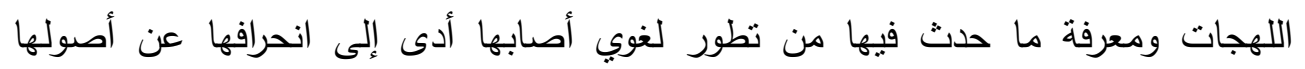
العربية.

وانطلاقا من أن اللهجة الدصرية التي نتكلم بها اليوم هي إحدى اللهجات العربية

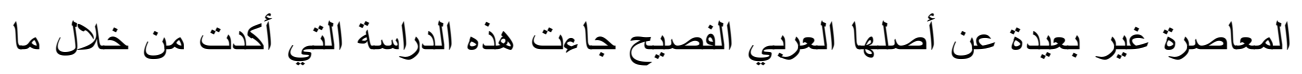

مجلة بحوث كلية الآداب 
د/ مصطفى عبد الهادي عبد الستار محمد

صرح الزبيدي بنسبته تحديدا إلى اللهجة المصرية أو إلى بعض القيد أقاليمها على أن العامية

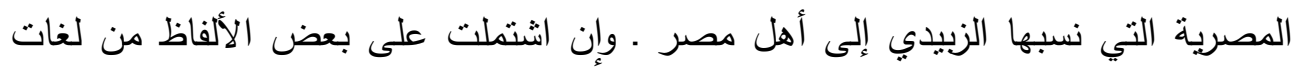
أخرى · ترجع في مجمها إلى أصلها العربي، وأن ثمة انحرافا لغويا جري على ألى ألسنة المصريين "خواصهم وعوامهم" أبعدها قليلا أو كثيرا عن أصلها العربي، وإن بدا بالتأمل اشتراك الألفاظ العامية بمعانيها المستحدثة مع الفصحى في جذورها العربية الأصلية، بل إن إن بهان هناك ألفاظا كثثرة في عاميتتا المصرية لا زلنا إلى الآن نستخدمها بمنطوقها ومعناها العربي الفصيح.

والبحث ليس معنيا برصد اللهجة العامية المصرية بمتتها الثامل في تاج العروس بل

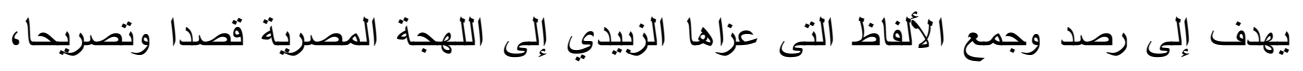
وقد أوردت الدراسة كثيرا من الألفاظ العامية مرتبة على حروف المعجم، تلك التي صرح الزبيدي بعزوها إلى اللهجة المصرية، من خلال ما لاحظه هو بنفسه أثناء تجوله في الديار المصرية، فقد زار كثيرا من مدنها وقراها وكفورها ونجوعها وسمع من المصريين ونقل عنهم

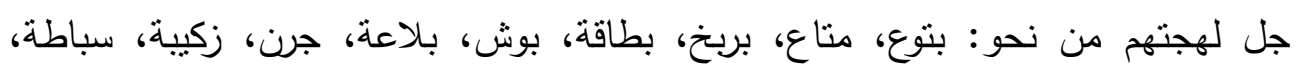

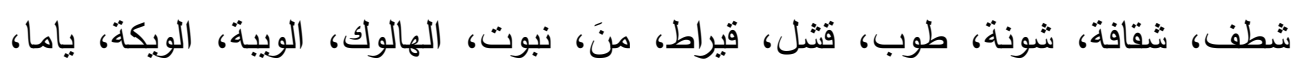

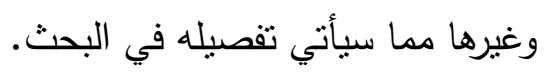
الكلمات المفتاحية: الزبيدي، تاج العروس، الفيروزآبادي، عامية مصرية، لهجة لهية مصرية. 
ما نسبه الزبيدي في تاج العروس إلى اللهجة المصرية

المقدمة

الحمد لله الذي جعل من آياته اختلاف الألسنة واللغات، والصلاة والسلام على خير

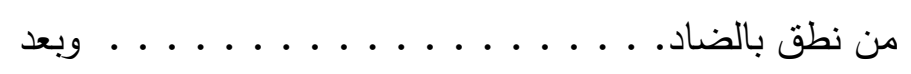

فمعج تاج العروس المسمي( تاج العروس من جواهر القاموس) لمؤلفه الإمام اللغوي

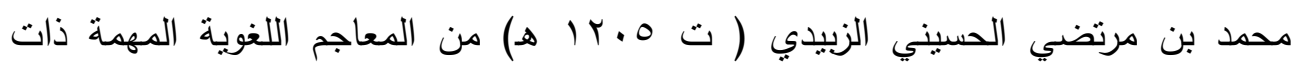

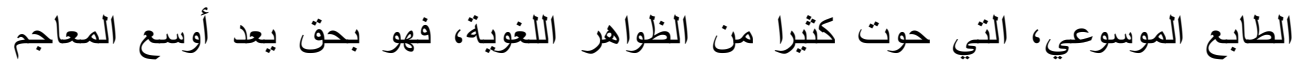

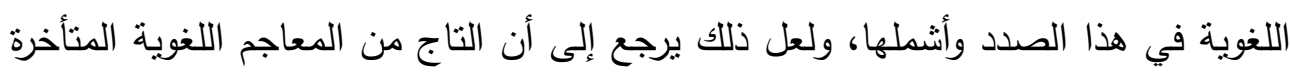

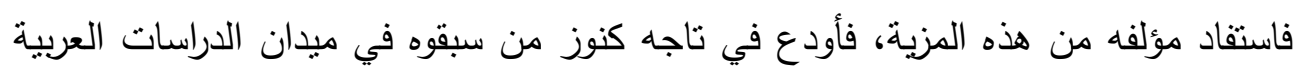

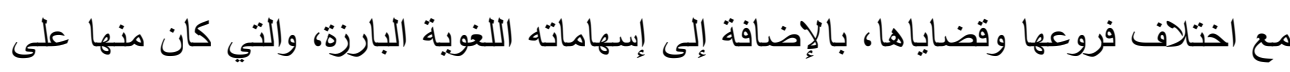

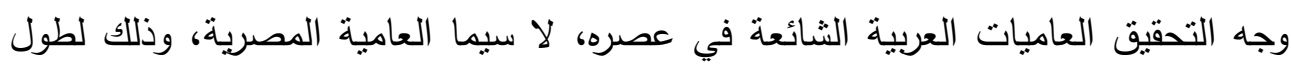

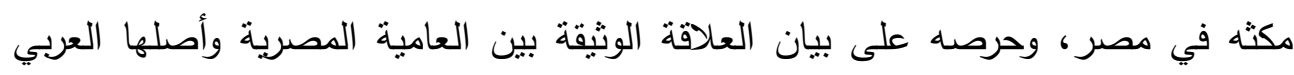

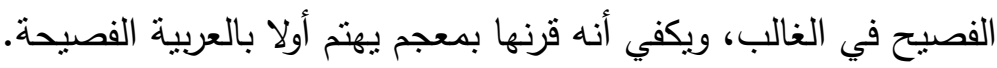

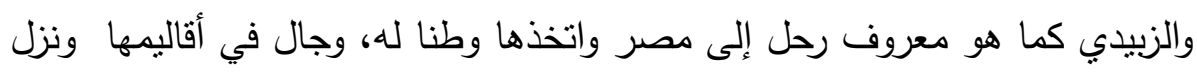

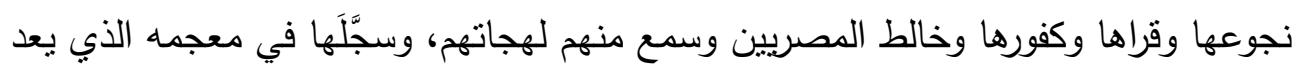

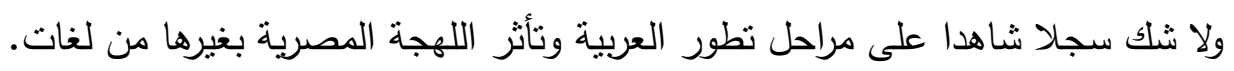

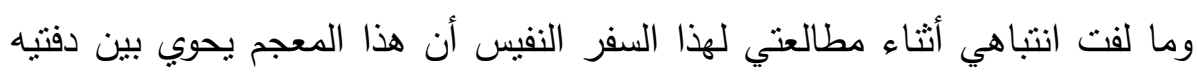

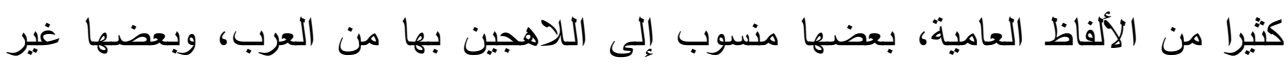

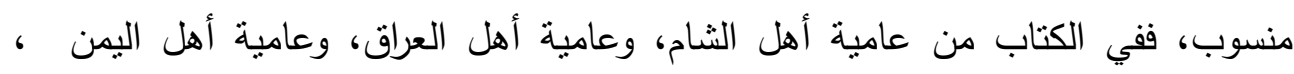

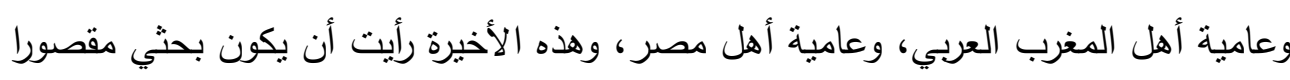

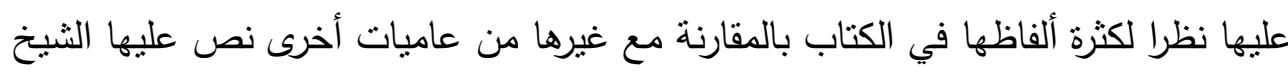

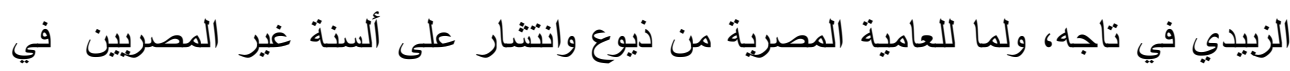
شتَّى الأقطار العربية. ومما ينبغي الإثارة إليه في هذا الصدد أن معجم اللهجة المصرية في معظمه يرجع

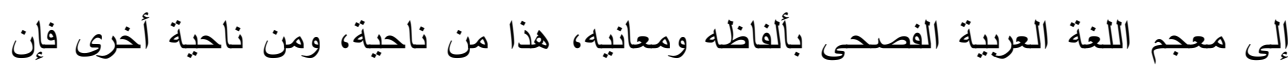

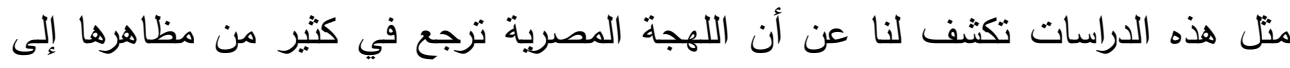




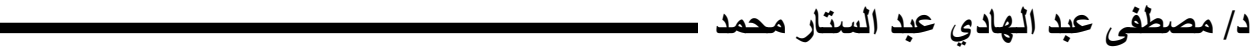
اللهجات العربية القديمة، فإنا نسمع المصريين يقولون: فلان مديون، وهي نرجع إلى لهجة

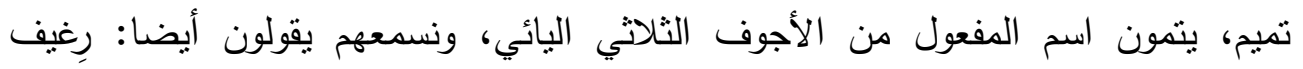

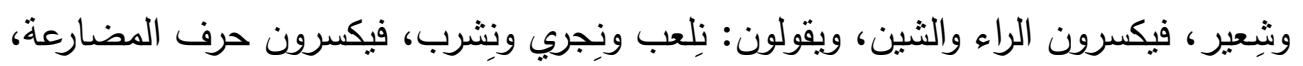
وهي ترجع إلى لهجة تميم والفصحى بالفتح في ذلك. هذا بالإضافة إلى ما تضيفة منّ هذه الدئ والدراسات اللهجية، سواء أكانت في اللهجات العربية القديمة أم في اللهجات العربية المعاصرة إلى العربية الفصحى من ثراء وثروة وقوة، وفي الوقت نفسه تتيح للباحث الوقوف على خصائص اللهجات في شتى مستوياتها الصوتية والصرفية والنحوية والدلالية، والوقوف على مظاهر التطور اللغوي الواقع في العربية من فن فئين

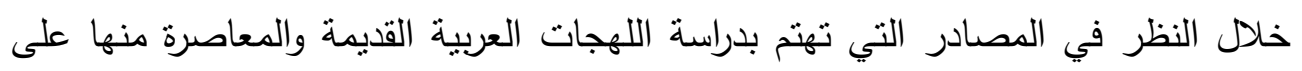
حد سواء، ومعرفة مواضع الضعف والخطأ في نطقها بغية علاجها، كما أن سماع اللهجات المعاصرة وتسجيلها لمعرفة ما حدث فيها من تطور يساعدنا على التقريب بينها وبين اللغة فئه الأم الفصحى وتوحيدها في لغة مشتركة.

وانطلاقا من أن اللهجة المصرية التي نتكلم بها اليوم في مصر ليست لئت بعيدة كل

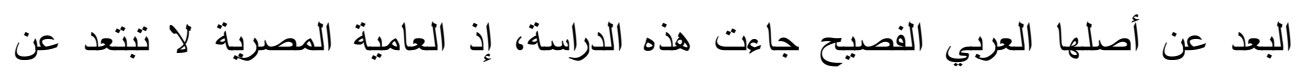
العربية الفصيحة إلا في أمرين: الأمر الأول: الإعراب والذي يعرف بالإفصاح عن المعاني بتغيير أواخر الكلم، وهو

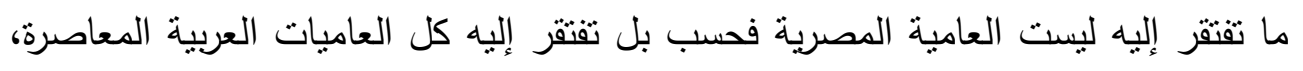
بل إن هذا الأمر ليكاد أن يكون مستحيلا بخصوص هذه العاميات، لأن اللغة أو اللهجة

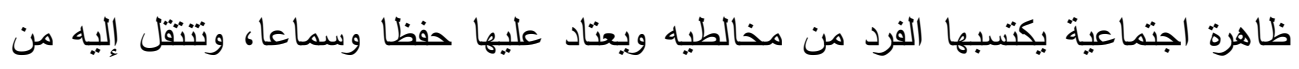

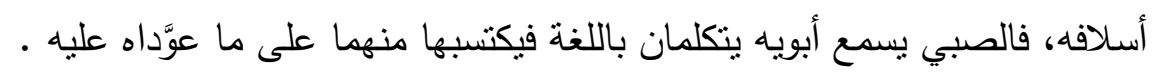
وأما الأمر الآخر: فيتعلق بالجانب الصوتي، فأكثر أصوات اللهجة المصرية وإن كان إن إنهان قد أصابها بعض التطور والانحراف عن أصلها الفصيح إلا أنها في مجملها لا تبتعد كثيرا

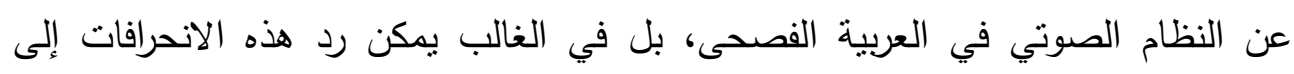
جذورها العربية الأصيلة والوقوف على ما طرأ عليها من تطور وتبدل. ولغوينا الزبيدي في تاجه أحيانا ينص على عزو بعض هذه الصورة الصور (النطقية) اللهجية

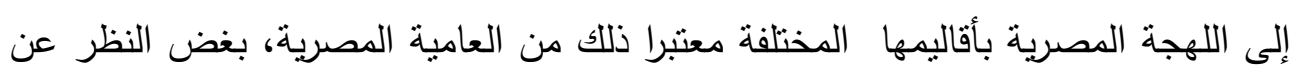




\section{ما نسبه الزبيدي في تاج العروس إلى اللهجة المصرية}

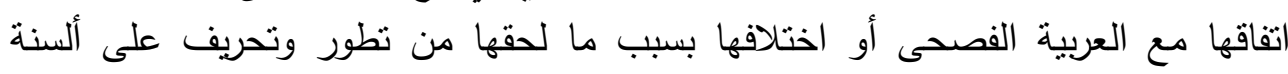

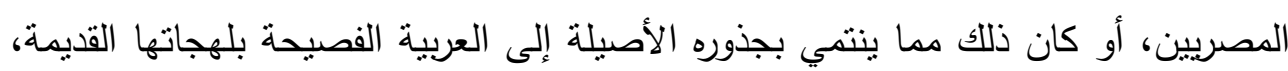

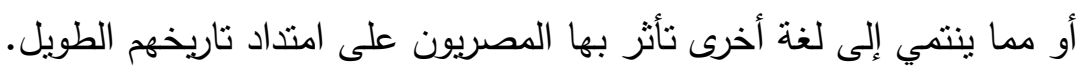

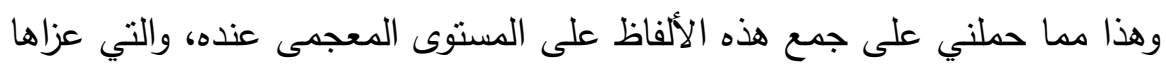

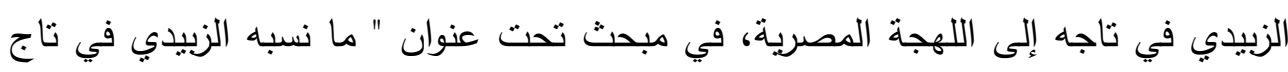
العروس إلى اللهجة المصرية جمعا ودراسة" والقيام بدراستها دراسة وصفية تحليلية بغية ردّّها

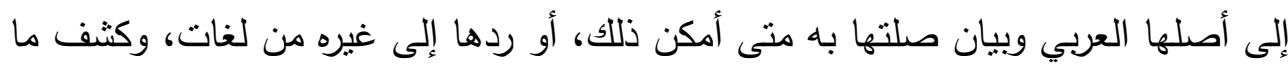
طرأ عليها من تطور أو تحريف أصاب أصواتها أو بنيتها أو دلالتها.

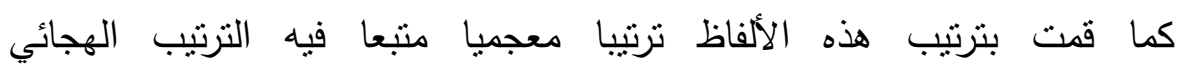

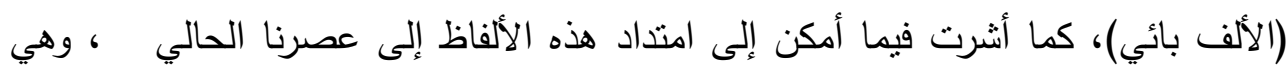

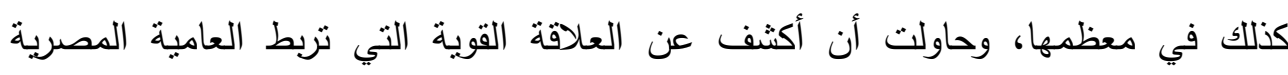

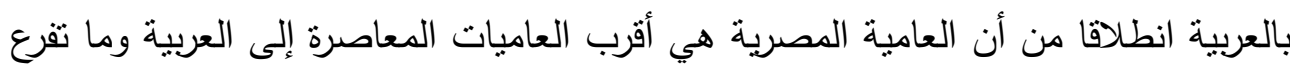
عنها من لهجات قديمة. وقد سبقت هذه الدراسة مقدمة وتمهيد، فأما المقدمة فقد بينت فيها أهمية هذا الموضوع

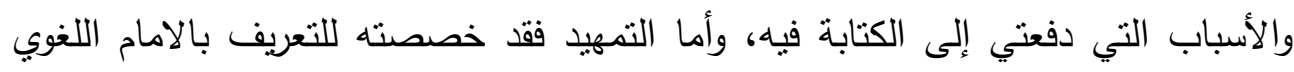
الزبيدي.

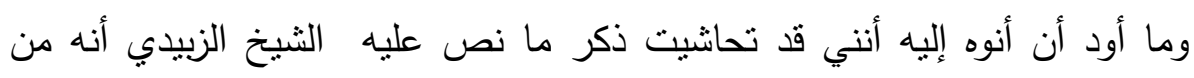

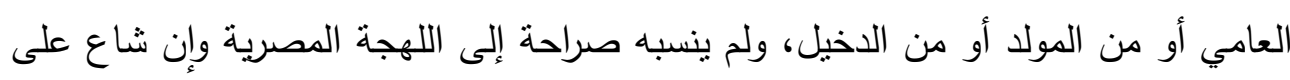

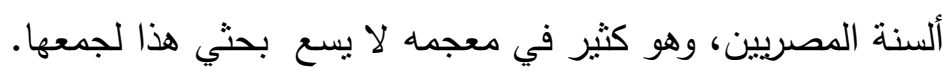

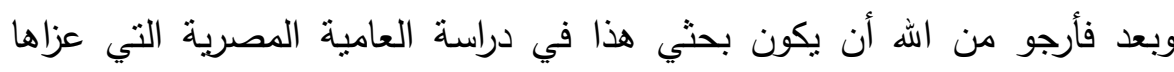

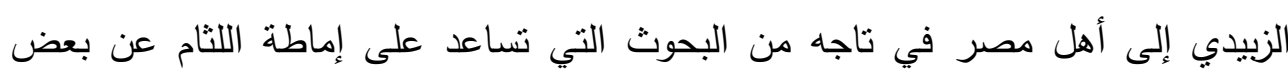

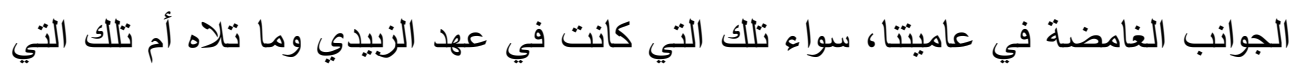

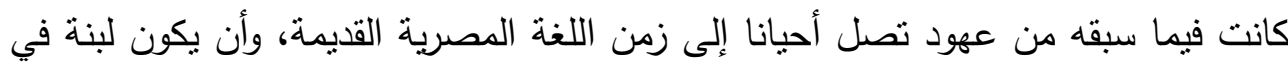

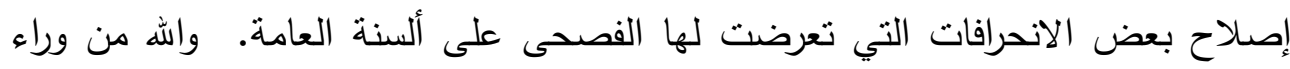
القصد، هو حسبي ونعم المعين.

\footnotetext{
مجلة بحوث كلية الآداب
} 
د/ مصطفى عبد الهادي عبد الستار محمد

\section{تمهـيد}

\section{الزَّبيدي ( مولده وحياته وشيوخه وآثناره ومنهجه )}

التعريف بالزَّبيدي ( اسمه ونسبه ولقبه وكنيته وحياته ):

الزَّبيدي علامة عصره في اللغة والحديث وعلم الرجال والأنساب والتصوف هو : أبو

الفيض محمد بن محمد بن محمد بن عبدالرازق الحسيني الحنفي الواسطي الزبيدي اليمني المصري، نزيل مصر ، الصوفي الثهير بالمرتضى، المكني بأبي الفيض، وأبي الجود، وأبي الوقت، وقد صرح هو بذللك في نسبه، في مقدمة معجم شيوخه الصغير، وفي تاج العروس

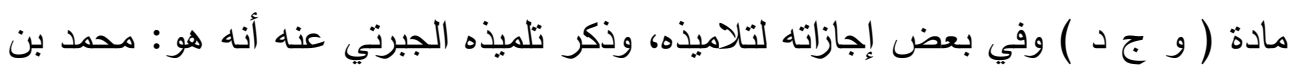
محمد بن محمد بن عبدالرازق الثهير بمرتضى الحسيني الزبيدي الحنفي، هكذا ذكر عن نفسه ونسبه.

أصله من واسط في العراق، ولد سنة عـا 11 هـ، وكان مولده في "بلجارم"( ') من بلاد الهند، هاجر إليها أحد أجداده "أبو الفرج" من العراق عقب غزو هولاكو بغداد، وكان منشأه في زبيد باليمن، رحل إليها وفيها نشأ فنسب إليه، ولم يسنقر المقام فيها فرحل في طلب العلم إلى الحجاز والثام والهند، ثم طاب له المقام في مصر المحروسة، فانتتهر فضله وعرفت مكانته، وتوافد عليه طلاب العلم من كل مكان، وانهالت عليه الهدايا والتحف، وكاتبه ملوك الحجاز والهند واليمن والثام والعراق والمغرب الأقصى والترك والسودان والجزائر ( (). تلقى الزَّبيدي كثيرا من من معارفه في علوم الحديث واللغة والفقه في زبيد حيث نشأ

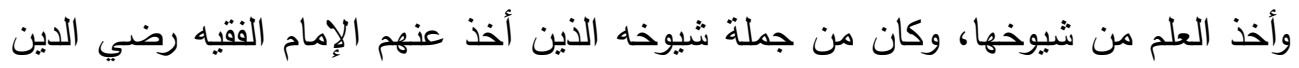
عبدالخالق المزجاجي، سمع منه الصحيحين، وسنن النسائي، وفي ريعان شبابه سافر إلى

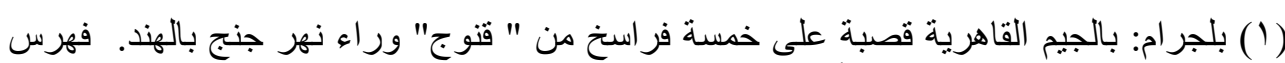

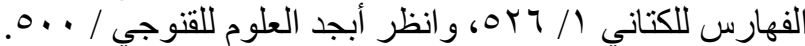

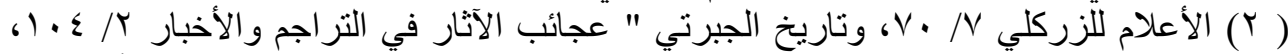

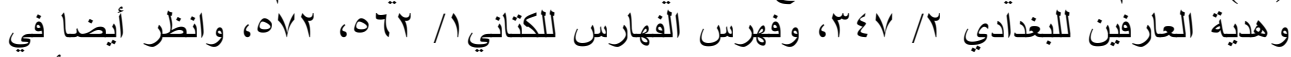

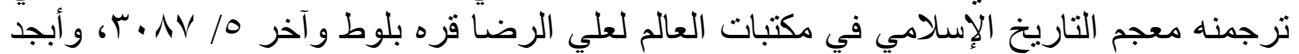

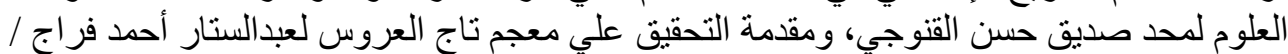

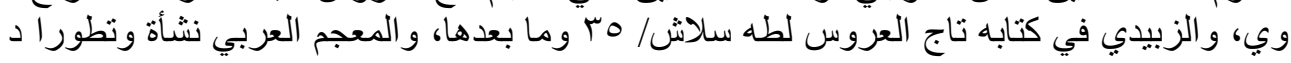

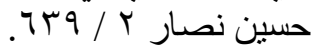

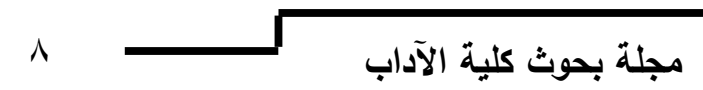


ما نسبه الزبيدي في تاج العروس إلى اللهجة المصرية

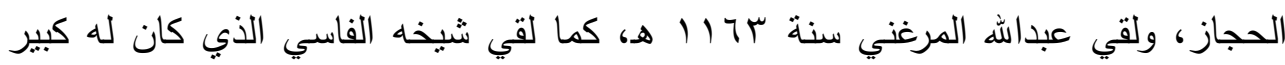
الأثز في توجيهه نحو اللغة، إذ اعتمد على كتابه "إضاءة الراموس وإفاضة الناموس على هلى إضاءة القاموس" في شرحه على القاموس المحيط. يقول هو عنه في مقدمته على تاج

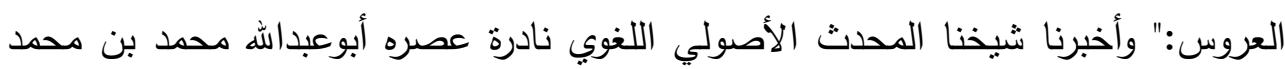
بن محمد بن موسى الشرفي الفاسي نزيل طيية طاب ثراه فيما قرئ عليه في مواضع

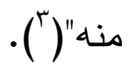

وفي زبيد أخذ عن شيخه المزجاجي قال: "حدثنا شَيخنَا الإمام الْفقيه اللَّنَوِيّ رضيّ

الدّين عبد الْخالق بن أبي بكر الزين ابْن النمري المزجاجي الزَّبِيدي الْحَنَِيّ، وَذلك بمدِينة

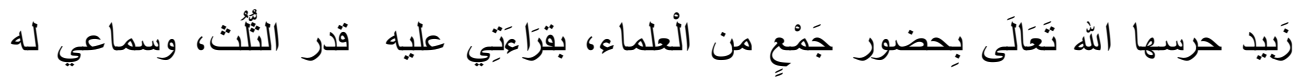

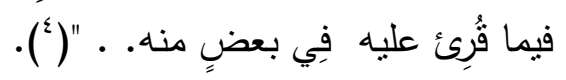

كما أخذ العلم عن الثيخ عبدالرحمن العيدروس ولازمه ملازمة كلية وأجازه بمروياته ومسموعاته، وهو الذي شوقه إلى دخول مصر ـ قال الزبيدي:" وهو الذي شوقني إلى دخول مصر بما وصفه لي من علمائها وأمرائها وأدبائها، وما فيها من المشاهد الكرام فاشتاقت

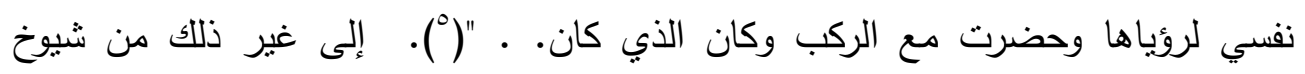

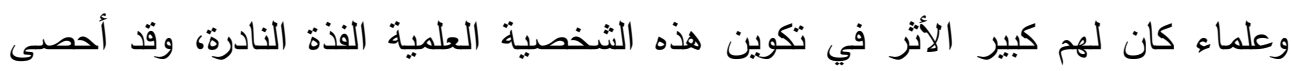
الدكتور هاشم طه شلاش(") في كتابة "الزبيدي في كتابه تاج العروس" ما يزيد عن المئة والسبعين من شيوخ الزبيدي الذين أخذ عنهم العلم، وقد صنفهم وفق أوطانهم، فمنهم اليمنيون، والهنود و والعراقيون والحجازيون والثشاميون والمغاربة والمصريون وغيرهم، والزبيدي

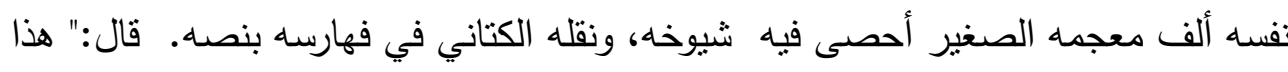
برنامج شيوخي الذين لقيتهم في سياحتي وأسفاري مرتباً لهم على حروف المعجم، ثم أتبعهم بذكر شيوخ الإجازة ثم بما لي من المؤلفات".

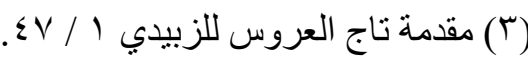

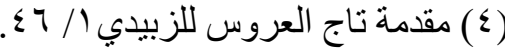

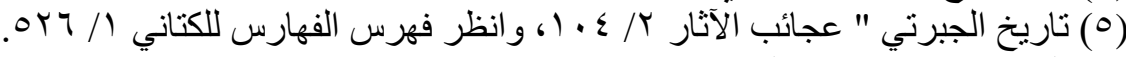

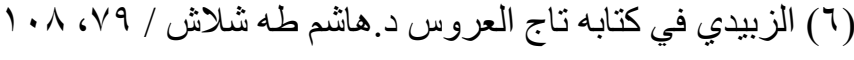




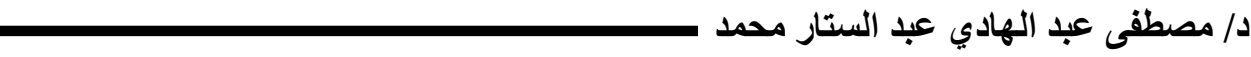
وقد كان تلاميذه الذين أخذوا عنه من الكثرة بمكان ككثرة شيوخه، منهم: الثيخ الثنواني وعلى الونائي، والثهاب أحمد الدمهوجي، والثهاب أحمد السجاعي، والثيخ مصطفي الدهني، وغيرهم(|)، وأثهر تلاميذه على الإطلاق عبدالرحمن بن حسن الجبرتي المؤرخ المصري المشهور، وقد ترجم في تاربخه لأستاذه ترجمة ضافية وافية تذل على مدى محبة واعجاب التلميذ بأستاذه.

ولما ورد الثيخ الزبيدي مصر اتخذها وطنا له فعاش فيها بقية عمره آخذا عن علمائها وشيوخها منتقلا بين مدنها وقراها وكفورها في الصعيد وفي الوجه البحري على السواء، ولا شك أن في جولاته هذه داخل القطر المصري سمع اللهجة المصرية من أهلها المصريين مخالطة ومشافهة مما يفسر لنا اهتمامه بها على وجه الخصوص وتدوين كثير من ألفاظها في معجمه تصريحا أو إثارة وتلميحا. ونظرا لغزارة علم الثيخ وتبحره وسعة اطلاعه أذن له في التدريس بالقاهرة، فدرس الحديث في مسجد شيخون بالصليبية، وسعى إلى استماع دروسه كثير من علماء الأزهر، وكان قد انتقل إلى منزله الجديد بسوبقة اللَّلا فأقبل عليه الأكابر والأعيان ورغبوا في معاشرته إذ كان بشوشا بسوما وقورا محتشما مستحضرا للنوادر والمناسبات ذكيا فطنا واسع الحفظ عارفا باللغة التركية والفارسية والأردية، وازدات شهرته وأقبل الناس من كل ناحية لسماعه ومشاهدته، ودعاه كثير من الأعيان إلى بيوتهم، وعملوا له الولائم الفاخرة. وأقد أثني عليه العلماء بما هو أهل له واعترفوا بفضله وسبقه حتى توافد عليه علماء الأزهر وشيوخه ينهلون من معين علمه الذي لا ينضب، فما قيل فيه: هذا الرجل كان نادرة الدنيا في عصره ومصره، ولم يأت بعد الحافظ ابن حجر وتلامبذه أعظم منه اطلاعاً ولا أوسع رواية ولا أعظم شهرة ولا أكثر منه علماً بهذه الصناعة الحديثية وما إليها، كاتب أهل الأقطار البعيدة بفاس وتونس والثام والعراق واليمن وكاتبوه، وكان الناس برحلون إلبه وبكاتبونه لتحرير أنسابهم وتصحيحها من المشرق والمغرب، وبظهر من ترجمته وآثاره أن هذه الثعلة الضئيلة من علوم الرواية الموجودة الآن في بلاد الإسلام إنما هي مقتبسة من

فهرس الفهارس للكتاني / T Tro (V)

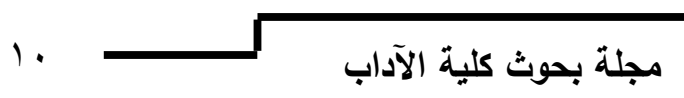


ما نسبه الزبيدي في تاج العروس إلى اللهجة المصرية

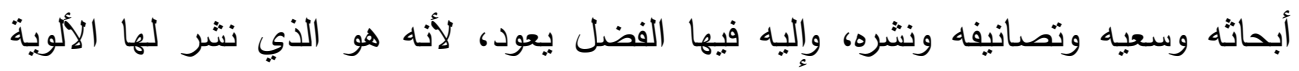

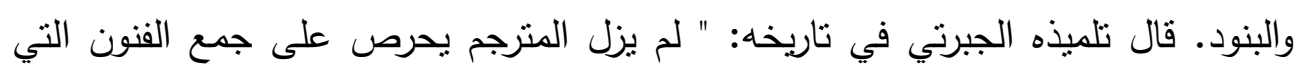

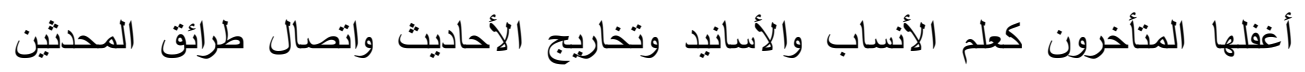

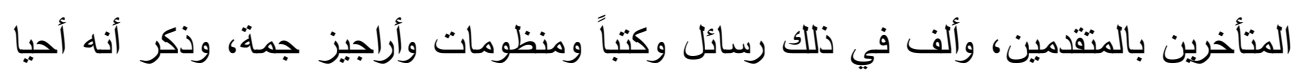

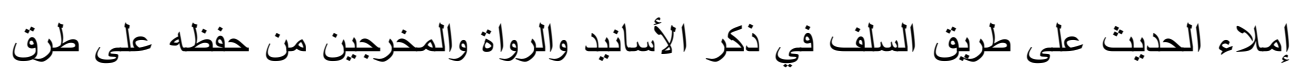
مختلفة، وكل من قدم عليه بملي عليه حيث الأولية برواته ومخرجيه، ويكتب لله سنداً بذللك وإجازة وسماع الحاضرين( أ).

وقال عنه من أعلام الدغرب الحافظ ابن عبد السلام الناصري في رحلته لما ترجمه

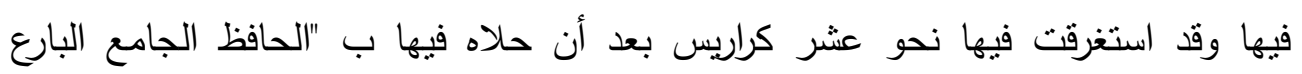

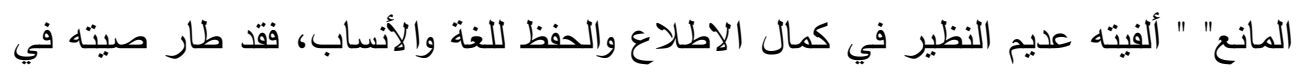

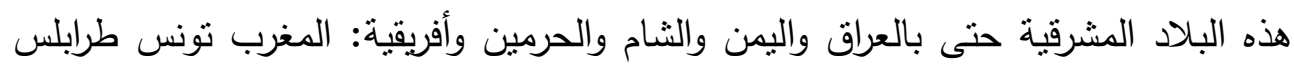

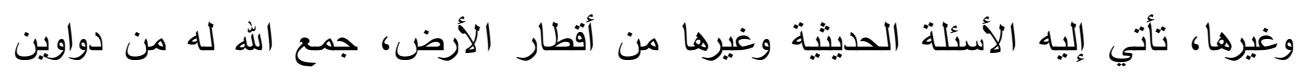

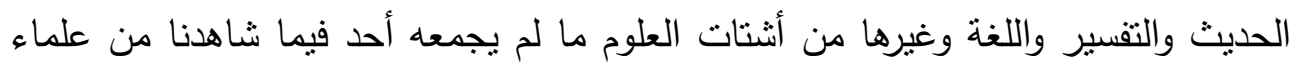

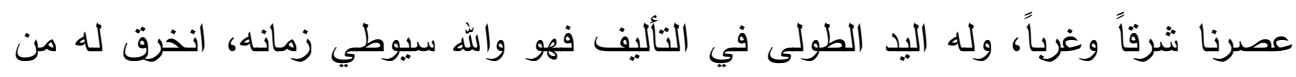

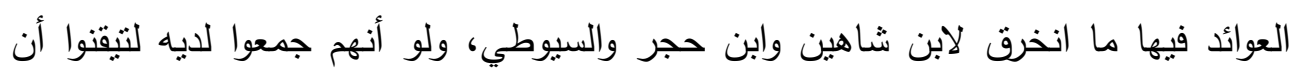

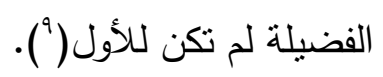
وفي عام 0. أهـ انتشر الطاعون بمصر، فأصيب به الزبيدي بعد صلاة الجمعة

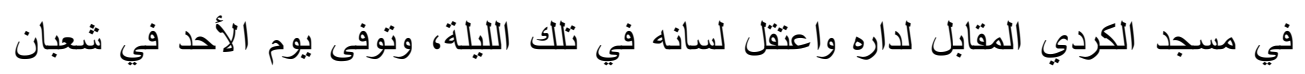

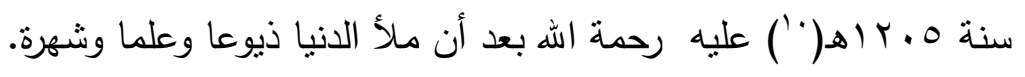

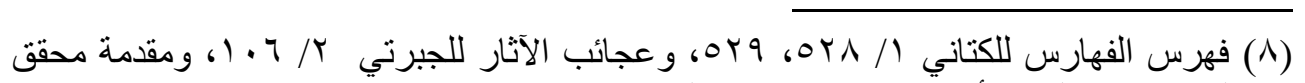

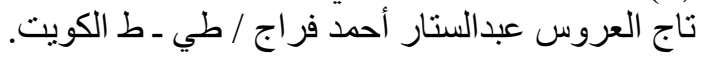

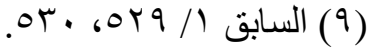

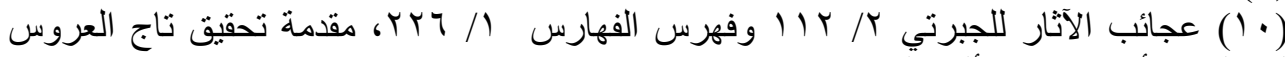
لعبدالستار أحمد فر اج / ألك، بلك. 


\section{د/ مصطفى عبد الهادي عبد الستار محمد آثاره العلمية: مصطية}

الإمام الزبيدي يُعدّ من كبار المصنفين، فقد خلف وراءه للمكتبة العربية والإسلامية ما يزبد عن مائة مؤلف في اللغة والتفسير والحديث والفقه والتصوف والتاريخ وعلم الرجال والأنساب وغيرها، ولو لم يترك من أثز لله إلا هذه الموسوعة العلمية الجليلة "تاج العروس" مولي لكفته فخرا وشرفا وذكرا وتيها بين أقرانه، فالزبيدي بحق يعد من "أعظم العلماء واللغوبين

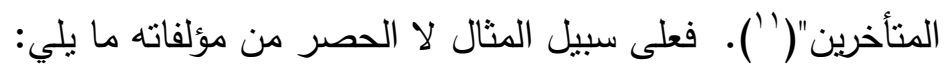
في اللغة: ـ تاج العروس من جواهر القاموس، شرح فيه الزبيدي القاموس المحيط للفيروزآبادي، وسيأتي الحديث عنه.

ـ التكملة والذيل والصلة لما فات صاحب القاموس من اللغة. ـ رسالة في تحقيق لفظ التابوت أسماها" القول المثبوت في تحقيق لفظ التابوت. - رسالة في تحقيق لفظ الإجازة. في الكتابة والخط : ـ حكمة الأشراق إلى كتاب الآفاق.

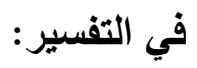

ـ تقسيرعلى سورة بونس على لسان القوم.

ـ الفيوضات العلية في سورة الرحمن من أسرار الصيغة الإلهية.

$$
\text { في الحديث: }
$$

ـ أربعون حديثا في الرحمة.

ـ الأزهار المتتاثرة في الأحاديث المتواترة. ـ أسانيد الكتب الستة.

ـ إكليل الجواهر الغالية في رواية الأحاديث العالية. ـ تخريج الأحاديث النووية.

(11) المعجم اللغوي العربي مادة ومنهجا وتاريخا د عبدالمنعم النجار / 7 ب. 
ما نسبه الزبيدي في تاج العروس إلى اللهجة المصرية

$$
\text { - رسالة في أصول الحديث. }
$$

فالقول الصحيح في مراتب التعديل والتجريح.

في الفقه:

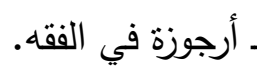

ـ عقد الجواهر المنيفة في أصول مذهب الإمام أبي حنيفة مما وافق فيه الأئمة الستة.

ـ نشوة الارتياح في حقيقة الميسر والقداح.

في التصوف:

ـ إتحاف السادة المنقين بشرح أسرار إحياء علوم الدين، وهو شرح عظيم للزبيدي على إحياء. علوم الدين للإمام الغزالى لا تقل مكانته وأهميته عن تاج العروس، وقد أمضى في تصنيفه أكثر من عشر سنوات، وكان له كبير الأثر في نفس الزبيدي وسلوكه.

$$
\text { ـ شرح صيغة السيد البدوي. }
$$

ـ المقاعد العندية في المشاهد النقتبندية.

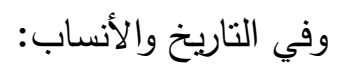

ـ إتحاف سيد الحي بسلاسل بني طي.

ـ تروبح القلوب بذكر ملوك بني أيوب.

- جذوة الاقتباس في نسب بني العباس.

ـ الروض المعطار في نسب السادة آل جعفر الطبار.

إلى غبر ذلك من مؤلفات قام بحصرها من ترجموا للشيخ الزبيدي('r').

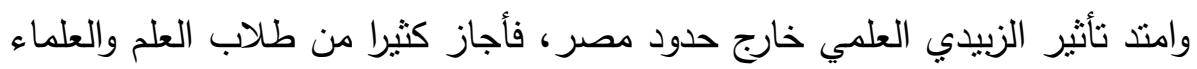

في آن من شتى أرجاء العالم الإسلامي لا سيما بلاد المغرب، فقد امتد تأثنره على علماء

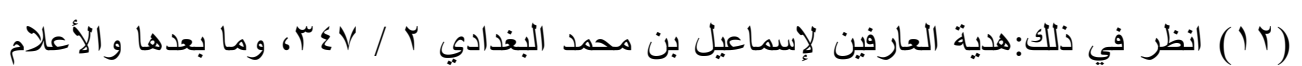

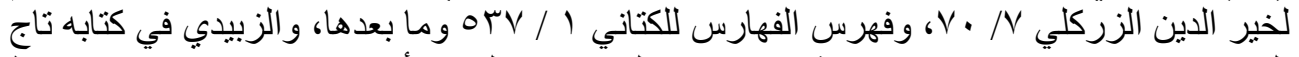

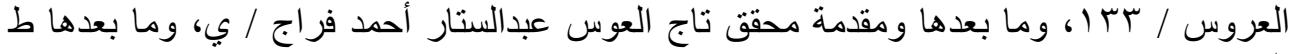

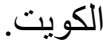

مجلة بحوث كلية الآداب

IT 


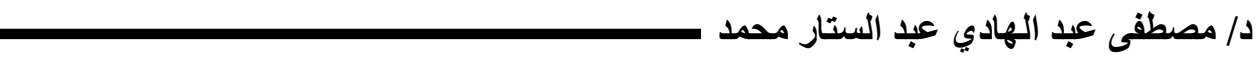

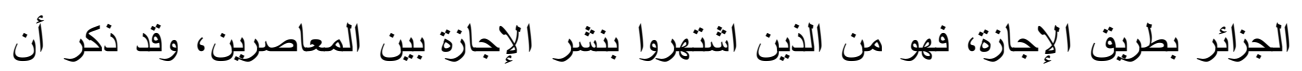
للزبيدي إجازة عامة لأهل قسنطينة تقع في مجلد صغير ، وله أخرى لأهل الراشدية(َّأ).

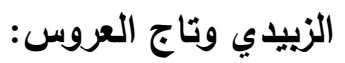
لا يذكر الزبيدي إلا وذكر معه مصنفه الأشهر "تاج العروس من جواهر القاموس"

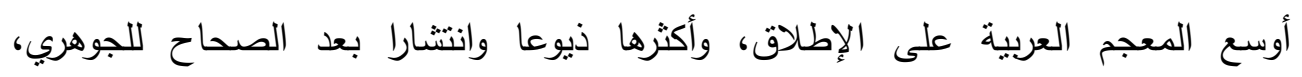
والقاموس المحيط للفيروزآبادي، وتاج العروس شرح على القاموس المحيط للفيروزآبادي، استوعب فيه الزبيدي مادة المعجمات العربية التي سبقته جميعها، وتاج العروس ليس كتاب لغة فحسب بل هو أكبر موسوعة علمية عربية عرفتها المكتبة العربية في تاريخها الطويل،

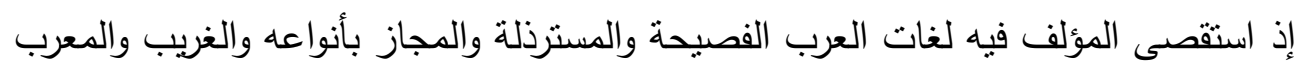
والدخيل ساعده على ذلك إجادته لعدة لغات لفارسية والتركية والأردية، كما أورد المولد

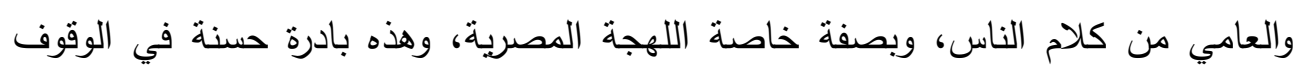
على اللهجات العربية المتأخرة، وإدراك الزبيدي لأهميتها في صناعة المعجم العربي، فضلا عما احتواه معجمه أيضا من مسائل نحوية وصرفية وبلاغية وأخبار أدبية وأعلام الرجال والنساء وأسماء البلدان والمدن والمواضع والحيوان والنبات والأدوية والفوائد الطبية

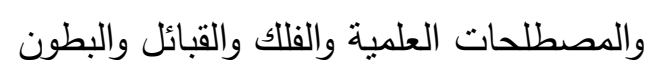
والفرق( 'أ) إلى غير ذلك مما هو مبثوث في معجمه.

وقد ذكر الجبرتي أن شيخه الزبيدي شرع في شرح القاموس حتى أتمَّه في عدة سنين في نحو أربعة عشر مجلدا وسمّاه تاج العروس، ولما أكمله أولم وليمة حافلة جمع فيها طلاب العلم وأثنياخ الوقت بغيط المعدية، وذلك في سنة إحدى وثمانين ومائة وألف وأطلعهم عليه واغتبطوا به وشهدوا بفضله وسعة اطلاعه ورسوخه في علم اللغة وكتبوا عليه

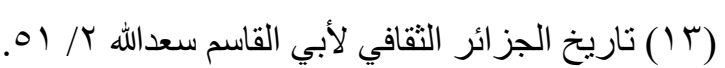

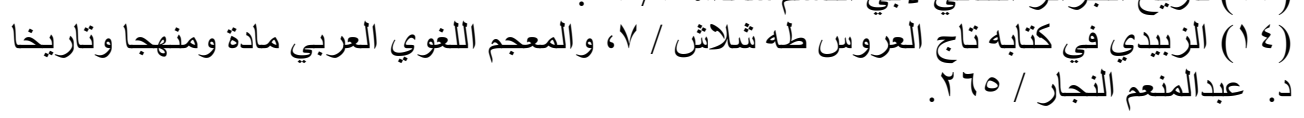


ما نسبه الزبيدي في تاج العروس إلى اللهجة المصرية

تقاريظهم نثرا ونظما(1))، وطار ذكر التاج في الآفاق واشتهر بين الناس كافة، حتى استكتبه ملك الروم نسخة وسلطان دافور نسخة وملك الغرب نسخة، ونسخة منها موجودة في وقف له

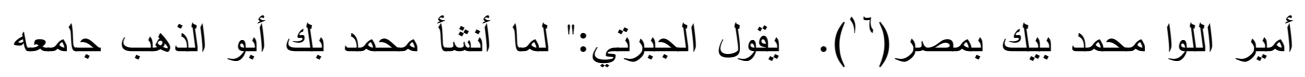
المعروف به بالقرب من الأزهر وعمل فيه خزانة للكتب واشترى جملة من الكتب ووضعها بها أنهوا إليه شرح القاموس هذا وعرفوه أنه إذا وضع بالخزانة كمل نظامها وانفردت بذلك الك

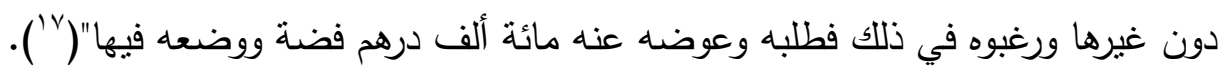
ويرجع السبب الرئيس في تأليف الزبيدي لكتابه " ناج العروس" هو شدة دئ إعجاب الزبيدي بالقاموس المحيط للفيروزآبادي، فنظرا لمكانة القاموس المحيط في نفوس الخاصة من العلماء والعامة على حد سواء وانتشاره في الآفاق أو على حد قول الزبيدي: "ولعَمَرِي

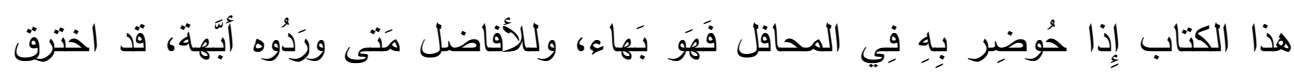

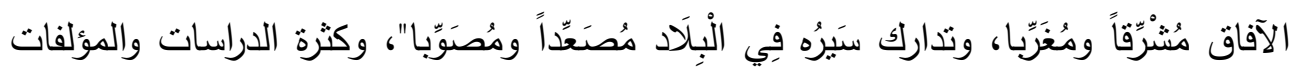
التي قامت عليه استدراكا أو شرحا أو تعليقا، مع شدة إيجازه واختصاره، وغموض إندان ألفاظه

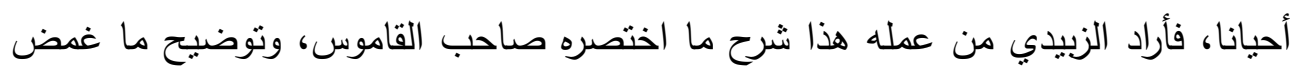
أوالتبس من ألفاظه ومعانيه، وإكمال ما نقص منه، وجمع ما سبقه من شروح وتعليقات واستدراكات في كتاب واحد يعم النفع به، ويغني عنها جميعا( (^ل). منهج الزبيدي في المولد والعامي:

لما كان المولد سببا رئيسا في وجود العاميات جنبا إلى جنب مع الفصحى كان لزاما علينا أن نعرج عليه عند الزبيدي، والمولد ظاهرة لغوية واقعة في جميع اللغات الإنسانية،

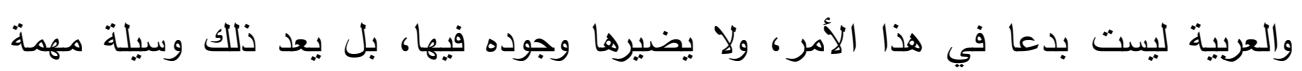

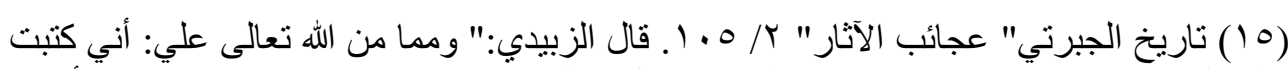

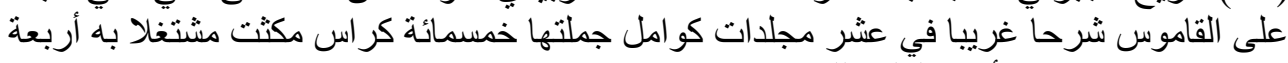

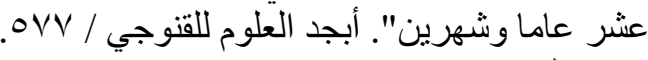

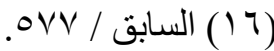

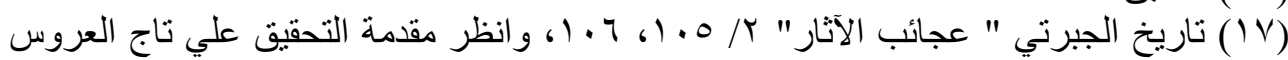
لعبدالستارفر اج/ طارئ طبعة الكويت.

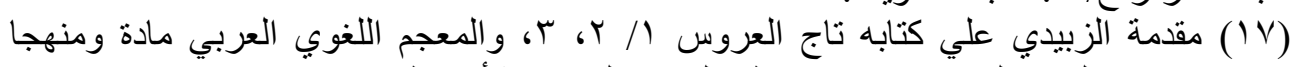

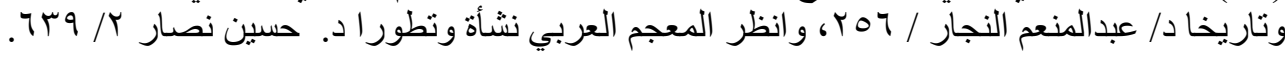


د/ مصطفى عبد الهادي عبد الستار محمد

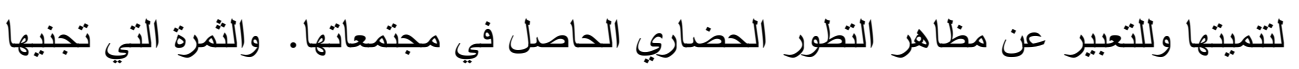
العربية من وجود المولد فيها أن الألفاظ الدخيلة من لغات أجنبية والتي تمنل رصيدا لفظيا مستعملا على ألسنة العامة والخاصة من الناس يحل محلها لفظ عربي جديد اخترعته العامة، أو لفظ عربي أصيل قديم أعيدت إليه الحياة مرة أخرى من خلال إلباسه معنى جديدا

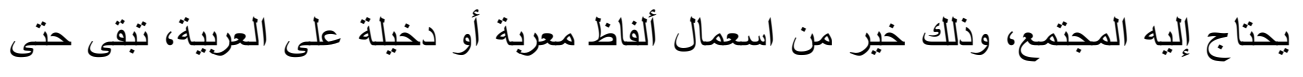

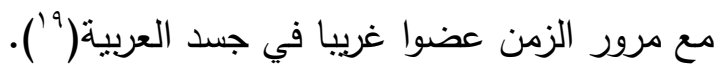

والمولد تعددت تعريفاته عند اللغوبين إلا أنها جميعا تكثف لنا عن أن أن المولد ما ولِّد من كلام العرب، وليس عربيا محضا بل شئ أحدثوه في كلامهم بعد عصور الاحتجاج.

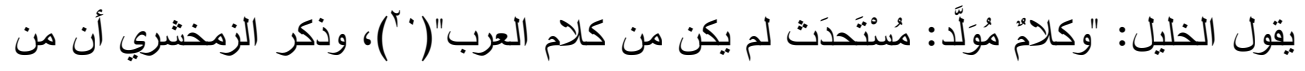

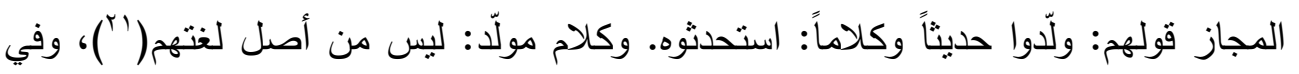

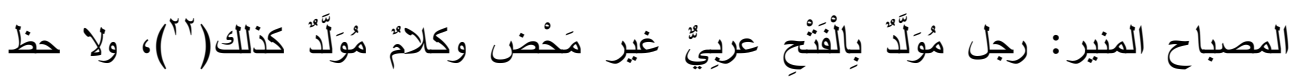

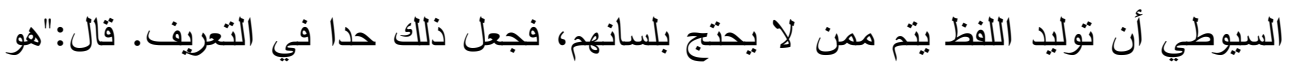
ما أحْدثه المولَّدون الذين لا يُحْتجِ بألفاظهم والفرق بينه وبين المصنوع أن المصنوع يُورده

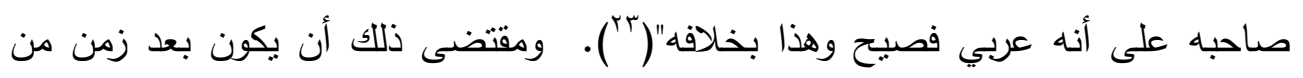

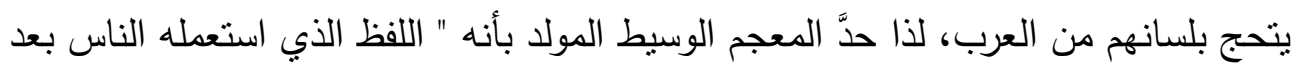
عصر الرواية"( گ؟)، فالناس بعد عصور الاحتجاج سمّاهم اللغويون مولدين وكذا ما يحدثونه

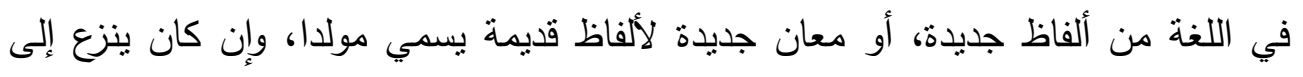
عرقه العربي الصريح إلا أن العامة غيرته بإبدال حرف أو حركة موضع الأصيل، أو بزيادة

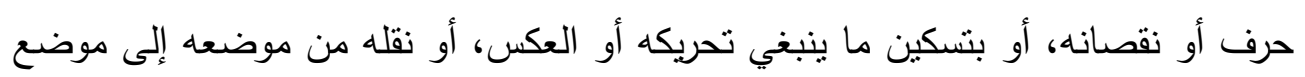

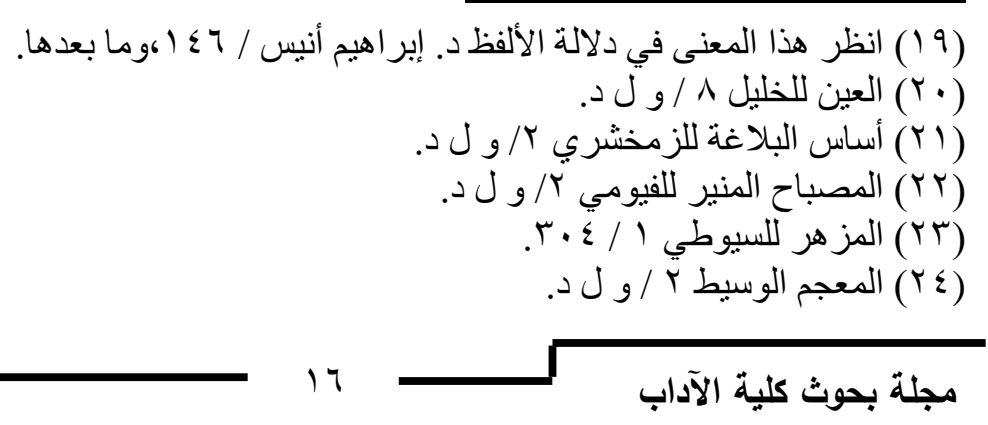


ما نسبه الزبيدي في تاج العروس إلى اللهجة المصرية

آخر من الكلمة، وهذا يعني أن التوليد هو الأساس في نشوء العاميات العربية القديمة فاجية العبدة والمعاصرة( (ro).

وعملية التوليد هذه تأخذ طريقين:

الأول: صوغ كلمات جديدة لا عهد للعربية الفصحى بها، كلفظة" اللادركزية، الماهية،

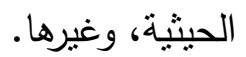

الثاني: إسباغ معنى جديد على لفظ قديم لم يوضع لهذا المعنى لعلاقة ملحوظة بين

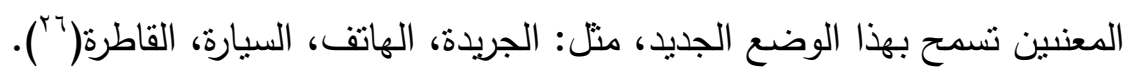
والزبيدي كان على إدراك تام لمفهوم المولد في اللغة وما ينتج عنه من آنار في

اللغة الفصحى، فقد عقد المقصد الثاني لبيان جملة من الموضوعات اللغوية منه المولد، فعرفه اعتمادا على ما نقله عن المزهر، فنقل تعريف السيوطي السابق والفرق بين المولد والمصنوع، وقال أيضا نقلا عن الزبيدي في مختصر العين: "المولد من الكلام

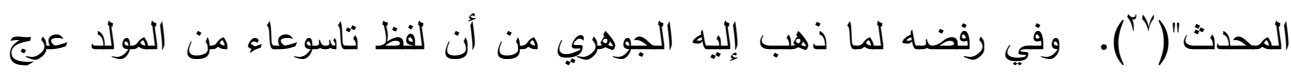
على تعريف المولد، فقال: "المولد هو اللفظ الذي ينطق به غير العرب من المحدثين"( آبه.

العامي نسبة إلى العامة، والعامة خلاف الخاصة( (9)، أي أن العامي ما ذاع وفثشا

على ألسنة الجمهور من الناس، ووتوحي دلالة هذا المصطلح بكونه مبتذلا " ساقطا سوقيا" على حد قول الجاحظ، وهو مرادف للمولد عند بعض اللغوبين كثعلب، والسيوطي الذي ولي استتتج هذا الفهم من كلامه. قال:" في أمالى ثعلب: سُعِلِل عن التغيير : فقال هو كلُ شيء مولد.

$$
\begin{aligned}
& \text { (Y0) انظر هذا المعني في الزبيدي في كتابه تاج العروس / r ـ ـ T. }
\end{aligned}
$$

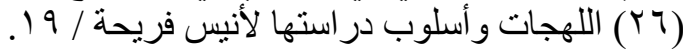

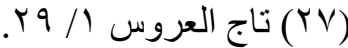

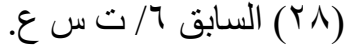

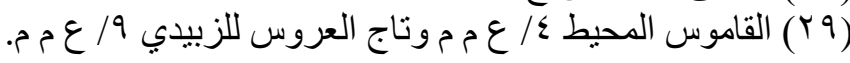


د/ مصطفى عبد الهادي عبد الستار محمد

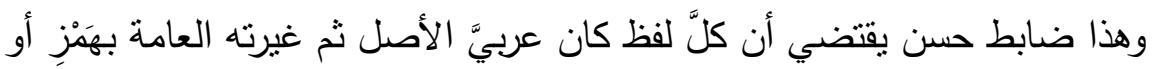

تَزَكه أو تسكينٍ أو تحريك أو نحو ذلك مولد، وهذا يجتمع منه شيء كثير (·r).

ويرجع سبب نشأة اللغة العامية في العصور الأولى إلى كثرة لهجات القبائل،

ومخالطة الأعاجم العرب، إذ تركت هذه المخالطة آثارا غائرة في العربية، فقد تلاعبوا بألفاظها بين حذف وزيادة وقلب وإبدال ونحت وتصحيف وتحريف وتغيير وتبديل وما شابه

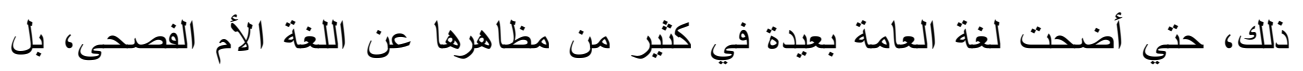
يصعب أحيانا على المختصين رد ألفاظها إلى أصلها أو معرفة مصدرها ومراحل تطورها (")

وتتقسم الكلمات العامية من حيث أصولها، إلى ثلاثة أقسام: قسم عربيّ الأصل، وهو الكثير الغالب. وقسم دخيل، من لغات شتى.

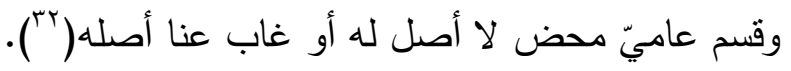

والزبيدي في معجمه "تاج العروس" اهتم بالمولد والعامي اهتماما بلغ فيه النهاية، ولا

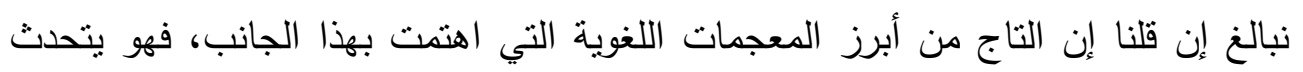
عن اللغات العامية القديمة منذ ظهور التوليد في عصوره الأولي، ويسجل ملامح العاميات الترن المصرية واليمنية والحجازية والثامية التي كانت في زمانه(بَ)، لا سيما العامية المصرية والتي يلحظها القارئ في أغلب مواد معجمه.

وقد اعتمد الزبيدي في نقل المولد والعامي من اللهجات العربية القديمة على أقوال اللغوبين في معاجمهم والتي اهتمت بتسجيل هذه الظاهرة، كالأزهري في التهذيب، والجوهري في الصحاح، وابن منظور في اللسان، والفيروزآبادي في القاموس، والصاغاني في العباب وغيرهم، وهو في هذا الصدد لا يسلم دائما بأحكامهم بل أحينا ما يتعقبهم وينقد أقوالهم، ففي ولي

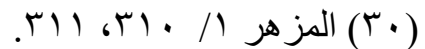

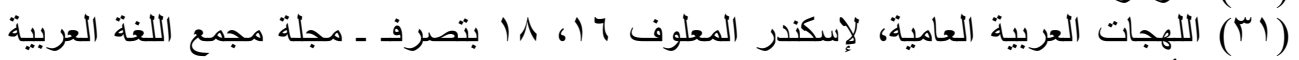
الجزء الأول.

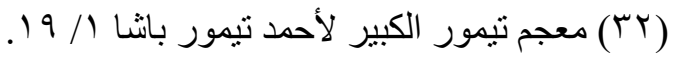

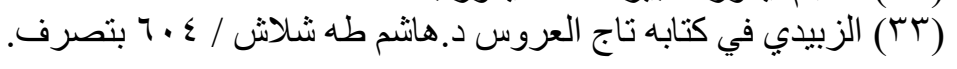


ما نسبه الزبيدي في تاج العروس إلى اللهجة المصرية

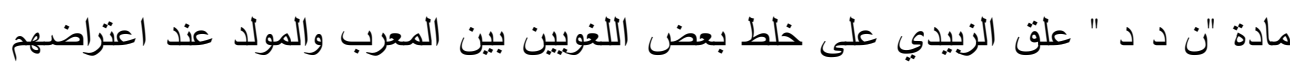

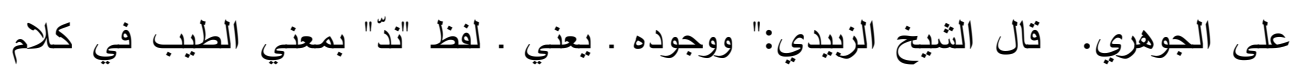

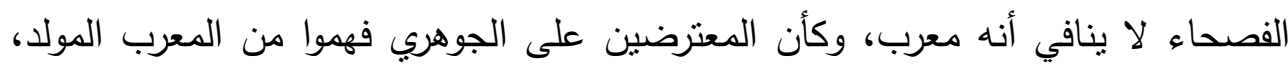

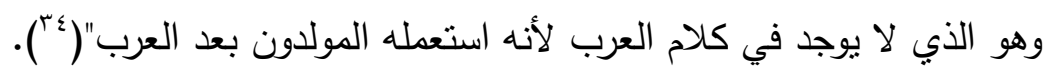

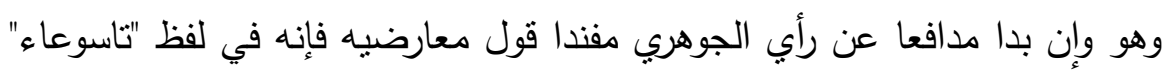

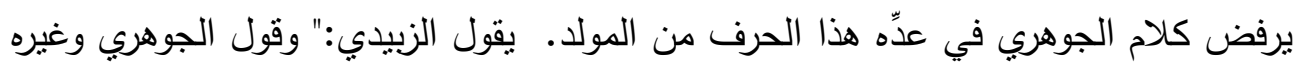
إنه مولد فيه نظر ، فإن المولد هو اللفظ الذي ينطق به غيه غير العرب من المحدثين"، وانطلاقا

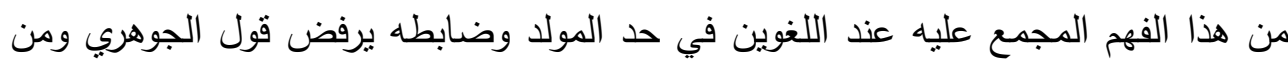

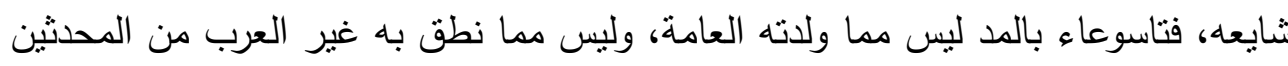

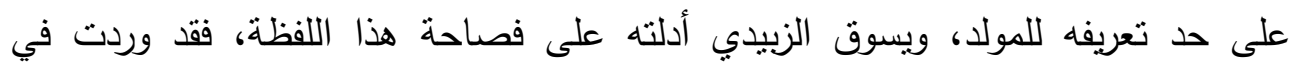

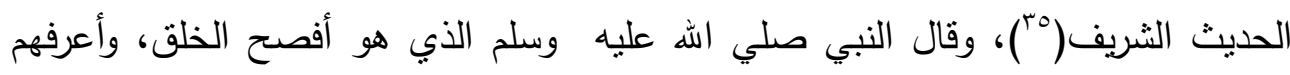

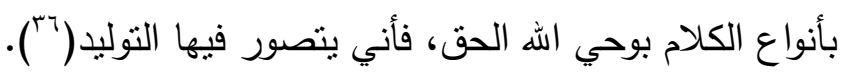
وأحيانا يحاول استقصاء آراء اللغويين بالنقل والتمحيص والموازنة تارة وبالنقد تارة

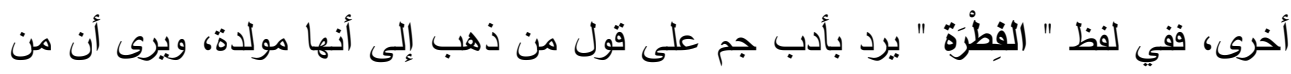

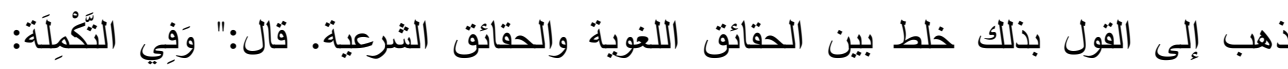

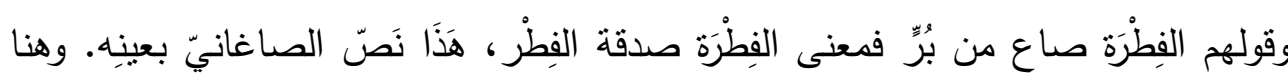

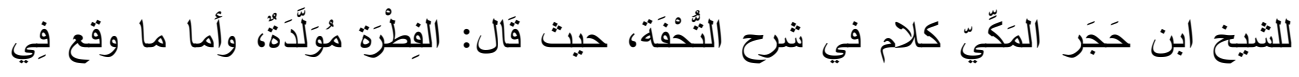

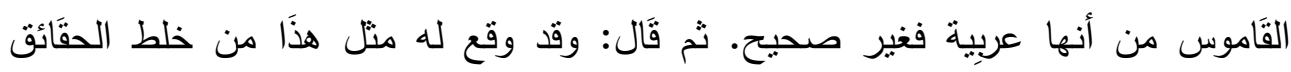

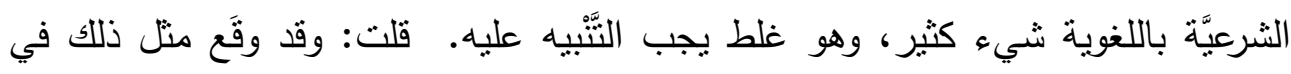

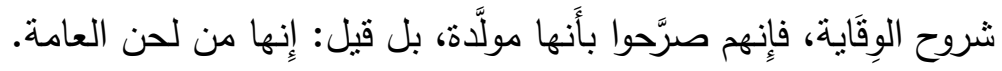

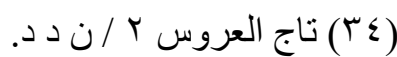

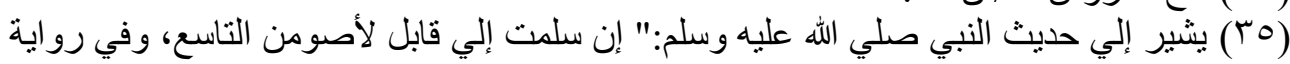

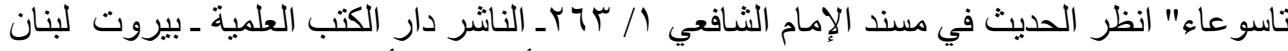

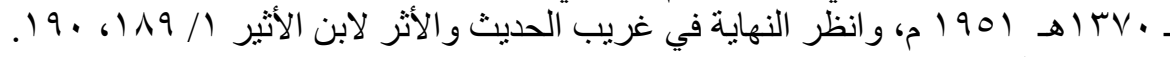

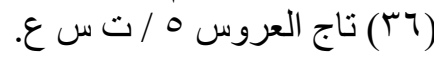




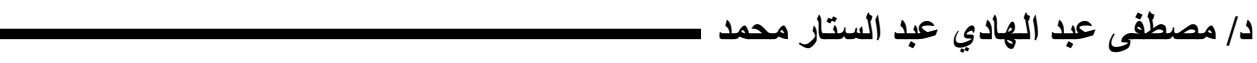

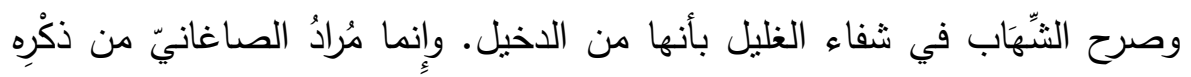

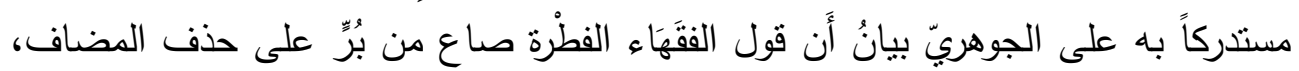

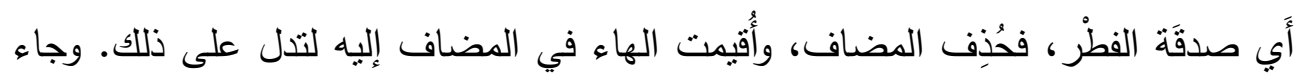

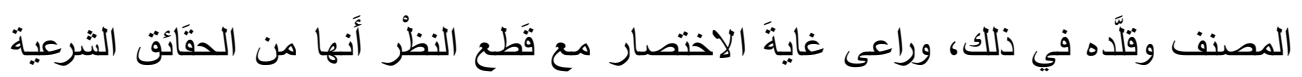

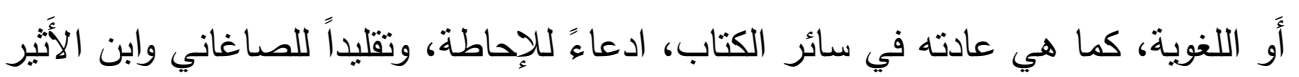

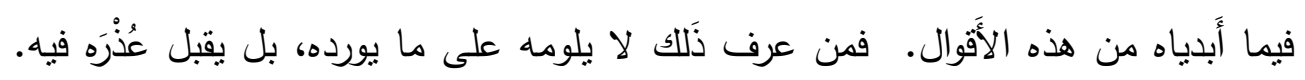

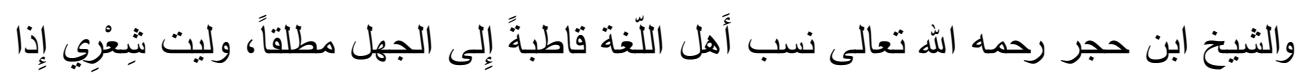

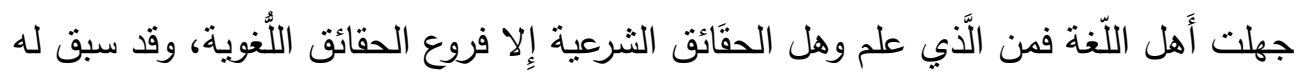

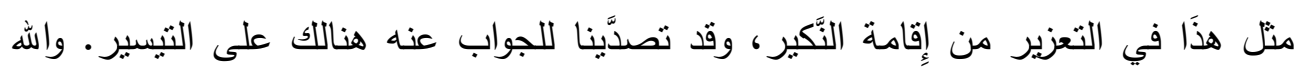

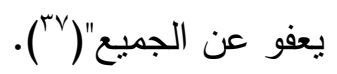

وفي لفظ "القَرْنان" صرح بأنه الديوث المشارك في قرينته لزوجته، وإنما سميت الزوجة قرينة لمقارنة الرجل إياها، وإنما سمي القَرنان لأنه يقرن بها غيره، عربي صريح حكاه كراع.

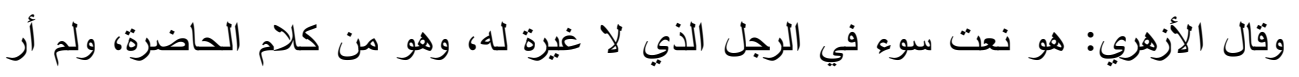

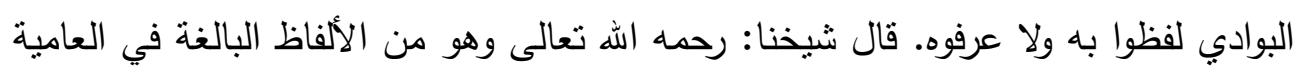
والابتذال، وظاهره أنه بالقتح، وضبطه شراح المختصر الخليلي بالكسر، وهو فوهو فعلال أو أو

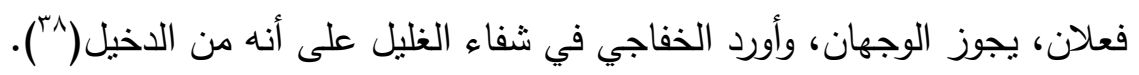

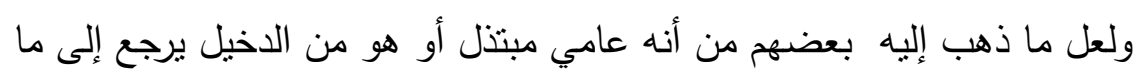

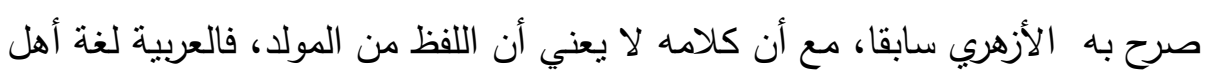

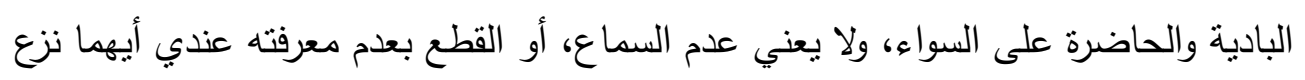
اللفظ من عروبته ورميه بالعامية والابتذال. وفي جمع حاجة على حوائج يعرض لآراء اللغويين فيه وينتصر لفصاحته، فحوائج

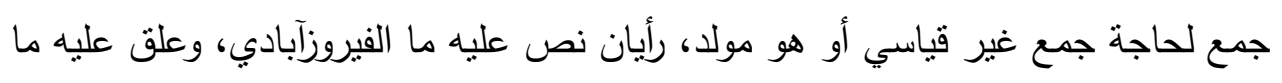
الزبيدي، فالقول غير قياسي قول الأكثرين، لذا أنكر الأصمعي فصاحتهانها فقال فئ إنها مولدة،

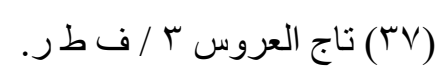

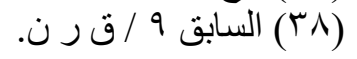

$$
\begin{aligned}
& \text { مجلة بحوث كلية الآداب }
\end{aligned}
$$$$
r .
$$ 
ما نسبه الزبيدي في تاج العروس إلى اللهجة المصرية

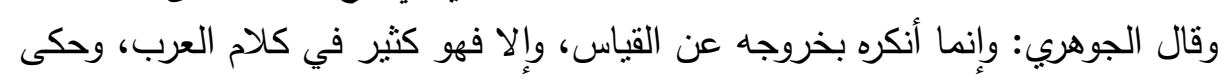
الزبيدي نقلا عن ابن بري احتمال كونهم جمعوه على "حائجة" ولم ينطق به، ثم رد على من ونا

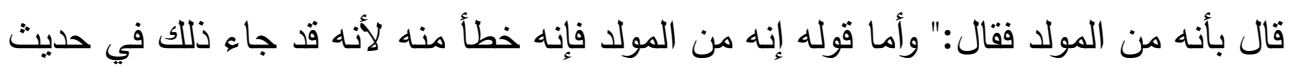
سيدنا رسول الله صلي الله عليه وسلم، وفي أشعار العرب الفصحاء("َّ).

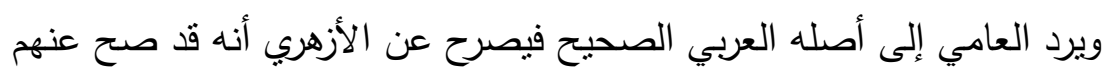

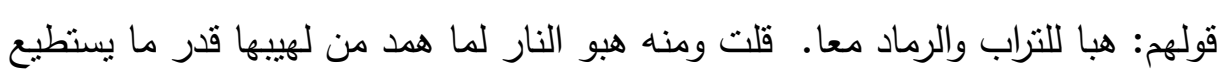

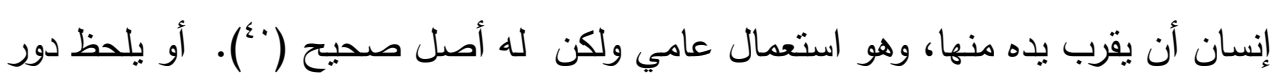
المجاز في نقل اللفظ على ألسنة العامة كما في لفظ البند يطلق على المحابس التي تجعل

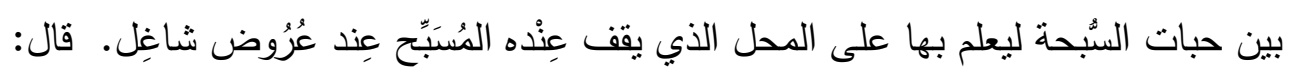

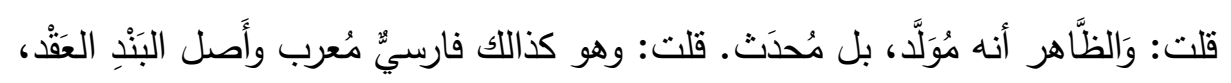

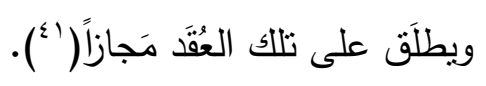
وفي لفظ القحبة ينقل عن الأزهري وغيره علة تسمية الفاجرة البخي بذلك لأنها كانت في الجاهلية تؤذن طلابها بقحابها، وهو سعالها، أي تجعل السعال والتتحنح رمزا وإشارة لطلابها، ولا يفوته أن يعرج على ما قيل فيها من أنها مولدة عن الفيروزآبادي قي قول آخر آنر له، ويذكر أن ذلك مما جزم به الجوهري، ثم يعرج على دور المجاز في تطور هذا اللفظ على ألسنة العامة وإكسابه هذا المعنى حتي صار فيه حقيقة وضعية، فينص عن أبي هلاد

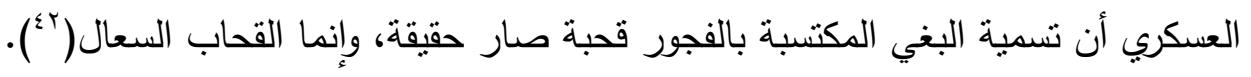

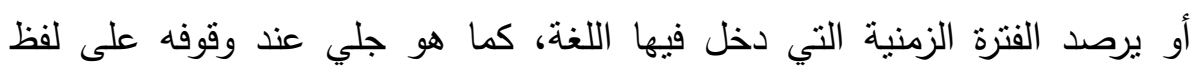

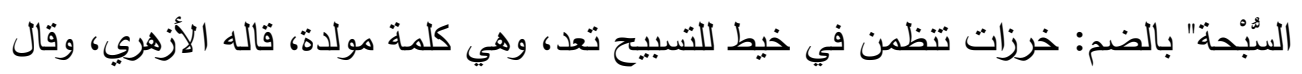

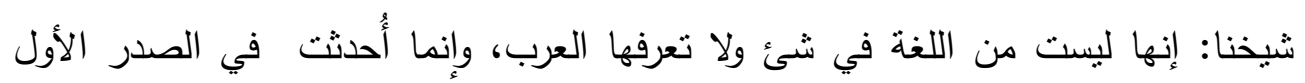
إعانة على الذكر وتذكيرا وتنشيطا (باء).

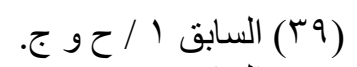

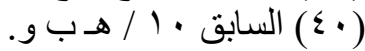

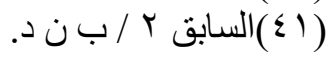

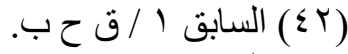

$$
\begin{aligned}
& \text { (r ( }
\end{aligned}
$$


د/ مصطقى عبد الهادي عبد الستار محمد

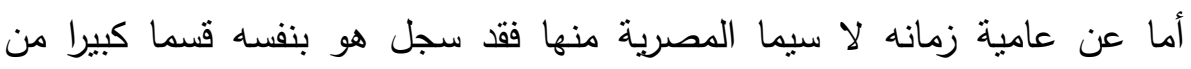
مادتها سماعا ومشافهة، بعد أن جوَّل في البلدان والقري واستمع إلى الناس وهم يتحدثون

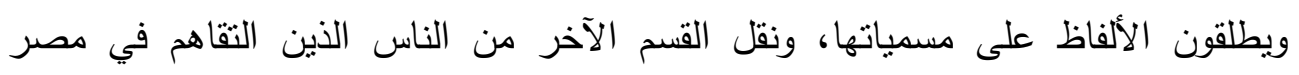

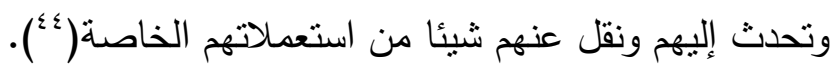
ويلحظ القارئ لمعجمه أن العامية المصرية تحظى بقسط كبير من اهتمام الزبيدي في

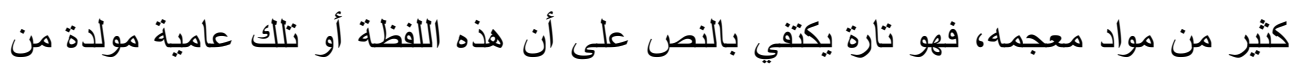
دون عزو ذلك في كثير من الألفاظ، وإما بالنص على أنها مما أحدثه المصريون وولدوه. فمن الأول ما صرح به الزبيدي في لفظ "الزَّلابية" حيث ينقل عن صاحب القاموس المحيط أنها حلواء معروفة، ويزبد في ذلك عن الخفاجي أنها مولدة، وقيل: إنها عربية لورودها في رجز قديم، وقال شيخه فيه نظر . . . . (0؛) وهي بهذا الوصف من عامية أهل مصر م والمُدَّلَّع: كمعظم: المتربي في العز والنعمة مولدة، والاسم الدَّلاعة( بَّ)، وهي مستعملة في اللهجة المصرية بهذا المعنى. والصنيادية: أرز بطبخ بالسمك عامية(" أ)، وفي موضع آخر يصرح بأنها من العامية المصرية، طعام معروف مشهور عند سكان ساحل مصر ، كدمياط ونحوها.

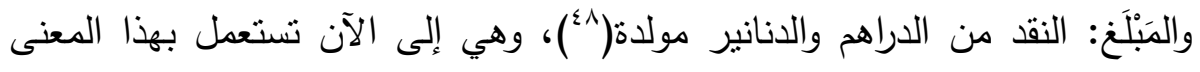
الذي صرح به الثيخ لقدر معين من النقود. ويلحظ أحيانا ما بطرأ على اللفظ في اللغة العامية وإن لم يستبعد أصالته العربية، فالمُزَوَّق: المزين بالزئبق، ثم كثر حتي سمي كل شئ مزين مزوقا، ثم يعقب على ذلك بقوله:

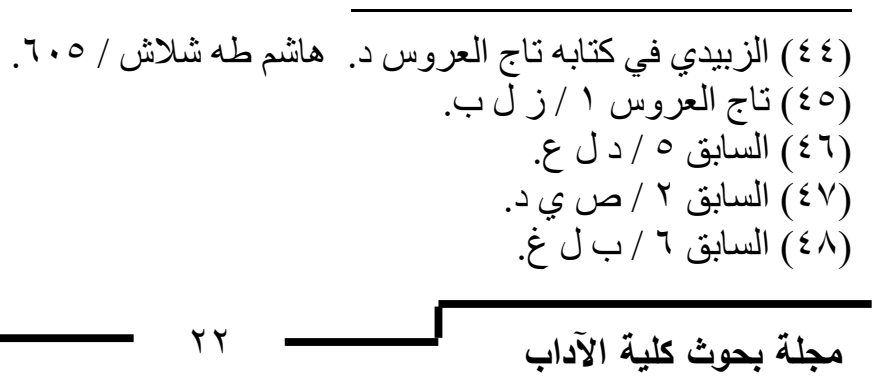


ما نسبه الزبيدي في تاج العروس إلى اللهجة المصرية

قال شيخنا: فهو إذن عربي صحيح وليس خطأ كما توهمه البعض، لكنه عامي مبتذل كما فال نبه عليه في شفاء الغليل(

والقَبَقاب: النعل من خشب، وزياءة على على ما ذكره فيها من أنه في لغة اليمن صرح بأنه

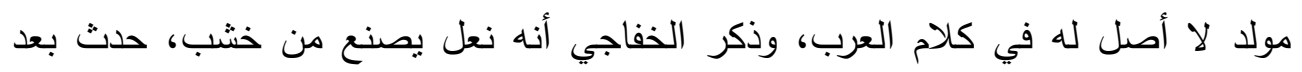

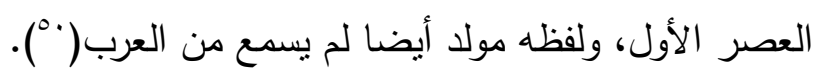

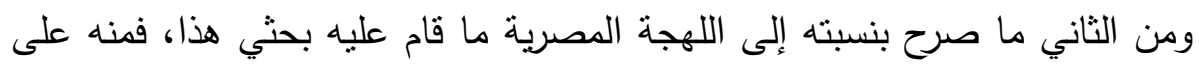

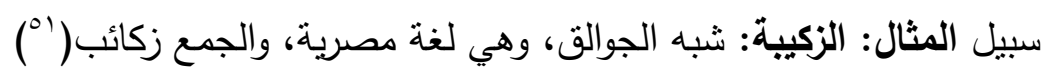
النبوت: الفرع النابت، وبطلق على المستوية لغة مصرية(؟) . . والاستعمال المصري كما تلحظ غير بعيد عن أصله العربي.

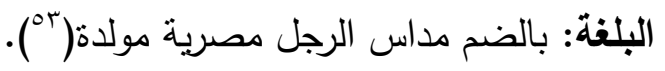

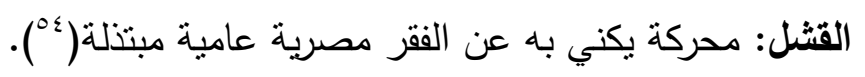
الويبة: على وزن شيبة اثتان أوأربعة وعشرون مدا، لم يذكره الجوهري ولا ابن فارس، بل بل بله توقف فيه ابن دريد، والصحيح أنها مولدة استعملها أهل الثام ومصر وإفريقية(10). غير ذلك. وعلماؤنا القدامي ومنهم الزبيدي بتسجيلهم اللهجات العامية لا يهدفون من وراء ذلك خدمة العاميات وتأصيلها بقدر ما يهدفون إلى عصمة اللسان العربي منها، وصبانته من اللحن، فالزبيدي في كثثر من الأحيان يورد الاستعمال الفصيح ويورد بعده الاستعمال العامي وينبه عليه قصدا من ذلك تحقيق كلام العرب وتتقيته من الشوائب التي علقت به، وردّ ما انحرف منه إلى أصله، ويكفي أنه قرن العامية في معجمه التاج، تاج العربية الفصحى. 
د/ مصطفى عبد الهادي عبد الستار محمد ولا شك أن هذا المنهج الذي سلكه علماؤنا القدامي في دراستهم للعامية لم يكن من من مادئ أجل العامية ولا لذاتها كما فعل المستشرقون، بل كان الهذف من ذلك خدمة الفصحى عن

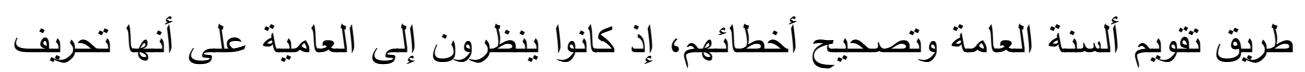
للعربية الفصحى لا على أنها لغة تختلف عن الفصحى اختلافا جوهريا، لذلك كانت مؤلفاتهم في لحن العامة فرعا من دراستهم للفصحي ومن خدمتهم لها ومحافظتهم عليها خالية من التحريف واللحن والدخيل(

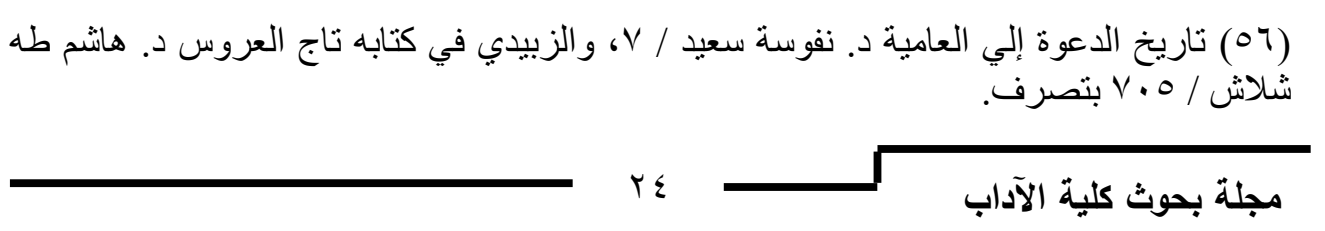


ما نسبه الزبيدي في تاج العروس إلى اللهجة المصرية

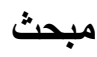

ما نسبه الزبيدي في تاج العروس إلى اللهجة المصرية

توطئة:

اللهجة المصرية وصلتها بالفصحى:

العربية الفصحى هي لغة القرآن الكريم والحديث النبوي الثريف، ولغة التراث وكنوز

التقافة العربية الأصيلة، وهي السجل الحي لحضارة عربية عريقة تضرب بجذورها بعيدا في أعماق التاريخ، وتعد الرابطة الوثقى التي تربط العرب بعضهم ببعض سياسيا وتقافيا واجتماعيا، والتي لا نزال حتي اليوم نتخذ منها لسان أدب وعلم ودين( (ov).

واللهجات العربية في وطننا العربي وما أكثرها هي تلك اللهجات المستعملة في حباتتا

اليومية الدارجة على ألسنة العامة والخاصة للتعبير عن أغراضهم، فهي لغة الثارع والبيت، لغة العامل في المصنع، والفلاح في مزرعته، والطبيب مع مريضهه، والباعة في الأسواق وغيرهم من شرائح المجتمع المختلفة، وهي وإن كانت هذه اللهجات من الفصحى في الأصل إلا أنها لم تتقيد بالضوابط والقواعد اللازمة في الفصحى، فتحررت منها، وإن كان ذللك لا لا يخرجها في الغالب عن أصلها.

وتعدد اللهجات داخل اللغة الواحدة كوجود اللهجات المعاصرة في العربية الفصحى

ظاهرة اجتماعية طبيعية، فاللغة التي تعيش على مساحة جغرافية كبيرة تتفرع إلى لهجات متعددة بحكم العوامل الجغرافية والاجتماعية والاقتصادية وغيرها، فمن المقرر في قوانين

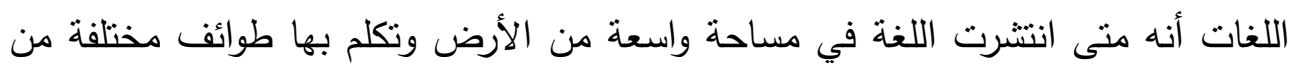

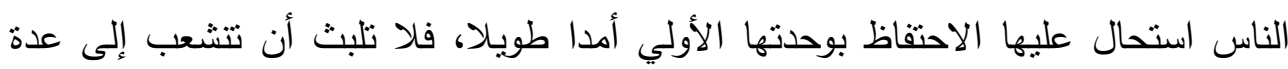

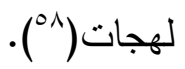

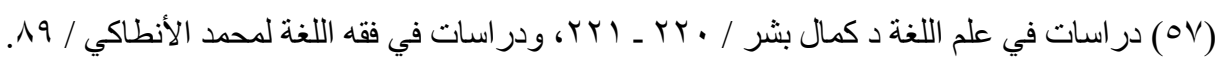

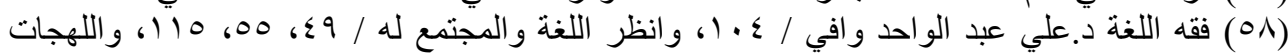

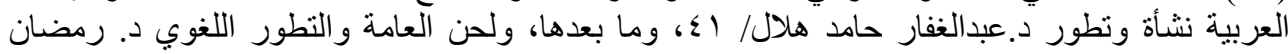

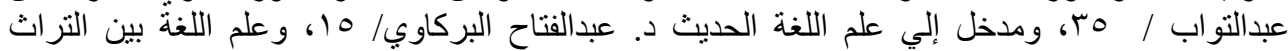

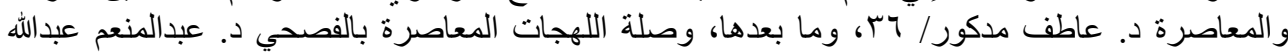

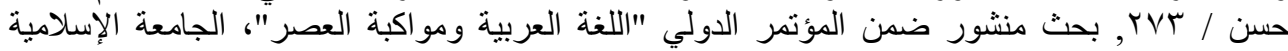

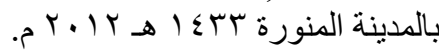




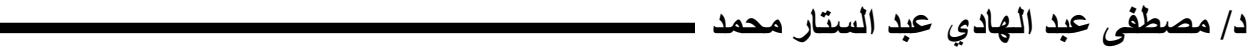

والعامية المصرية من هذه اللهجات التي تتنمي إلى العربية الفصحى، ولا تخرج في مدي

مجملها عن أصلها العربي الصحيح الضارب بجذوره في أصله السامي مع ما اعتراها من تبدل أو تطور في بعض حروفها، أو فيما اكتسبته من معان مولدة دعت إليها الحاجة

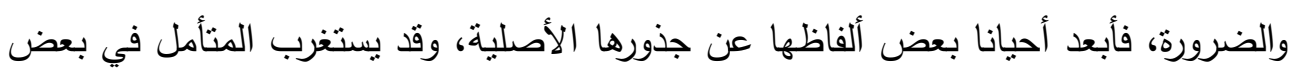
الكلمات العامية بعدها هذا القدر الكبير عن أصلها الفصيح، وقد يستبعد أن تكون هناك صلة قرابة بين الكلمنن العامية والفصيحة، وإن مثل هذا الاستغراب ليزول متى علم أن هذا التغيير في الكلمات الفصيحة لم يحدث جزافا، أو لم يحدث مرة واحدة بشكل فجائي، وإنما مثل هذه الألفاظ قد مرت بأدوار وأطوار من التغير والتطور تتاوبتها مرة بعد أخرى، وأنه

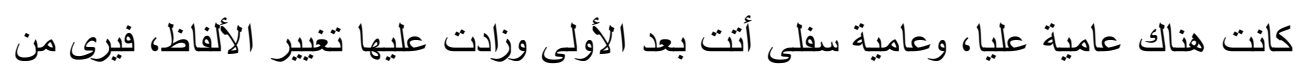
ذلك أن اللفظ العامي قد تغير مرتين في دورين غير منباعدين كثبرا من أدوار حياة

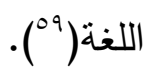

ومما يلفت النظر أن أكثر الكلمات العامية التي قد ينفر منها الذوق العام الآن، أو

يستتكرها الحس إنما كانت من أفصح الألفاظ العربية وأدقها في التعبير عما يجيش في لئه

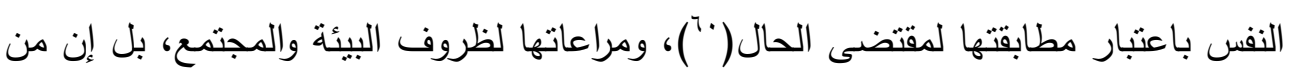
هذه الألفاظ ما يستخدمه الطلاب والدارسون في تعبيراتهم اليومية، ويقبل منهم في لغة الحديث والمناقثة أثتاء الدرس، وإذا ما كتبوها في موضوعات التعبير التحريري شجبها

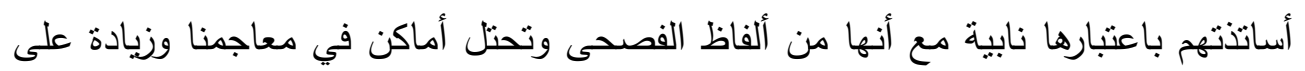

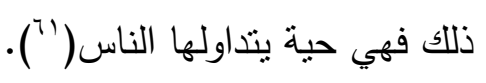
ومن ثم فإن القول ببعد اللهجة المصرية في مجملها عن أصلها العربي قول مبالغ فيه، فالفرق بينهما ضئيل للغاية، يؤكد ذلك مثن اللهجة المصرية وما يحويه من ألفاظ (09) المحكم في أصول الكلمات العامية لاحمد عيسي بك / ع ع، و وانظر من المشترك السامي العامي

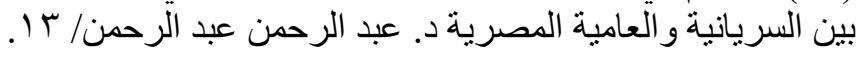

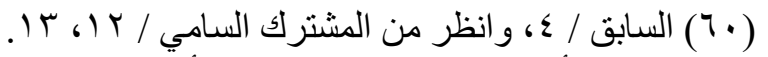

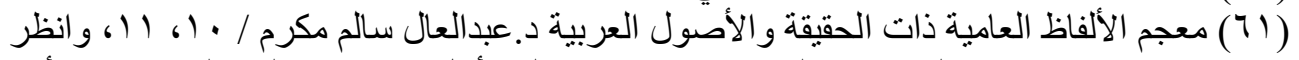

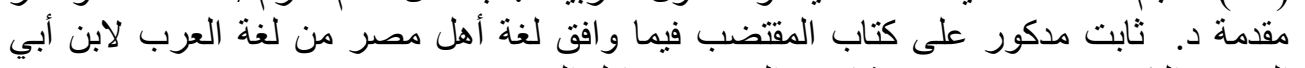

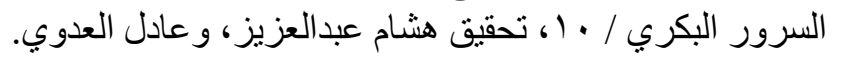


ما نسبه الزبيدي في تاج العروس إلى اللهجة المصرية

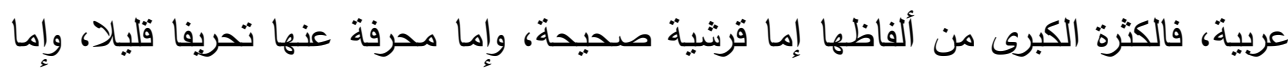

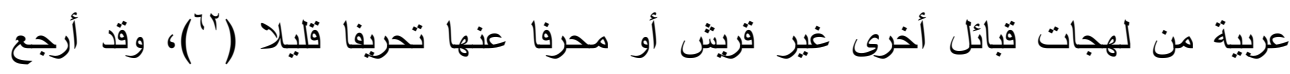

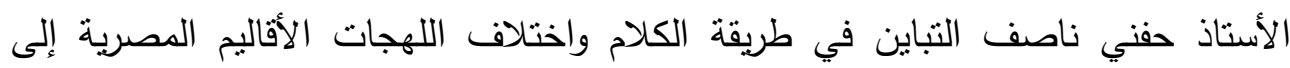

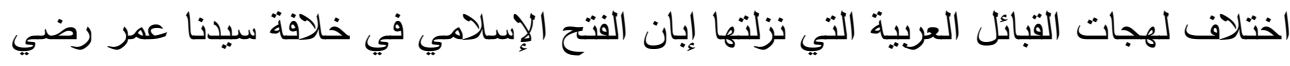

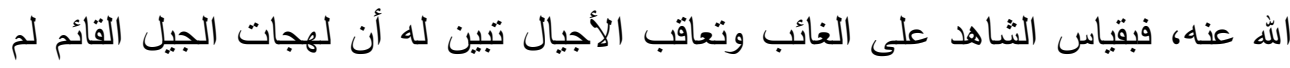

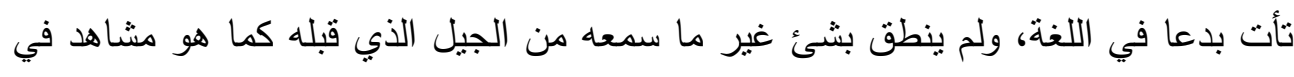

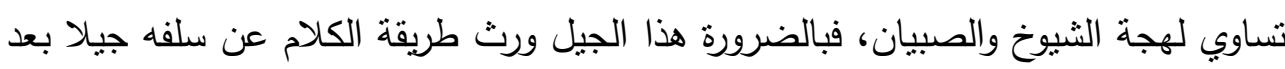
جيل حتى الجيل الذي دخلت العربية فيه أرض مصر (بآل).

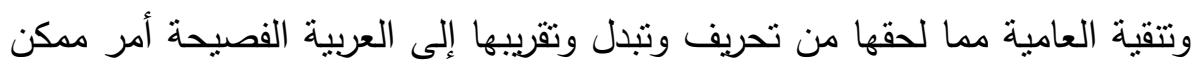

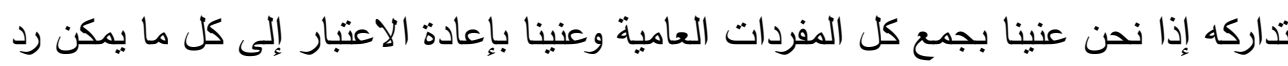

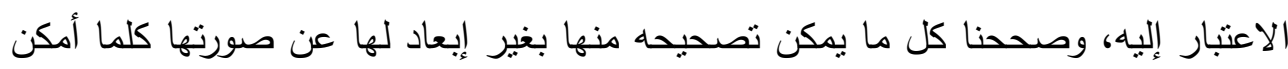

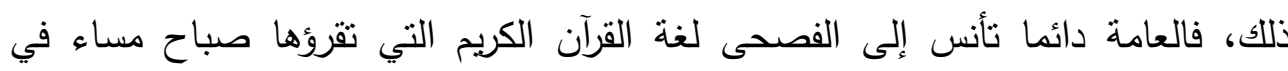

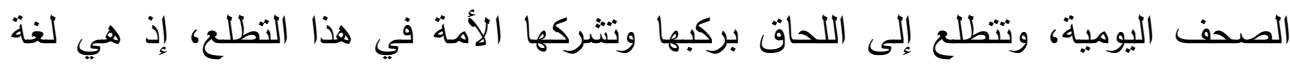

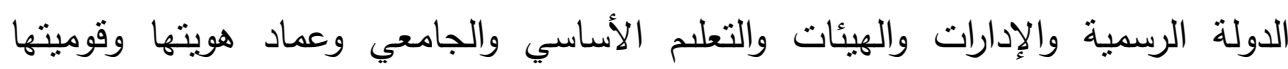

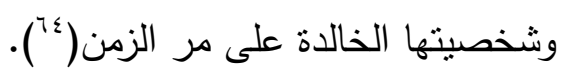
مستويات التغير اللغوي في اللهجة المصرية:

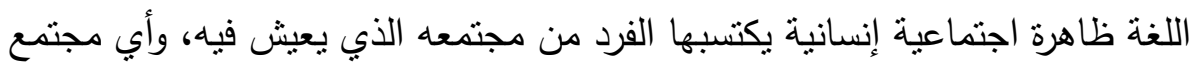

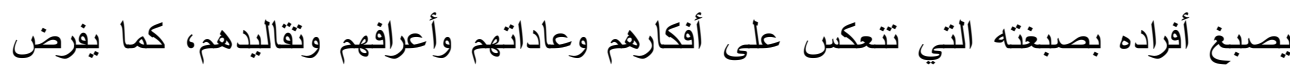

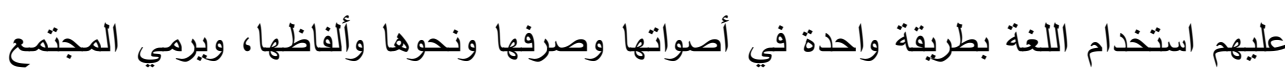

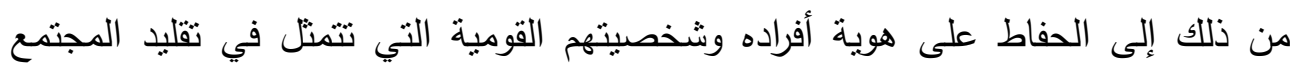

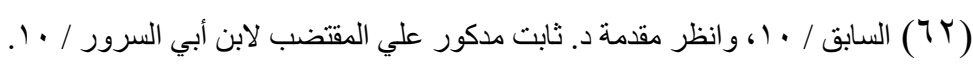

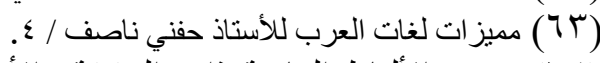

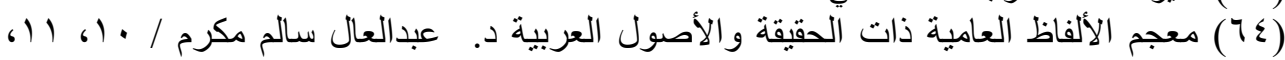

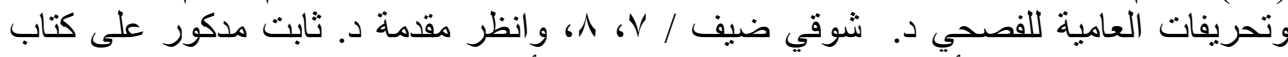

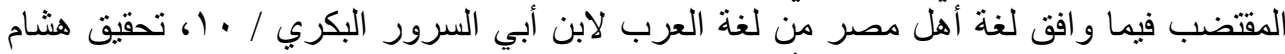
عبدالعزيز، ومعجم فصاح العربية وأثرها في التجديد اللغوي لمحمد خسارة، مجلة مجمع اللغة التها

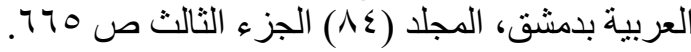




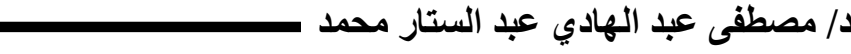
وأعرافه، كما يرمي إلى المحافظة على لغته التي هي مظهر من مظاهر شخصية المجتمع وعامل من عوامل بقائه وقيام التعاون بين أفراده. والظواهر الاجتماعية ليست ثابتة بل هي عرضة للتغير ، وإن كنا قد سلمنا بأن اللغة ظاهرة اجتماعية فهي تخضع لقانون التغير، فتتقل اللغة بظواهرها المختلفة من حالة إلى فراهي حالة أخرى، أو تحل بعض الظواهر اللغوية محل أخرى في مرحلة من مراحل تاريخ اللغة

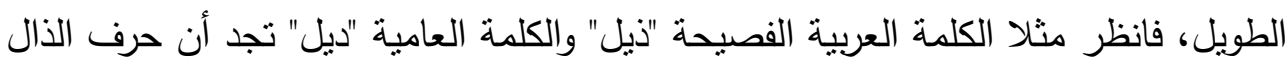
في الكلمة العربية الفصيحة يقابله حرف الدال في الكلمة العامية الثانية، والياء الساكنة في الكلمة الأولى يقابلها ياء المد في الكلمة العامية الثانية، والكلمة الأولى تمثل مرحلة من الزمن، والكلمة الثانية تمنل مرحلة أخرى، وما حدث من تغير فيهما بطلق عليه التغيير اللغوي.

وحين نريد أن نعبر في اللهجة المصرية عن الفعل المضارع المستقبل فإننا نقول: "حنكتب، حندخل، هنشرب، هنلعب" بينما نقول في الفصحى: "سنكتب أو سوف نكتب،

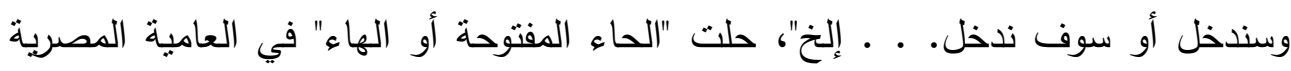
محل "السين" أو "سوف" للتعبير عن الاستقبال في الفعل المضارع، وهذا ما يطلق عليه أيضا التغير اللغوي، فالتغير الذي يلحق اللغة له أكثر من مستوى، فقد يصيب التغير

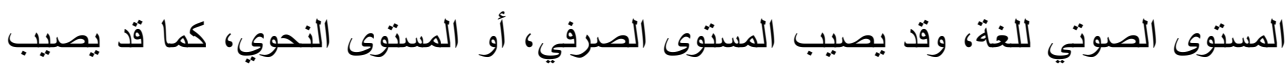

دلالة الألفاظ.

\section{التغير الصوتي: - n}

النظام الصوتي للهجة المصرية عند مقارنته بالنظام الصوتي في اللغة العربية الفصحى تجد أن تغيرا كبيرا قد طرأ عليه، فقد انقرض حرف "الثاء" من اللهجة المصرية

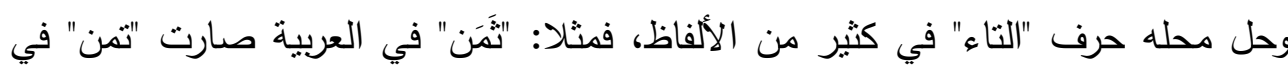

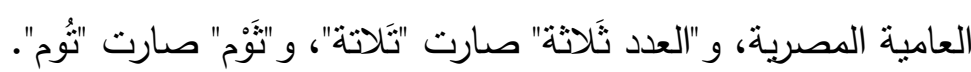

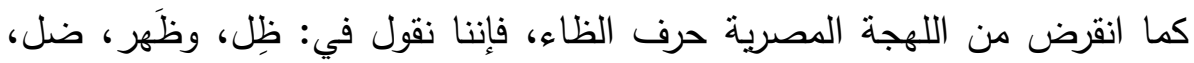
وضهر ، وحرف "الذال" حل محله حرف "الدال"،أو الزاي، فلفظ "ذَيْل" في الفصحى صارت 
ما نسبه الزبيدي في تاج العروس إلى اللهجة المصرية

"دِيل" في العامية المصرية، و "ذِراع" في الفصحى صارت "دِراع"، ولفظ "ذنب" في الفصحى فاج صارت على السنة المصريين "زنب".

وحرف "القاف" تغير على ألسنة المصريين من أهل القاهرة والمدن المصرية وحل محلها حرف "الهمزة"، أو حرف الجيم، فالفعل "قال" في الفصحى صارت "آل" أو "جال" في العامية المصرية، ولفظ "قمر" في الفصحى صارت "أَمَر" أو "جَمَر" في العامية المصرية. التغير الصرفي والنحوي: يتمثل الخلاف بين العربية الفصحى واللهجة المصرية في المستوى الصرفي والنحوي في بعض الصور، فالموصول في العامية المصرية له اسم واحد "اللّي" ولا يتطابق مع موصوفه لا في حالة الإفراد والتثنية والجمع، ولا في حالة التذكير والتأنيث بل بلزم حالة واحدة في كل، أما الموصول في العربية فله أسماء كثيرة، ويتطابق مع موصوفه إفرادا وتثنية وجمعا، وتذكيرا وتأنيثا، ومن الأمثلة على ذلك: أننا نقول في الفصحى: الولد الذي لعب، الفيكاء وفي العامية: الولد اللّي لعب، ونقول: البنت التي لعبت، البنت اللي لعبت، الأولاد اللذين لعبوا، الولاد اللي لعبوا. كما تستخدم اللغة العربية الفصحى صيغا خاصة للفعل المبني للمجهول، أما في اللهجة

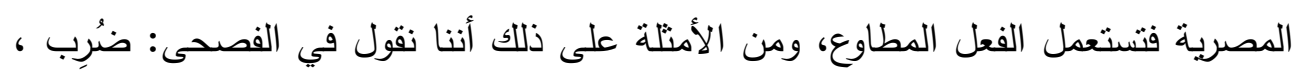
يُضرب، وفي العامية: انضرب اضَّرب ينضرب، إلى غيرذلك مما لحق بنية اللهجة

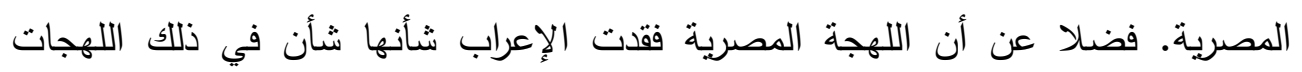

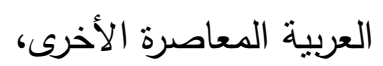
التغير الدلالي: - n

التخير والانتقال من حالة إلى حالة أخرى أمر يحتمه تغير المجتمعات في عاداتهم وتقاليدهم وأحوالهم المعيشية وأفكارهم وفلسفاتهم، وداخل المجتمعات تظهر أثنياء ومخترعات

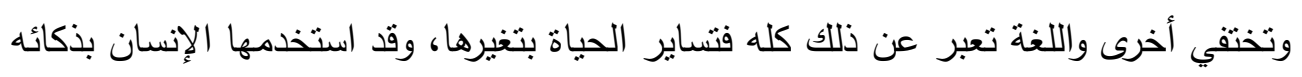
اللغوي، فأضاف إلى دلالات الألفاظ المعروفة عنده، والمسجلة في معاجم اللغة دلالات جديدة، وبهذه الطريقة نجح في التعبير عن احتياجاته وعن ثقافة عصره، ومن الأمثلة على دلى دالى ذللك في الفصحى لفظ القطار : يطلق على عدد من الإبل تسير خاف بعضها، وفي اللهجة 


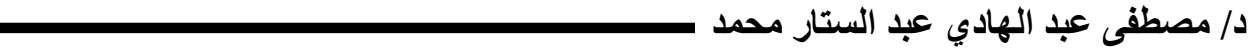
المصرية بطلق مجموعة من المركبات تجرها قاطرة على سكة من حديد، ولفظ والسيارة بعني مليد في الفصحى القافلة، وفي العامية المصرية لفظ مولد بطلق على عربة إليه تسير بالبنزين ونحوه تسخدم في الركوب والانتقال من مكان إلى مكان(10) إلى غير ذلك.

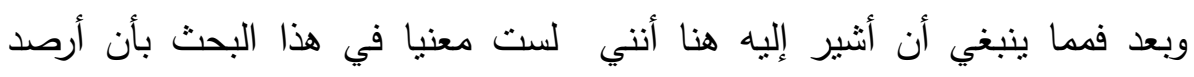

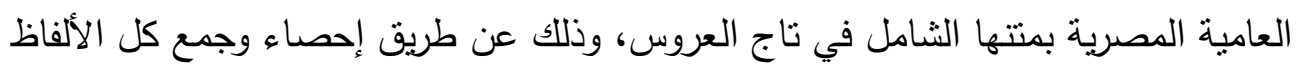
التي نص عليها الزبيدي في تاجه بأنها عامية أو محدثة مولدة، وإنما الهدف من هذا البحث

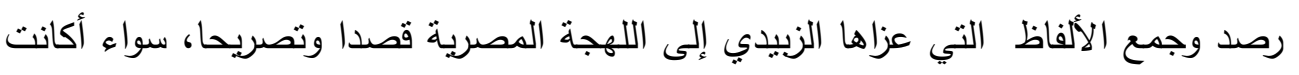
النسبة إلى مصر أو إلى بعض أقاليمها . وتؤكد هذه الدراسة على أن العامية المصرية التي نسبها الزبيدي إلى أهل مصرترجع

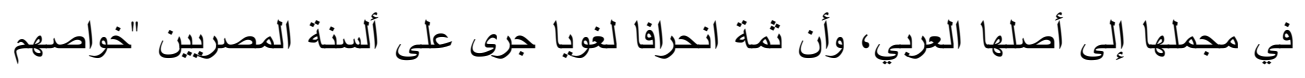
وعوامهم" أبعدها قليلا أو كثيرا عن أصلها العربي، وإن بدا بالتأمل اشتراك الألفاظ العامية بمعانيها المستحدثة مع الفصحى في جذورها العربية الأصلية، بل إن هناك ألفاظا كثيرة في بأن عاميتتا المصرية لا زلنا إلى الآن نستخدمها بمنطوقها ومعناها العربي الفصيح. ولا يغيب عنا في هذه الدراسة أن من الألفاظ العامية ألفاظا تمت بصلة وثثية إلى نى جذور غير عربية، قد تكون فارسية أو تركية أو آرامية أو مصرية قديمة أوتتتمي إلى لغة من لغنافي اللغات اللاتينية تبعا لتأثز اللهجة المصرية واحتكاكها بهذه اللغات على مداها الطويل والممتذ إلى ما قبل الإسلام. والأمر الذي ينبغي أن تقف عليه هذه الدراسة وتؤكده يتمنل في رصد جميع هذه

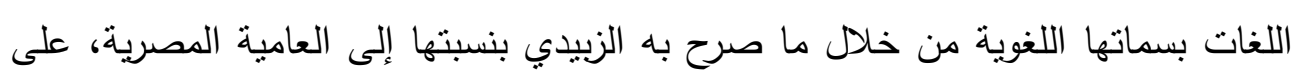
أن اللهجة المصرية تشتمل على هذه اللغات تأثرا، وإن كان هذا لا يخرجها أعني اللهجة

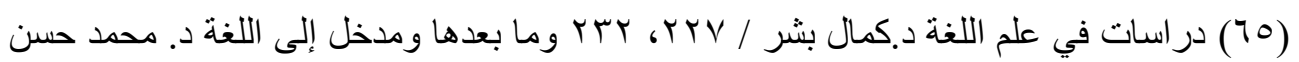

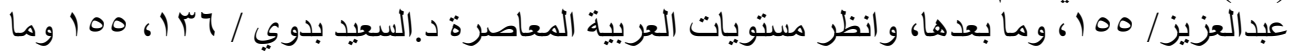

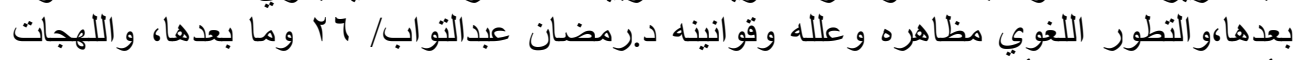

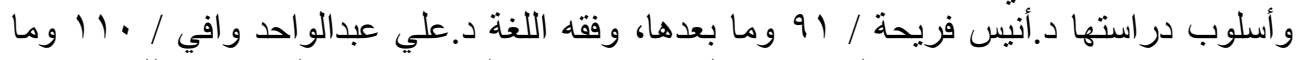

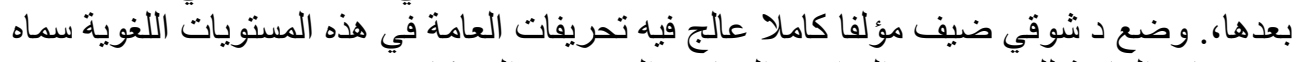

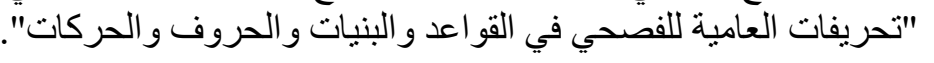

r. مجلة بحوث كلية الآداب 


\section{ما نسبه الزبيدي في تاج العروس إلى اللهجة المصرية}

المصرية عن أصولها العربية الفصيحة بلهجاتها العربية القديمة، ومن ثم يتحقق لنا من هذه الته الدراسة أمران على درجة كبيرة من الأهمية:

الأول: المقارنة بين مستوبين من مستويات اللغة، المستوى الفصيح، والمستوى العامي، وذلك للكثف عن العلاقة بينهما، والأسباب التي أدت إلى تطور المستوى الأول الفصيح وتولد العامي منه.

الثاني: بيان أن جل ما يستخدمه العامي في لغته متصل باللغة الفصيحة من خلال

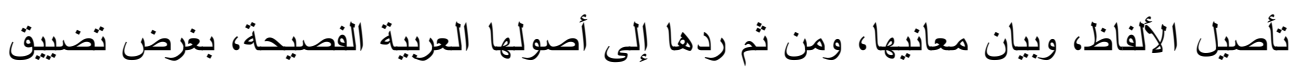
الهوة بين العامية والفصحى، والوصول إلى الهدف الأسمى المتمنل في إنهاء هذه الازداواجية، عن طريق تقصيح العامية وإزالة ما علق به من انحراف وتغير • وإليك هذه الألفاظ التي نص عليها الزبيدي في تاجها:

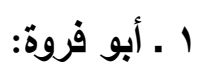

الفرو: جلد بعض الحيوان والثعالب يدبغ ويتخذ منه ملابس للدفء وللزينة(7)، وأبو فروة من الألفاظ التي استخدمها المصريون، فأطلقوها على نوع من الثجر لمشابهته فرو الحيوان. يقول الزبيدي:" وأبو فروة: البلوط، مصرية، سمي بذللك لأن في داخل قشره كهيئة

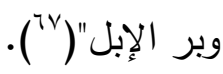

وفي المعجم الوسيط ما يدل على صحة ما نصَّ عليه الزبيدي، ففيه:" وأبو فروة: القَسْطل أو الشاه بلوط مصرية"(^)" وشاه بلوط أي بلوط الملك،، وهو شجر الكستتة

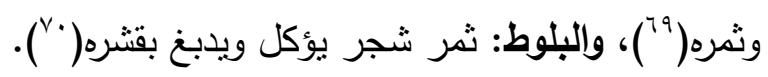

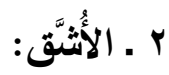

قال الزبيدي "الاشَّق كسُكَّر: أهمله الجوهري، دواء كالصمغ، دخيل في العربية. . .

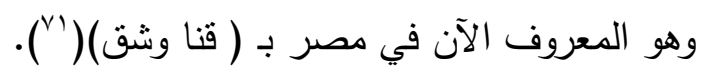




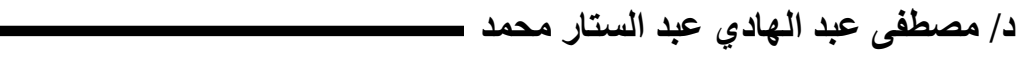

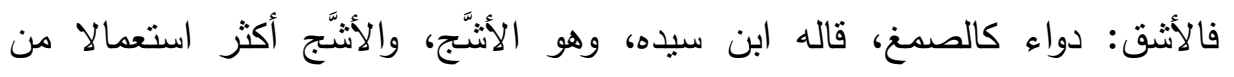

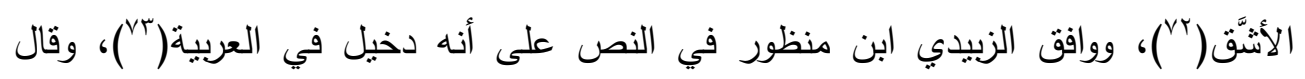

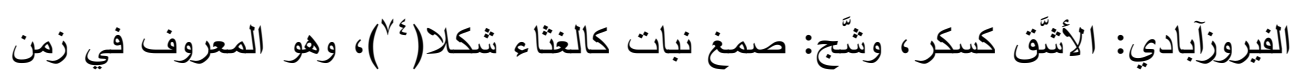
الزبيدي في مصر بـ ( قنا وشق)، وفي المعجم الوسيط: هو : صمغ طبي يستخرج من أنواع

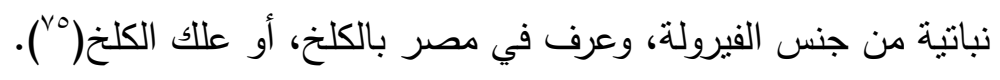

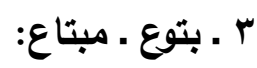

كثف الزبيدي عن اللهجة المصرية في هذين اللفظين عند عرضه لمادة ( ب ي ع ) ودلَّل على رأيه في أصل مادة هذه اللهجة بمشتقاتها. قال:" ( وابتاعه اشتراه)، يقال هذا الثيء مبتاعي أي: اشتريته بمالي، وقد استعمله المصريون في كلامهم كثيراً فيحذفون الميم،

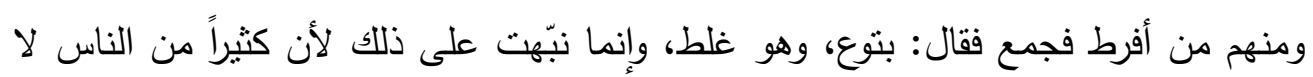

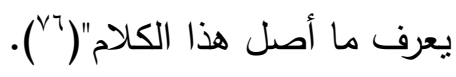
وهو أيضا مما تردد صداه قديماً وإن لم يفصحواً عمَّا حدث فيه من تطور عند بعض من لهج به كالمصريين، فمبتاع على وزن مفتعل من ( ابتاع ) ليس بين الفاعل والمفعول من هذا النحو فرق تقول: ابتاع الرجل الثيء، فالرجل مبتاع والثيء مبتاع أيضاً، وذلك لما حدث فيه من من هدول

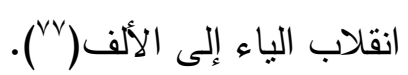

هذا هو الوجه الذي عرفته الفصحى بيد أن العامية المصرية عرفت وجهاً آخر في الألي

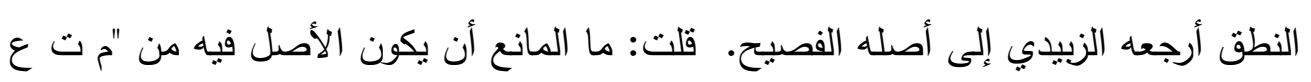

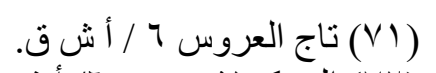

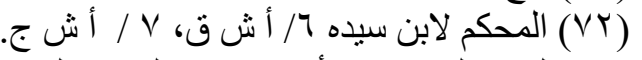

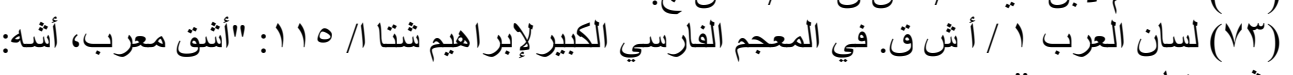
و وشق، نبات صمغي".

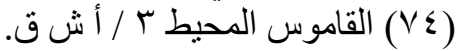

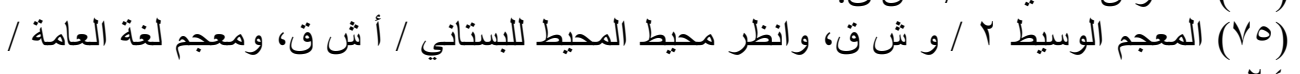

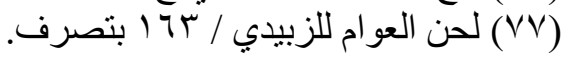

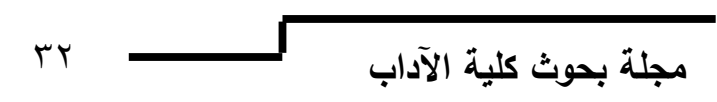


ما نسبه الزبيدي في تاج العروس إلى اللهجة المصرية

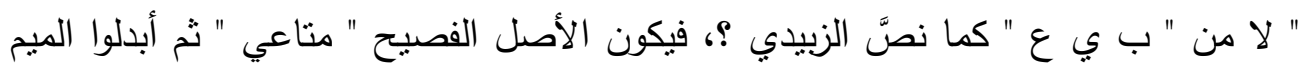
باء، فصارت " بتاعي " وهو إبدال معروف عند العرب قديماً تسوّغه العلاقة الصوتية من العن اشتراك في المخرج، وفي بعض الصفات((v)،، فالعرب تقول: بكة ومكة، ومكانك وبكانك،

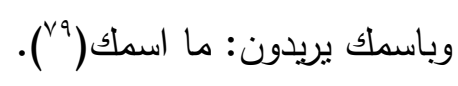

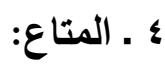

المتاع: كل ما ينتفع به من عروض الدنيا قليلها وكثيرها(^)، كالطعام والبزَّ وأثاث

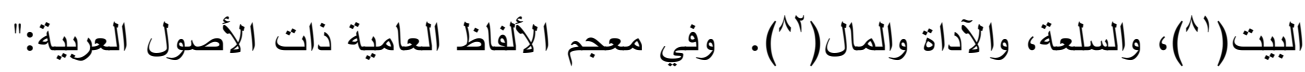

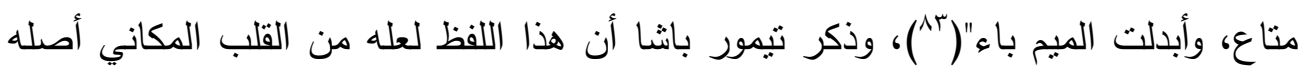
تباع أو من قلب الميم باء وأصله متاع، ولعل هذا الرأي هو الذي مال إليه الزبيدي في نهاية المطاف، فقد نصَّ في التكملة على أن البتع بالفتح: القوة والصلابة وهو باتع أتع أي شديد قوي

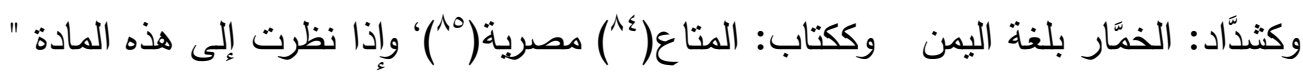

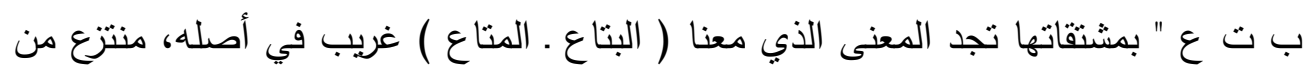

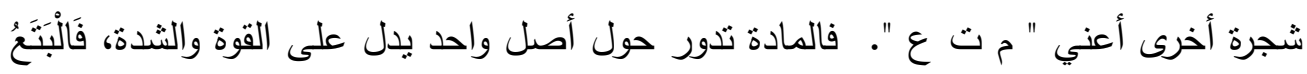

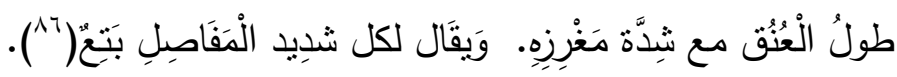

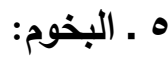

قال الزبيدي:" ومما يستدرك عليه البخوم كصبور كلمة قبطية اسم لقرية بمصر

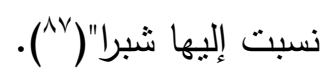

(VA) (Vq) .119/1 -

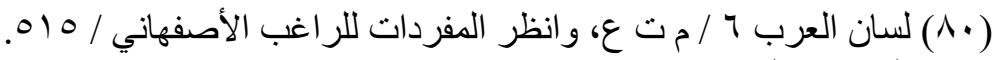

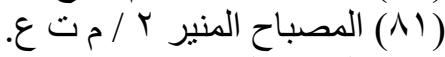

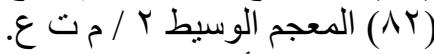

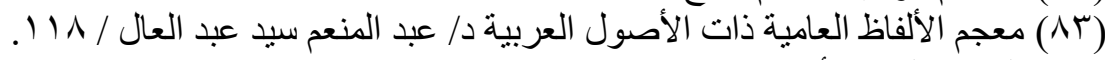

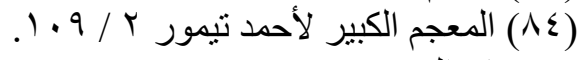
)

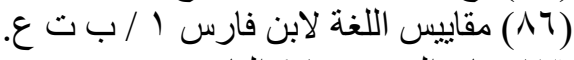

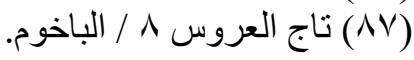


د/ مصطفى عبد الهادي عبد الستار محمد

وحتى الآن يقال: شبرا بخوم، والزبيدي هنا ضبط اللفظ بالفتح فهو كصبور ، وفي

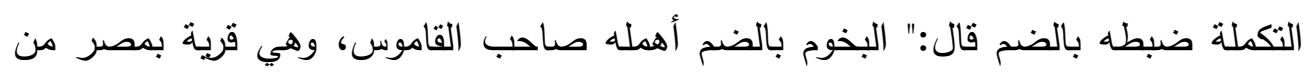

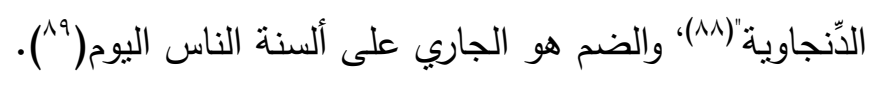

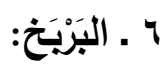

البربخ: نقوله في دراجتنا: لأنبوب خزفي نستخدمه كمجرى للماء ونحوه تحت الأرض

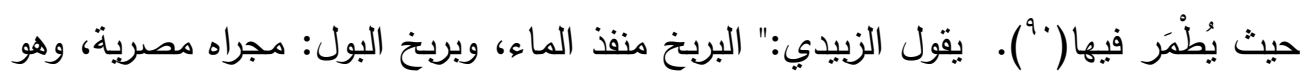

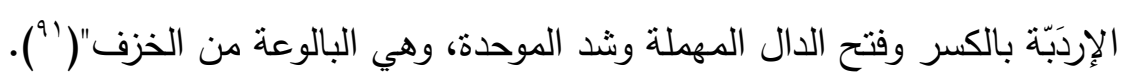
وفي المنصوص عليه عند بعض اللغويين: البربخ منفذ الماء ومجراه، وهو الإردَبَّة والبالوعة من الخزف(rو") من غير نص على أنها من العامية المصرية، وقد تأثز المعجم

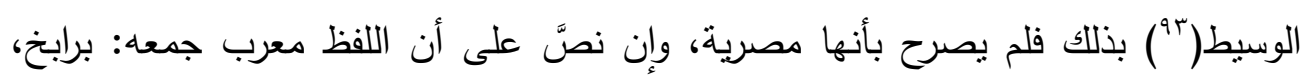

$$
\text { ومرادفه العربي الإردبة. }
$$

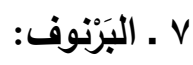

البَرْنوف: نبات من الفصيلة المركبة مُعَمِّر يكثر في مصر على شواطئ الترع

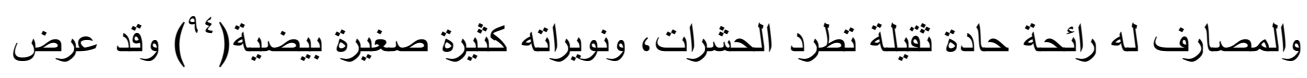

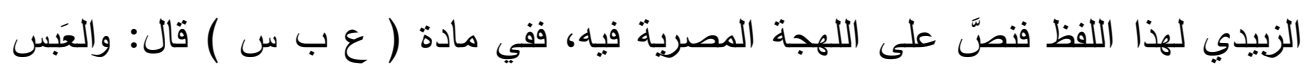
بالفتح نبات ذكره ابن دريد، وقال أبو حاتم فارسيته شاب بك، وقال مرة: أوالسيّيسنبَر، ويقال هو البرنوف بالمصرية كما سيأتي في محله(

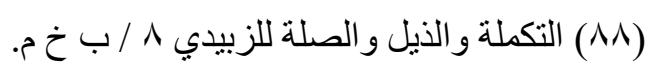

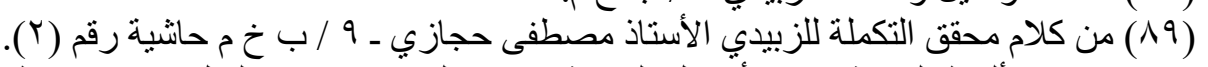

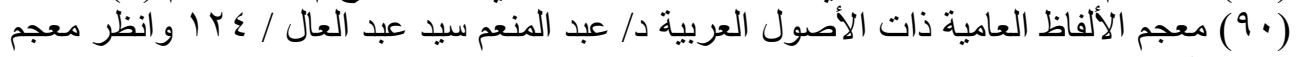

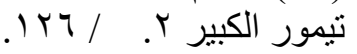
(9) (9) تاج العروس r / / البربخ.

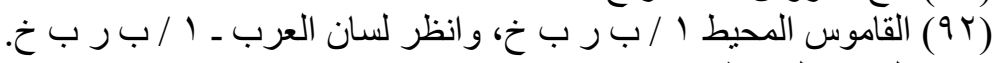

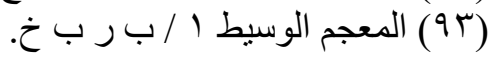

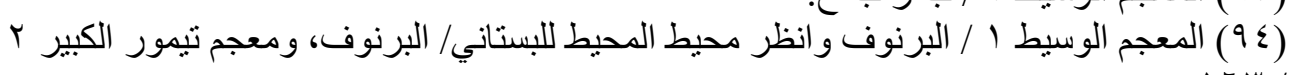
. (90) تاج العروس ع / ع ب س.

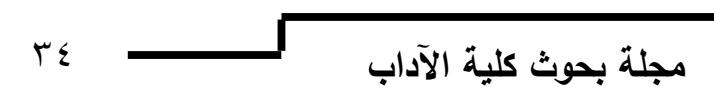




\section{ما نسبه الزبيدي في تاج العروس إلى اللهجة المصرية}

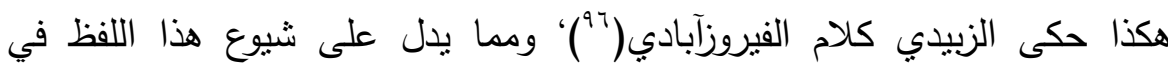
عصر صاحب القاموس، وفي محل اللفظ الذي معنا ( البرنوف ) من المعجم صرح الزبيدي بأن البرنوف كصعفوك أهمله الجماعة نبات معروف كثير بمصر ينبت على حروف الترع والجسور وفي الأرض السهلة لا فرق بينه وبين الطيون إلا نعومة أوراقه أو عدم الدبق فيه، بئه

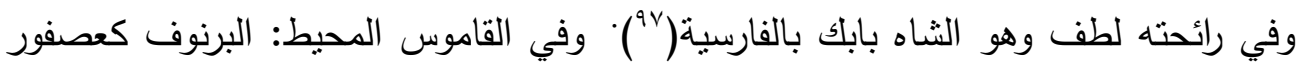

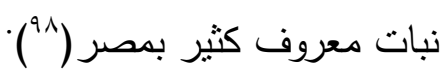

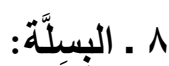

قال الزبيدي:" البِيلَّى بكسرتين مشددة اللام حب كالترمس، أو أقل منه لغة

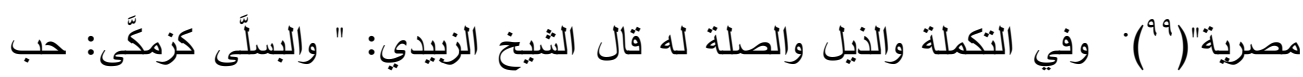

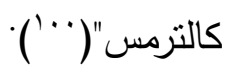

وعليه : فالبِسِلَّى وكذا البسلَّة مما لهج به المصريون، وقد عرفها المعجم الوسيط بأنها: بقل زراعي حولي من القرنيات الفراشية، ضروبه كثيرة وتطبخ بذوره معرب( '.' دخيل

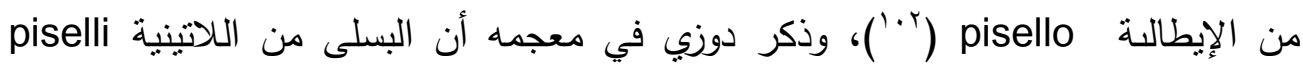

البشتيك نوع من الجوالق في لغة العامة من المصريين، صرح بذلك الزبيدي فيما استدركه على صاحب القاموس. قال: البشتيك: خُرج الراعي الذي يعلقه على التيس، وهو

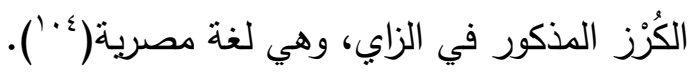

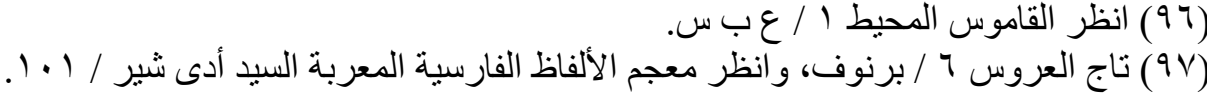

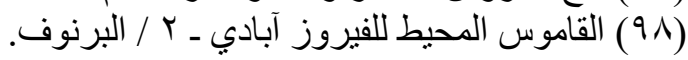

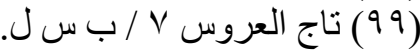

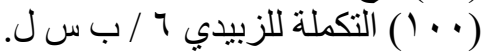

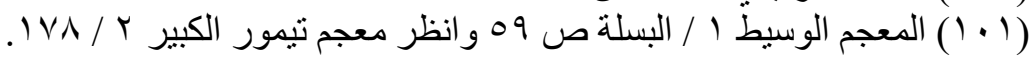

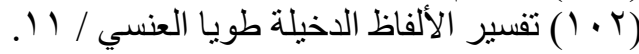

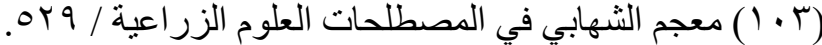

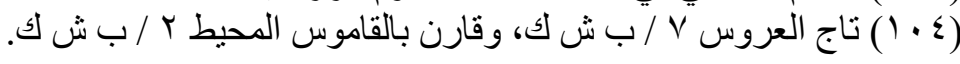




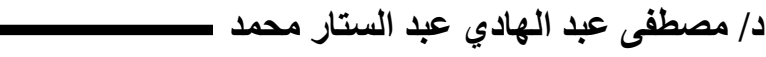
ويالعودة إلى مادة ( ك ر ز ) ): نجد فيها ما نصده:" الكُرزز : ضرب من الجُوالق، وقيل: هو الجُوالق الصغير، وقيل: هو الخُرْج، وقيل: الخُرج الكبير يحمل فيه الراعي زاده

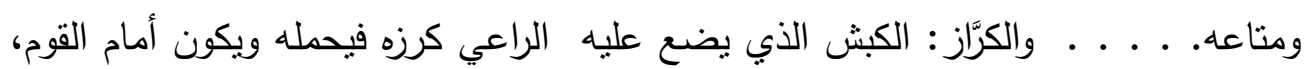
ولا يكون إلا أجم، لأن الأقرن يشتغل بالنطاح( هذا وليس في المعاجم القديمة ما نصَّ عليه الزبيدي سابقاً، غاية ما قيل في هذه الهان المادة ( ب ش ك ): البشك: سوء العمل، والبشك: الخياطة الرديئة، ابن الأعرابي يقال للخيّاط إذا أساء خياطة الثوب: بشكه وشمرجه، وبشكت الثوب إذا خطته خياطة متباعدة(1.7) فلعل البشتيك كان في اللغة المصرية من هذا المعنى الأخير كان يخاط خياطة

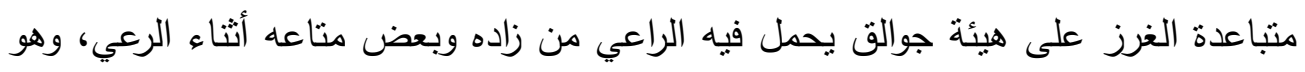

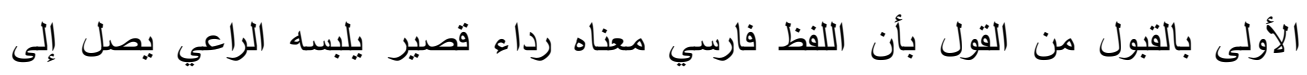

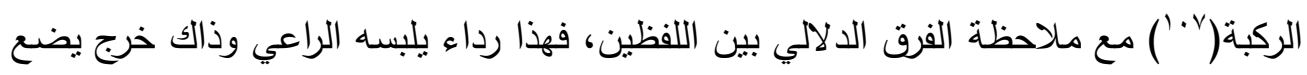
فيه الراعي متاعه، فربما اللفظ مع اختلاف اللغتين في المعنى يدل على ذلك أن " البشت "

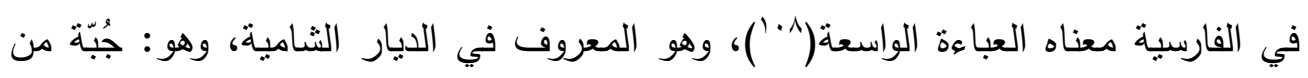
وبر أو صوف قصيرة الأكمام غليظة النسج لا يتجاوز طولها الركبة يلبسها الرُّعاة ونحوهم على الغالب(9.1)، وفي الريف المصري يطلق على المعطف الذي يرتديه الفلاح البشت('")، وفي معجم تيمور يطلق الآن البشتيك عند الحذائين على وجه النعل، أي لئي

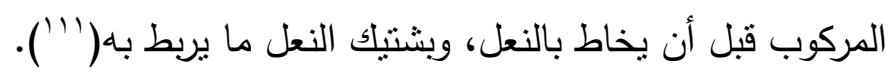

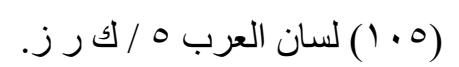

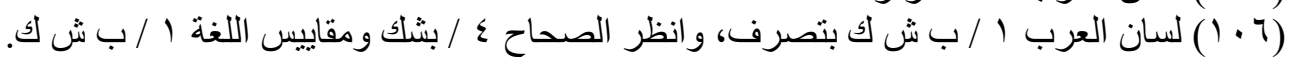
وشرج ثوبه: خاطه خياطة متباعدة الكتب وباعد بين الغرز وأساء الخياطة لسان العرب ع / ش م م

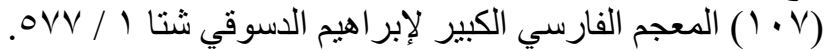

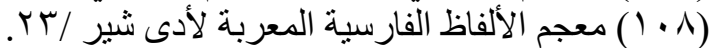

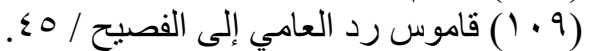

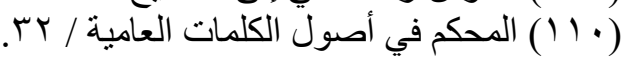

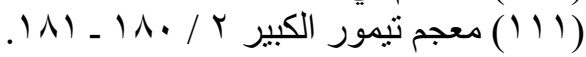


ما نسبه الزبيدي في تاج العروس إلى اللهجة المصرية

•

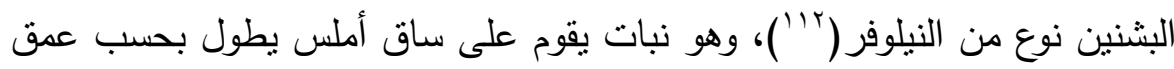

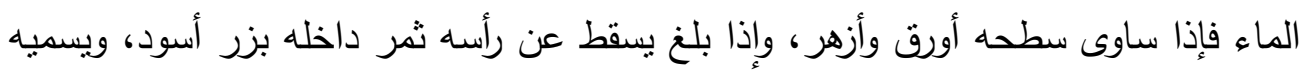

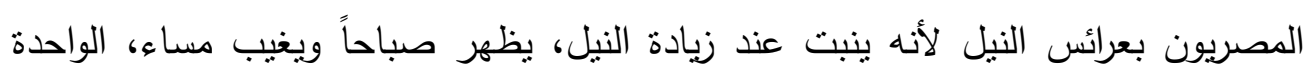

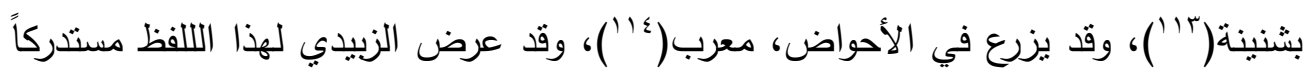

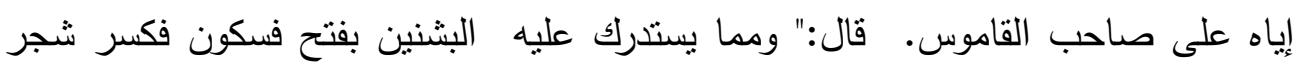

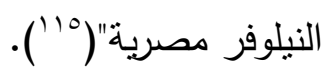

وفي النكملة له أيضاً البشنين بالفتح وكسر النون: النيلوفر مصرية"(" ")، ولم

يقتصر الزبيدي على ذلك، بل عرض لهذا اللفظ عند ذكر مرادفه " النيلوفر ، فقال:" النيلوفر:

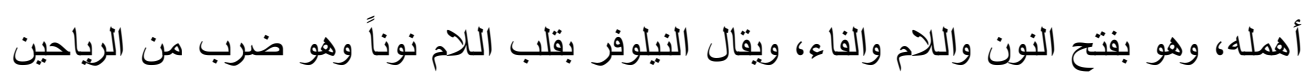

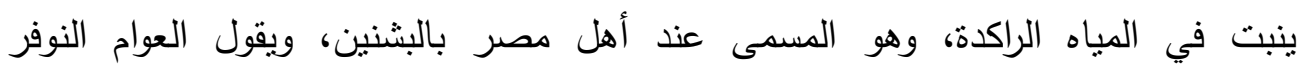

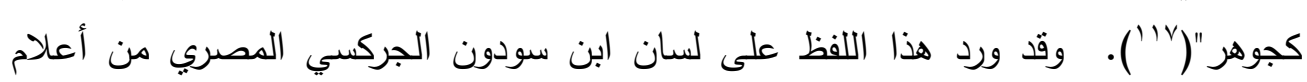

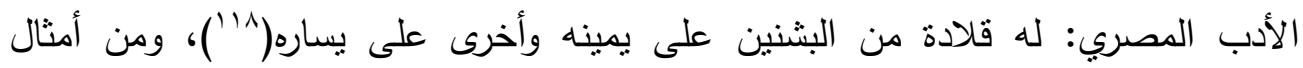

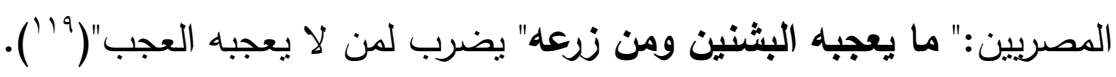

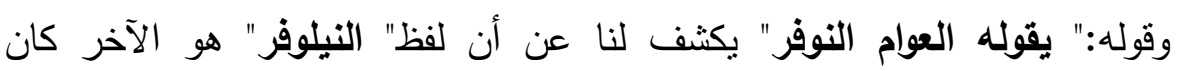

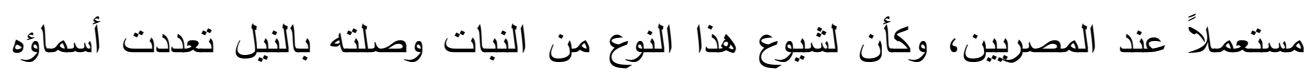

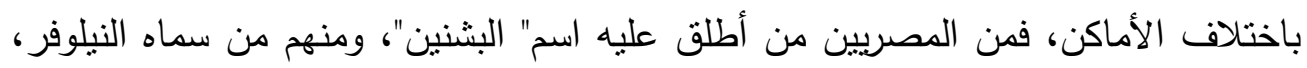

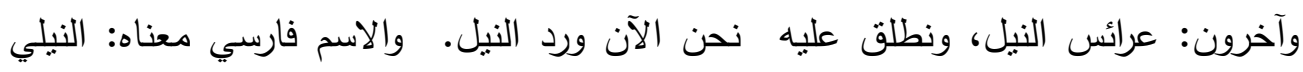

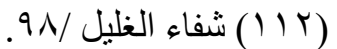

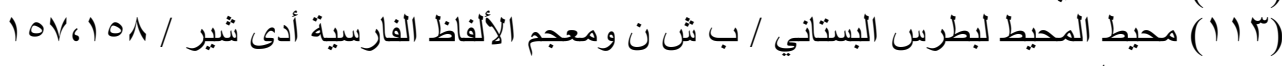
بتصرف فيهما.

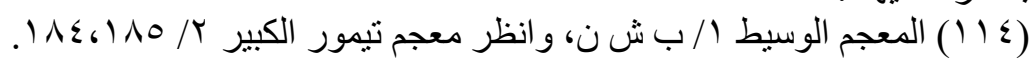

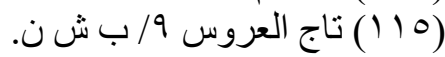

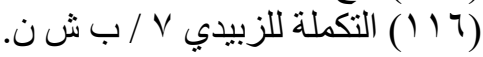
(I IV)

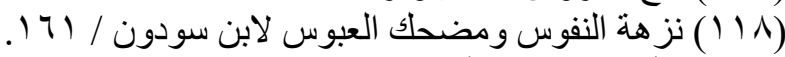

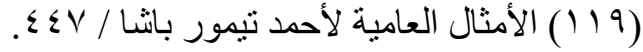




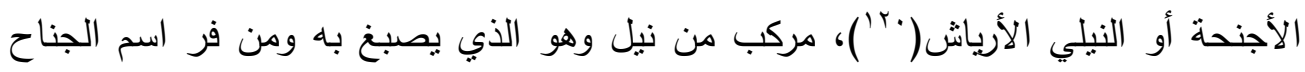

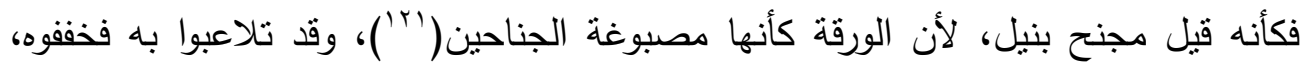

لفظ البطاقة من الألفاظ الثائعة في اللهجة المصرية قديماً وحديثاً، وقد عرض الزبيدي لما قيل فيها فلخص آراء اللغوبين بما لا يزاد عليه. قال:" البطاقة ككتابة الحدقة هكذا

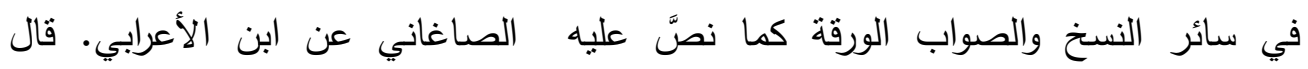
الجوهري:" هي الرقعة الصغيرة المنوطة بالثوب التي فيها رقم ثمنه، إن كان متاعاً، ووزنه

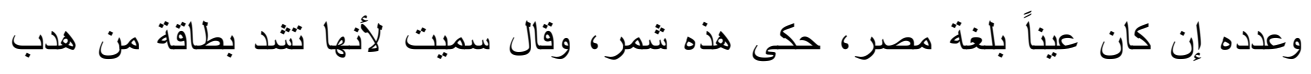

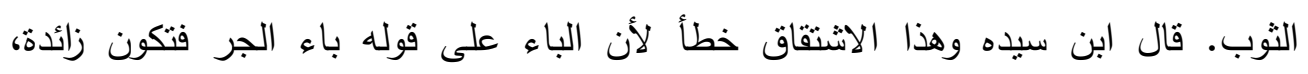
والصحيح فيه قول ابن الأعرابي أنها هي الورقة، وقال غيره ويروى بالنون لأنها تتطق بما هو الناء مرقوم فيها، وهو غريب، وهي كلمة مبتذلة بمصر وما والاها، يدعون الرقعة التي تكون في الثوب، وفيها رقم ثمنه بطاقة هكذا خصص في التهذيب، وعم المحكم به، ولم يخص به وهن

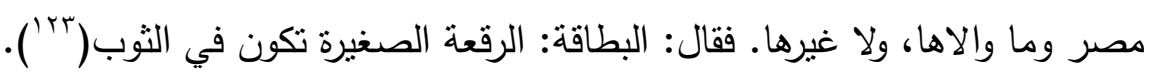

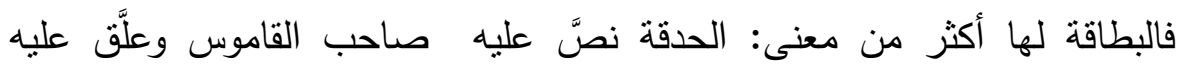
الثارح بأنه في جميع نسخ القاموس هكذا، ورفضه،، والورقة وهذا عن ابن الأعرابي، والبطاقة

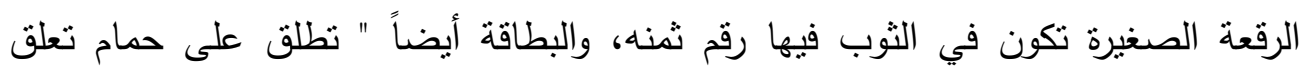

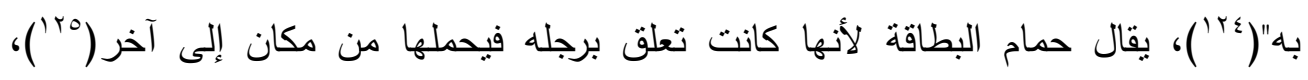
والبطاقة الآن على حد تعريف المعجم الوسيط: الرقعة الصغيرة من الورق وغيره يكتب عليها

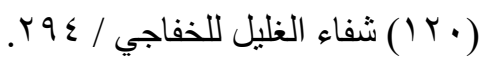

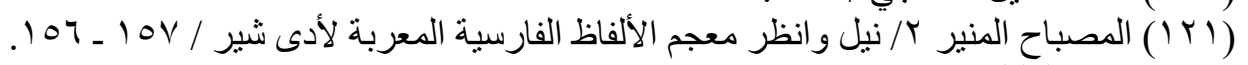

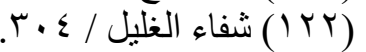

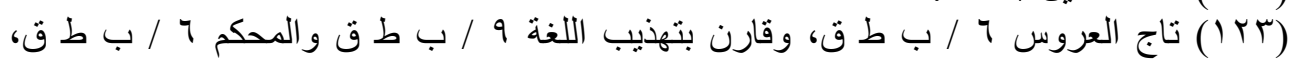

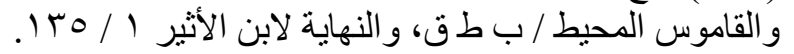

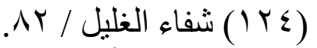

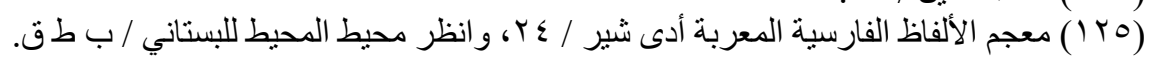




\section{ما نسبه الزبيدي في تاج العروس إلى اللهجة المصرية}

اسم الشخص وعنوانه أو بيان ما تعلق عليه، والبطاقة الشخصية: صحيفة يسجل فيها بيان النيان يثبت شخصية صاحبها باعتراف رسمي، والبطاقة العائلية: صحيفة يسجل فيها أسماء العائلة

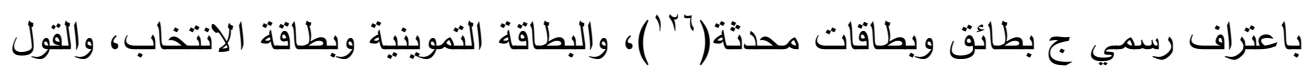
بأنها محدثة يسبقه القول بأنها مولدة، ذكره صاحب شفراء الغليل، وعلَّق عليه بقوله:" قلت

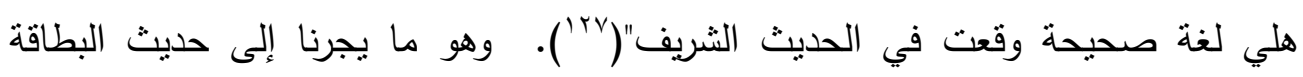

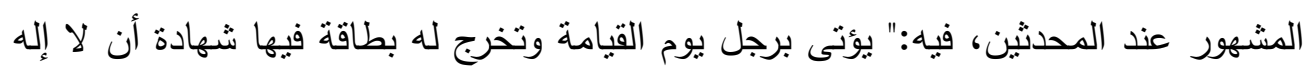

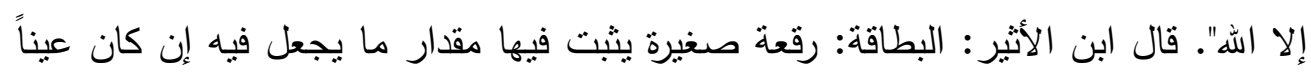

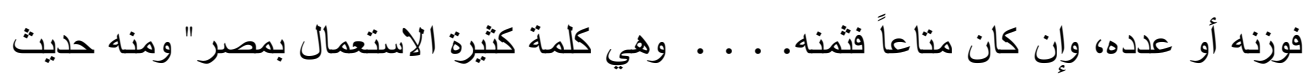

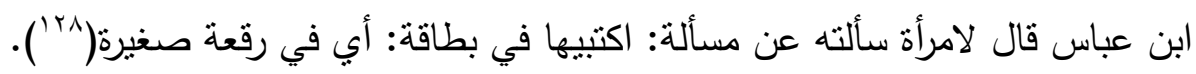

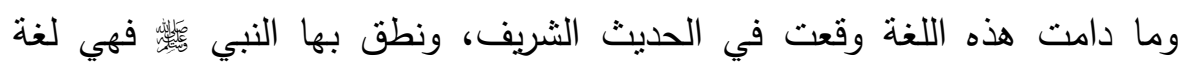
صحيحة فصيحة، فكيف يقال عنها أنها مولدة أو مبتذلة بمصر وما والها؟ لكونها كذلك كما ولها

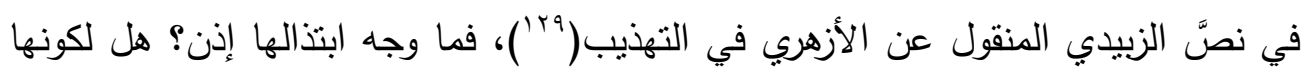
دارت على ألسنة العامة؟ حتى ولو قلنا إنها مولدة فذاك مخصوص للمعي للعاني الجديدة الحادثة لا تلك التي كانت في عصور الاحتجاج، وهي كلها كما ترى معان متصلة بعضها ببعض، الأخير يشبه الأول في المعنى وإن خالفه في الاستعمال.

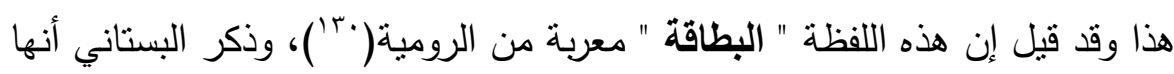

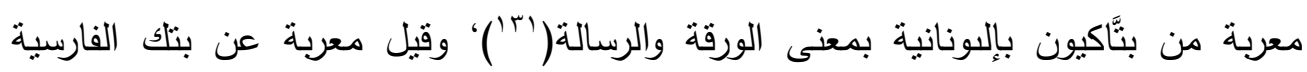

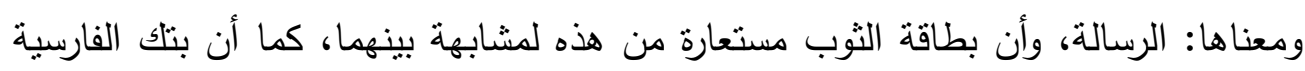

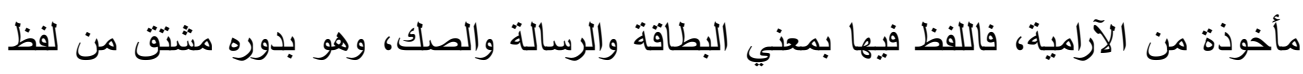

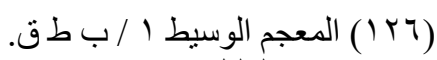
Ar / شفاء الغليل (I TV)

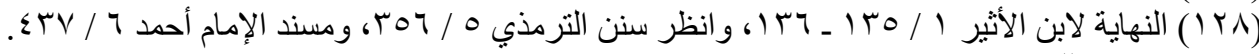

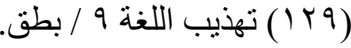

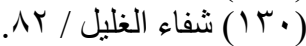

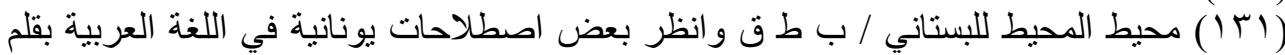

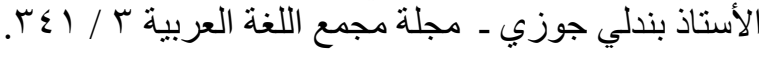


د/ مصطقى عبد الهادي عبد الستار محمد

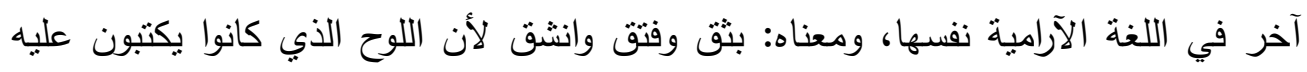
كان يشق من الخشب وغيره(r با')، أي أن اللفظ سامي الأصل عربي الأرومة.

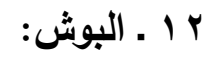

قال الزبيدي:" البوش الجماعة المختلطة من الناس، أو جماعة القوم لا يكونون إلا

من قبائل شتى ... والبوش: طعام بمصر من حنطة وعدس، يجمع ويغسل في زنبيل،

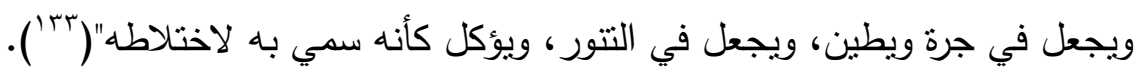

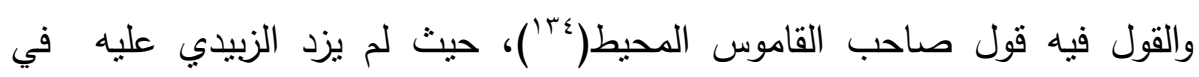

وصف هذا اللون من الطعام إلا ما ذكره في ربطه اللفظ العامي ومدلوله بأصله في العربية

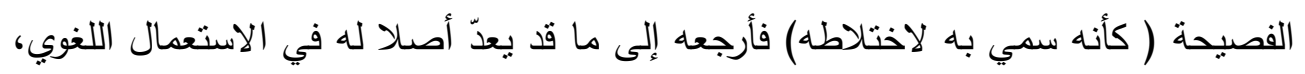
إذ البوش في اللغة نطلق على الجماعة من الناس المختلطين، يقال: بوش بائش، والأوباش:

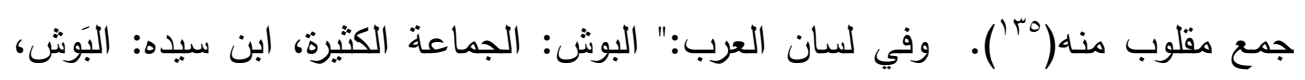
والبُشُ: جماعة القوم لا يكونون إلا من قبائل شتى، وقيل: هما الجماعة والعبال. . . . . ل

وهذا الاستعمال العامي نص عليه أيضا غير واحد(بVآ)، ونحن نقول في العامية المصرية: الثئ الفلاني باش في الميَّه، باش يبوش بوشاً: إذا اختلط، استعاروه لاختلاط

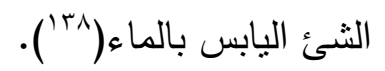

يقول الدكتور شوقي ضيف:". . . . وكأن المعاصرين استخدموها بمعني خلط الخبز بالماء على طريق الاستعارة، من الاختلاط بين الناس إلى الاختلاط بين الخبز والماء، أو

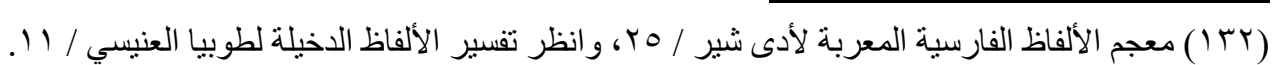

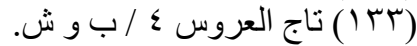

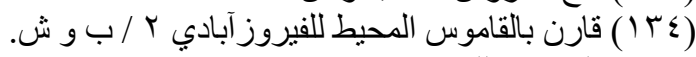

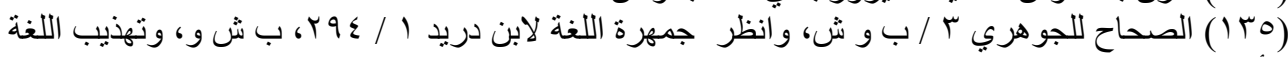

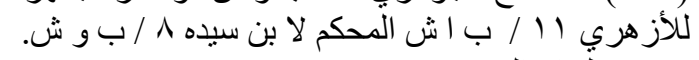

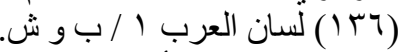

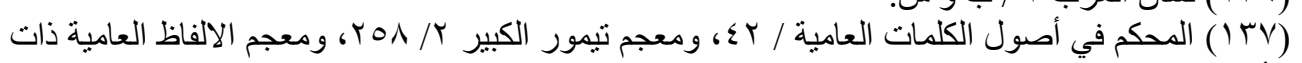

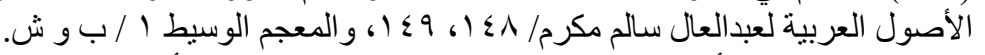

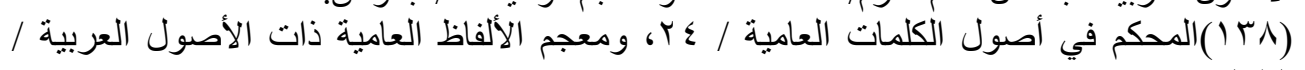

$\varepsilon$ مجلة بحوث كلية الآداب 
ما نسبه الزبيدي في تاج العروس إلى اللهجة المصرية

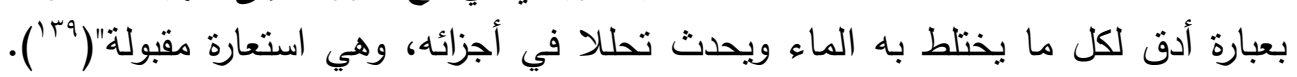

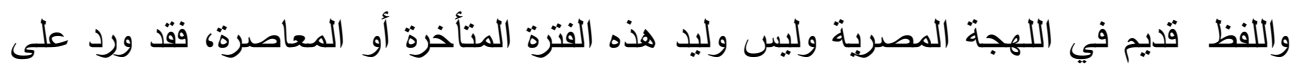

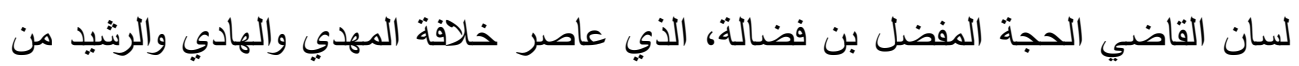
خلفاء بني العباس، والمتوفى سنة إحدى وثمانين ومائةه، وكان قاضيا لأهل مصر ، يقول: من أراد أن يأكل من بوش مصر فليأكل من بوشها، قال أبوعامر العبدري الحافظ: أراد

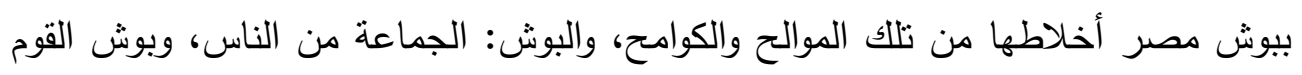

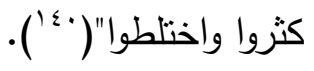

ولعله من الجائز أن تكون هذه اللفظة" البوش": طعام بمصر . . . . . نسبة إلى قرية

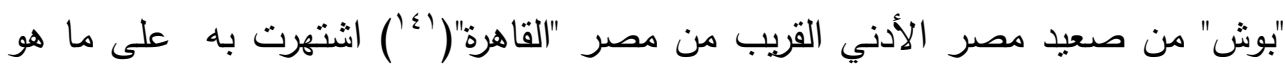
معروف من شهرة إقليم الصعيد في إنتاج العدس وغيره من سائر الحبوب علما بأن هذه منه

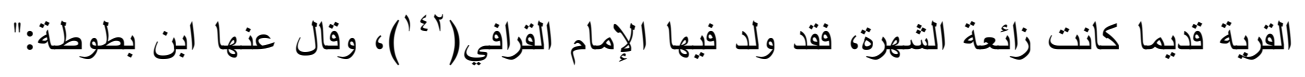

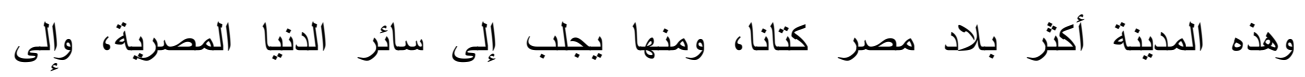

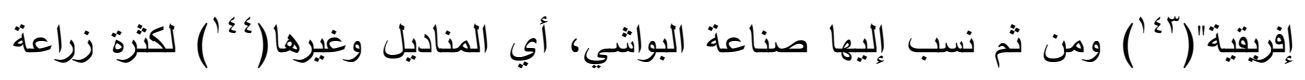

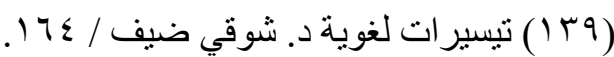

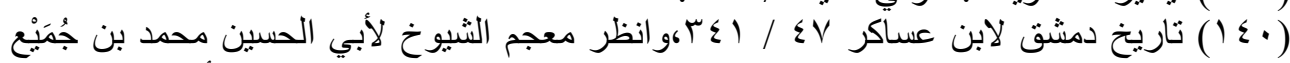

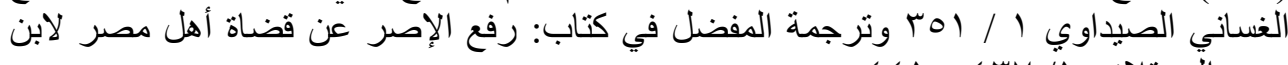

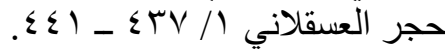

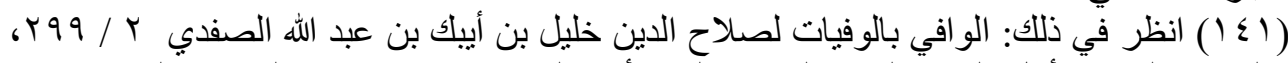

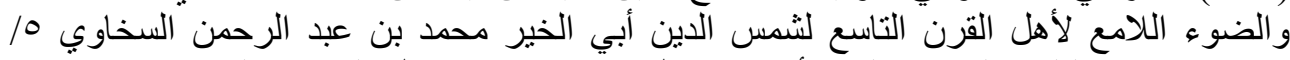

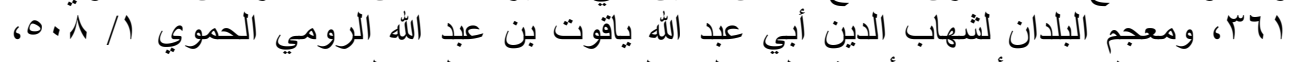

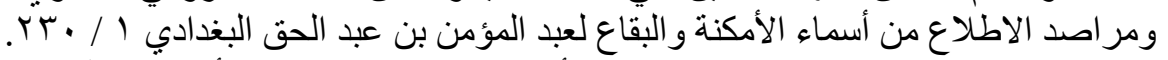

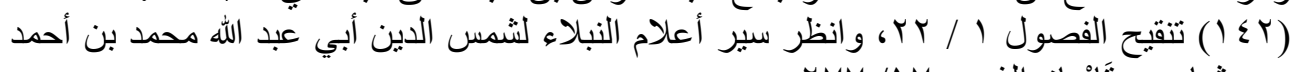

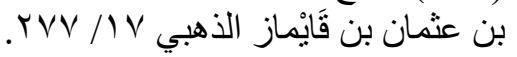

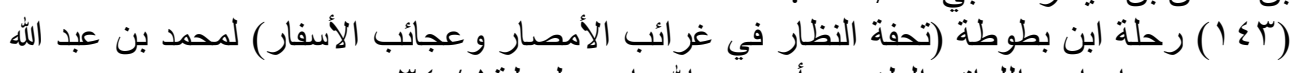

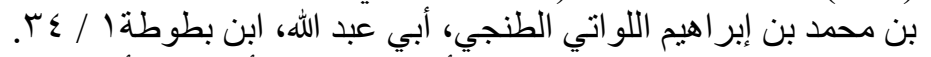

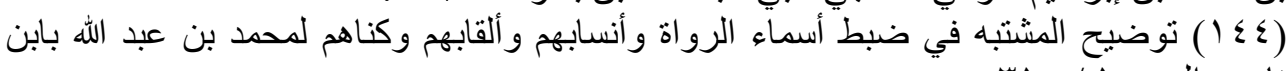

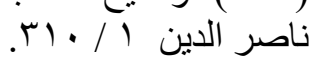


د/ مصطقى عبد الهادي عبد الستار محمد

الكتان فيها. يقول عنها الزبيدي:" وبوش بالضمائم: قرية بمصر من أعمال البهنسا، ينسب

$$
\text { إليها ثناب بوشية تجلب إلى مصر وأعمالها"( }
$$

فكما جلبوا منها الثياب جلبوا منها طريقتهم وصنعتهم في هذا النوع من الطعام،

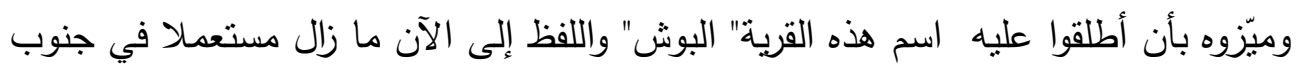
مصر الأقصى إن صح التعبير حيث السودان، أو إفريقية على نحو ما صرح به ابن بطوطة النه في كلامه السابق، فأهل السودان بطلقون البوش على فنّة تعمل من الفول، وهي أكلة مشهورة عندهم تصنع في صحن كبير كميّات من الخبز المقطع المبلل بماء الفول، والعديد من المحسنات من قبيل الطعمية والبهارات( بـ (1).

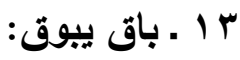

اكتسب هذا الفعل دلالة جديدة في اللهجة المصرية وإن ارتبطت بأصل دلالته في

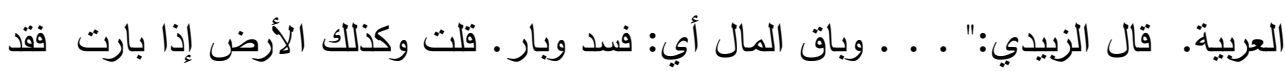

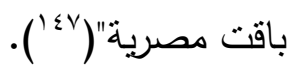
ولم أقف على نسبة هذه اللهجة إلى أهل مصر ، وإن كان الفصيح من كلام العرب

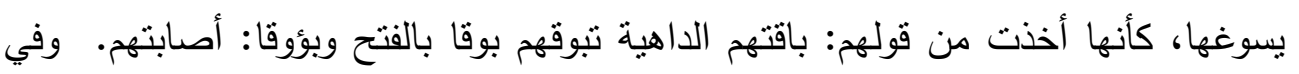
الحديث: لا يدخل الجنة من لا يأمن جاره بوائقه(^^).قال الكسائي، وغيره: بوائقه: غوائله وشره وظلمه وغشمه، ويقال للداهية والبلية نتزل بالقوم أصابتهم بائقة، وباقت السفينة بوقا:

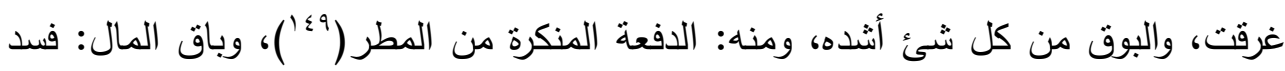

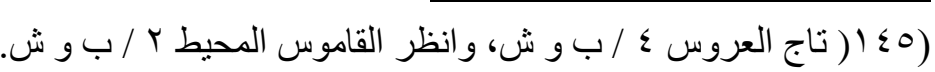
https://ar. wikipedia. org/wiki/ > http://www. blue-nil. ) (l $\leqslant$ ( ) .(net/vb/archive/index. php/t-65419. html

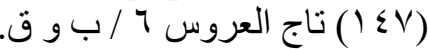

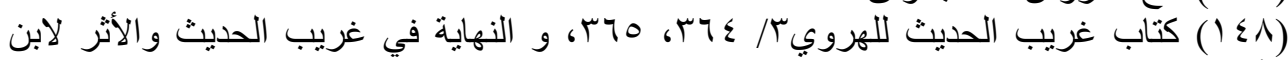

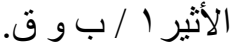

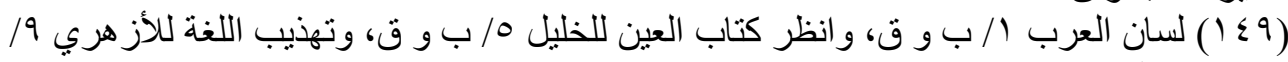

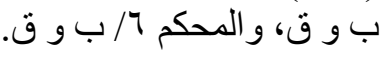




\section{ما نسبه الزبيدي في تاج العروس إلى اللهجة المصرية}

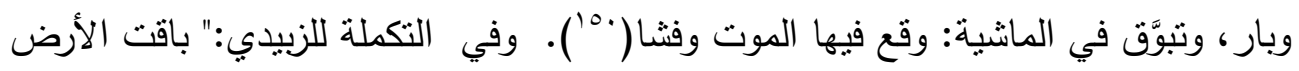

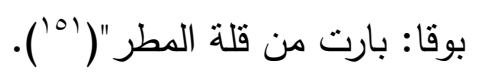

وهنا ربط الثيخ بين المعنى المصري ودلالته الأصلية في العربية الفصيحة، ولعلك

تلحظ كيف انتقل هذا اللفظ بدلالته العربية القديمة من البوقة: الدفعة من المطر إلى الأرض ولى الإديه البور، وكأنها لثدتها وما يصحبها من أصوات الرعد والبرق شبهت بصوت البوق، فقالوا: بوقة، ثم تطورت دلالة اللفظ، فقالوا للأرض التي تحرم من المطر فنبور وتفسد بوقة، مجازا إذ الأرض محل المطر ومستودعه، وهو معنى عرفته العرب قديما وخاطبهم القرآن الكريم

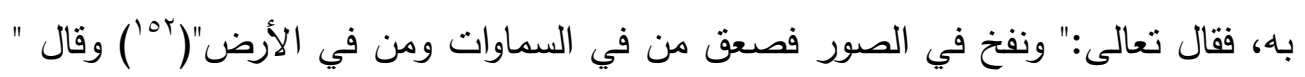

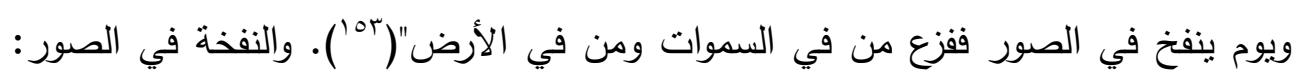
صيحة شديدة في قرن منل البوق يفزع منها الخلق ويصعقون لثدتها، ومن هذا المعنى لهن الحسي عندهم تفرعت سائر معاني المادة الدالة على الثدة والهلاك والفساد. وفي لسان لهان

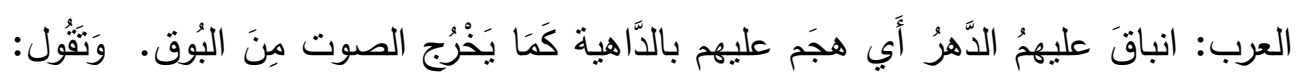

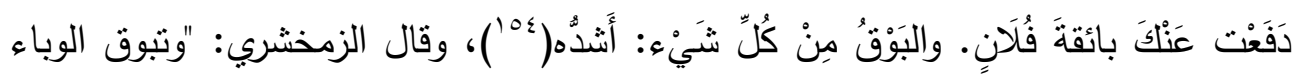

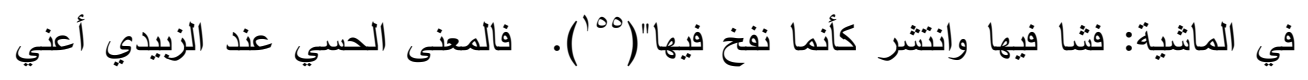
الدفعة من المطر المصحوب بصوت يشبه صوت البوق وشدته ملحوظ في المعنى المصري، كأن الأرض نفخ فيها ففسدت وبارت.

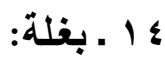

استدرك الزبيدي على الفيروزآبادي هذا التركيب اللغوي المجازي:" ومن المجاز تقول أهل مصر : اشترى فلان بغلة حسناء أي جارية، وفي بيت فلان بغال"، وانشتريت من بغال

و (10) القاموس المحيط س/ ب و ق، و انظر أساس البلاغة للزمخشري / / ب و ق، و والتكملة و الذيل

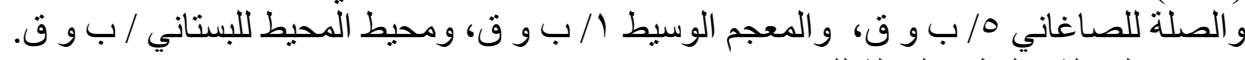

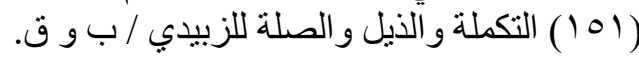

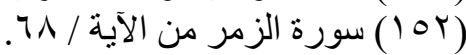

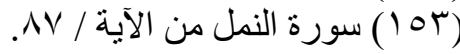

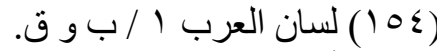
(100) (100) أساس البلاغة الرنب / / بو قو ق. 


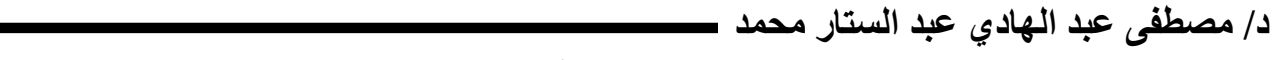
اليمن ولكن بغالي الثمن(107). وفي التكملة له أيضاً قال الزبيدي:" الثترى فلان بغلة التهلة حسنة،

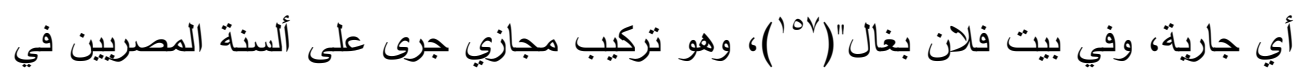

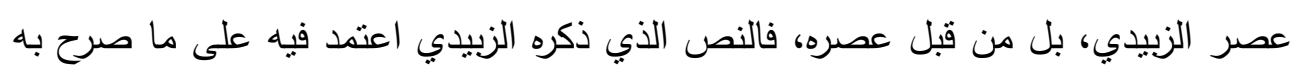

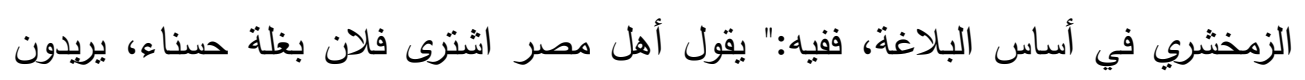

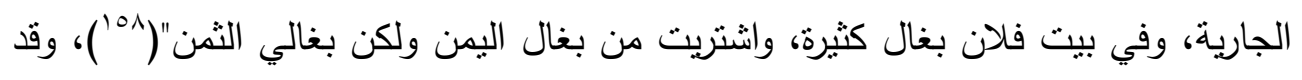
قال الجاحظ في كتاب البغال: البغلات: جوارٍ من رقيق مصر نتتج بين الصقالبة وجنس آخر ، والواحدة بغلة، وسمع بعضهم من يقول: أنثتري بغلة أطؤها فاستحمقه، ثم حكاه لآخر فقال: عفالك الله ما منا إلا من ينكح بغلة فاستغربه ففسر له، وفي بني ثغلب رأس البغل:

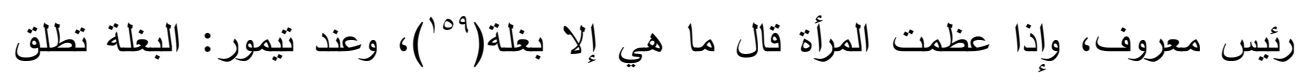
عندهم على العاقر، وتطلق أيضاً على البنت التي تأخر إدراكها أحياناً (.71).

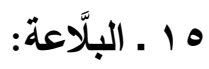

يقال: بلعت الطعام والشراب أبلعة: أي أدخلته حلقي وجوفي، وهو المعنى ومصدره

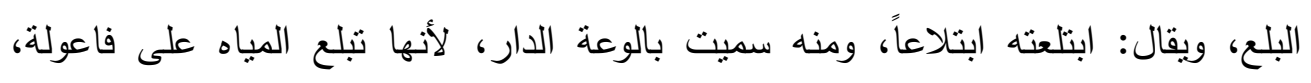

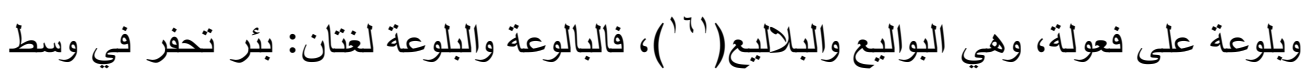

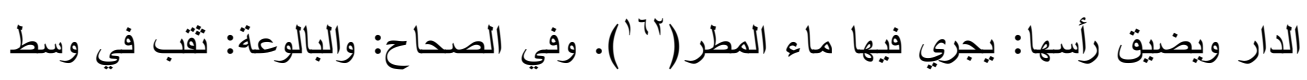
الدار وكذلك البلوعة والجمع البلاليع(rآ').

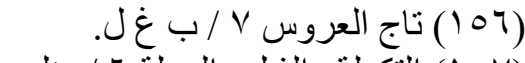

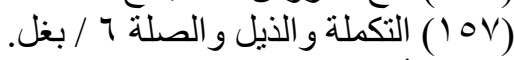

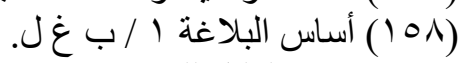

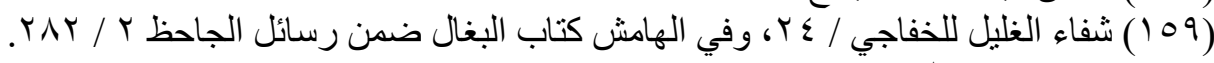

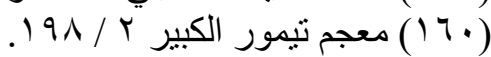

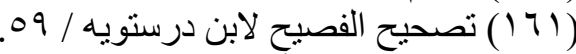

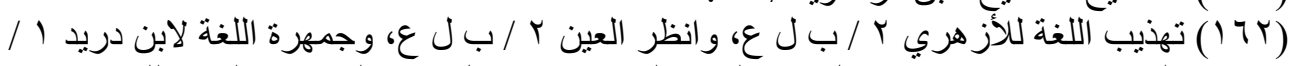

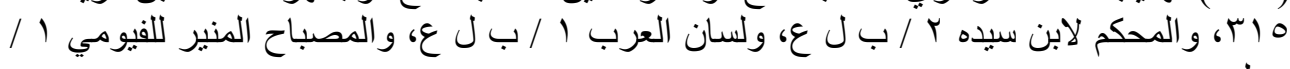

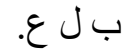
(با (1) الصحاح للجوهري ب / ب ل ع. 
ما نسبه الزبيدي في تاج العروس إلى اللهجة المصرية

هذا وقد عرفت العامية المصرية صيغة أخرى غير هاتين الصيغتين المسموعتين

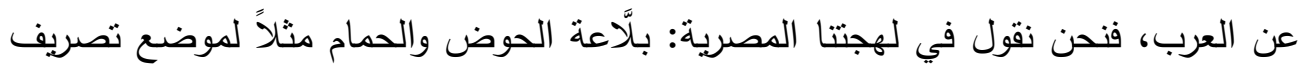

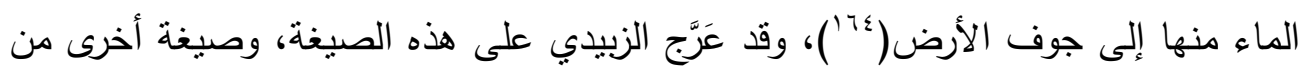

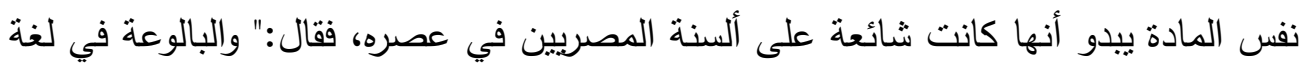

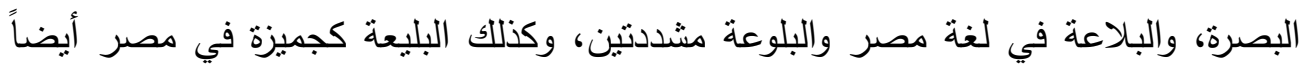

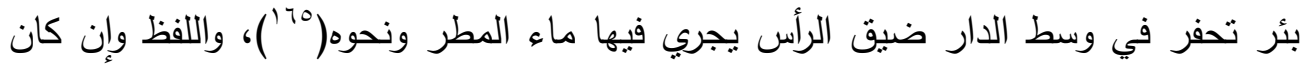

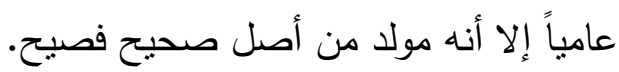

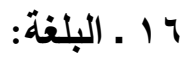

البلغة نوع من الأحذية يلبسه المصريون، وقد نصنّ الزبيدي على أن ذلك مما ولده

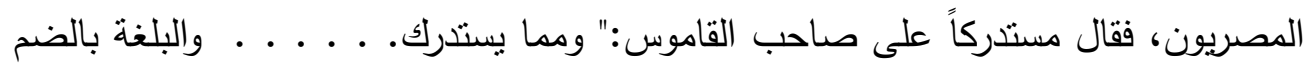
مداس الرجل مصرية مولدة"(77').

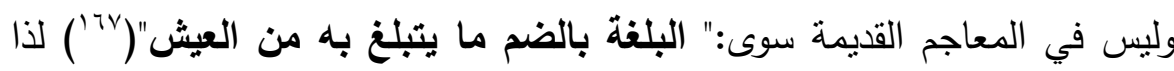

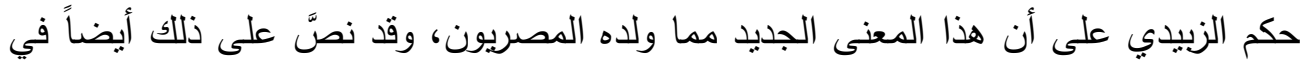

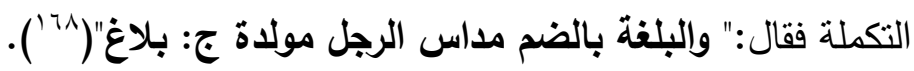

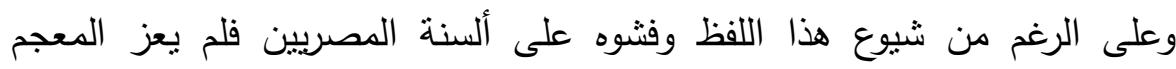

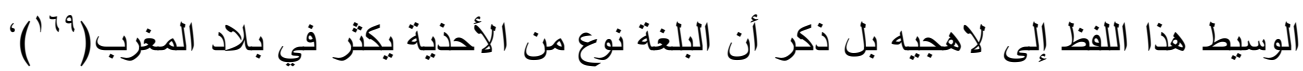

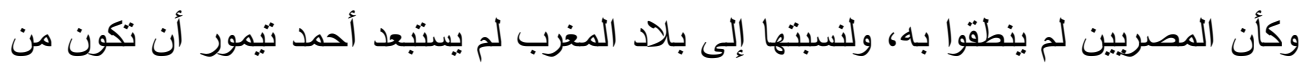

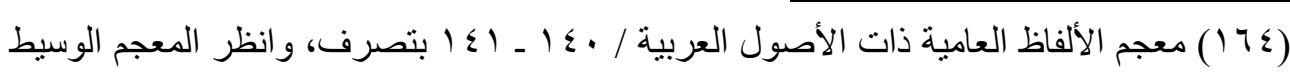

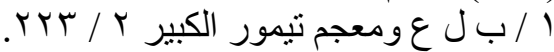

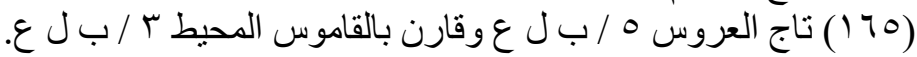

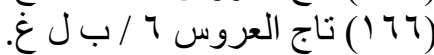

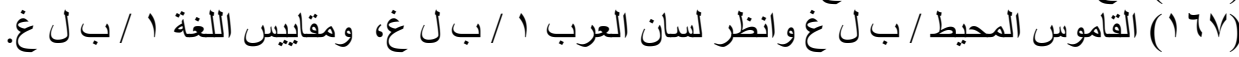

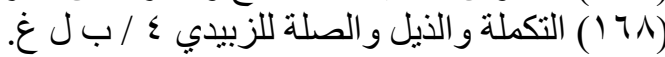

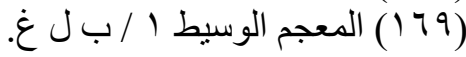

مجلة بحوث كلية الآداب

$\varepsilon 0$ 
د/ مصطقى عبد الهادي عبد الستار محمد

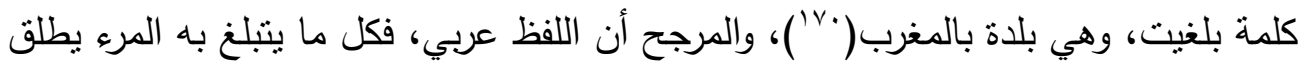
عليه بلغة. IV قال الزبيدي:" البهار : شيء يوزن به وهو ثثلاثمائة رطل قاله الفراء وابن الأعرابي، وروي عن عمرو بن العاص أنه قال: ابن الصعبة يعني طلحة ابن عبيد الله نرك مائة بهار

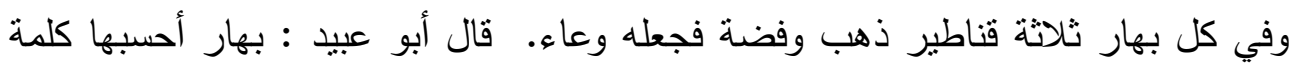
غير عربية وأراها قبطية( وعليه : فالبهار بالضم مما اختلف فيه وإن نطق به الفصحاء، فقيل: حمل أو

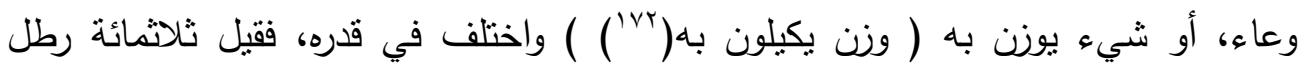
بالقبطية، وقيل أربعمائة رطل، وقيل ستمائة رطل، وقيل ألف رطل، وظنهاء ونها أبو عبيدة من اللغة القبطية، وذهب غيره إلى أن البهار عربي صحيح، وهو ما يحمل على البعير بلغة أهل

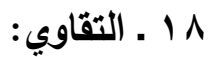

استدرك الزبيدي على الفيروزآبادي لفظ التقاوي، فنصَّ على أنه من العامية المصرية. قال: "والتقاوي اسم لما يدخر من الحبوب للزرع كأنه جمع تقوية، وهو اسم كالتمنين لغة مصرية(؟عا1). وقد عرف مجمع اللغة التقاوي بأنها بذور القطن والقمح والفول

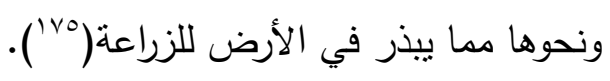

ومن الملاحظ أن الزبيدي اجتهد في محاولة رد هذا المعنى إلى أصله الفصيح وإن لم يقطع بما ذهب إليه، ويكفيه أن إثارته هذه ظلت محل نظر المحدثين في محاولتهم البحث

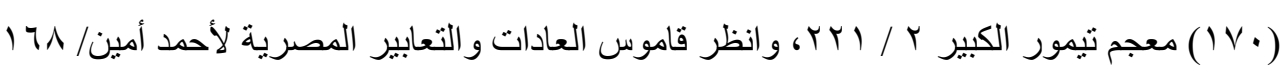
.179

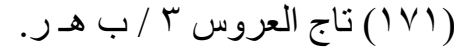

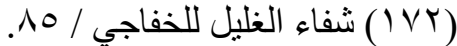

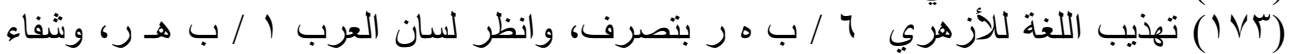

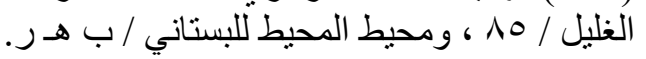

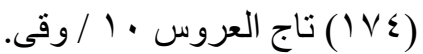

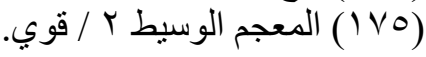




\section{ما نسبه الزبيدي في تاج العروس إلى اللهجة المصرية}

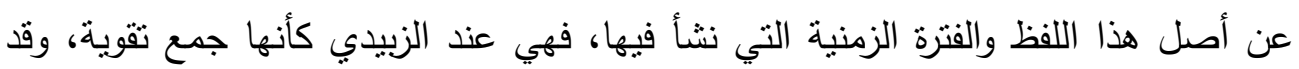
أخذ بعض المحدثين بهذا الرأي، ففي محيط المحيط:" والتقوية مصدر قوَّى، والعامة تستعملها

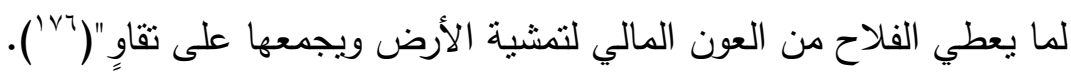
وليس في المعاجم القديمة تحت هذا اللفظ أكثر من معنى قولهم: التقاوي بين الثركاء أن يشتروا سلعة رخيصة، ثم يتزايدوا بينهم حتى يبلغوا غاية ثمنها( (IVI). أي يبلغوا بالسلعة أقوى ثمنها، وقد ذهب أحد المحدثين إلى أن المعنى العام من هذا المعنى استعاره

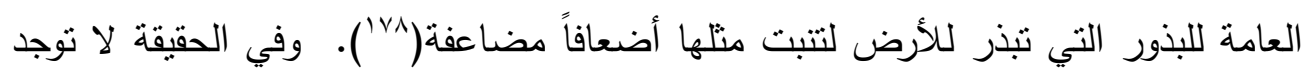

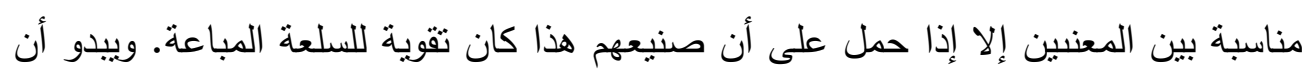
التقاوي جمع لكلمة " تقوية "، وأن البذور كانت تصرف للفلاحين من قبل السلطان تقوية لهم

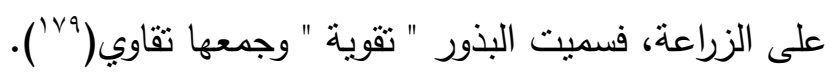
ومما ذكره الثيخ إبراهيم حمروش في هذا الصدد أن هذا الاستعمال يرجع إلى عهد

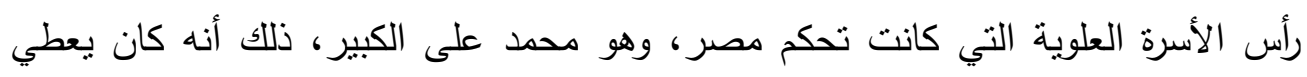

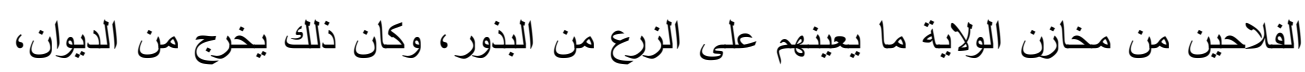
ويكتب في كتب الأعطية. يعطي فلان كذا كيلة أو إردباً تقوية له، فلما كثر قرن عطاء البذور بالتقوية وكان بينهما هذا التحالف غلبت التقوية على البذور وعرفت فيه. فكان إذا قيل: أخذت التقوية فإنما يعني أخذ البذور، وجمع التقوية على التقاوي، وغلب هذا اللفظ " لئل

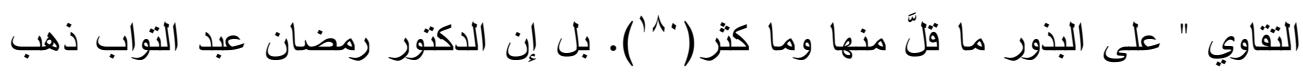

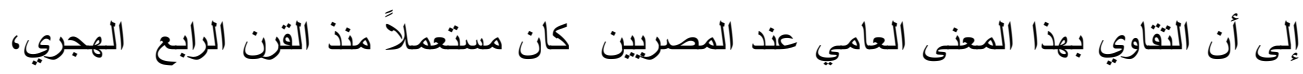

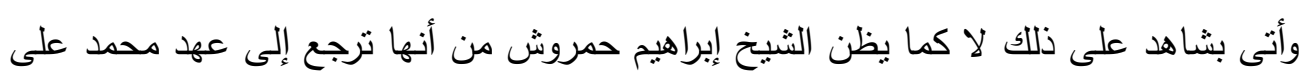

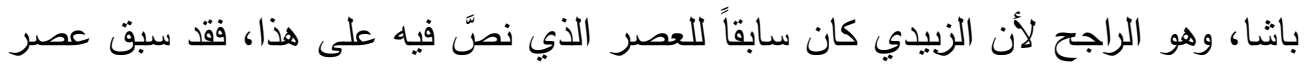
الأسرة العلوية. وبيدو أن اللفظ له علاقة وثيقة بسلطة الدولة، فالحاكم أو الوالى هو الذي لهي لهي

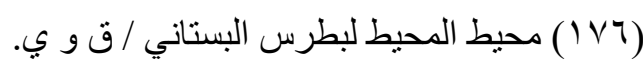

(IVV) المحكم في أصول الكلمات العامبة أحمد قيس / (IVA) (IVV)

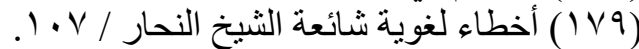

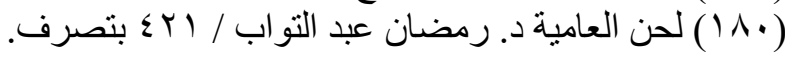


د/ مصطقى عبد الهادي عبد الستار محمد

كان يتولى ذلك، لذلك أطلق عليها اسم التقاوي السلطانية، وكانت صنفين تقاوي سلطانية، وتقاوي بلدية، وكانت تسمى في السودان التيراب. وفي المغرب: الزريعة ولم تزل تسمى بذلك ولك إلى الآن بتونس(')

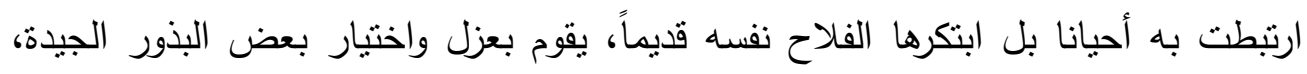

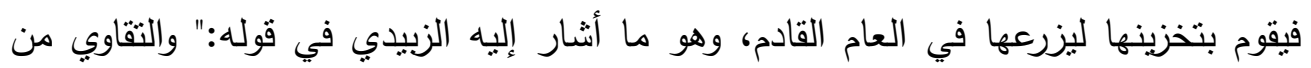
الحبوب ما يعزل لأجل البذر عامية"(

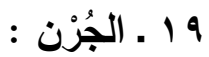

نقول في عاميتتا : الجُرْن ، وهو مكان مخصوص لجمع المحصولات الزراعية،

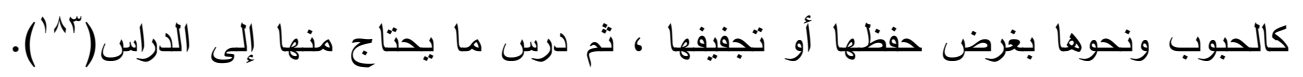

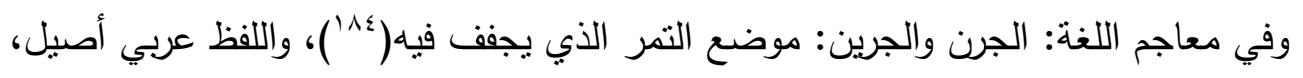
قال فيه الزبيدي:" والجرن بالضم وكأمير . . . . . . . . وقال الليث: الجرين بلغة أهل اليمن، وعامتهم يكسر الجيم وجمعه جُرُن، قلت: والأولى هي لغة أهل مصر ، ويستعملونه لبيدر

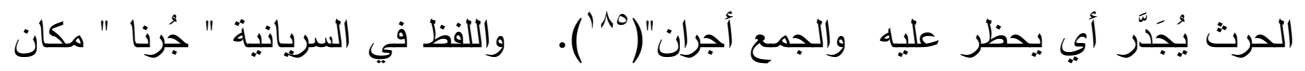

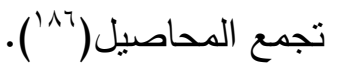

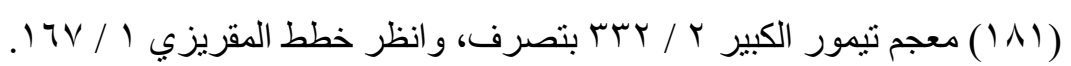
( INr)

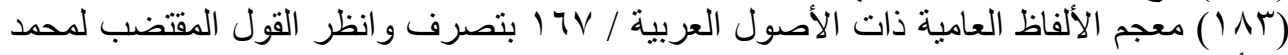

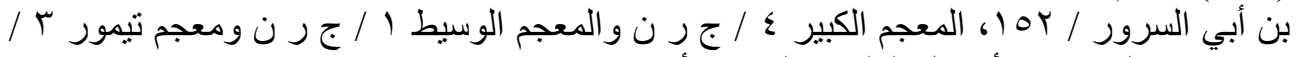

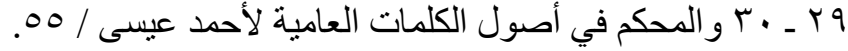

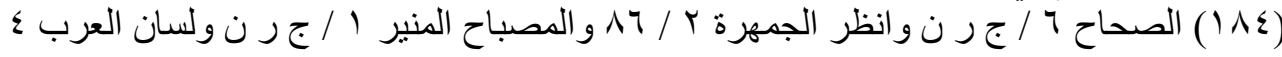

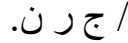

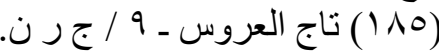

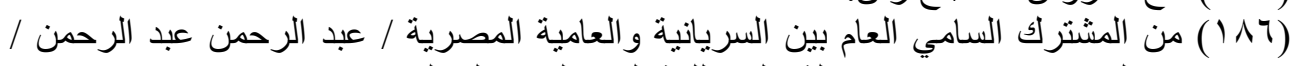

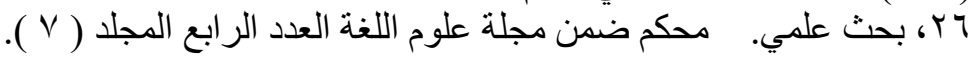


ما نسبه الزبيدي في تاج العروس إلى اللهجة المصرية

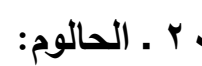

الحالوم: نوع من الجبن معروف في اللهجة المصرية، وقد نصنّ عليه الثيخ

الزبيدي، فقال:" والحالوم: ضرب من الأقط عن ابن سيده، أو لبن يغلظ فيصبر شبيها

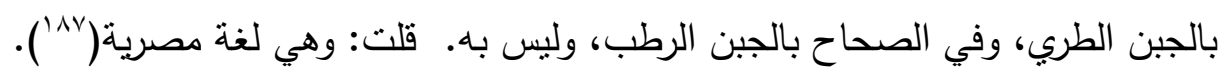

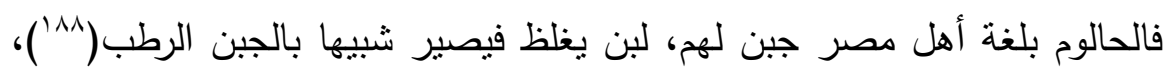

وليس بـ(199)، وضرب من الأقط، أو لبن محمض يجمد حتي يستحجر ويطبخ به( (9'1).

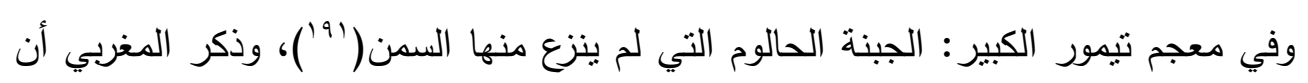

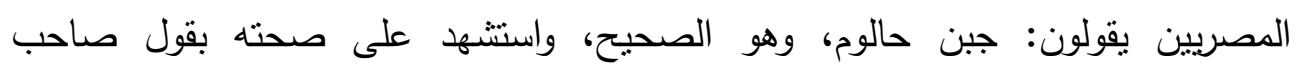

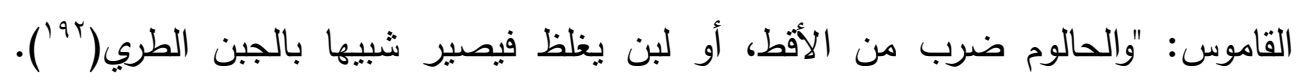
وذهب بعضهم إلى أن أصل اللفظ من المصرية، ومن كلام البائعين" " حالوم يا جبنة، جبنة

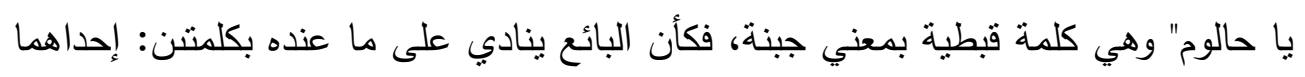

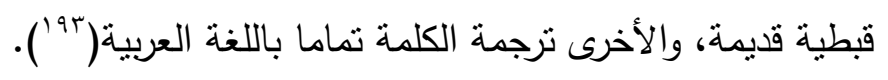

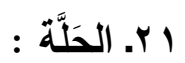

قال الزبيدي:" والحلَّة في اصطلاح أهل بغداد كهيئة الزنبيل الكبير من القصب يجعل فيه الطعام، نقله الصاغاني. قلت: وفي اصطلاح مصر بطلق على قِدْر النحاس، لأنه

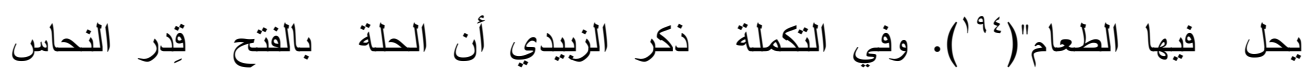
مصرية(190).

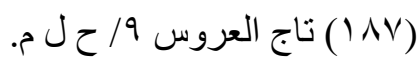

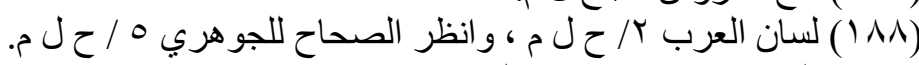

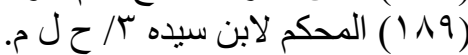

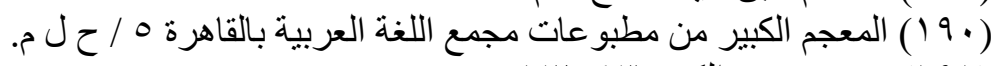

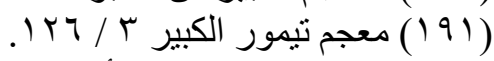

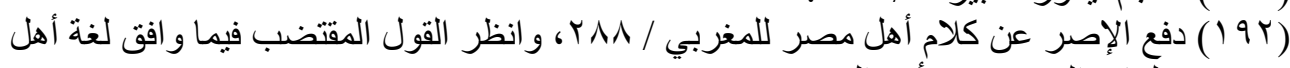

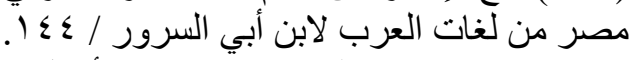

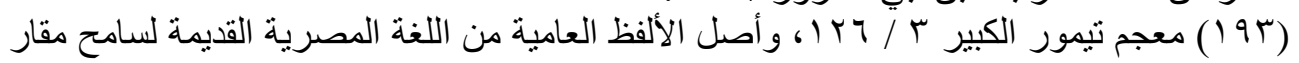

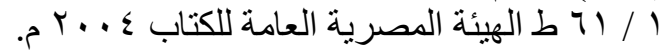

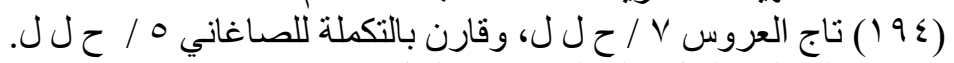

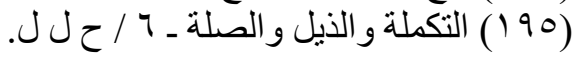


د/ مصطفى عبد الهادي عبد الستار محمد سله

وعليه فالحلة: زنبيل أي وعاء كبير كان يصنع من قصب معب عند البغداديين يقابله في اللهجة المصرية قدر أو إناء من نحاس، وقد ذكر المعجم الوسيط أن الحلة زنبيل كبير من قصب يجعل فيه الطعام، وإناء معدني يطهى فيه الطعام محدثة(97'). وبالملاحظة يتبين

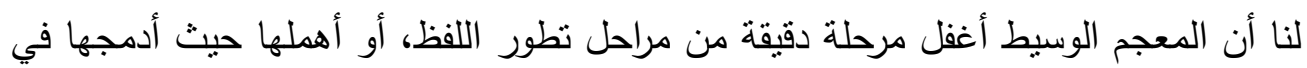

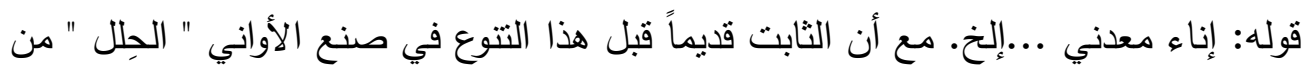
معادن مختلفة اتخاذها من نحاس على ما هو مشهور ومعروف إلى عهد قريب جداً في القطر المصري، فكان الأولى أن يفردها في النص على ما ذكر الزبيدي في اللهجة المصرية، ثم يتبع ذلك بما صرح به في هذا الصدد، ونظرت في المعجم الكبير لعلى ألحظ

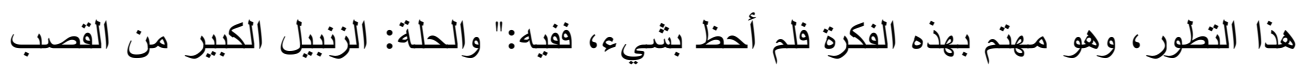

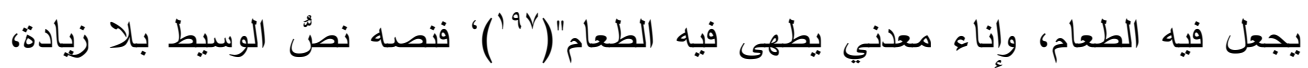

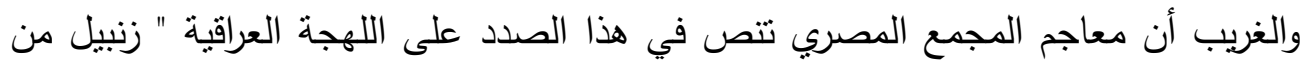
القصب " إلخ. للك التي صرح بها الزبيدي عن الصاغاني، وتهمل اللهجة المصرية الموازية لها على أقل تقدير في عهد الزبيدي، بل إلى عهدنا "القدر من النحاس" وظاهر الأمر أن

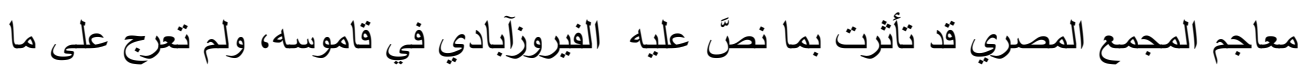

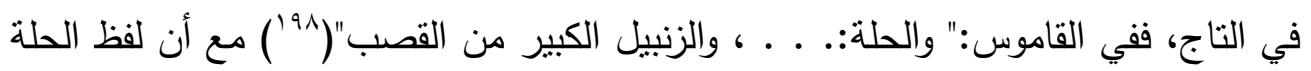
بمعناه العراقي والمصري من العامي، إذ لم أعثر على نصٍٍ في المعاجم القديمة بصرح بأن الحلة:" الزنبيل الكبير من قصب" من نطق الفصحاء، فقبده هكذا في الوسيط والكبير وإفراده دون المعنى المصري القديم تعسف. وفي معجم تيمور :" حلة الأكل هي القدر من النحاس عندهم. . . . . . . . والحلة:

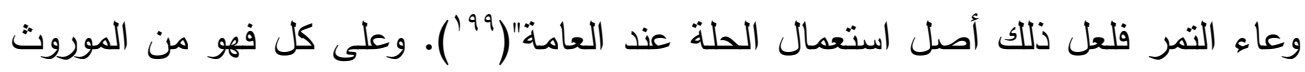
السامي القديم إذ اللفظ في السريانية " حلتا "( .بr).

(197) (197) المعجم الوسبط / / / ح ل ل ل. (19)

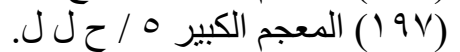

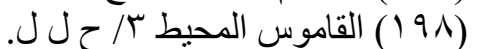

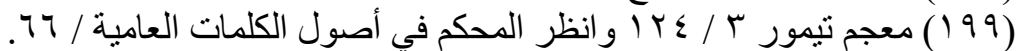

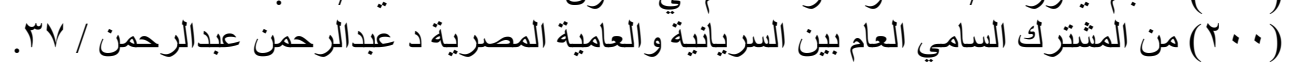


ما نسبه الزبيدي في تاج العروس إلى اللهجة المصرية

Y r ـ الحندويل:

استدرك الثيخ الزبيدي على صاحب القاموس لفظ الحندويل بمعناه العامي المصري.

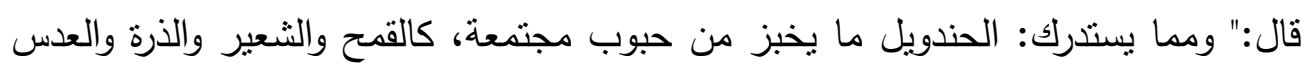

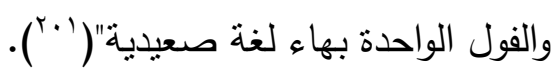

ولم أقف على هذا اللفظ بمعناه في المعاجم القديم، فغاية ما ذكر في مادته:

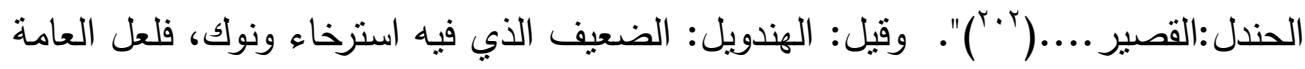

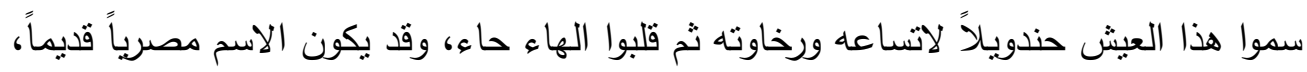

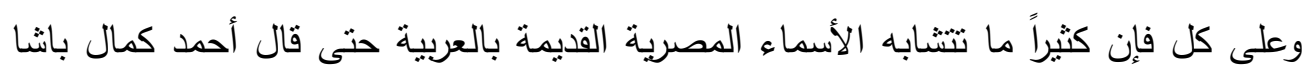

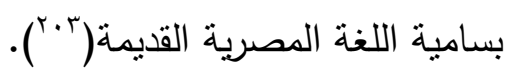

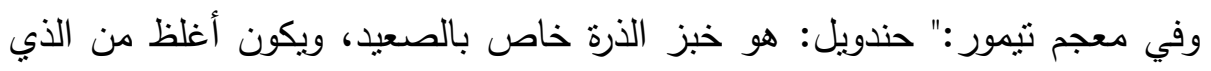

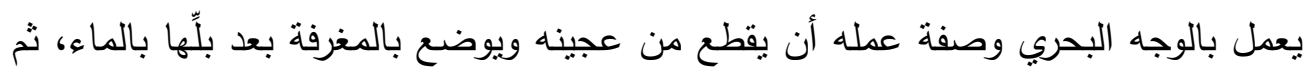

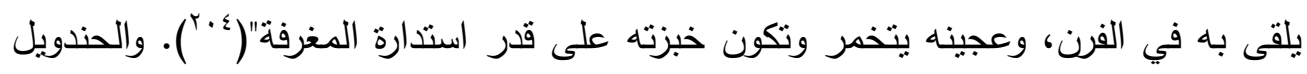

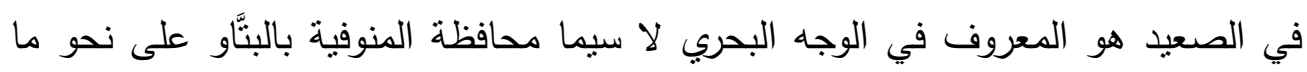

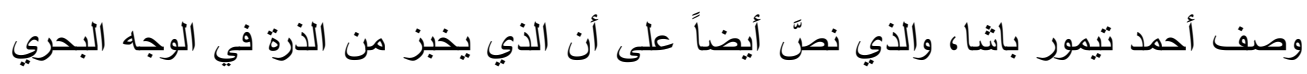

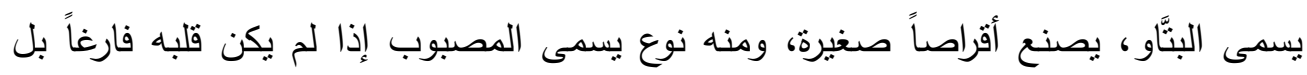

$$
\text { مصبوب صباً (r.0 (r.0). }
$$

بr ـ الحوش:

في العامية المصرية الحوش بضم الحاء: الفناء(ب+r+r)، فناء الدار ونحوها أو حظيرة

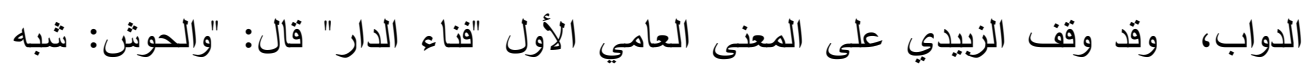

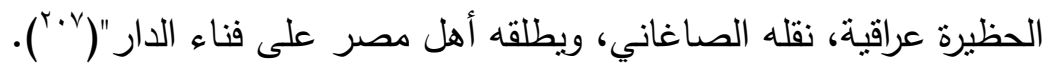

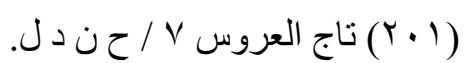

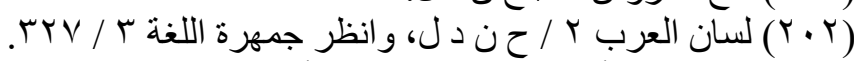

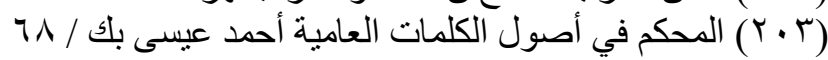

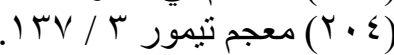

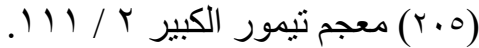

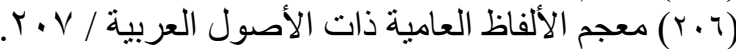

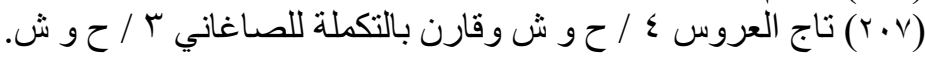




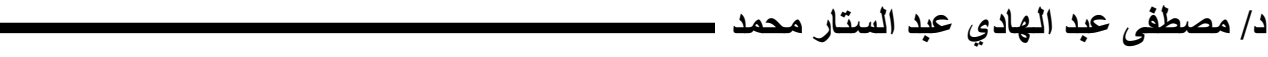

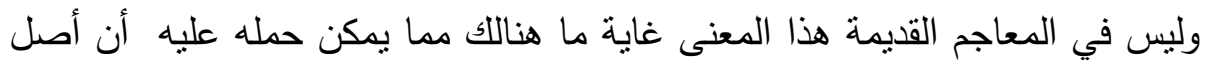

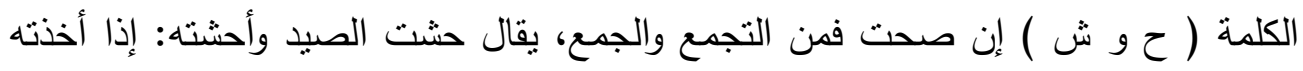

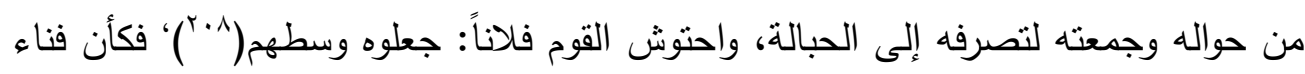

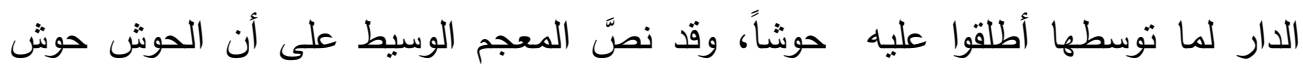

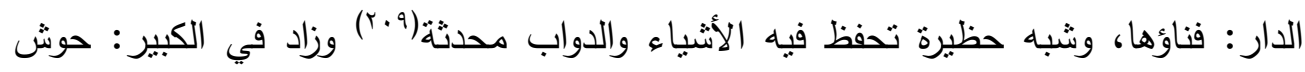

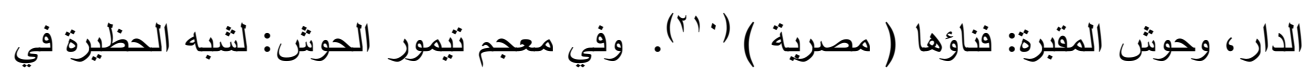
العراق، وحوش البيت: فناء الدار وصحنها،. . . . . . . . . وحوش المقابر أي الحظيرة

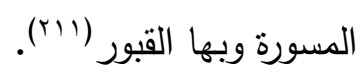

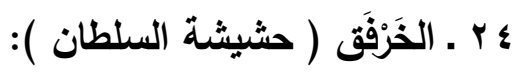

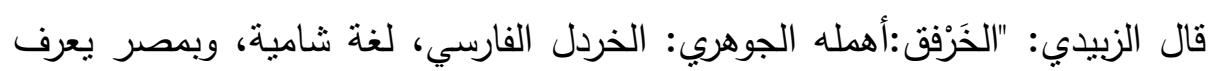

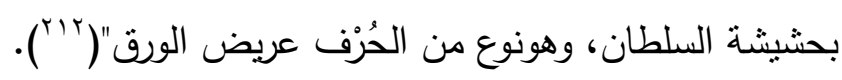
ولم يزد هنا شيئا على ما نص عليه المجد في قاموسه، فالقول قوله، وفي مادة (خ ر د ل) نقل الزبيدي أيضا عنه قوله: والخردل الفارسي نبات يكون بمصر يعرف بحشيشة

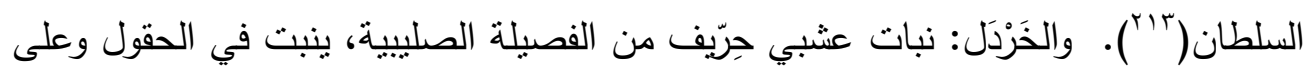

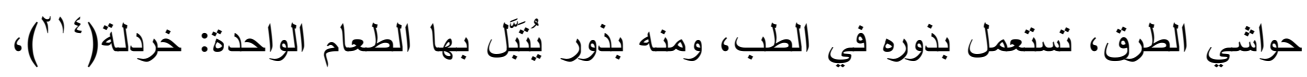
وفي معجم تيمور الكبير: والخرفق: يعني في الفارسية الخردل، وعرف في مصر بحثيشيشة

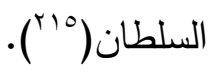

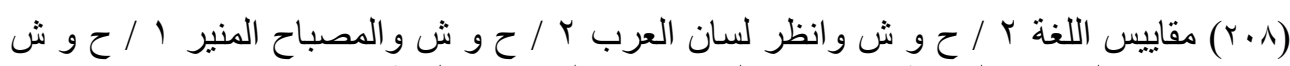

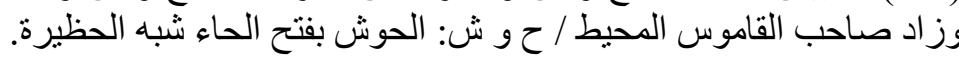

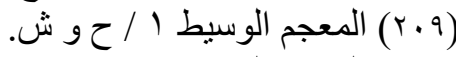

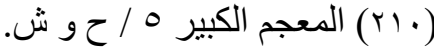

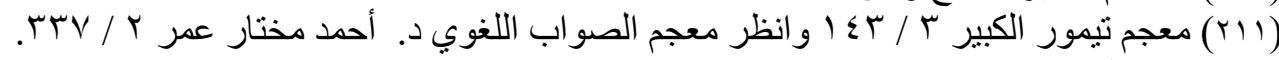

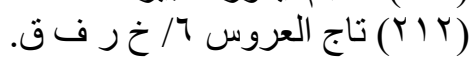

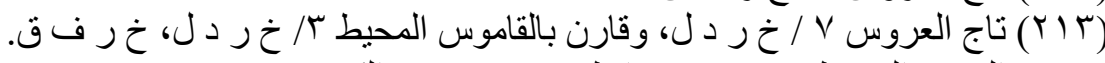

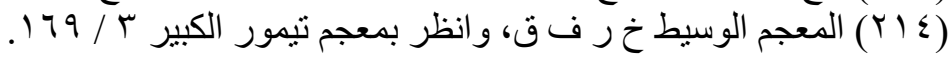

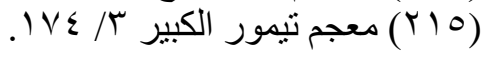


ما نسبه الزبيدي في تاج العروس إلى اللهجة المصرية

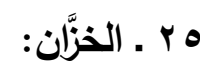

الخزَّان من خزن الشئ يخزنه خزناً واختزنه: أحرزه، وجعله في خزانة واختزنه لنفسه،

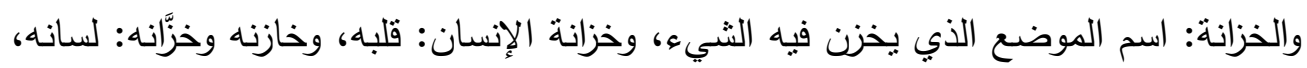

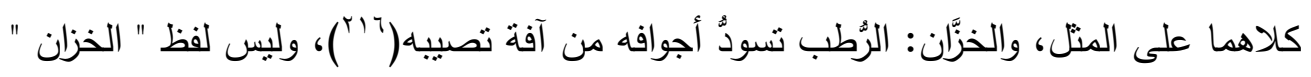

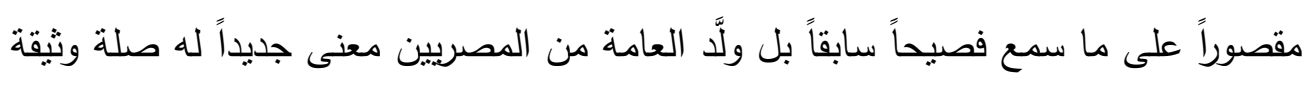
بأصل المادة ومشتقاتها، وقد عرض الزبيدي لهذا المعنى فقال:" والخزَّان كثنداد من يخزن الطعام خاصة لغة مصرية"("r|r) أي القائم على مخزن الطعام وخزانته، أو من يحتكر الطعام لتتدد الحاجة إليه، فلا ينفقه حتى يغلو سعره ويتجاوز قدره، وتعريف الزبيدي " من يخزن

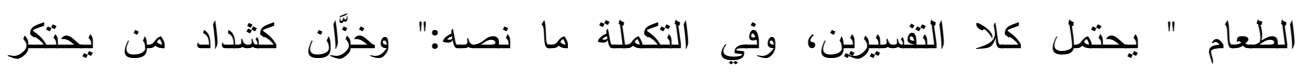

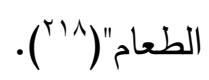

هذا ولم تعرج المعاجم القديمة على هذا المعنى المصري المنصوص عليه عند

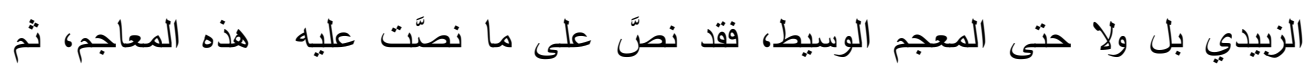

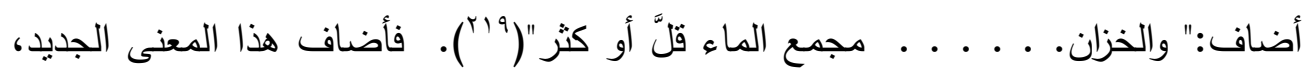
وأهمل المعنى الذي نحن بصدده، بيد أن معجم تيمور الكبير ذكر أن الخزان:" خازن الطعام، أي القمح ونحوه .. والخزان بناء كالحوض لخزن الماء، يرادفه المصنع"( بr.ب).

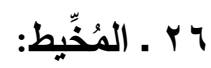

المخيط كجميز لهجة مصرية في لفظ " المخاطة "، والمخاطة: شجرة ثثر ثمراً حلواً

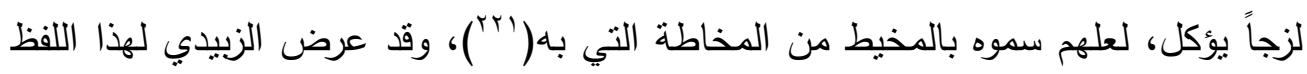
بمعناه العامي المصري، فقال في شرحه على قول الفيروزآبادي:" والمخاطة كثمامة وجميز : شجر فارسيته: " الستِّبتان " والمخاطة كثمامة عن أبي عبيدة وبعض أهل اليمن يسميه

$$
\begin{aligned}
& \text { (Y) } \\
& \text { (Y) }
\end{aligned}
$$

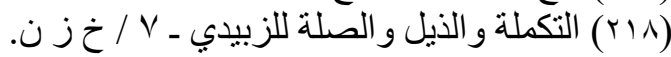

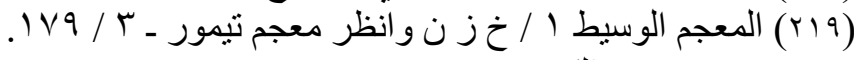

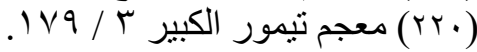

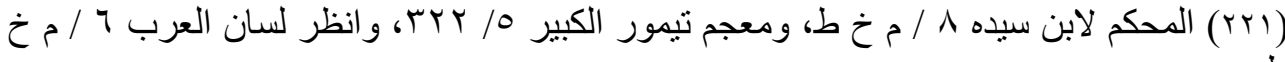




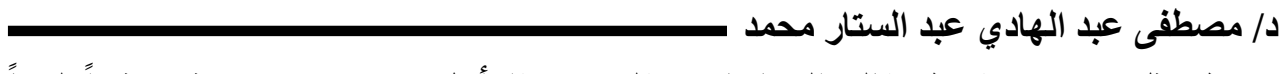
المخيط مثل: جميز وقبيط، قاله الصاغاني. قلت: وكذا مُأ أهل مصر : شجر يثمر ثمراً لزجاً يؤكل فارسيته : السبستان( وهذا النوع من الثجر من الفصيلة المخاطية لها ثمر مخاطي كان يستعمل لتليين

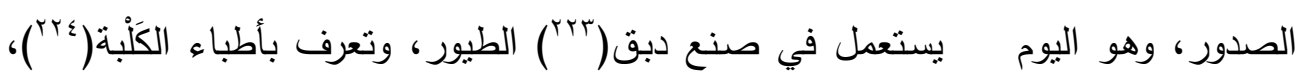
وهي النوع التي تسميها الفرس سبستان، أصله الفارسي سبستان، وهو تخفيف سك بستان أي

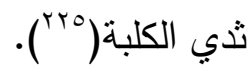

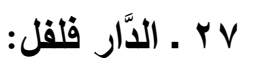

نص صاحب القاموس المحيط على أن الدار فلفل هو شجر الفلفل أول ما يثمر، وزاد الزبيدي في الثرح النص على اللهجة المصرية فيه، فقال:" قلت ويعرف الدار فلفل بمصر بعرق

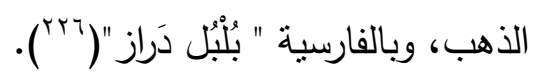
وهو إلى الآن معروف عند العطارين والعامة بما صرح به الزبيدي في تسميته "عرق لهاب الذهب"، وهو حار يضاف إلى الكُحْل، وفي معجم تيمور الكبير :" عرق الذهب: وهو دار

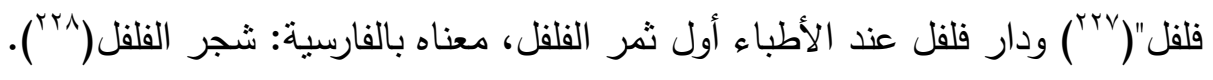

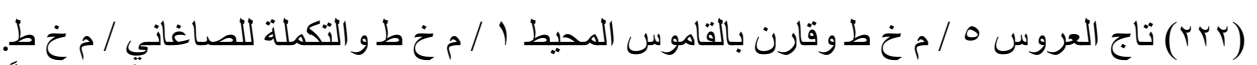

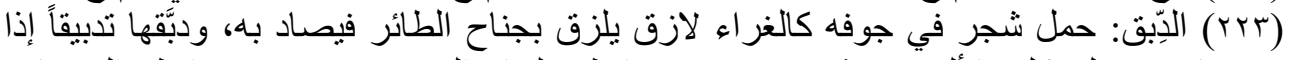

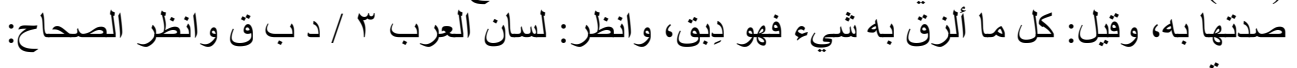

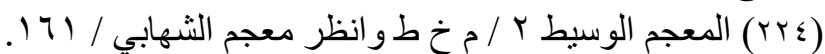

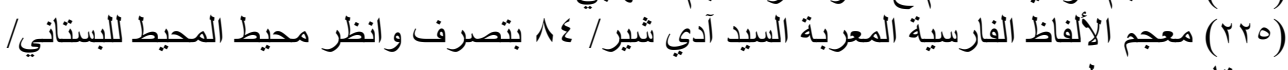

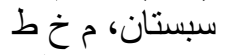

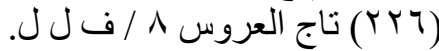

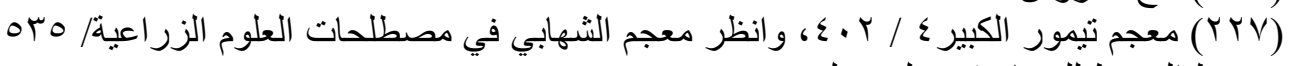

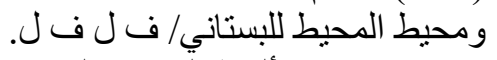

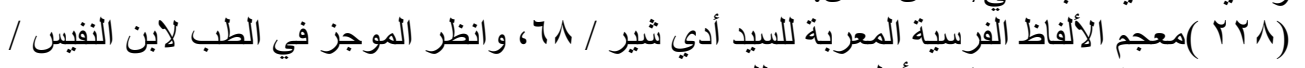

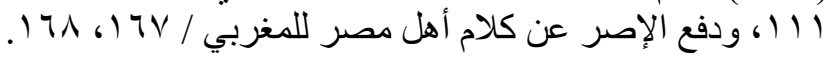

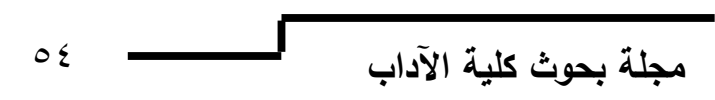


ما نسبه الزبيدي في تاج العروس إلى اللهجة المصرية

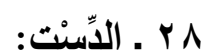

في العامية المصرية يطلق الدّّت على إناء أو وعاء من نحاس معروف، وقد ورد

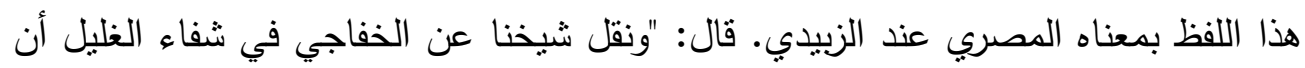

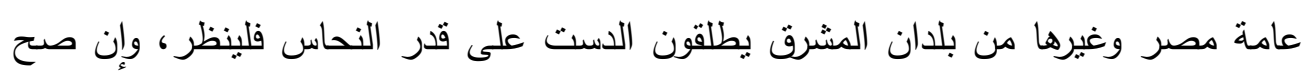

$$
\text { فيستدرك به على المؤلف"( و (rq). }
$$

وكأن الزبيدي الذي صال وجال في أنحاء القطر المصري، وخالط عامتهم وخاصنهم

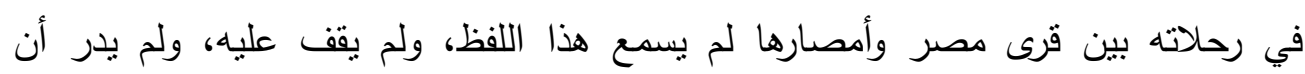

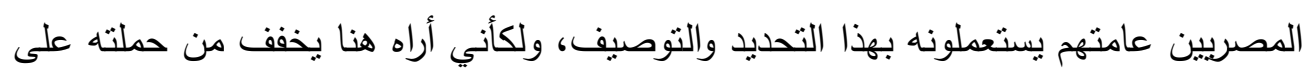

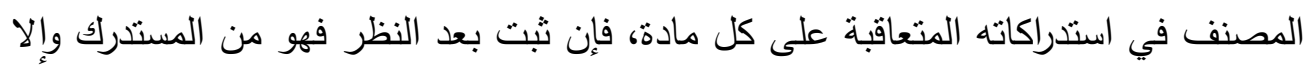

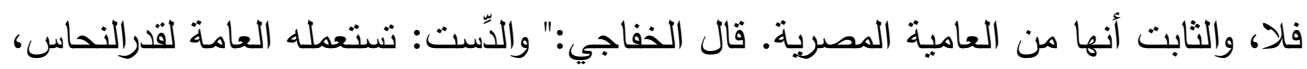

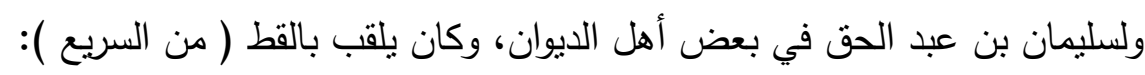

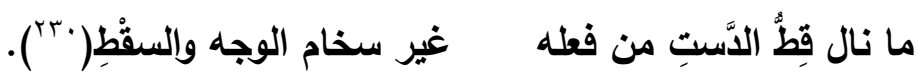

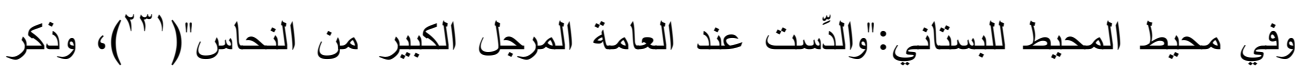

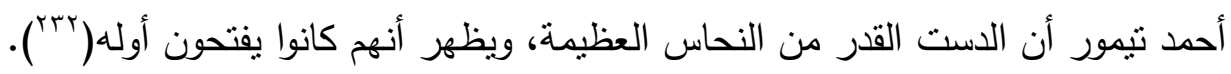

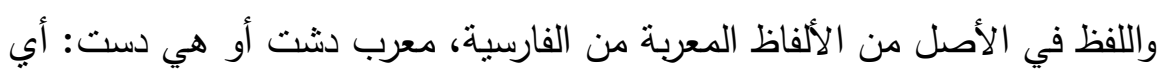

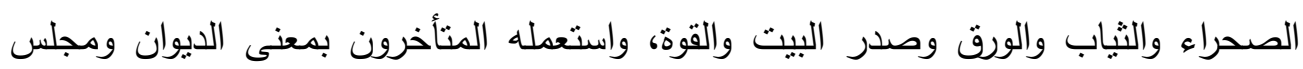

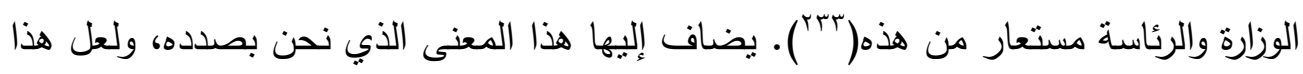

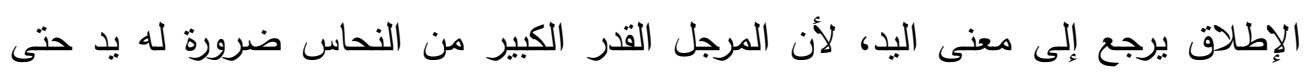

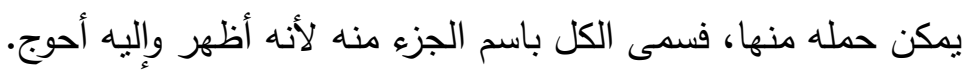

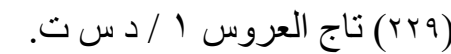

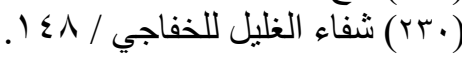

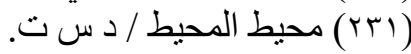

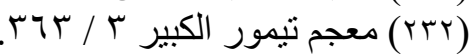

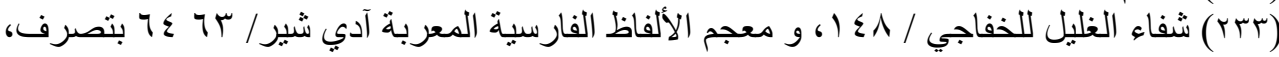

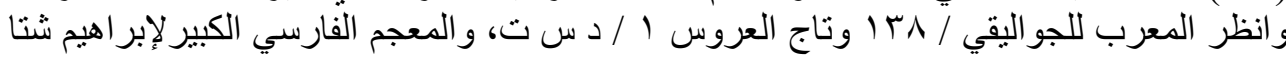


د/ مصطفى عبد الهادي عبد الستار محمد

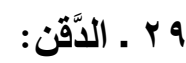

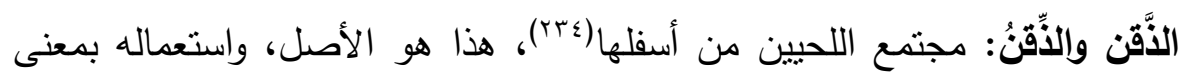

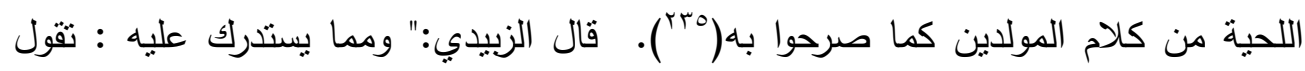

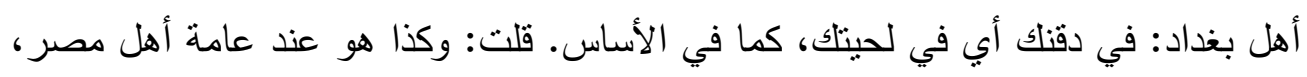

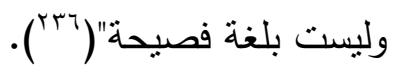

فالعامة(بr/ تلاعبت بهذا اللفظ من جهتين: الأولى: من جهة النطق فتبدل الذال دالاً للتقارب في المخرج، والاشتراك في بعض الصفات، والثانية من جهة المعنى فنطلق على الأى هن

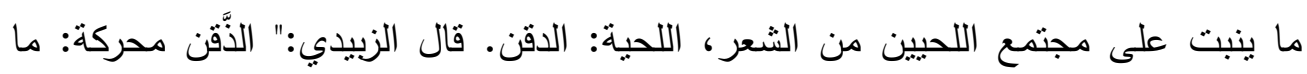

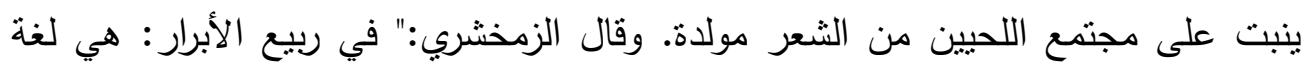

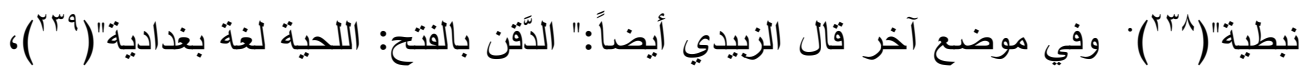

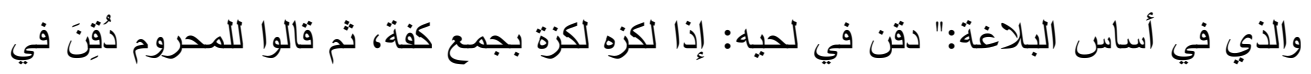

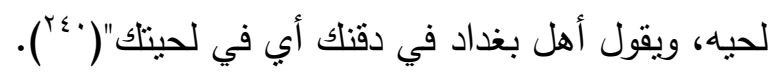

فهذه اللهجة لم تكن شائعة عند المصريين فحسب بل كانت مستعملة عند البغداديين والأنباط على السواء، ومما بدل على عروبتها أنها من المشترك السامي ففي الأجاريتية،

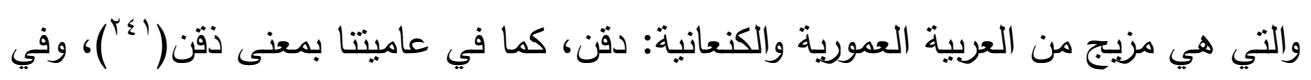

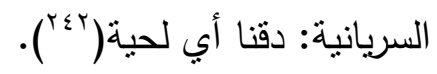

(

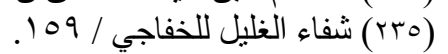

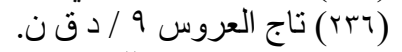

(rTV)

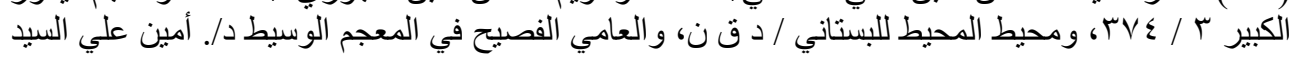

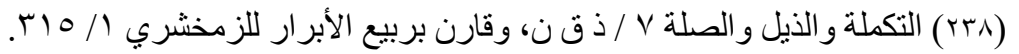

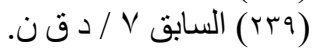

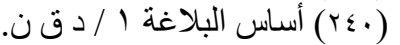

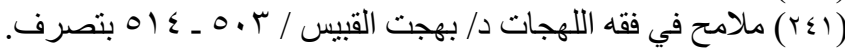

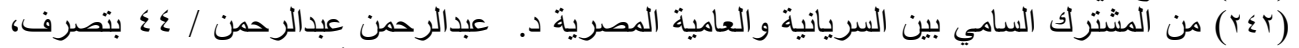

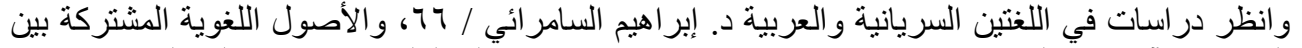

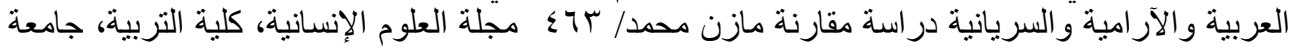

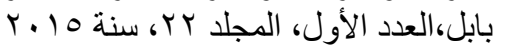




\section{ما نسبه الزبيدي في تاج العروس إلى اللهجة المصرية}

\section{. ب ـ الاموية :}

على عهد الزبيدي وفيما قبل عصره كان المصريون يطلقون على حُمَّى الدّقّ، وهي

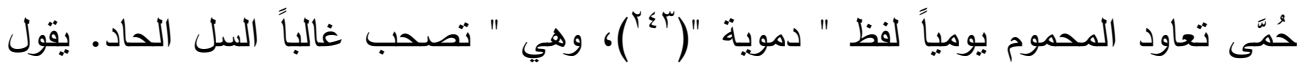
الزبيدي مستدركاً على صاحب القاموس المحيط: "وتصغير الدم: ذُمي، والنسبة إليه ذُمي

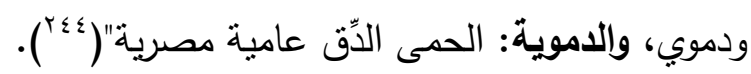

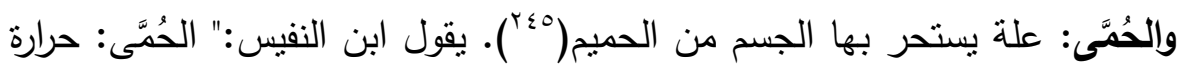

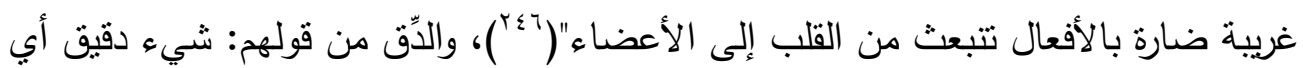

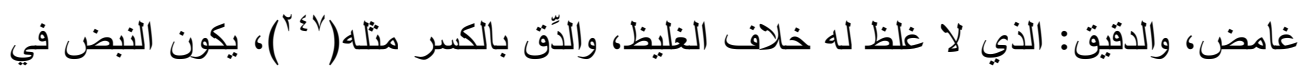

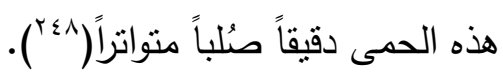
وإطلاق المصريين على هذا النوع من الحمى لفظ " دموية " لله ما يسوغه من

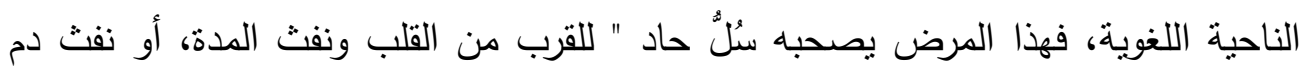

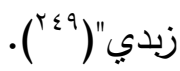

إذن فقد لاحظ المصريون ما يصحب هذا النوع من الحمى من نفث الدم فاستحدثوا

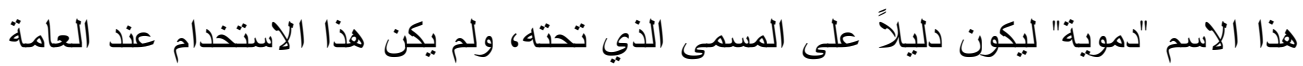

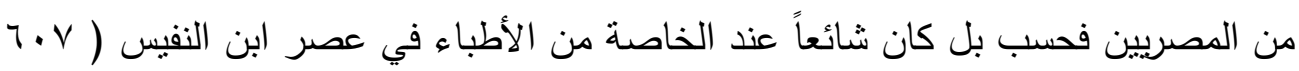

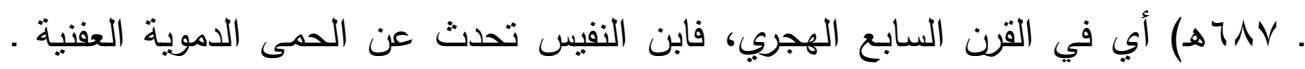
لاحظ لفظ الدموية ـ ويدل عليها عنده جملة من الأعراض منها غليان الدم من الصداع

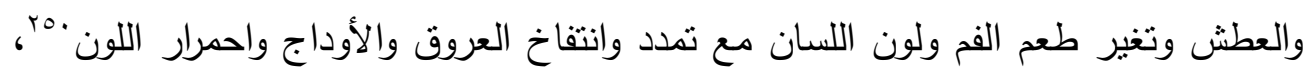

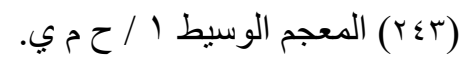

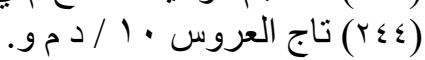

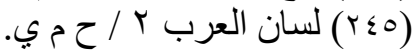

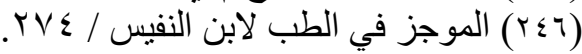

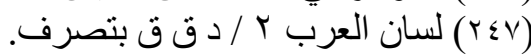

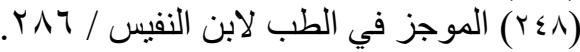

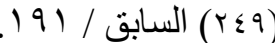

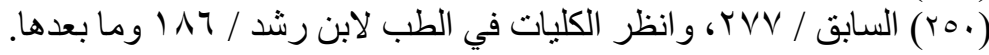


د/ مصطقى عبد الهادي عبد الستار محمد

ذلك الأخير الذي لاحظه المصريون فناسبوا بين اللفظ ومدلوله فأطلقوا عليها لفظ دموية "وكأنها مصدر صناعي صاغوه" (مب من لفظ الدم بعد رد المحذوف من الكلمة وهو ( الواو ).

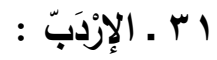

الإردَبَ أو الأردب من الألفاظ الثائعة في العامية المصرية، يطلق على مكيال معروف، وقد عرض الزبيدي لهذا اللفظ بشيء من التفصيل، فقال:" والإردب كقرشب مكيال ضخم لأهل مصر، وفي المصباح الإردب بالكسر كيل معروف بمصر نقله الأزهري، وابن

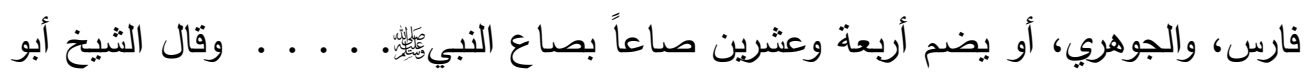

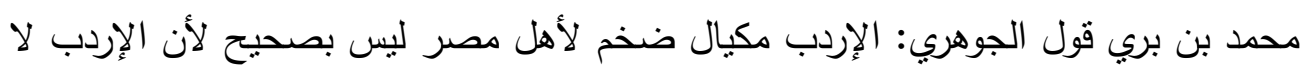

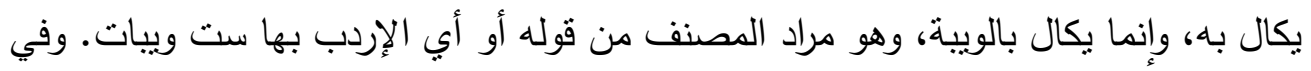
الحديث منعت العراق درهمها وقفيزها، ومنعت مصر إردبها. وقال الأخطل: ( من البسيط) قوم إذا استتبح الأضياف كلبهم قالوا لأمهم بولي على النار والخبز كالعنبر الهندي عندهم القمح سبعون إردباً بدينار قال الأصدعي وغيره "البيت الأول منهما أهجي بيت قالته العرب، ثم إن ظاهر كلامهم أنه عربي، وصرح بعضهم بأنه معرب"( ("ror ). وعليه : فالأردب مكيال مصري يسع أربعة وعشرين صاعاً، أو ست وبيات باته

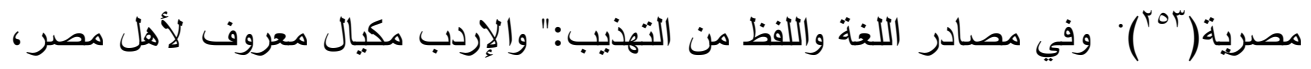

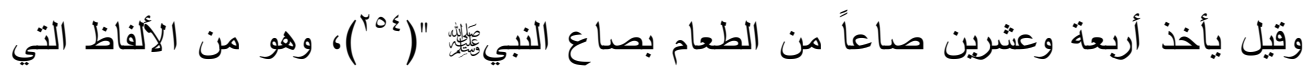

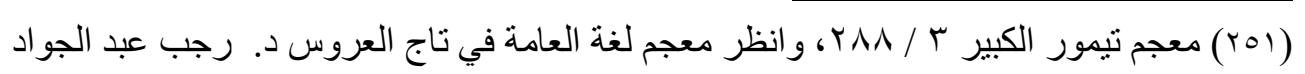

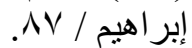

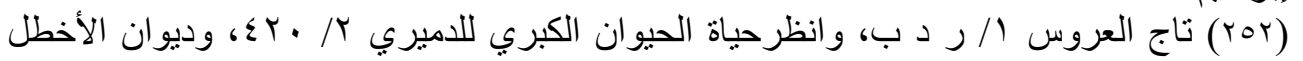

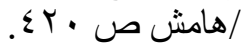
(ror) المعجم الوسيط / / / / أ ردب بتصرف، وانظر القاموس المحيط / / ر د ب، ومحيط المحيط

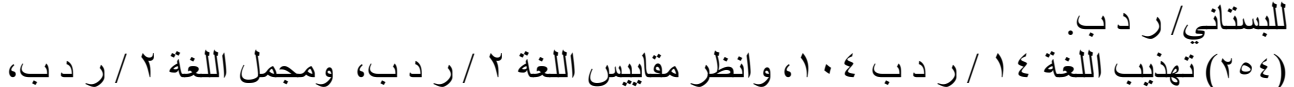

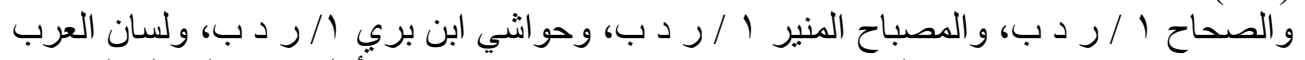

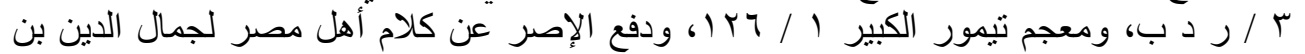

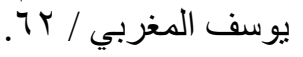


ما نسبه الزبيدي في تاج العروس إلى اللهجة المصرية

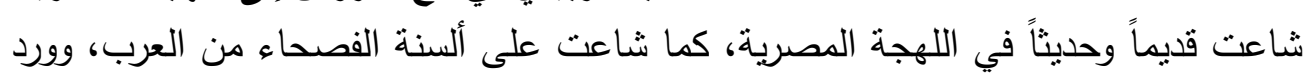
في الحديث النبوي الثريف، ففي الحديث: " منعت العراق درهمها وقفيزها، ومنعت الثام مُدْيها ودينارها، ومنعت مصر

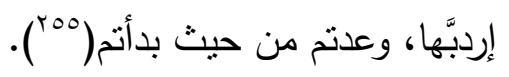

واللفظ من المشترك السامي بين السريانية والعامية المصرية، فاللفظ في السريانية rtba أعجمية خلافاً لما صرح به بعضهه، على حد ما حكى الزبيدي. (الرَّز

الرز أو الأرز ضرب من البر(rov) أو هو نبات حولي من الفصيلة النجيلية يحمل سنابل ذوات غلف صفر تقتر عن حب أبيض صغير يطبخ ويؤكل("101)' وهو معرب ذكره

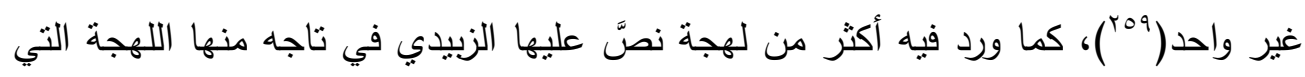

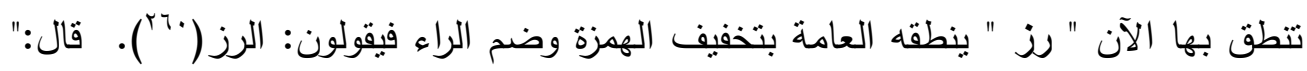
والأرز قال الجوهري:" فيه ست لغات، كأثند، وهي اللغة المشهورة عند الخواص، وأرز مثل بنل

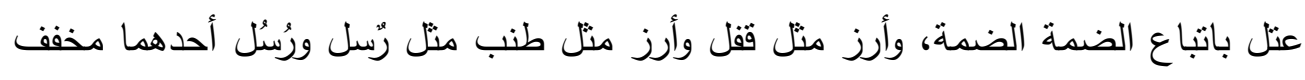
عن الثاني، ورز بإسقاط الهمزة، وهي المشهورة عند العوام، ومحل ذكره في المضعف، ورنز لعبد القيس وسيأتي للمصنف في محله، فهذه الستة التي ذكرها الجوهري، ويقال فيه أيضاً

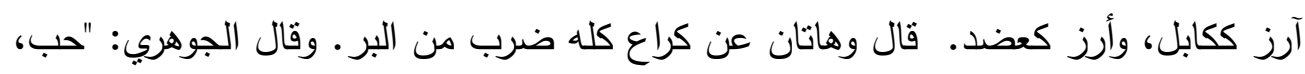
وهو معروف، وهو أنواع مصري، وفارسي وهندي، وأجوده المصري"(ابrان.

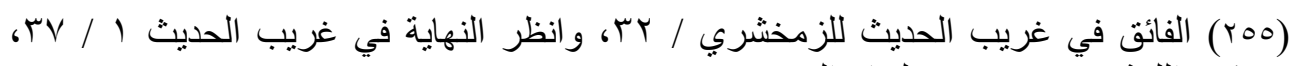

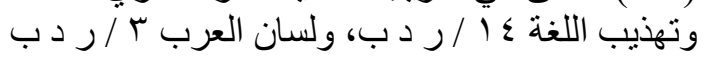

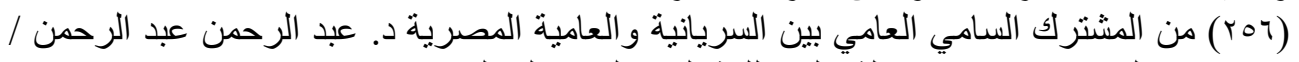

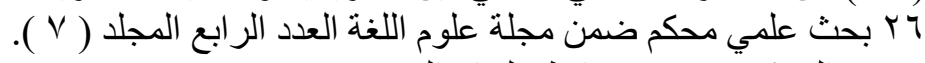

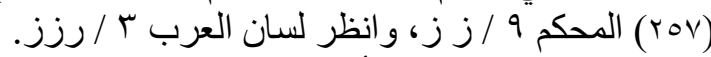

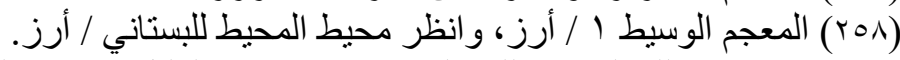

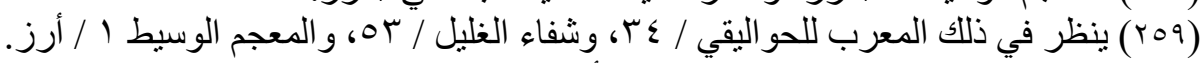

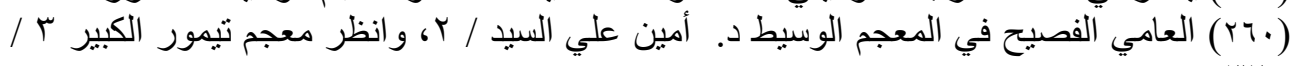

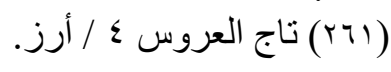




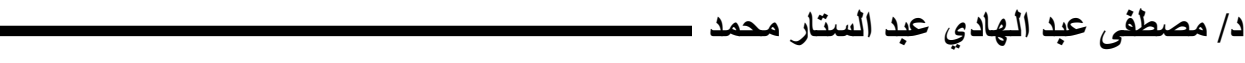
وقد اتفق الزبيدي مع غيره من اللغويين في النصِّ على هذه اللهجات، وانفرد هو

بالإشارة إلى التقريق بين بعض هذه اللهجات على أساس من اختلاف اللاهجين تبعاً لاختلاف النمط الاجتماعي لهم، وهي إثنارة لطيفة تكثف لنا عن بعض أسباب التعدد اللهجي في المجتمع الواحد، والبيئة اللغوية الواحدة، فالأرز كأثندَّ عند الزبيدي لغة شأنسائعة

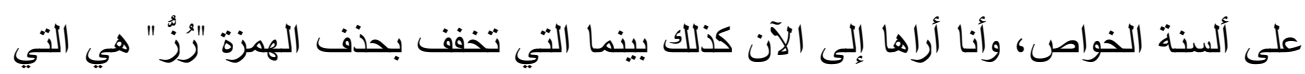
شاعت بسبب كثرة الاستعمال على ألسنة العوام من المصريين، وهي إلى الآن كذلك. وإن أخذت بسبب من الأخرى فكلها لهجات قديمة نصَّ عليها اللغويون وشاعت على على ألسنة

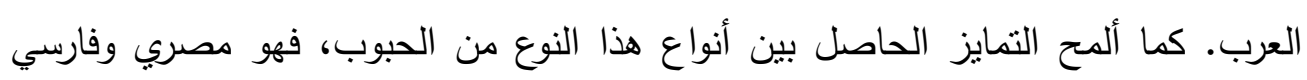
وهندي أجوده المصري على حد قول الزبيدي. يقول الجوهري:" الأرز : حب، وفيه ست لغات

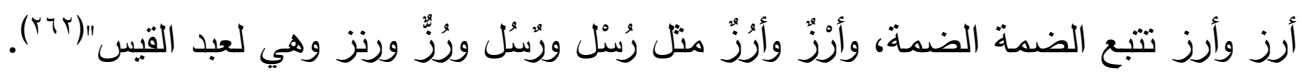

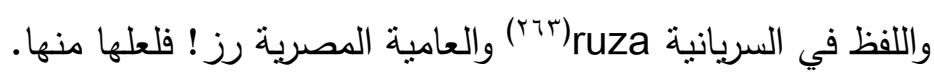

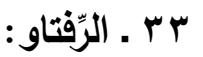

قال الزبيدي:" الرّّفتاو بالكسر مكيال لأهل الصعيد(

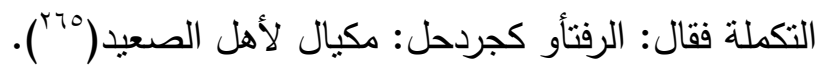
وذكر صاحب معجم لغة العامة في تاج العروس ما نصهه:" وقد أخبرني أحد

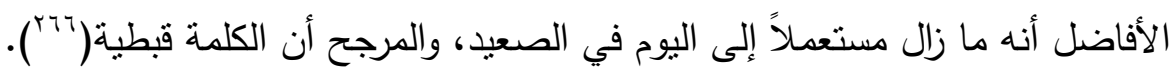

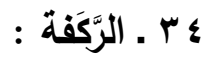

الرَّكَفة بالتحريك لهجة مصرية تكلم بها المصريون زمن الزبيدي، فقد نصَّ عليها الزبيدي فيما استدركه على صاحب القاموس المحيط . قال :" ومما يستدرك عليه : الركفة

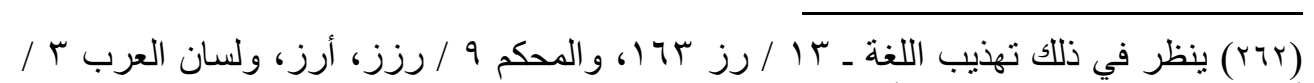

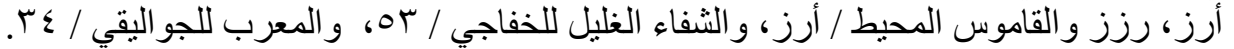

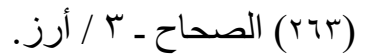

$$
\begin{aligned}
& \text { ( ) }
\end{aligned}
$$

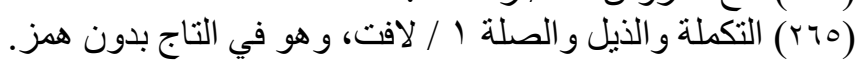

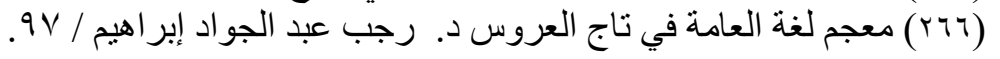


ما نسبه الزبيدي في تاج العروس إلى اللهجة المصرية

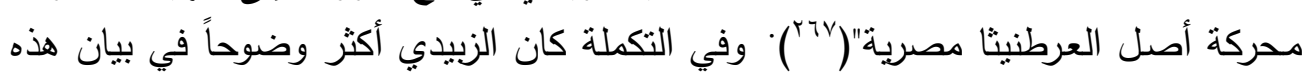

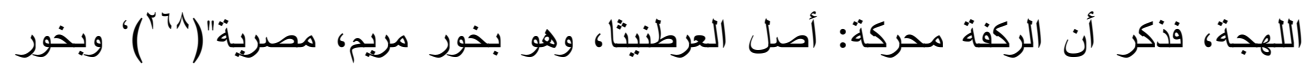

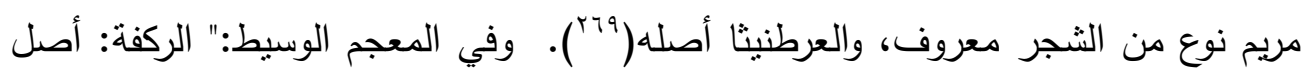

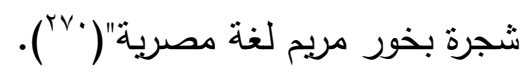

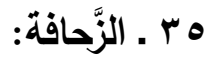

الزَّحافة من ( ز ح ف ) يقال: زحف القوم زحفاً من باب نفع وزحوفاً. . . .

والصبي يزحف على الأرض قبل أن يمشي، وزحف البعير إذا أعيا فجرَّ فِرْسنه. . . . .

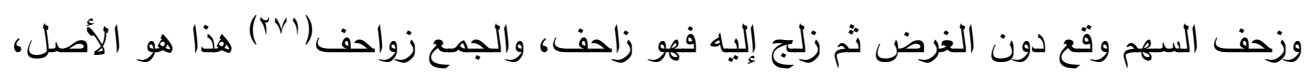

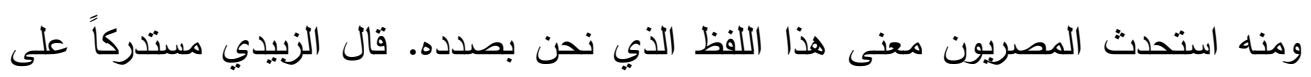

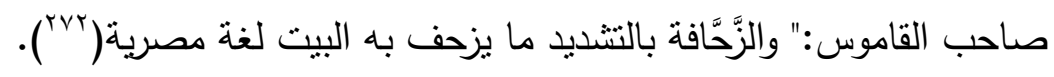

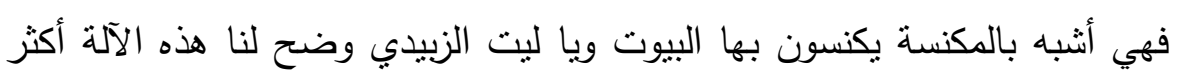

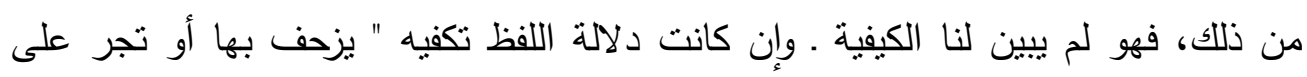
الأرض حال إمساكها باليد" ـ ولا من أي شيء كان المصريون يتخذون الزحافة، ويبدو أن

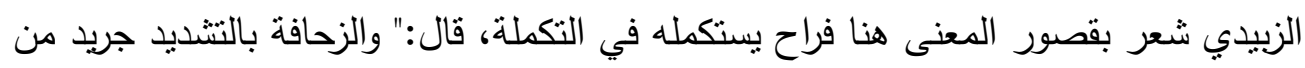

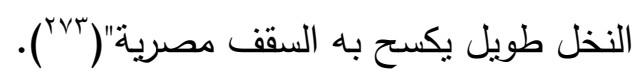
وقد ذكر المغربي أن المصربين يقولون: زحافة لما يجرونها على البيوت لافع الأتربة

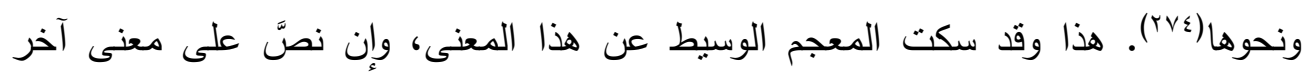

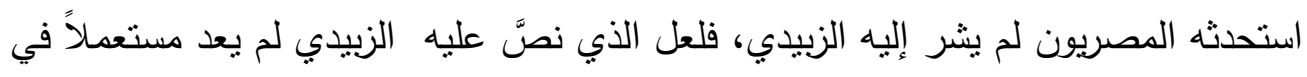

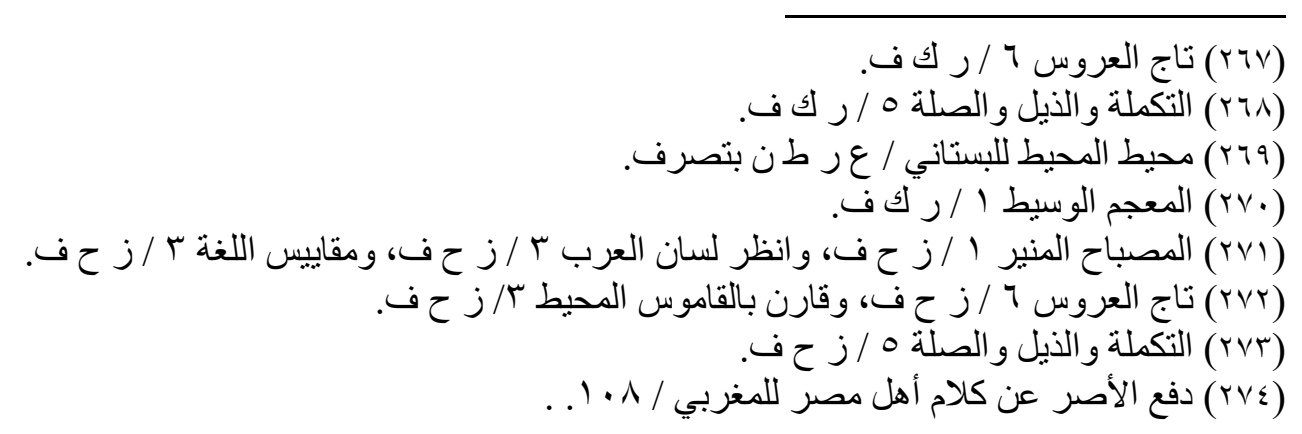

مجلة بحوث كلية الآداب 
د/ مصطقى عبد الهادي عبد الستار محمد

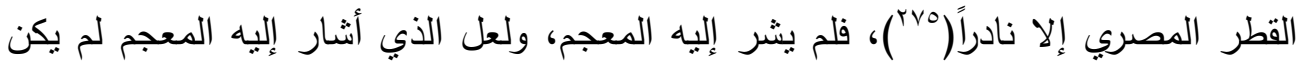
بعد في عصر الزبيدي محدثاً، ففي الوسيط:" زحف الثيء: جره جراً ضعيفاً، والأرض: سواهنا الهاه

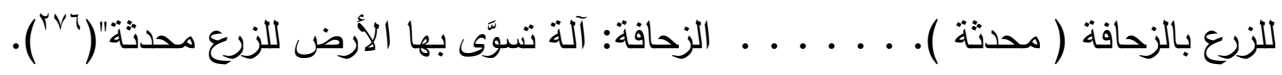
وفي معجم تيمور المعنيان على السواء مما يدل على القصور في المعجم الوسيط، فالمعنى الذي نحن بصدده ذكر المعجم فيه أن الزحيف تتظيف الحائط وأعالي السقف من

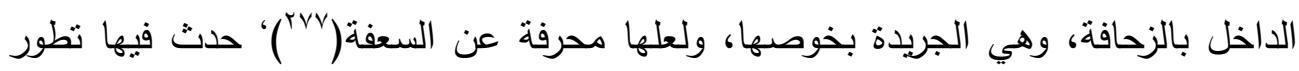
صوتي والمعنى يحتمله، فالسعف أغصان النخلة، وأكثر ما يقال إذا يبست، والسعف: ورق ورن

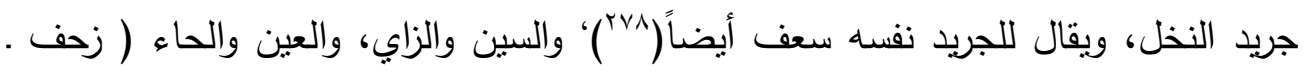
سعف ) بينها من القرابة الصوتية والمخرجية ما يسوغ وقوع الإبدال فيها، فهما مما بين طرفي اللسان وفويق الثتايا، فكلاهما رخوان مستفلان منفتحان، ولا يفترقان إلا في صفتي الهمس

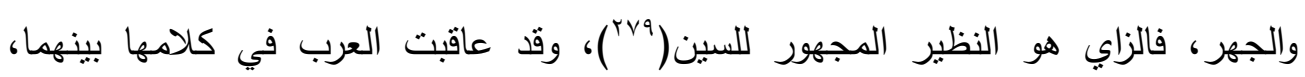

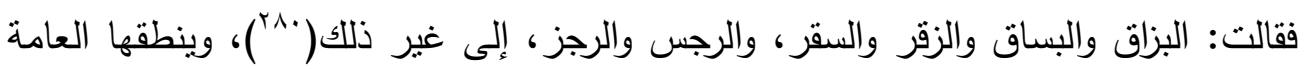
الآن زعافة ينظف بها الحوائط والأسقف، فيبدلون الحاء عينا.

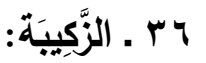

الزَّكْب: المله، وزكب إناءه يزكبه زكباً وزكوباً ملأه(1)

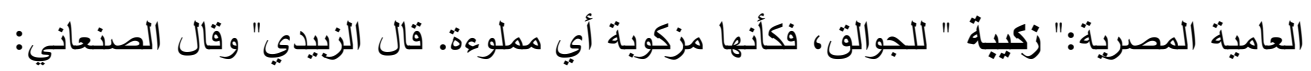

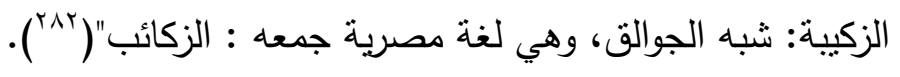

(TVO) هذا اللفظ إلى عهد قريب جداً كان بستعمل في قريتي من مركز أثمون، فيطلقون الزحافة على المكنسة ( المقتشة

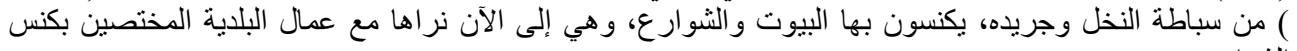

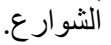

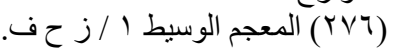

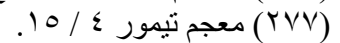

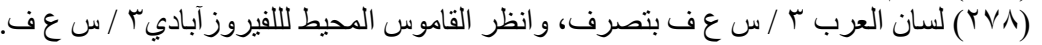

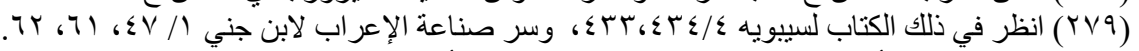

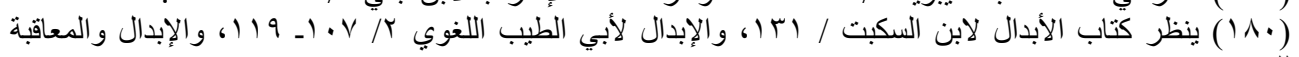

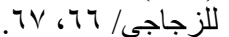

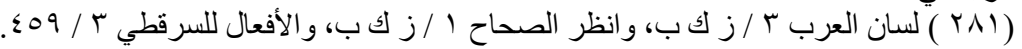

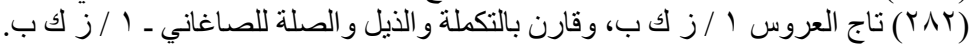




\section{ما نسبه الزبيدي في تاج العروس إلى اللهجة المصرية}

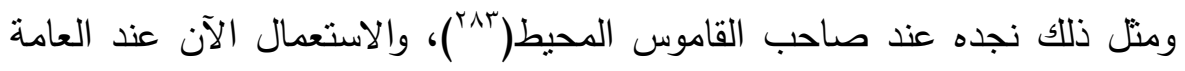

يؤكد قدم هذه اللفظة في تاريخ العامية المصرية، فالمعجم الوسيط نصنَ على أن الزكيبة:

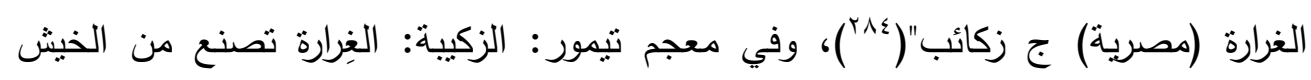
استعملها ابن إياس. . . . . . والعامة نستعمل الغرارة مع فرق بينها وبين الزكيبة. في الأحراز

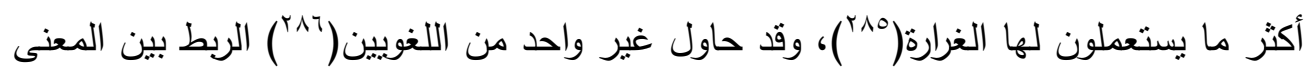
العامي للفظ، وما تأصل سابقاً في صدر المسألة من إمكان رده إلى أصل مادته العربي

الفصيح.

- v

أوقفنا الزبيدي على المعنى العامي لهذا اللفظ عند المصريين في ناجه وكذا في

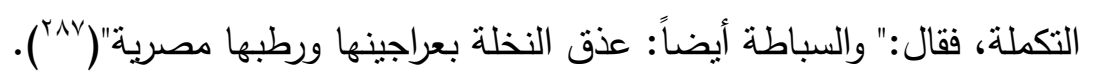
وتتفق المعاجم القديمة على أن السباطة تعني في لغة العرب: الكناسة تطرح بأفنية البيوت(1^)، وعند ابن منظور :" السُّاطة ما سقط من الثعر إذا سرح والسُّباطة: الكناسة. . . . . . . السُّاطة والكناسة: الموضع الذي يرمى فيه التراب والأوساخ وما يكنس من المنازل. . .

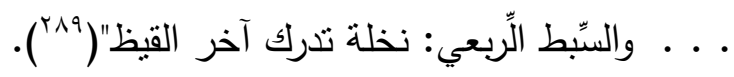

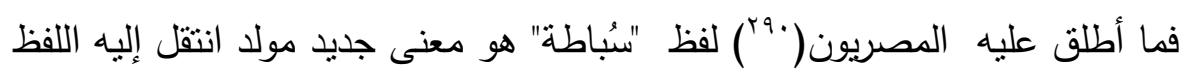
في لهجتهم، ويحتمل إطلاق المصريين لفظ السُباطة على عراجين الكباسة من النخلة برجع إلى المعنى الأخير عند ابن منظور :" السبّط الرِّبعي. . . . . . . نوع من النخل أو إلى على

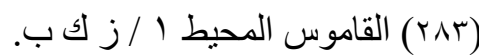

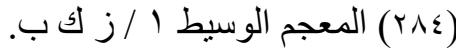

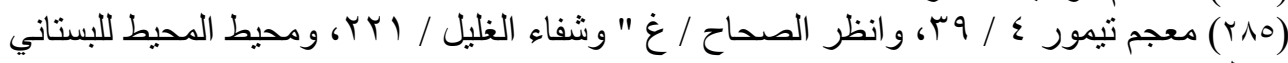

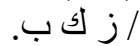

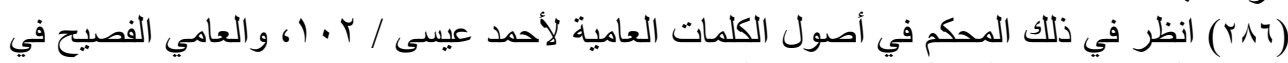

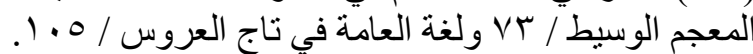

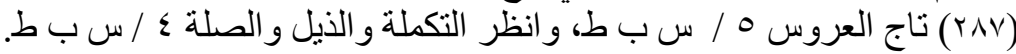

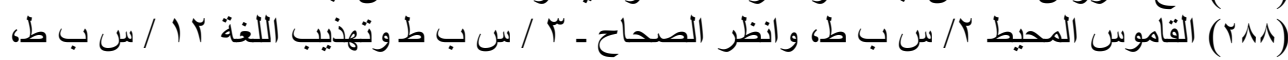

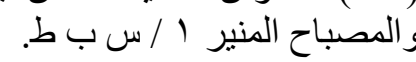

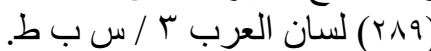

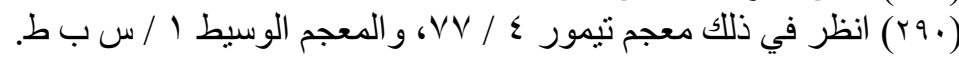


د/ مصطفى عبد الهادي عبد الستار محمد

الأول: السباطة بمعنى الكناسة، لأنهم كانوا يكنسون بها على على ما هو معهود قديماً وإلى وقتتا الحالي من اتخاذ عراجين النخل لهذه الغاية، ثم تطور اللفظ من إطلاقهم السُّاطة على هلى هلى الكناسة إلى الآلة التي يكنسون بها، والعلاقة القربية بين الفعل والأداة " الآلة " هي التي سوَّغت منل هذا الانتقال الدلالي. هذا وقد أرجع الدكتور أحمد عيسى لفظ السباطة إلى اللغة البونانية، دخلت المصرية القديمة بمعنى طلع كافور، وشاع استعمالها في مصر السفلى، وأطلقت على عزق النخلة،

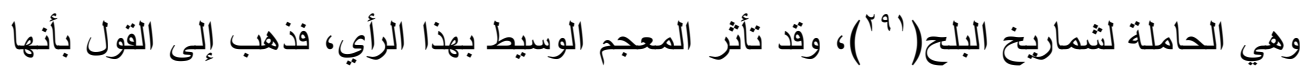
مصرية قديمة عربيتها: الكباسة(rوب)، وهو رأي غربب في في بابه، بعد بيان أرومتها العربية، والانتقال الدلالي أمر تسوغه القوانين اللغوية، أو ليس غريباً إذن ـ واللغة بنت بيئتها ـ أن تعزى إلى اليونانية وليس لبيئة اليونان ولا لأرضها معرفة بالنخل ولا بسباطه، فالنخلة عربية

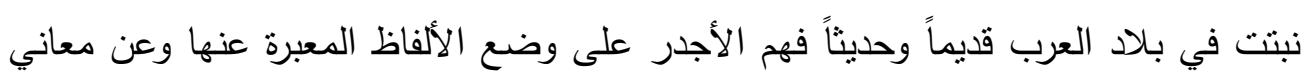
أجزائها.

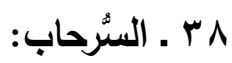

قال الزبيدي:" ومما يستدرك عليه السُرخاب بالضم، أهمله الجماعة، وذكره أحمد بن عبدالله التيفاشي في كتاب الأحجار، وقال: إنه طائر في حجم الأوز أحمر الريش، ويوجد في بلاد الصين والفرس، وأهل مصر يسمونه البشمور، ويعلقون ريشه في المواكب للزينة. . . $\left.{ }^{\text {rar }}\right)^{\prime \prime}$.

وهو ما نص عليه أيضا في التكملة(؟وب) بلا زيادة، ويضاف إلى ما ذكره الثيخ في وصف هذا الطائر أنه يكثر في مصر ويعشش في جزر مياه منقطعة في زمن الأمطار والسيول، فإذا نضب الماء وسعت أعشاشه فحفر تحتها قدر ذراعين فيوجد هناك حجر واحد

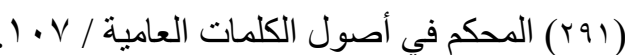

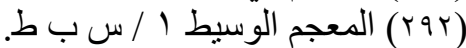

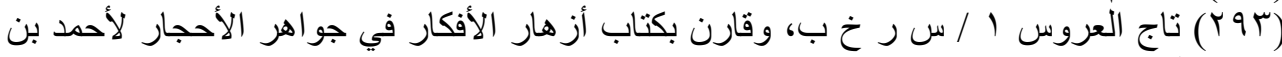

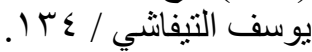

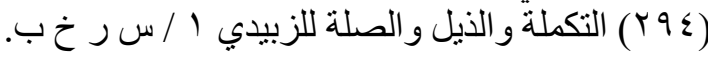

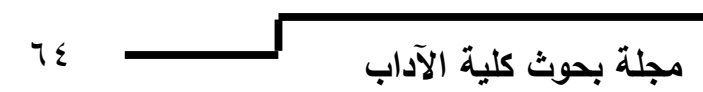


ما نسبه الزبيدي في تاج العروس إلى اللهجة المصرية

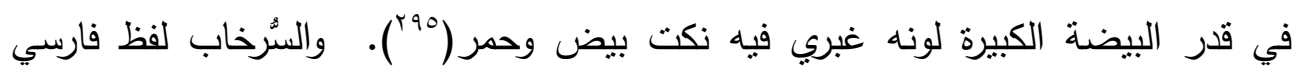

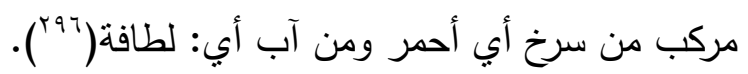

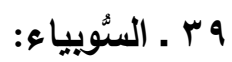

استدرك الزبيدي على الفيروزآبادي لفظ السوبيا، فقال:" ومما أهمله المؤلف ذكر

السوبية، فقد ذكرها في النهاية في حديث ابن عمر، وابن الكتبي" فيما لا يسع الطبيب

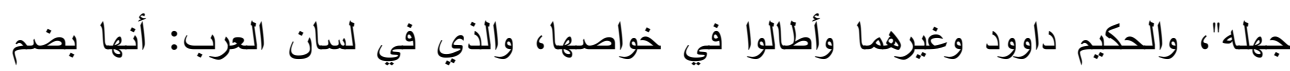

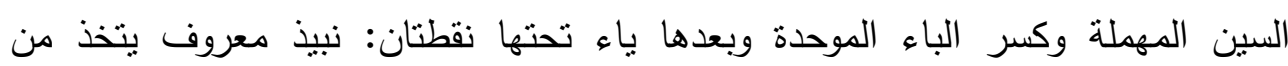
الحنطة، وكثيرا ما يشربه أهل مصر. انتهي، أي في أعيادهم. قال شيخنا: وقد يستعطونه

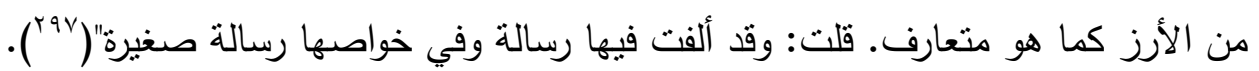
والقول فيها نصا لابن الأثير (9^بـ) في النهاية فيما نقله عنه ابن منظور في اللسان،

وكذا

الزبيدي أيضا في التكملة. قال:" وسوبية: نبيذ من حنطة أو أرز يشربه أهل مصر . عن ابن

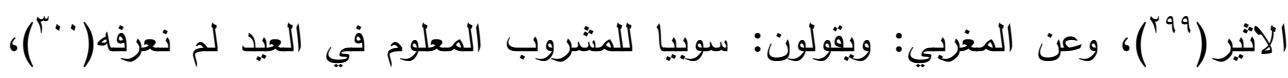
وتتفق مع من نص على هذا اللفظ بمفهومه السابق، وهو إلى الآن في عاميتنا، وفي المعجم الوسيط زيادة في الوصف ففيه: السوبية: شراب يتخذ من الرز ويخمر قليلا ويسكر، وكثيرا

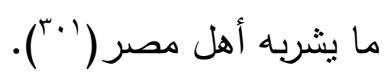

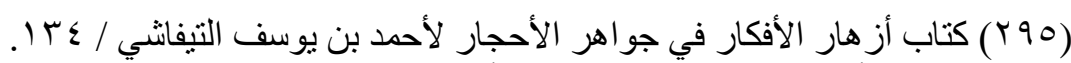

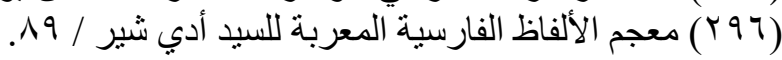

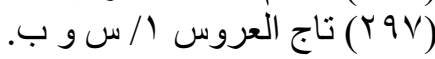

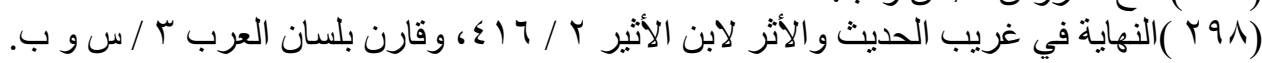

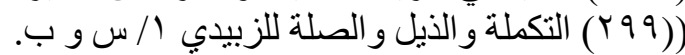

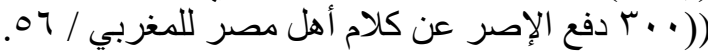

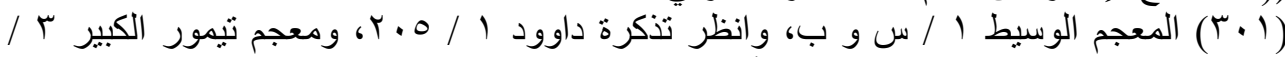

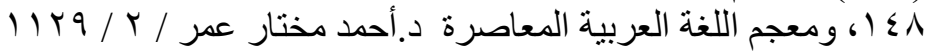


د/ مصطفى عبد الهادي عبد الستار محمد

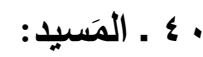

المسيد لهجة وردت في لفظ" المسجد" على ألسنة بعض المصربين، ذكر ذلك الزبيدي مستدركاً على صاحب القاموس قال:"ومما يستدرك عليه . . . . . . والمسيد لغة في

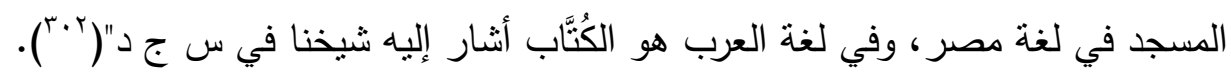
ولم تكن هذه اللهجة في لسان المصريين فحسب بل كانت شائعة في لسان أهل صقلية، ففي باب ما تنكره الخاصة على العامة وليس بمنكر ذكر ابن مكي الصقلي قولهم

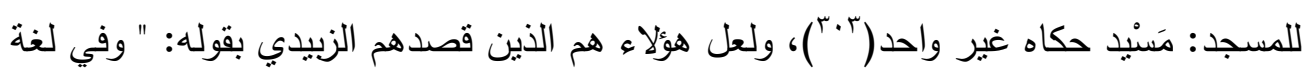

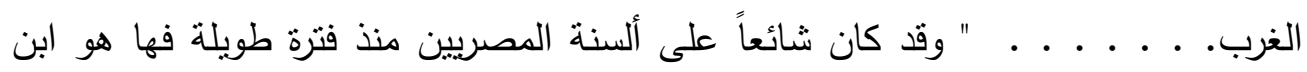
سودون من أدباء القرن التاسع الهجري تجري على لسانه وقلمه في خطاب أرسله شاب من الصعيد إلى أبويه:" ولكني من الرجفة وجعتتي عيني الذي تبقى من ناحية المسيد وقت أخرج

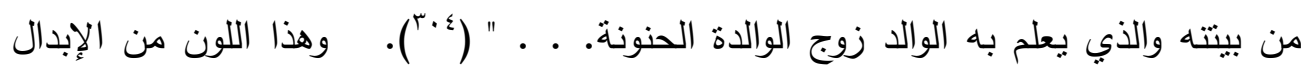
اللهجي معروف في اللهجات العربية القديمة. فقد قال أبو حاتم قلت لأم الهيثم: هل تبدل العرب الجيم ياء في شيء من الكلام؟ فقالت: نعم، ثم أنشدنتي: (من الطويل).

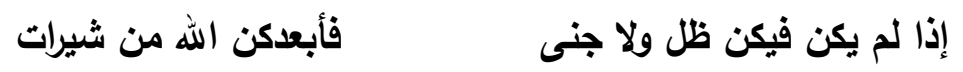

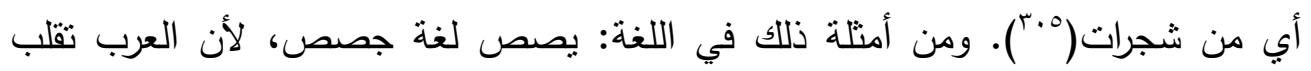

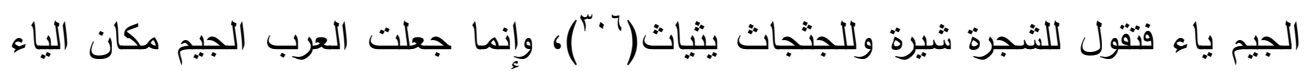

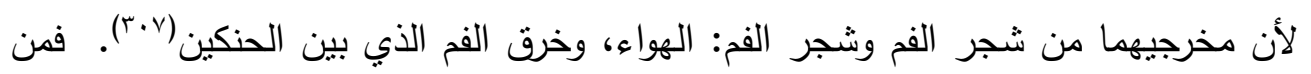

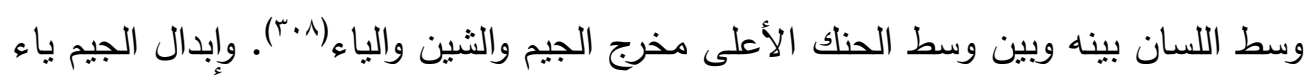

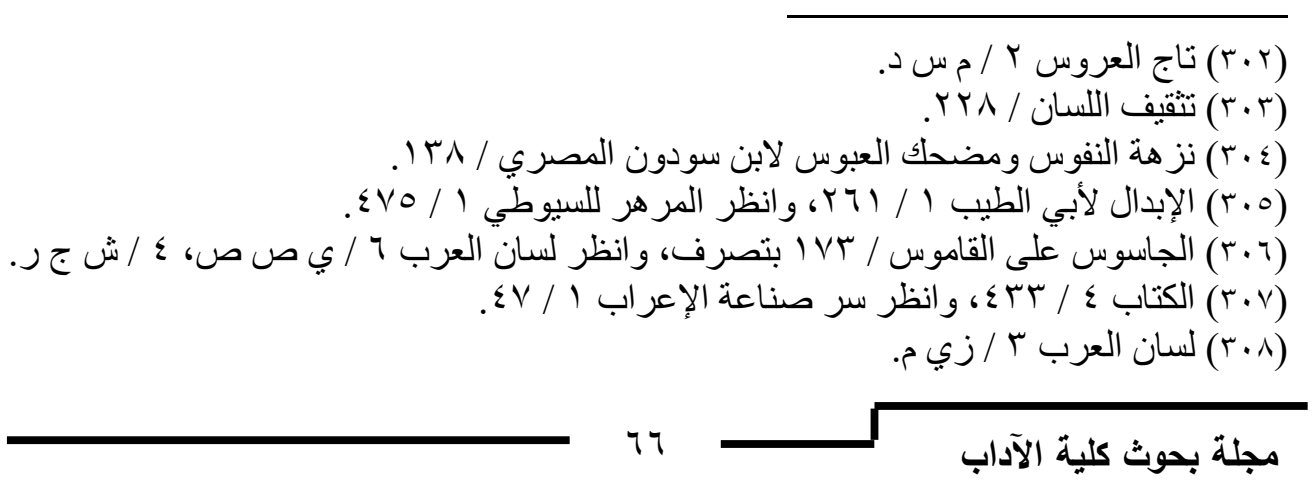


ما نسبه الزبيدي في تاج العروس إلى اللهجة المصرية

فيما سبق لغة في تميم معروفة. قال شمر:" الذي سمعت بعير أزجم بالزاي والجيم، قال:

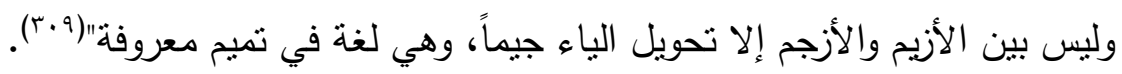

إ: ـ ـ الشادوف:

الثادوف أداة من أدوات الري عند المصربين، وقد استدرك الزبيدي هذا اللفظ بمعناه العامي على صاحب القاموس المحيط، فقال:" ومما يستدرك عليه : .. . . . . والثنادوف ما

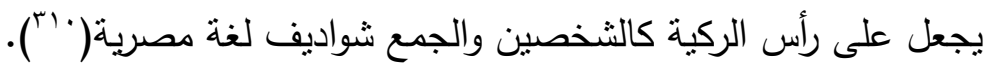

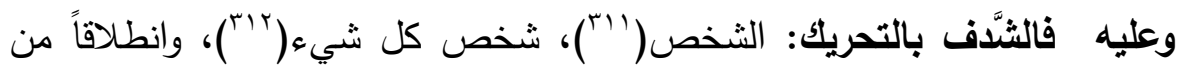

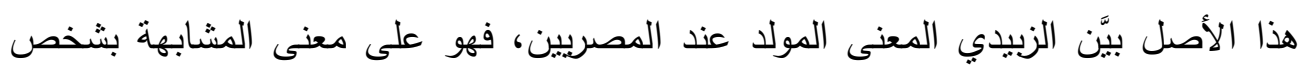
الإنسان وغيره، وقد أوضح هذا الأمر في التكملة، فنصنَ على أن الثادوف ما ينصب يشبه الثخص في الزرع ليفزع به الطير وما يجعل على رأس الركية يشبه الثخصين تركب عليه

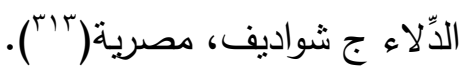
وفي بعض المعاجم واللفظ من المعجم الوسيط: " الثادوف أداة لري الأرض، وهي

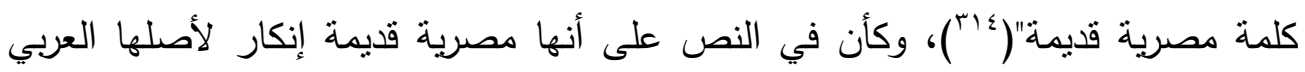

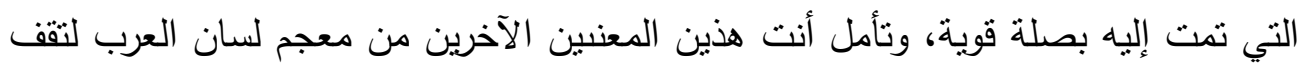
على عروبة هذا اللفظ، فالثدف: التواء رأس البعير، والثدف في الخيل والإبل: إمالة الرأس

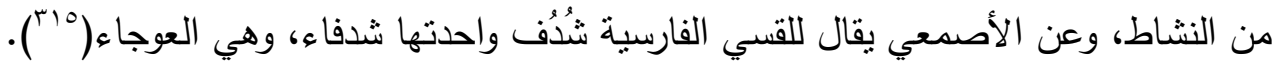

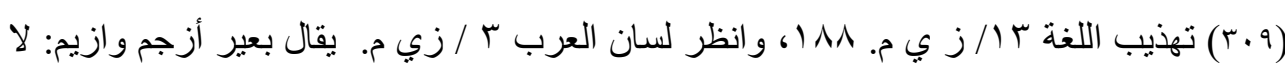

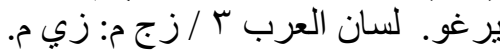

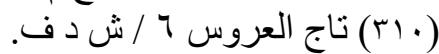

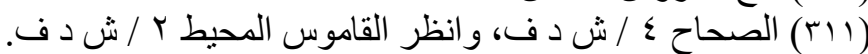

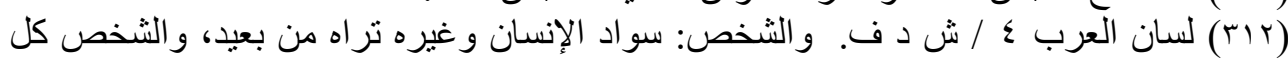

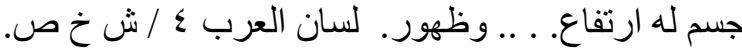

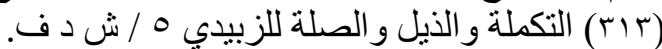

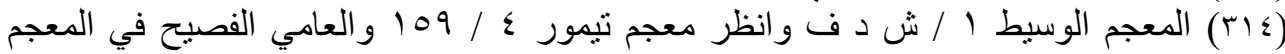

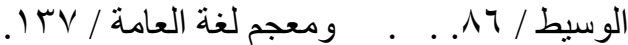

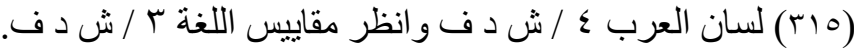




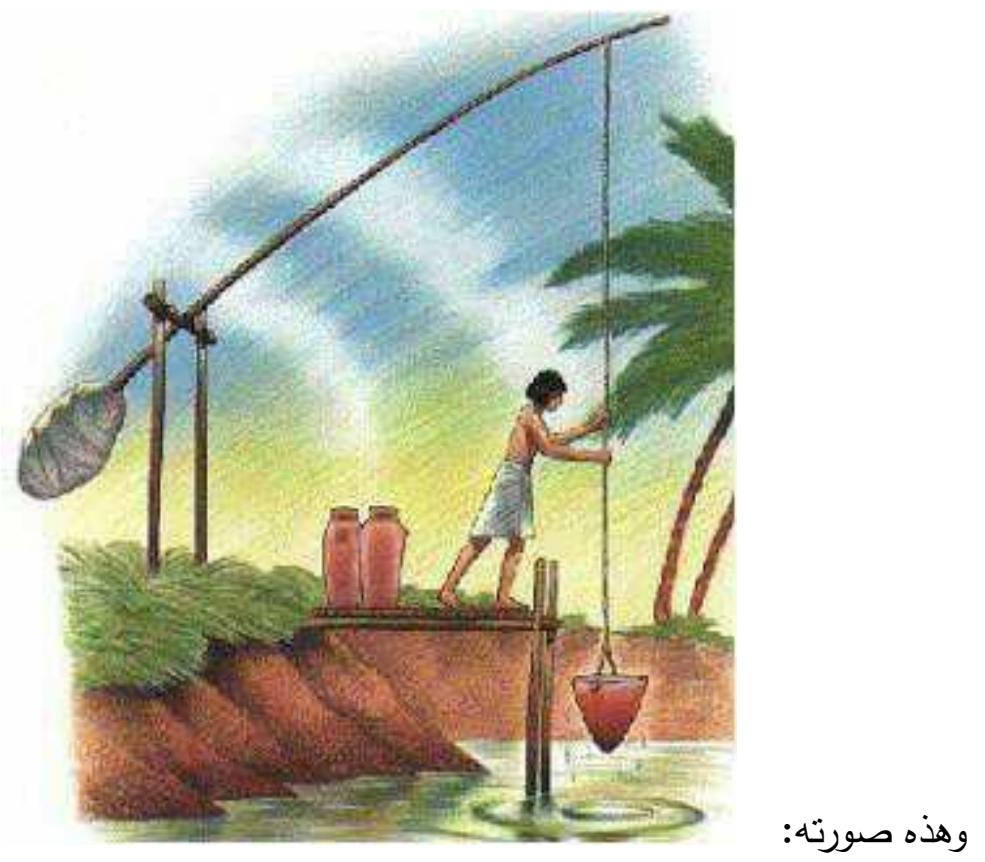

فكأنه شخص مائل حتى يتمكنوا من مله الدلاء، إذ كانوا ينصبونه على شفير الترع والمصارف وفروع النيل لسقي الأرض، أو لسقي ما يتعذر سقيه من الأراضي بوسائل أخرى من دولاب ونحوه لارتفاع الأرض عن مصدر الماء. وهو من المشترك بين العربية والسريانية

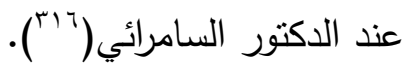

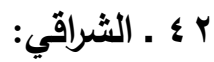

استدرك الزبيدي على صاحب القاموس المحيط لفظ الشراقي في اللهجة المصرية، فقال:" ومما بيتدرك عليه .. . . . . . . . . وشرقت الأرض الأرض تشريقاً: أجدبت، وذلك

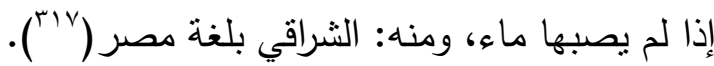
ويؤيد ما ذهب إليه الزبيدي استعمال العامة من المصريين في الريف إلى وقتتا هذا لهذا اللفظ بمدلوله عند الزبيدي، وفي شفاء الغليل ما يكثف لنا عن طبيعة هذه اللهجة

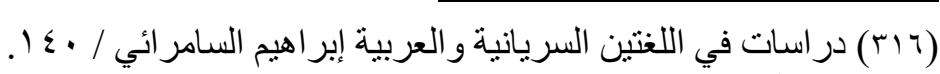

$$
\begin{aligned}
& \text { (T/V) }
\end{aligned}
$$

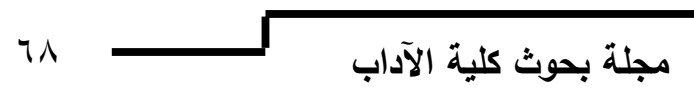


ما نسبه الزبيدي في تاج العروس إلى اللهجة المصرية

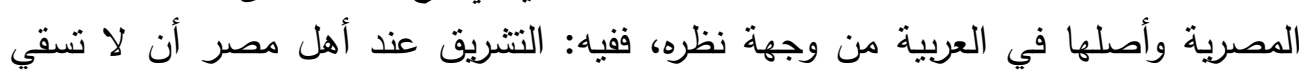

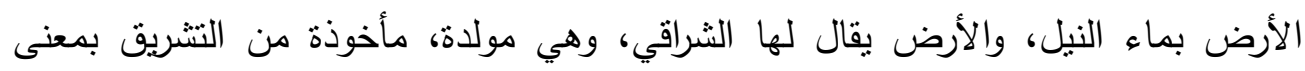

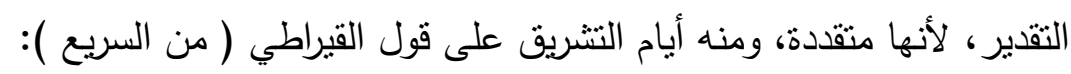

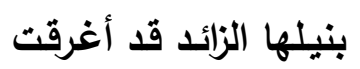

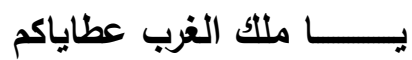

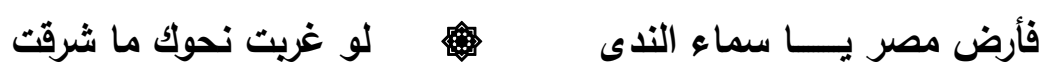

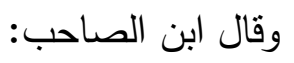

\section{وافي النيل مصر

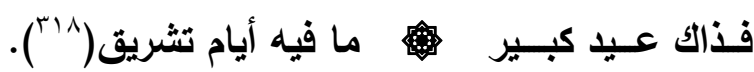

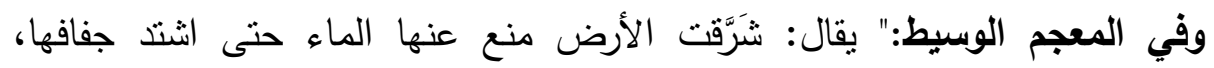

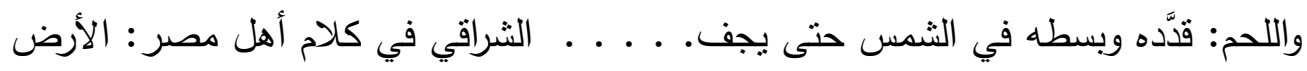

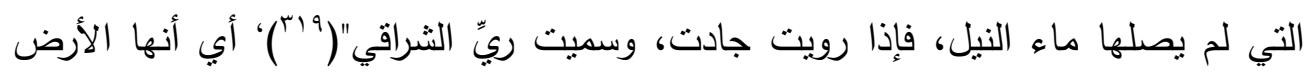

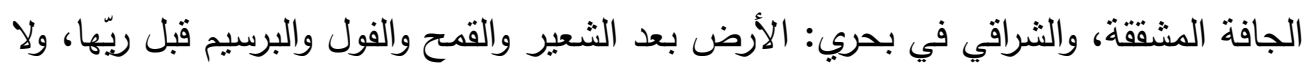

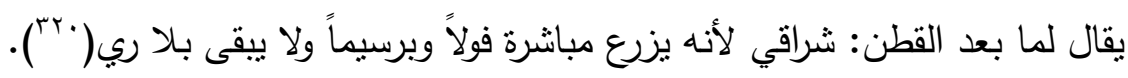

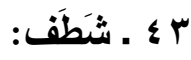

نقول في دراجتنا:شطف الثوب والكوب والإناء، وشطف وجهه أو يديه أو رجليه:

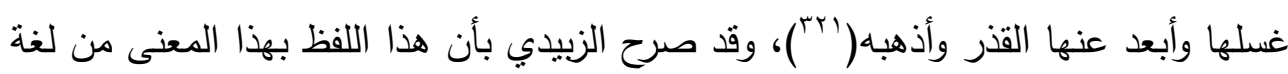

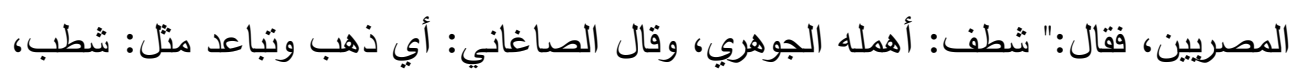

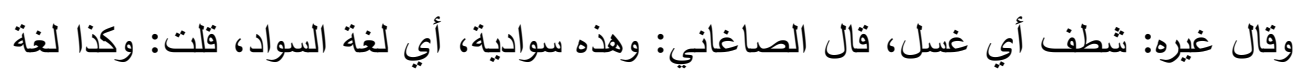


د/ مصطفى عبد الهادي عبد الستار محمد

مصر"( دrrr)، كما استدرك الزبيدي على صاحب القاموس أيضاً: التشطيف كالثطف بمعنى

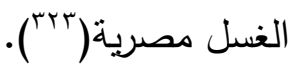

والمروي عن الأصمعي: شطف وشطب: إذا ذهب وتباعد، وفي النوادر : رمية شاطفة

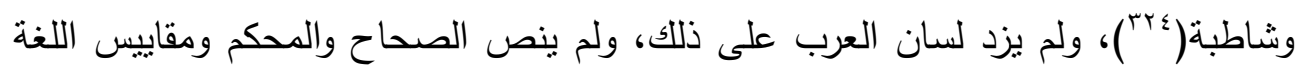

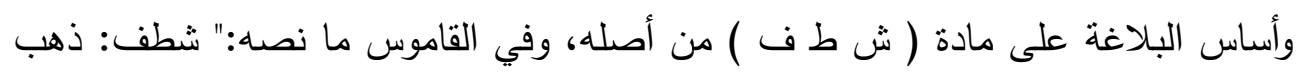

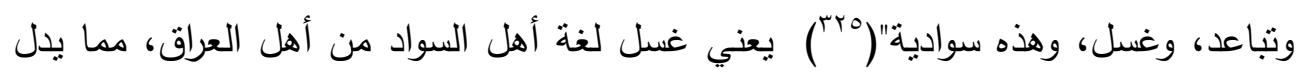

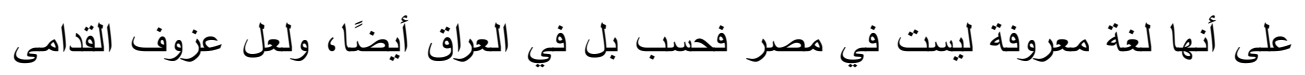
عن النص عليها في مؤلفاتهم يرجع إلى أنها من كلام أهل السواد. يقول المغربي:"وأما

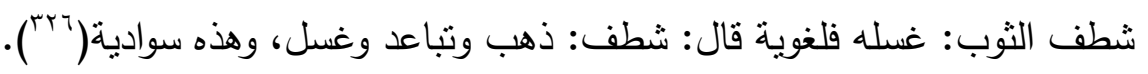
هذا ولم ينص الصاغاني والفيروزآبادي ولا الزبيدي من بعدهما على أن" شطف" بهذا

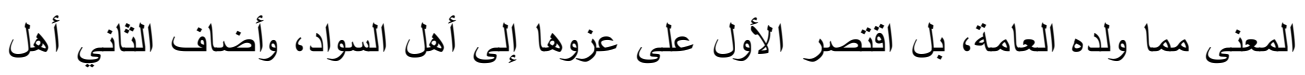
مصر ، وذلك خلافًا لما نص عليه المعجم الوسيط، فقيه:" شطف عن الثيء الثيء شطفاً: عدل الثل وتباعد، والثوب: غسله مولدة"(rrV).

ولا أتفق مع ما نص عليه الوسيط، فالقول قول الفيروزآبادي والزبيدي في هذا الصدد، إذ اللفظ قديم قدم العرب في سواد العراق وجزيرته، فاللفظ من الموروث اللغوي، أو

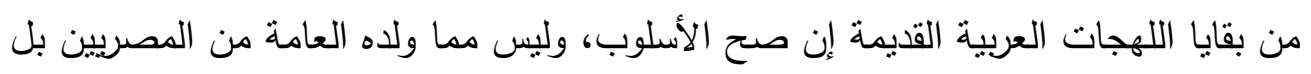

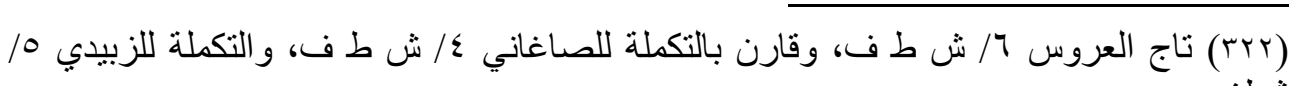
شطف ( )

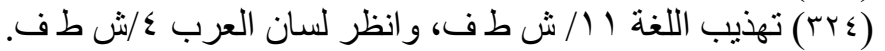

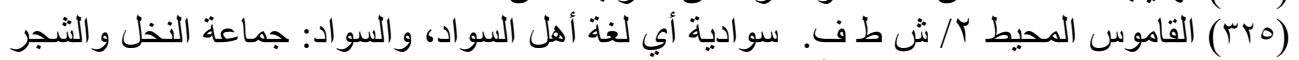

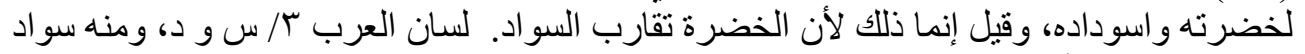

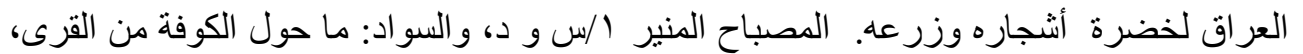

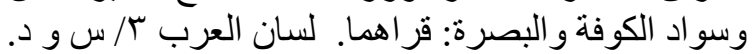

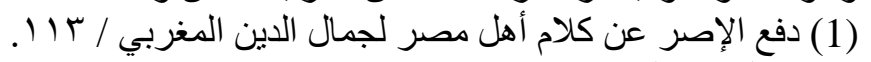

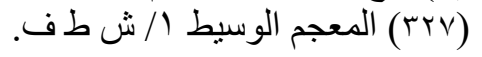

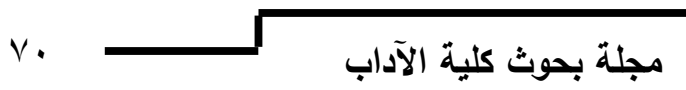


ما نسبه الزبيدي في تاج العروس إلى اللهجة المصرية

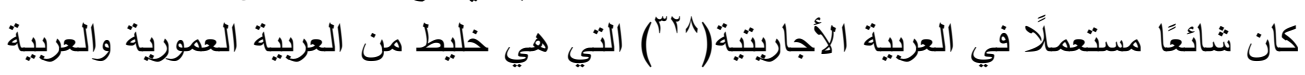

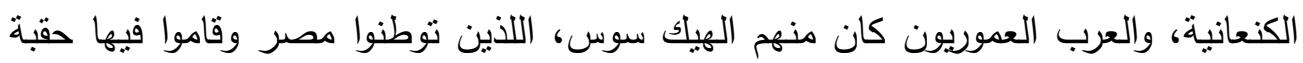

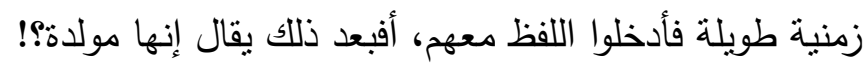

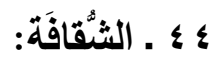

نقول في دراجاتتا الثققة ما تكسَّر من الخزف أو ما بقي بعد كسره(جوَ)، وقد استدرك الزبيدي على صاحب القاموس هذا اللفظ،، فنص على اللهجة المصرية فيه.

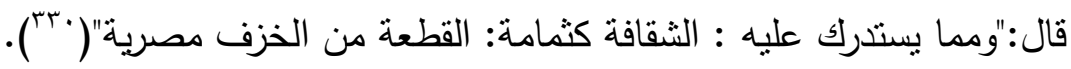

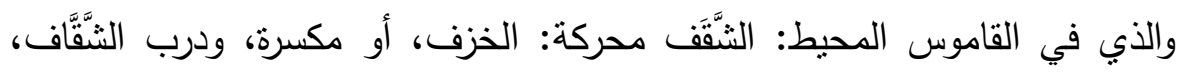

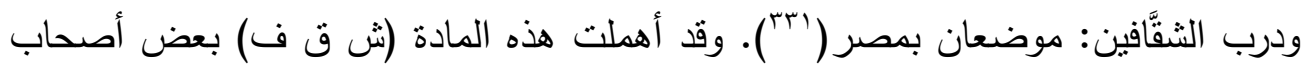

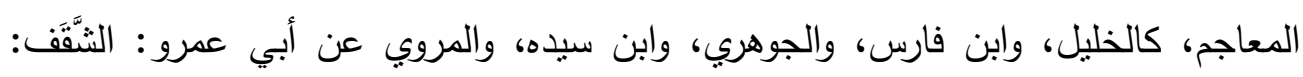

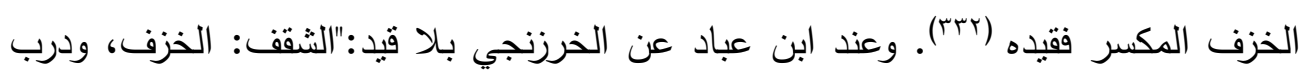

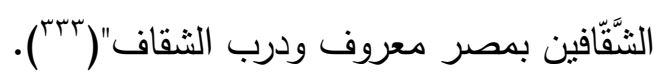

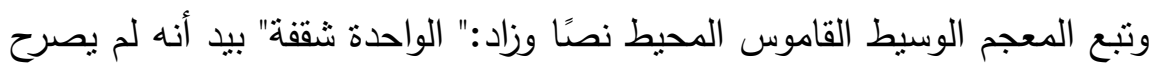

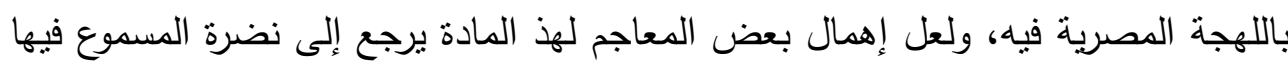

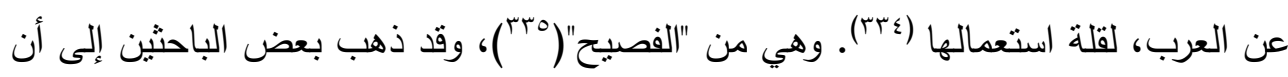

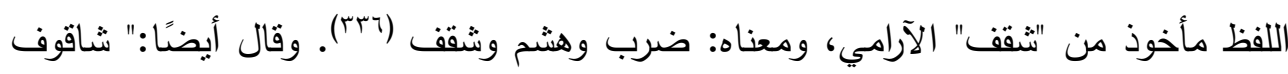

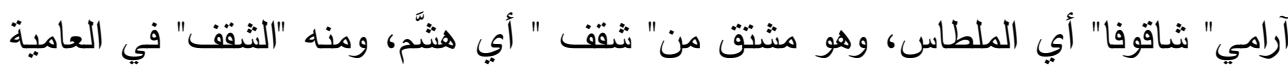

ملامح في فقه اللهجات العربيات من الأكادية والكنعانية وحتى السبئية د. بهجت القبيسي/ YYA)

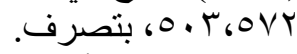

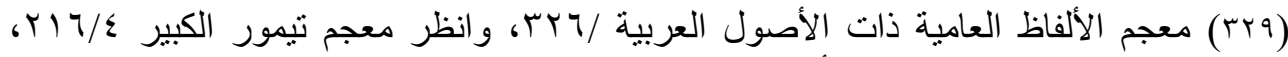

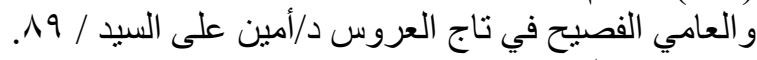

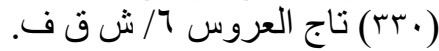

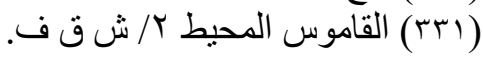

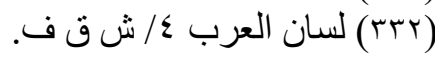

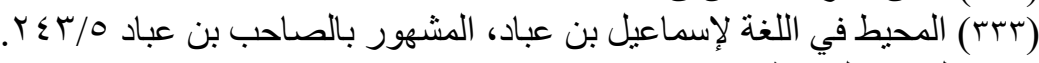

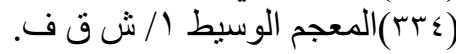
(r) ( 


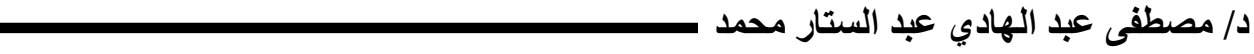

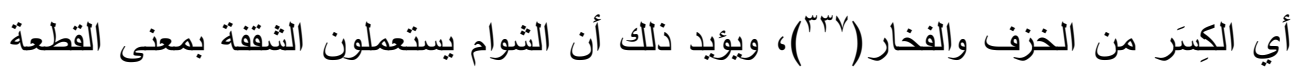

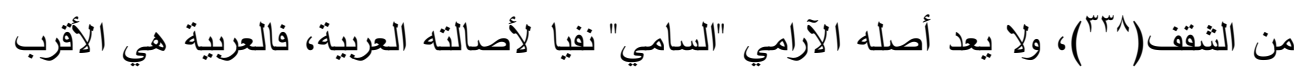
إلى الجذورالسامية من أخواتها الساميات.

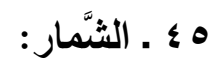

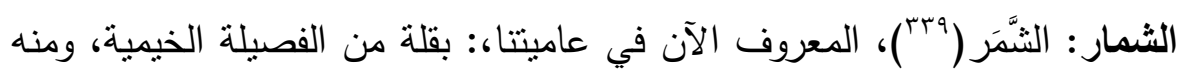

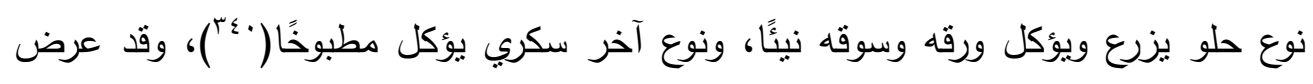
الزبيدي للصيغة الأولى "الثمار" ولعلها هي التي كانت شائعة مستعطلة في عصره، بل ونل كانت

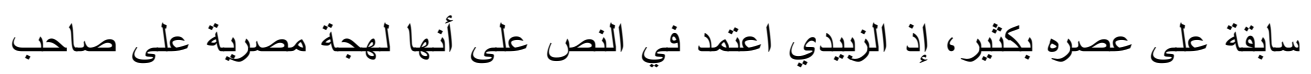

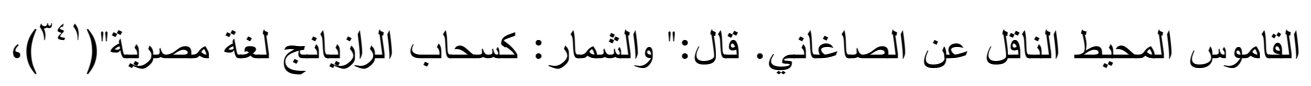

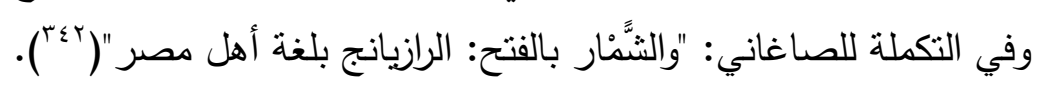

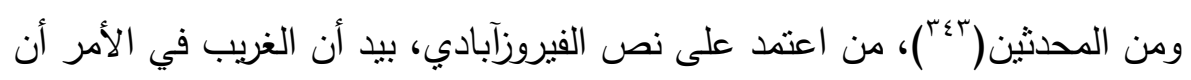

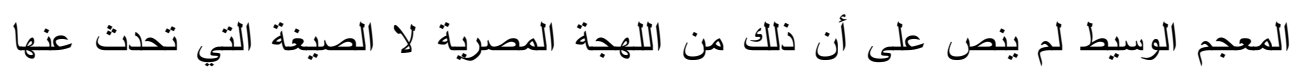

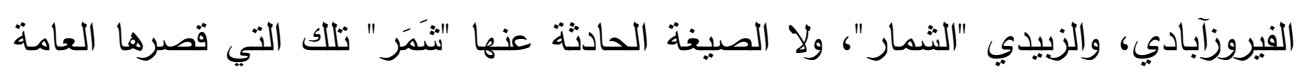
الآن وعزاها إليهم الزبيدي في موضع آخر من تاجه، فقال:"السنََّْت: الرازيانج، وهو الثمر

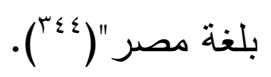

هذا وبالرجوع إلى لفظ "الرازيانج" الذي وقع تفسيرًا في كلامهم السابق للفظ الثمار ، فران ومن ثََّّ الثمر، قالوا فيه: هو ضربان: بستاني، وبري، والبستاني أرطب، والبري أيبس، وقد

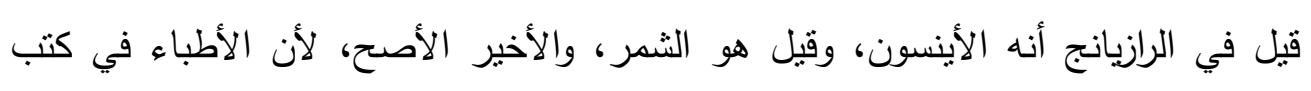

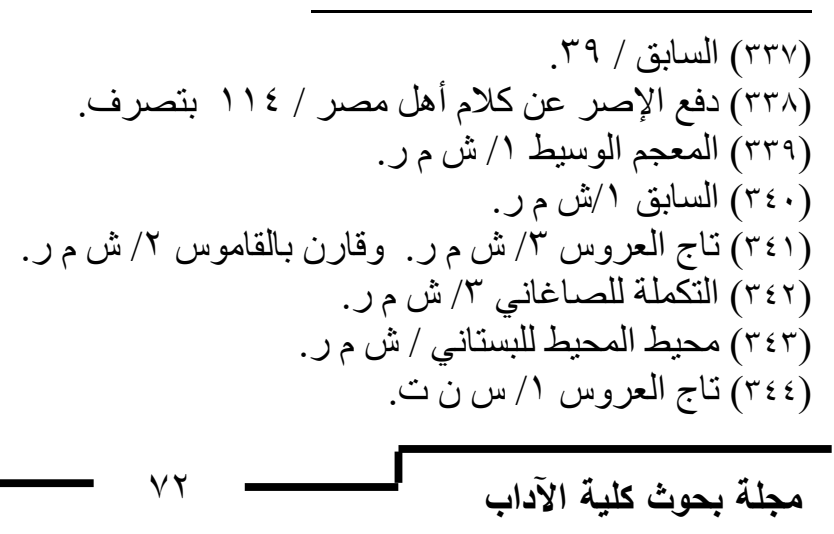


ما نسبه الزبيدي في تاج العروس إلى اللهجة المصرية

المفردات يذكرون الأينسون في حرف الهزة ثم يذكرون الرازيانج في حرف الراء، ويذكرون

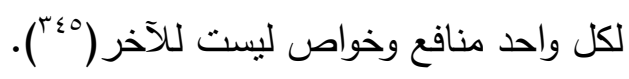

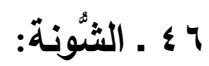

في العامية المصرية نطلق الثُونة على مخزن الغلال، وقد عرض الزبيدي لهذا

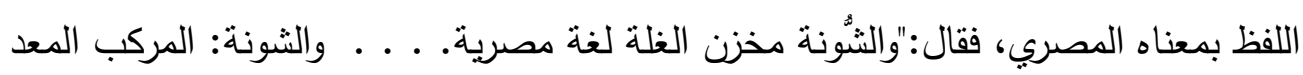

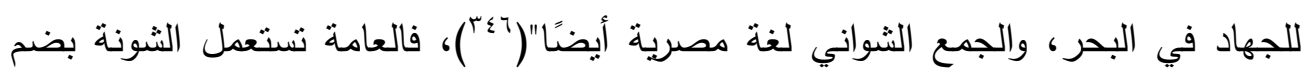

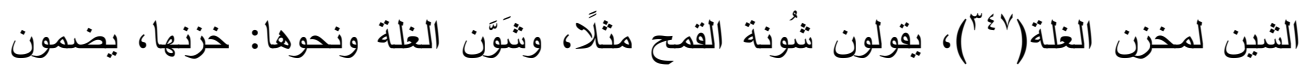

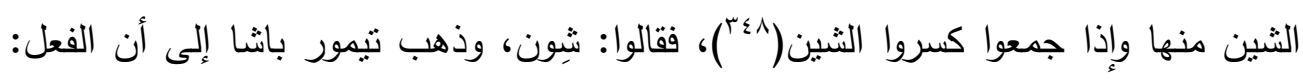
شَوَّن اشتقوه من الثونة، وهي تركية: جون، وفي الألمانية (scheune) شويني بمعني مخزن، فلعل التركية منها ( وفي القاموس المحيط: الثونة: المرأة الحمقاء، ومخزن الغلة مصرية، والمركب المعد للجهاد في البحر( (*))، الأخيرة لهجة مصرية أيضًا عن صاحب التاج، وقد اعتمد المعجم الوسيط على التاج في النص على هذه اللهجة، فقال:" الشونة: مخزن الغلة (مصرية) ج جانه شون، وسفينة حربية قديمة ج شوان (مصرية عن التاج)"(("))، وفي محيط المحيط: والعامة

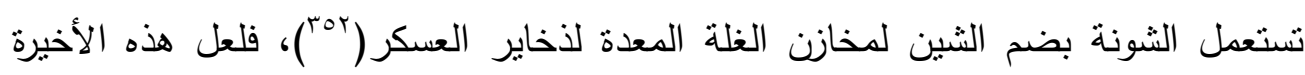

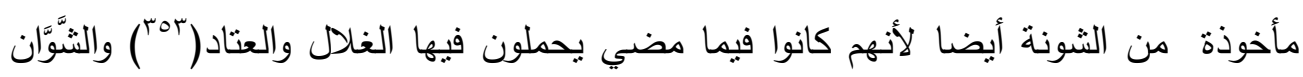

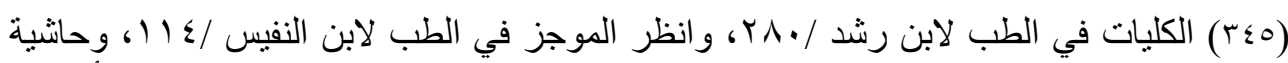
الصفحة نفسها وتذكرة داود" تذكرة اولي الالباب والجامع للعجب العزب الطجاب" لداود بن عمر الأنطاكي

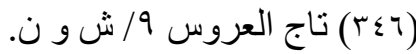

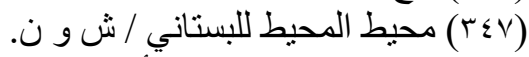

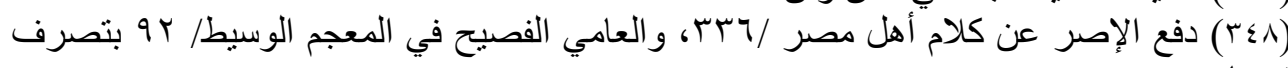

Tr/

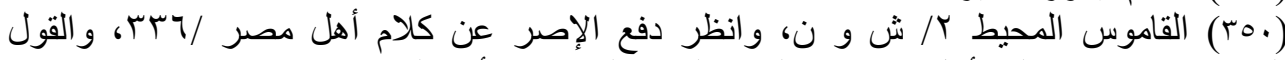

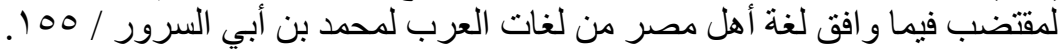

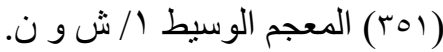

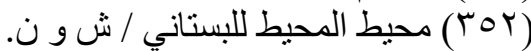

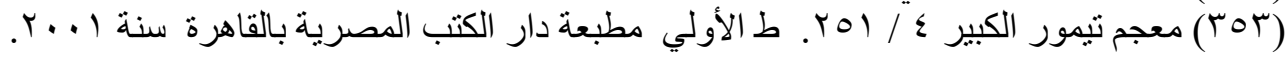


د/ مصطقى عبد الهادي عبد الستار محمد

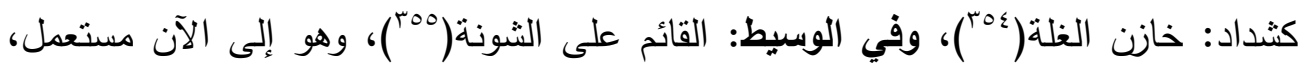

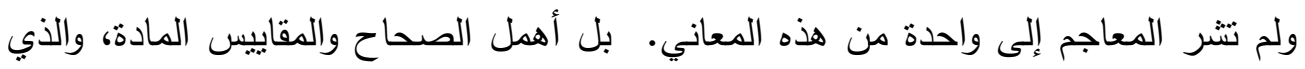

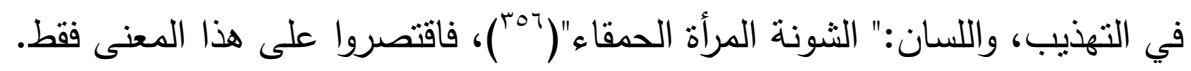

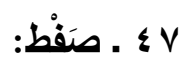

مما استدركه الثيخ الزبيدي على صاحب القاموس لفظ " الصَفْط"، فقال:" ومما يستدرك عليه صفط لغة في سفط بالسين اسم لقرية من قرى مصر ، وسبع عشرة قرية كما تقدم، والصاد نقله الصاغاني في التبصبر، وقال: هكذا تقول أهل مصر بالصاد: صفط، وقدي وقد

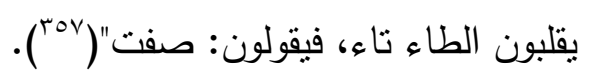

وفي التكملة له أيضًا: صفط: لغة في سفط، لقرى بمصر ذكرها المصنف، قاله

الحافظ، وقال: هكذا يقوله أهل مصر، قلت: وقد يقلبون الطاء تاء(ملهم).

من هذه القرى: صفط راشين، وصفط اللبن، وصفط كرداسة، وصفط نهيا، وغيرها

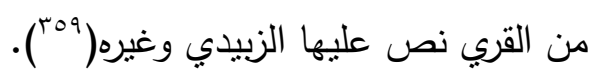

والإبدال الحاصل تارة بين السين والصاد، وتارة أخرى بين الطاء والتاء لله ما يسوغه صوتيا في الفصحى(. بr)، قصد منه تحقيق التتاسب والانسجام بين أصوات الكلمة، فابدل العامة من السين صادا لتماتل الطاء بعدها في الاستعلاء، فقالوا: صفط، ومن قال: صفت فأبدل الطاء تاء فلأن الطاء أخت التاء في المخرج، وقد قالوا في فسطاط: فستاط، فالتاء فيه

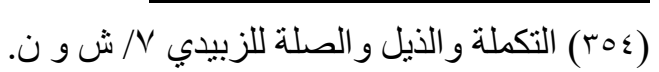

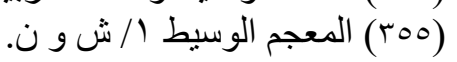

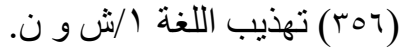

(rov)

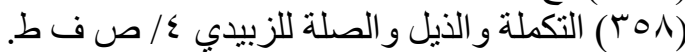

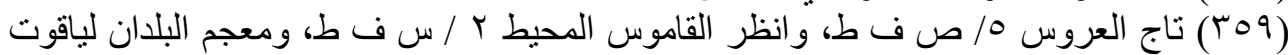

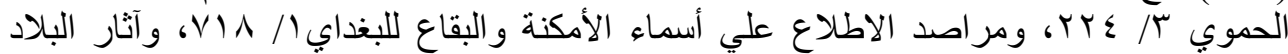

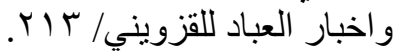

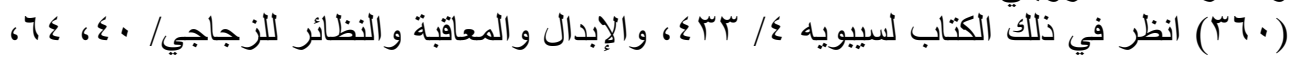

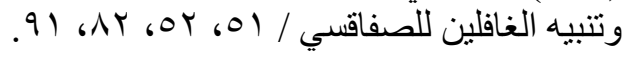


ما نسبه الزبيدي في تاج العروس إلى اللهجة المصرية

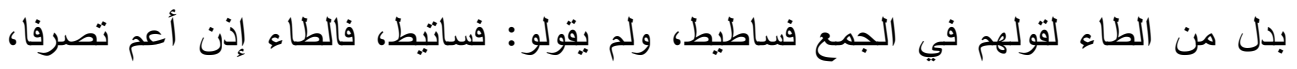

$$
\begin{aligned}
& \text { وقالوا: استاع يستيع أب: }
\end{aligned}
$$

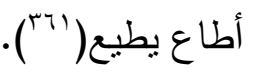

$$
\begin{aligned}
& \text { 1 ـ ـ الصَّنْط : }
\end{aligned}
$$

قال الزبيدي:" الصنط: أهمله الجوهري، وصاحب اللسان، وهو القرظ، هكذا ينطق به

$$
\text { أهل مصر ، وهي لغة في السنط بالسين"( ("T)). }
$$

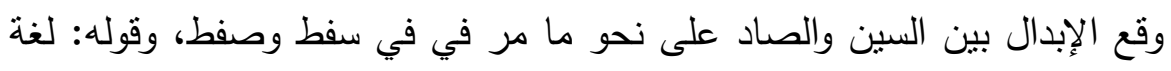

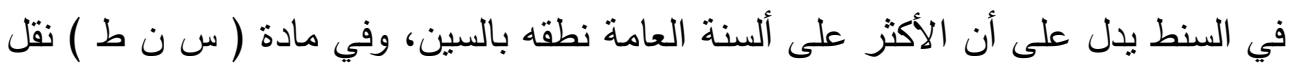

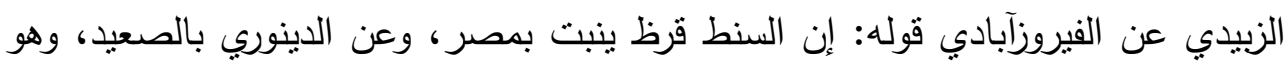

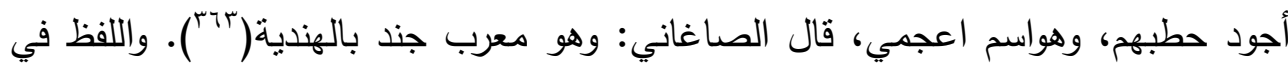

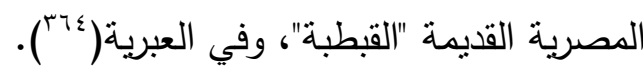
والذي في المجم الوسيط:" السنط: شجر من الفصيلة القرنية ثمره القرظ، بعيش في

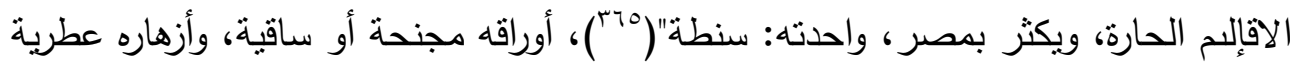

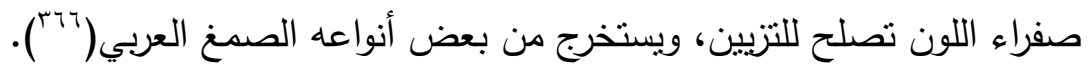
9 ؛ ـ الصيادية : ذكر الزبيدي أن الصبادية أرز بطبخ بالسمك عامية (ҮrV)، وهو في هذا الموضع

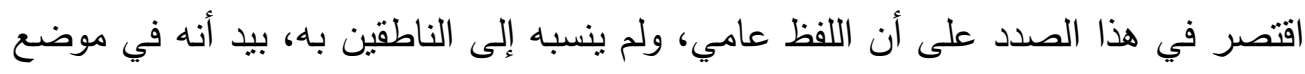

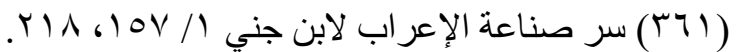

$$
\begin{aligned}
& \text { (بT) }
\end{aligned}
$$

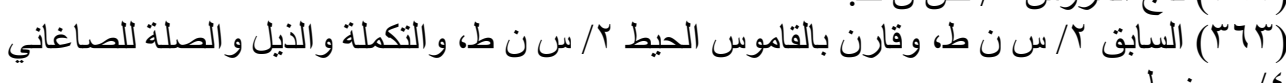

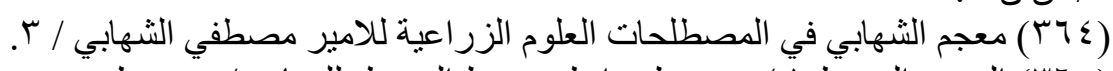

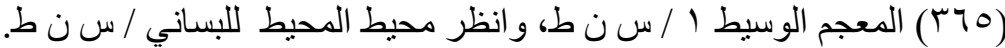

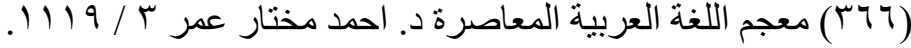

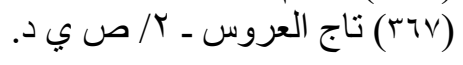




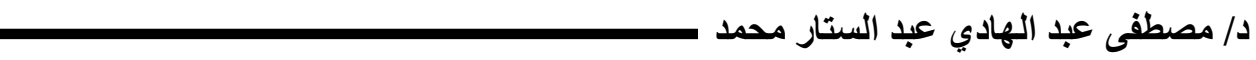
آخر كان أكثر تحديدًا فعزاه إلى إقليمه والناطقين به. قال:" والكوشان الكمان بالفتح طعام لأهل

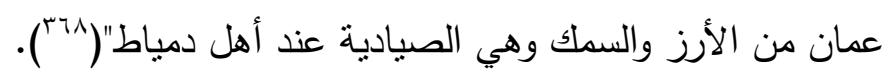
فما يسميه أهل عمان "الكوشان" لهذا الطعام المتخذ من الأرز مطبوخًا بالسمك

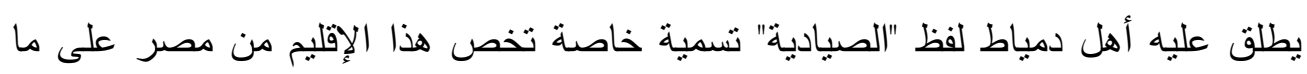

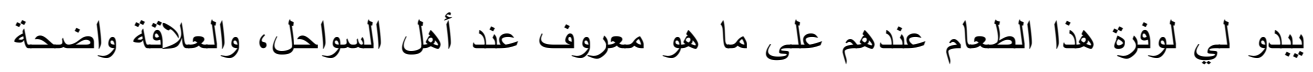

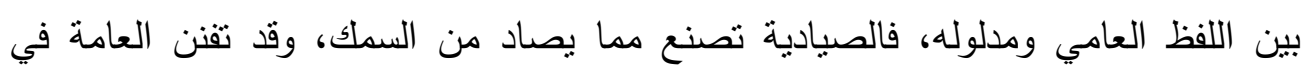

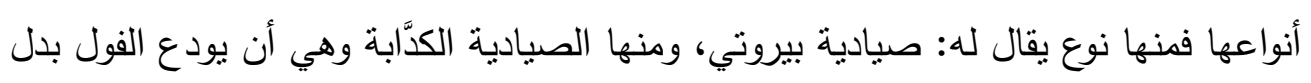

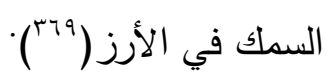
• . 2.

ذكر الفيروزآبادي أن الطبوع كتتور دوبية ذات سم، أو من جنس القردان لعضته ألم

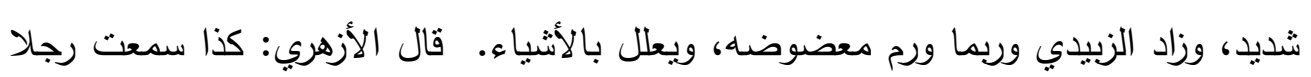

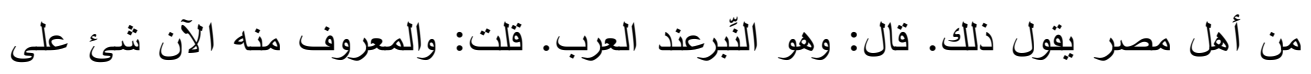

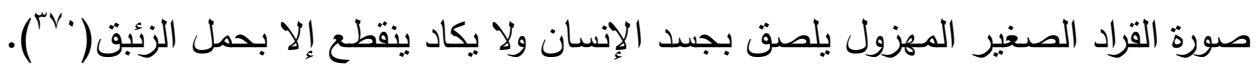
فالطبوع دابة من الحشرات شديدة الأذى( (rآ) من جنس القردان أو القمقام، والقمقام: صغار القردان، وضرب من القمل شديد التشبث بأصول الثعر الواحدة قمقامة، وتسميه

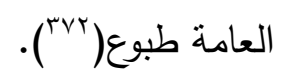

هكذا نص الدميري، وسبق أن نص الزبيدي على أن المسموع عن الأزهري أنه

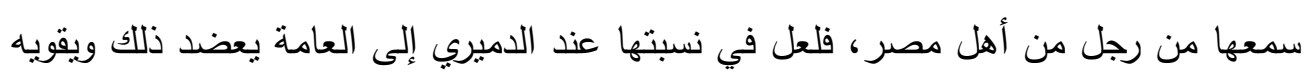

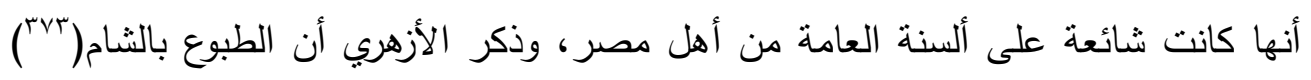
الأرز و السمكابك" السابق / ك و ش، وفي القاموس المحيط / / ك و ش:" و الكوشان: طعام لأهل عمان من

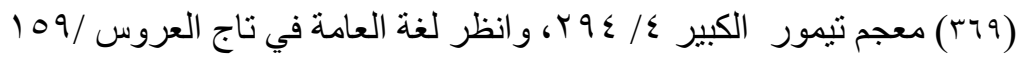

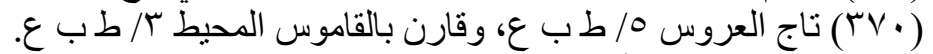

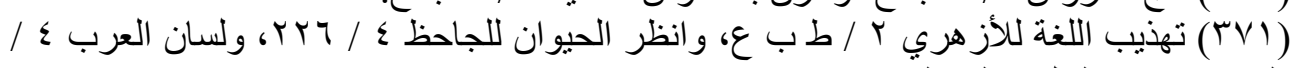

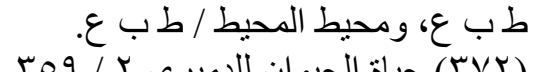

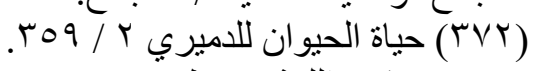

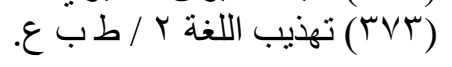


ما نسبه الزبيدي في تاج العروس إلى اللهجة المصرية

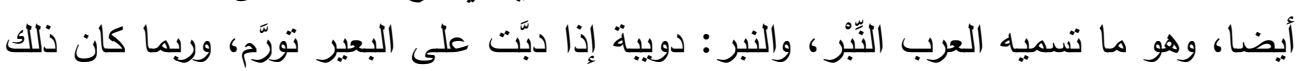

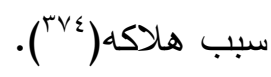

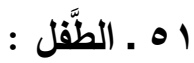

الطفَّلُْ ذلك الطيم اليابس الأصفر المعروف في اللهجة المصرية نص عليه الزبيدي في أكثر من موضع معزواً إلى ناطقيه، فما استدركه على صاحب القاموس المحيط:

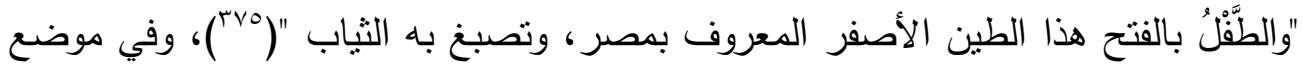

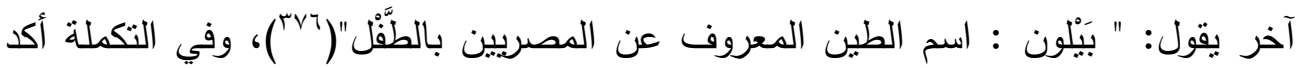
على ما ذهب إليه في التاج، فبيلون كجيرون الطين الأصفر المعروف عند المصريين

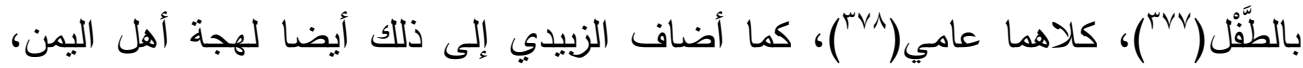

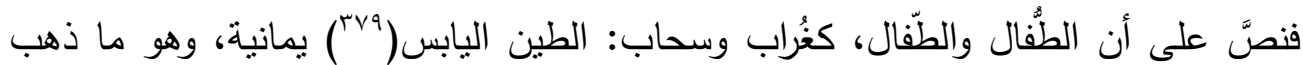

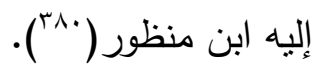

وبناء على ما سبق فالطَّل طين أصفر ، عرف عند المصربين فاتخذوه لصبخ الثياب، وعبارة المعجم الوسيط: الطَّلق: طين أصفر يتجمد على هيئة رقائق بتأثنير ضغط ما فوقه

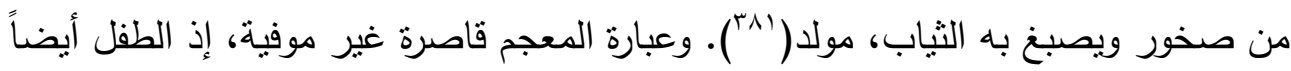
يتخذ منه الطوب للبناء، وتُصنع منه الأواني الفخارية، ولا يبعد أن تكون هذه التسمية لهاريا

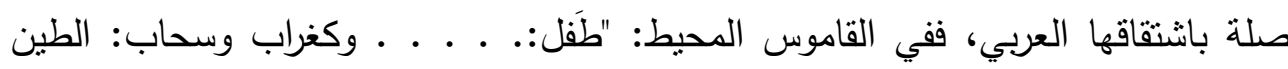
اليابس(r/rr) "، وقد سبق أن بينّا أن ذللك في لغة اليمن.

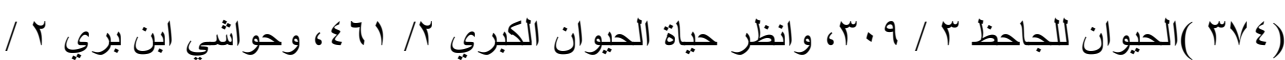

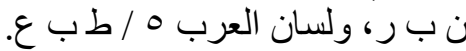

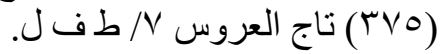

$$
\begin{aligned}
& \text { السابق V (YVT) }
\end{aligned}
$$

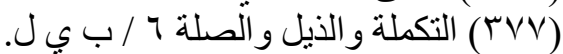

$$
\begin{aligned}
& \text { معم تيمور الكبير \& \& / (TVA) }
\end{aligned}
$$

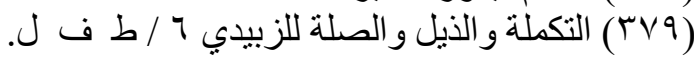

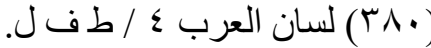

$$
\begin{aligned}
& \text { ) }
\end{aligned}
$$

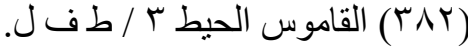




$$
\begin{aligned}
& \text { د/ مصطفى عبد الهادي عبد الستار محمد }
\end{aligned}
$$

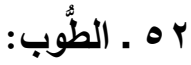

نقول في عاميتتا " طُوب " واحدته طُوبة لهذا اللَّبِن، الذي ينخذ في البناء، وقد عرض الزبيدي لهذا اللفظ بما فيه من خلاف بين اللغويين. قال: " الطوب بالضم: الآجر، أطلقه المصنف كالأزهري في التهذيب، فيظن بذلك أنه عربي، والذي قاله الجوهري: إنه لغة الغة

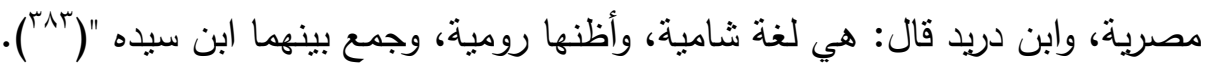

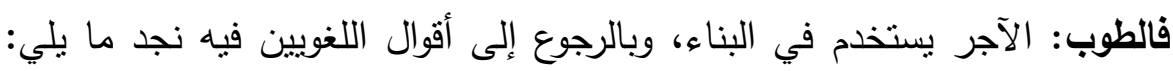

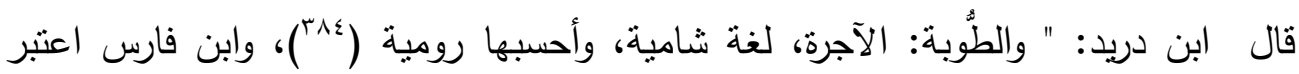

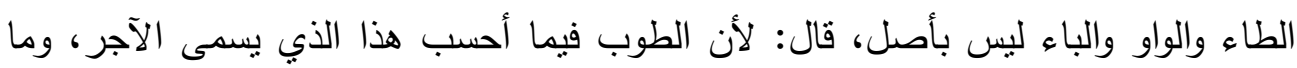

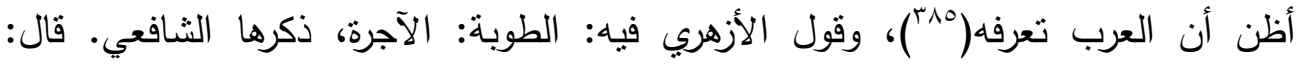

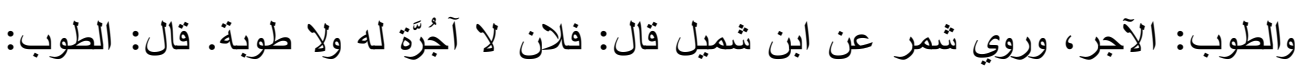

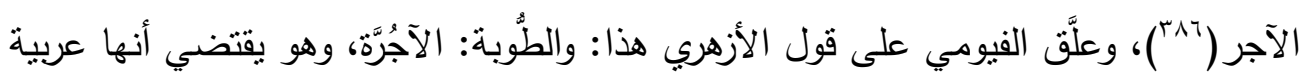

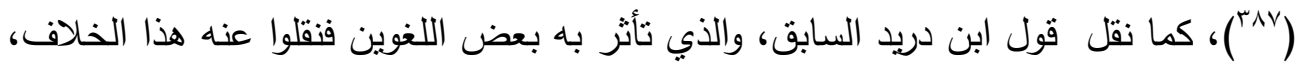

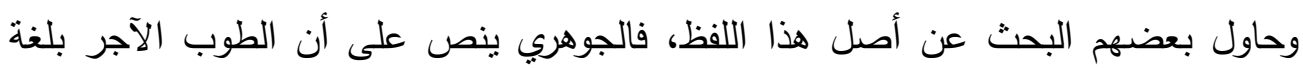

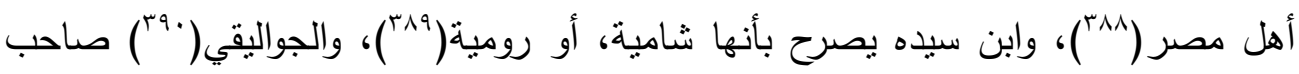

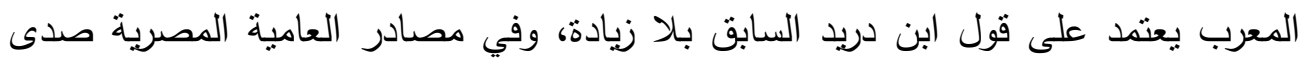
لهذا الخلاف، فالهغربي في دفع الإصرعن كلام أهل مصر يرى أن النان اللفظ صحيح في

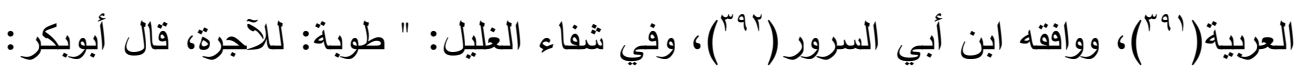

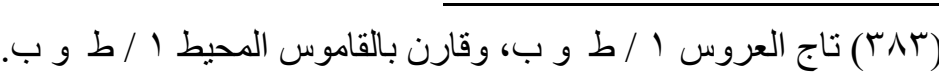

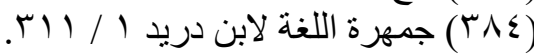

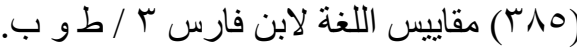

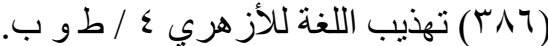

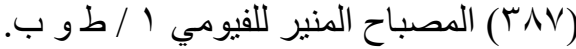

$$
\begin{aligned}
& \text { (r^ᄉ) }
\end{aligned}
$$

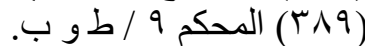

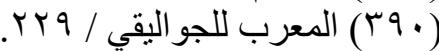

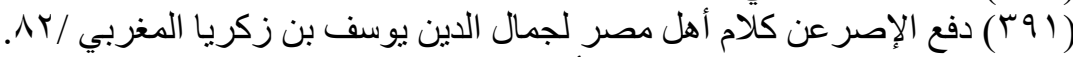

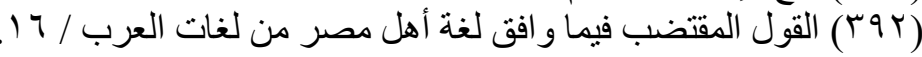

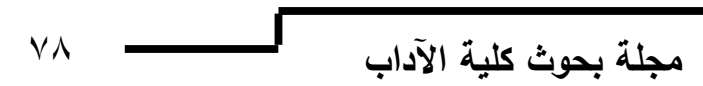


ما نسبه الزبيدي في تاج العروس إلى اللهجة المصرية

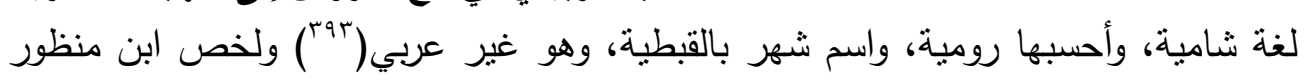
هذه الأقوال جميعها وزاد على ما نص عليه الأزهري في قول ابن شميل: " فلان لا آجرة له له آله

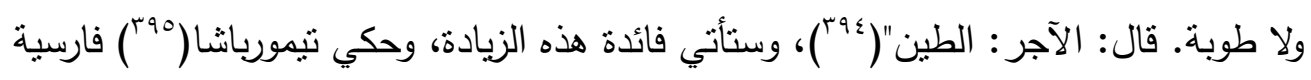

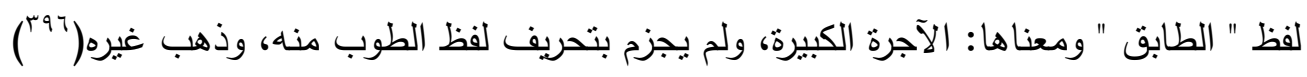
إلى أنها لغة مصرية قديمة، وقد ثأثر المعجم الوسيط بهذه الأقوال، فلم بقطع فيها بقول، وإن ونجان

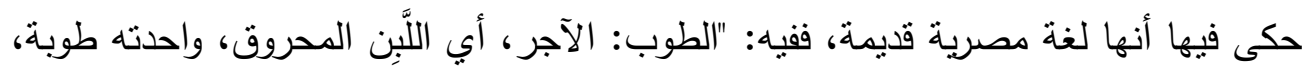

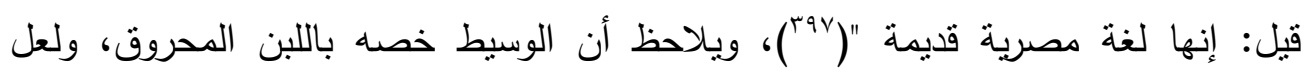

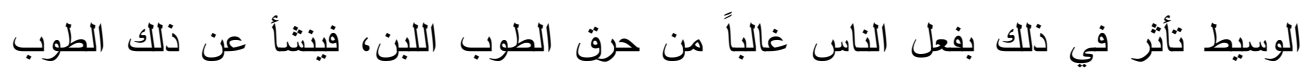

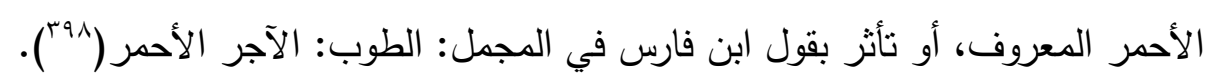
والأمر في تقديري أن اللفظ عام في كل طوب سواء أحرق أم لم يحرق ( اللّنِن

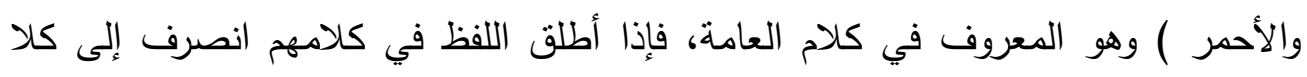
الصّّنفين من غير تخصيص، ولنا في قول ابن شميل السابق: الآجر: الطين بُرْهان يزيد

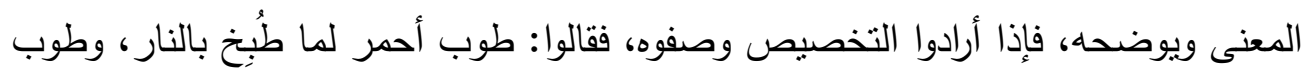

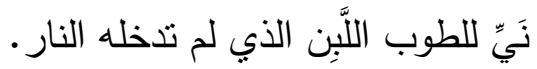

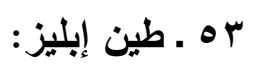

طين الإبليز بالكسر: طين مصر، وهو ما يعقبه النيل بعد ذهابه عن وجه

$$
\text { الأرض ، أعجمية، والعامة تقوله بالسين( ب9 بوَ). }
$$

بدل تسوغه العلاقة الصوتية بين الحرفين الزاي والسين على نحوما بينا في لفظ الزَّحافة، وهذا التحديد والتوصيف عند الزبيدي هو ما اعتمد عليه المعجم الوسيط، فقيه:

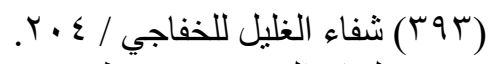

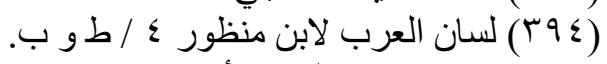

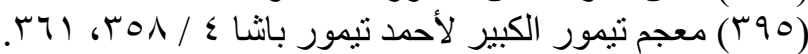

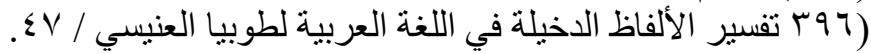

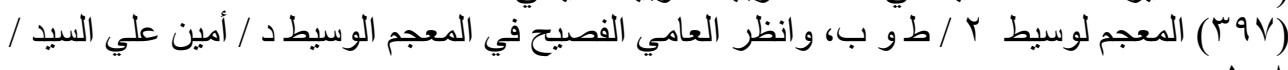


د/ مصطفى عبد الهادي عبد الستار محمد

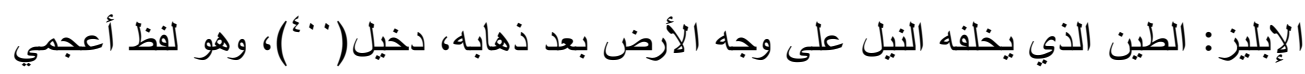
تطور صوتياً على ألسنة المصريين، فنطقوه بالسين على عهد الزبيدي. قال الفيروزآبادي:"

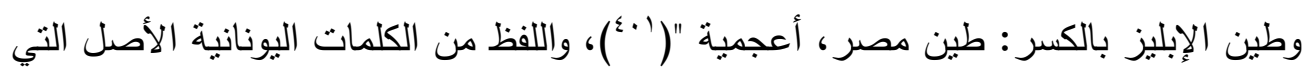

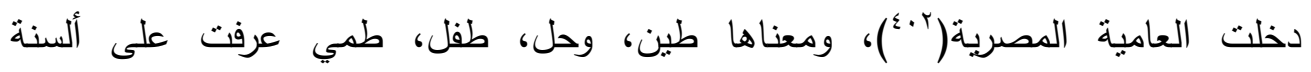

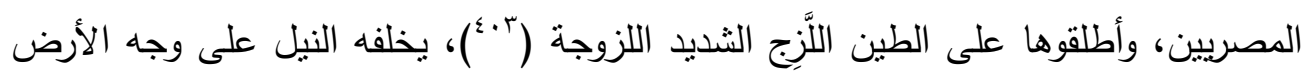

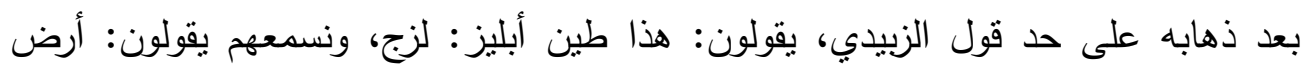

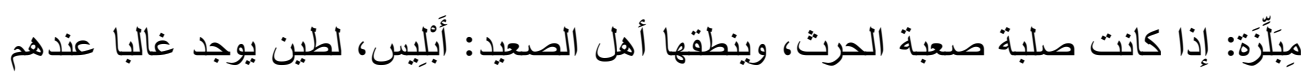

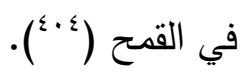

؟ ه . عاط . يعاط . يا عاط:

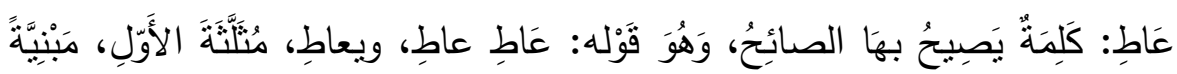

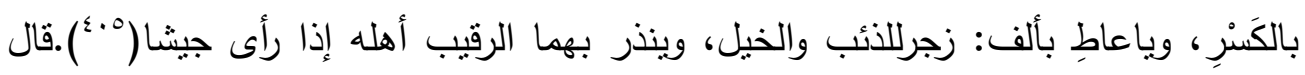
المنتخل الهذلي: ( من الوافر)

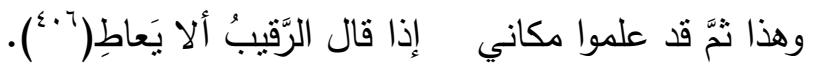

هكذا كان الاستعمال العربي الفصيح، والذي حافظ عليه إقليم الصعيد من مصر على ألسنة العامة، نصَّ على ذلك الزبيدي سماعا منهم مراراً. قال: "وياعاط، بأَلِفٍ، عن من

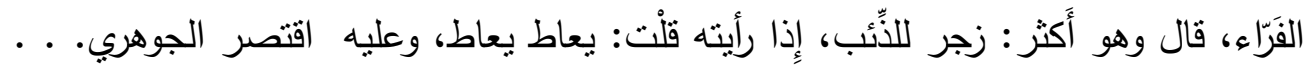

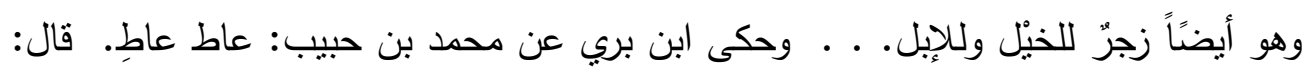

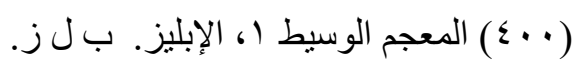

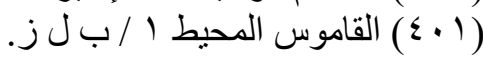

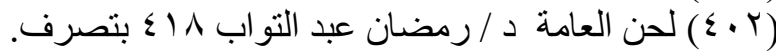

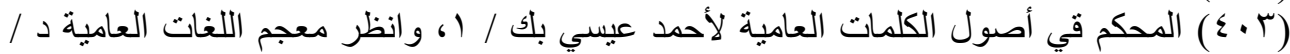

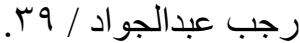

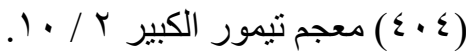

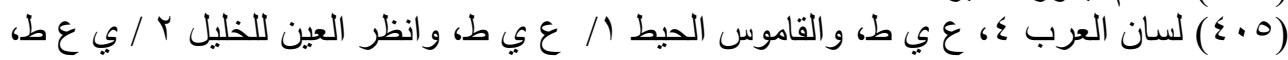

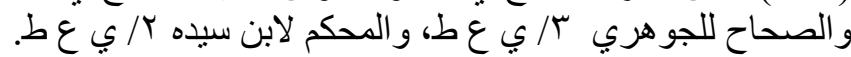

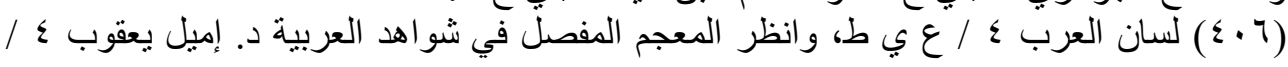




\section{ما نسبه الزبيدي في تاج العروس إلى اللهجة المصرية}

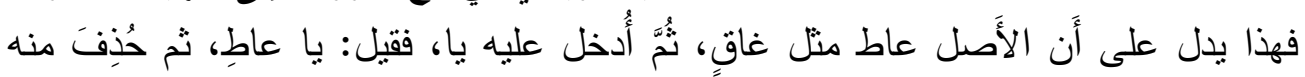

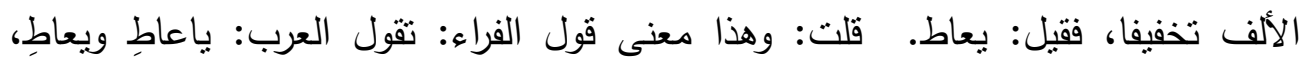

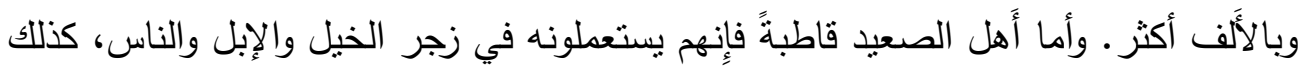

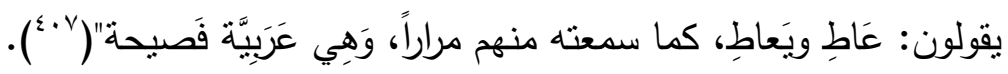

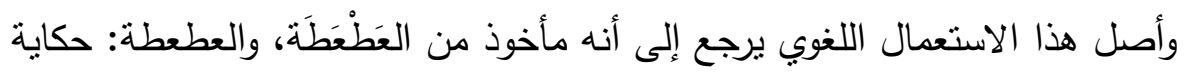

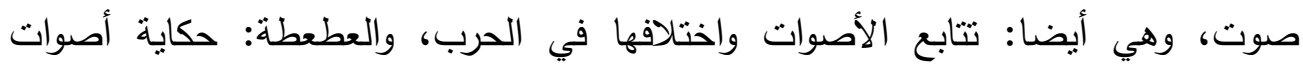

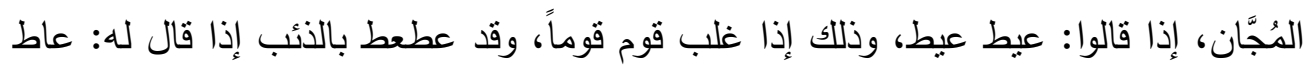

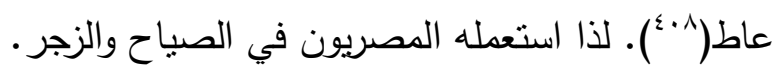

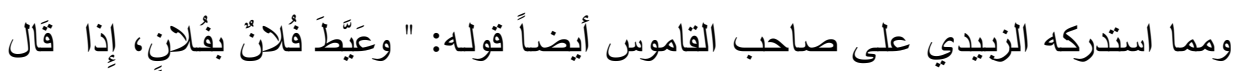

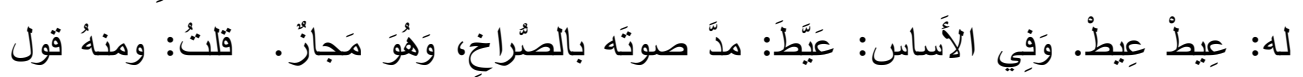

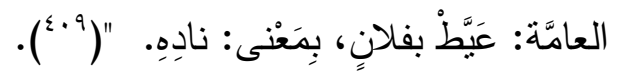

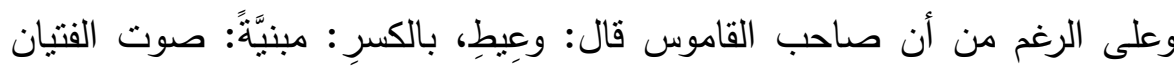

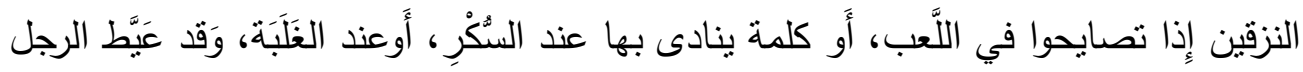

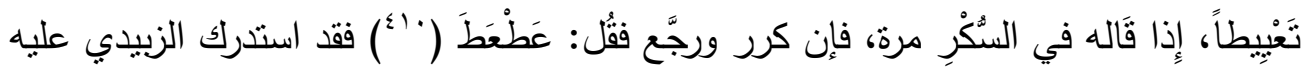

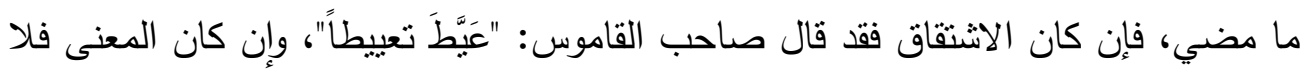

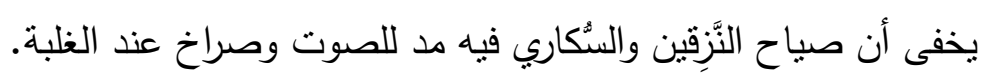

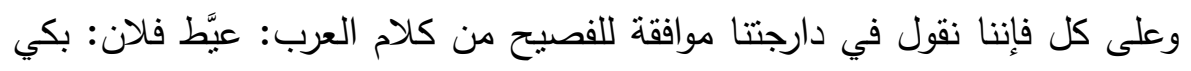

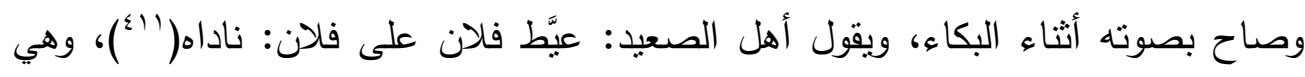

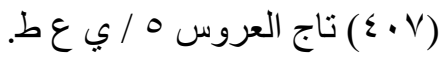

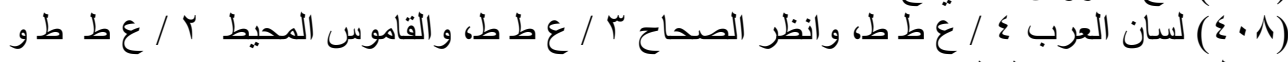

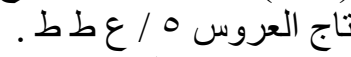

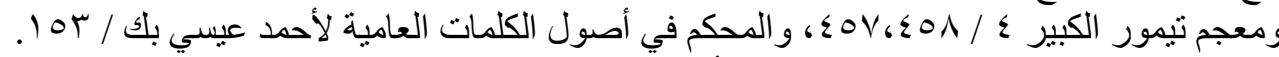

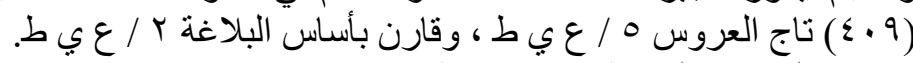

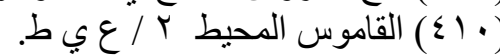

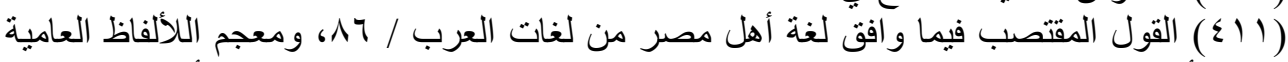

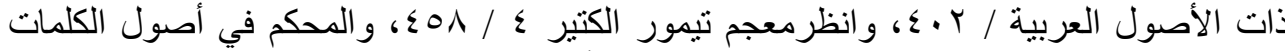

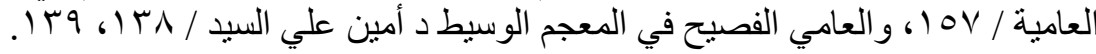




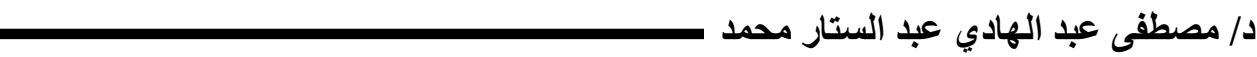

شنائعة في لهجة أهل الثَام، وفي المعجم الوسيط: عَبَّط: صَّاح مرّة وَبكى، والعِياط: الجلبة

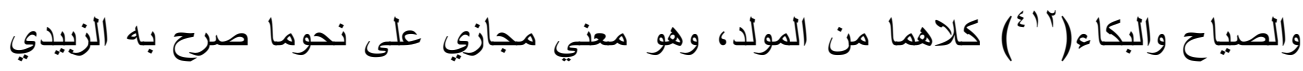

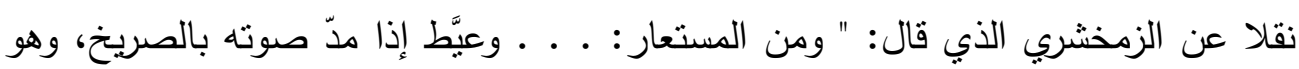

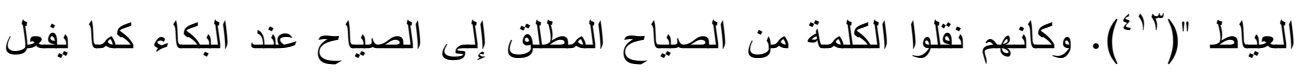

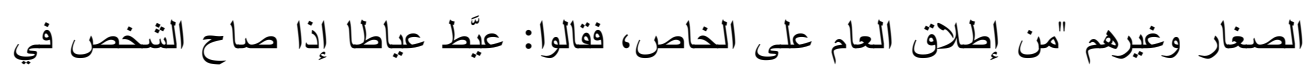

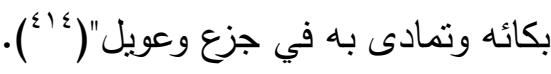

ومن المحدثين من ذهب إلى القول بأن أصله بالهاء بدل العين مأخوذ من الهياط

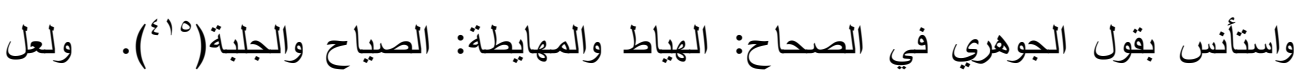
الزبيدي عني بالعامة في كلامه أهل الصعيد لأنهم هم الذين يقولون: عبَّط لي بفلان بمعني: ناده، وسبق أن سمع الزبيدي منهم ذلك مراراً وتكراراً.

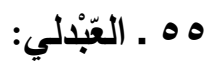

قال الزبيدي:" العَبْدَلّّوي: نوع من البطيخ الأصفر معروف بمصر، منسوب لعبد الله

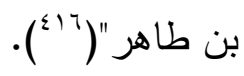

وفي شفاء الغليل ما يؤكد ما ذهب إليه شيخنا في هذا الحرف، فقيه:" عَبْدَبي: نوع من البطيخ، يقال له الخرساني، منسوب لعبداله بن طاهر فإنه الذي دخل به مصر، والعامة

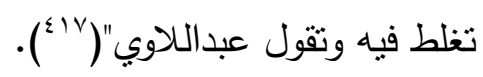

والبطيخ العبدلي هذا قشره أصفر ، ويرجع سبب التسمية بهذا الاسم إلى ما نص عليه شيخنا من أن عبداله بن طاهر أمير مصر " للمأمون"، نظر في دعوى اثثين فحكم لأحدهما،

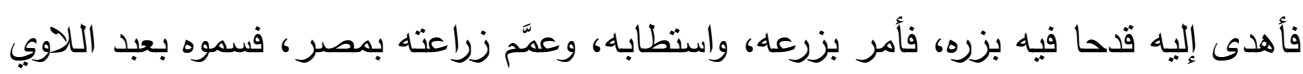

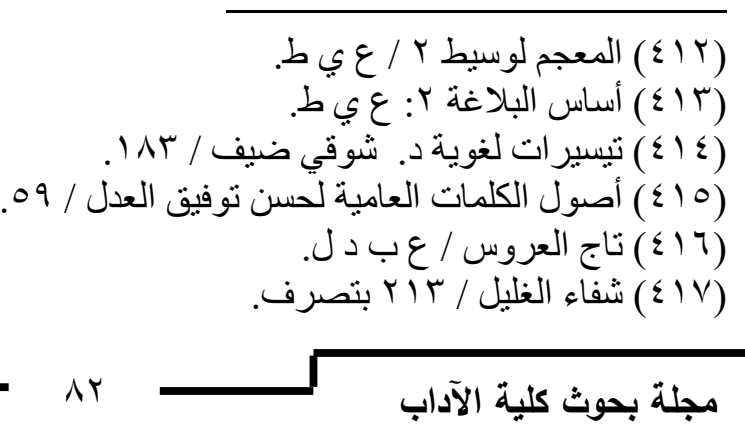


ما نسبه الزبيدي في تاج العروس إلى اللهجة المصرية

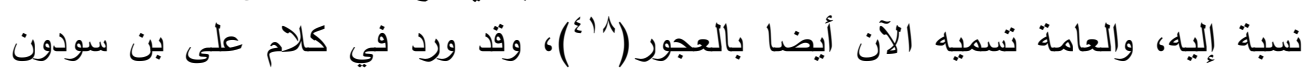
الجركسي المصري من أعلام الأدب المصري الساخر في عصر الدولة المملوكية( • (1 هـ

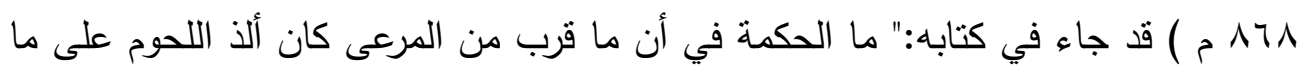

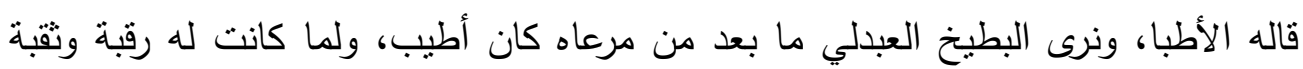
دون غيره من البطيخ"( (19). استدرك الزبيدي على صاحب القاموس المحيط هذا اللفظ في الاستعمال المصري

له. قال: "ومما يسادرك عليه :. . . . وعين الجمل: الثَّاهبلوط مصرية"( .بء). وظاهر الأمر أن إطلاق المصربين هذه التسمية على هذا النوع من الثمر كان على ومعلى

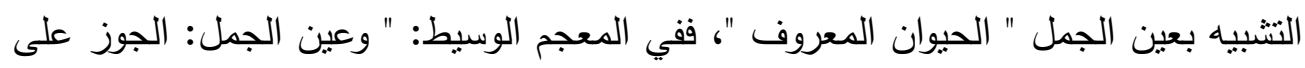

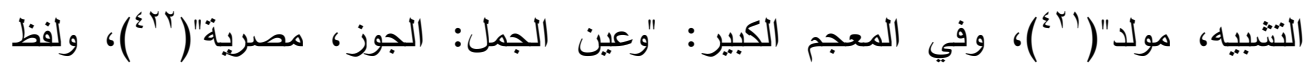

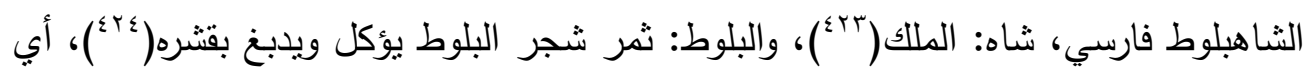
بلوط الملك.

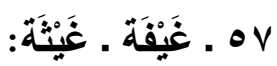

غَيْفَة: قرية مصرية وردت على ألسنة المصريين فيما قبل عصر الزبيدي. قال

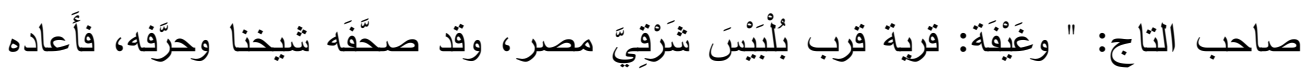

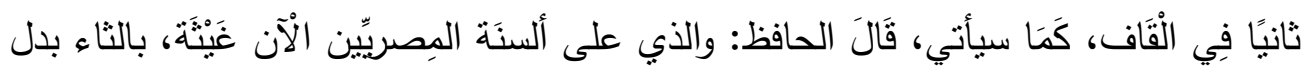

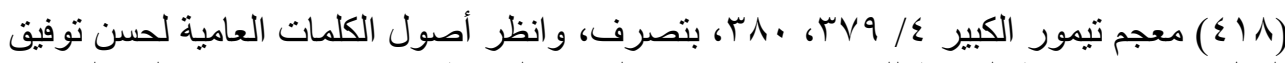

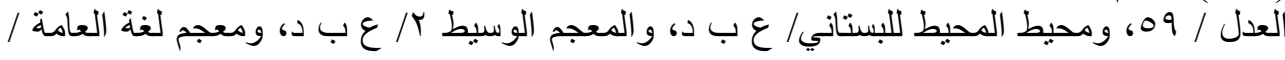

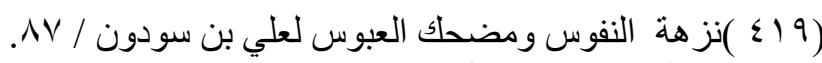

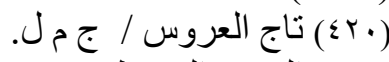

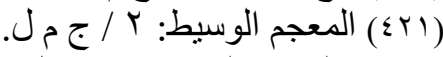

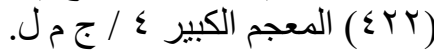

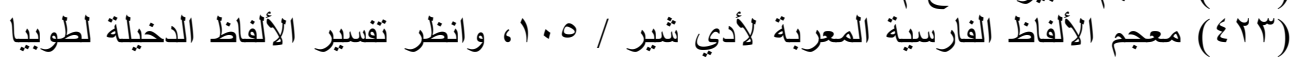




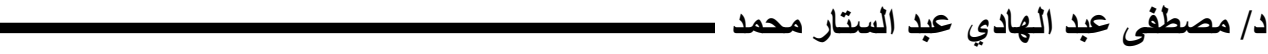

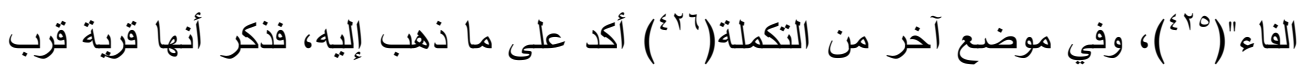
بلبيس. وغيفة: بفتح أوله وسكون ثانيه وفاء ثم هاء، يقال: أغفت الثجرة فغافت، وهي

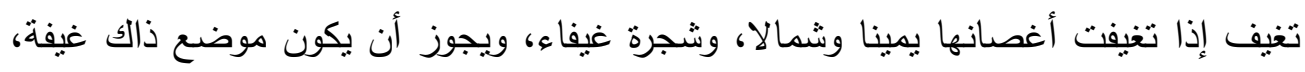
وهي ضيعة قرب بلبيس، ينزل فيها الحاج إذا خرجوا من مصر، ينسب إليها أبو على حسين

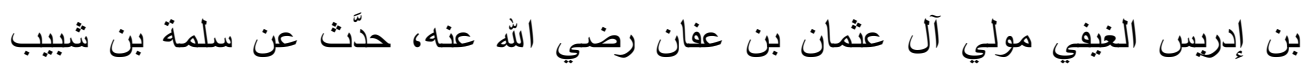
وغيره("Yr)، والعلاقة الصوتية بين الثاء والفاء تسوغ هذا التطور الحاصل على على ألسنة المصريين في نطقهم لهذا الاسم علما على قرية أو قرى لهم، فالثاء والفاء يشتركان فى ولى لهاء الهمس، ويقتربان فى المخرج(^^^)، فالثاء مما بين طرف اللسان وأطراف الثنايا ومن باطن

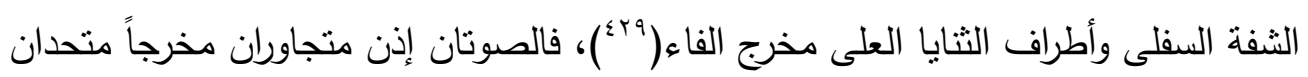

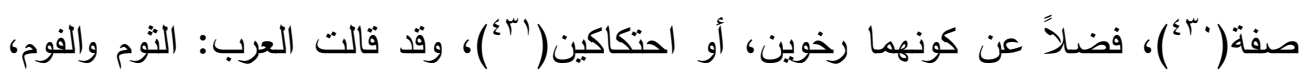

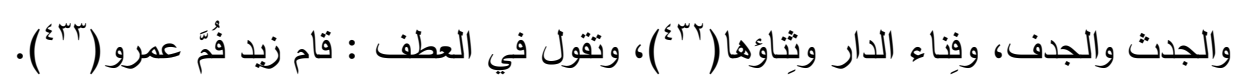

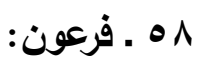

قال الزبيدي: " الفِزْعَوْنُ، كبرزذَذْنِ، وإنَّما أغْفَلَه عَن الضبنطِ لشهرته التمساح بلغَة

القبط"( ) (

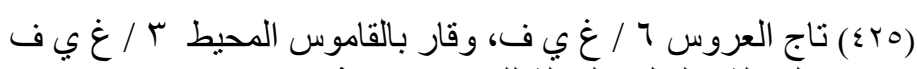

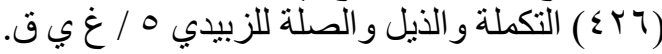

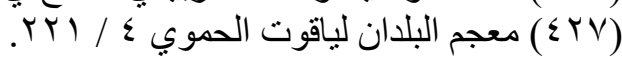

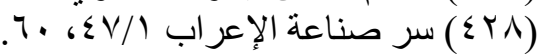

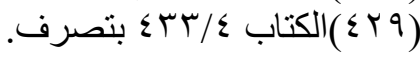

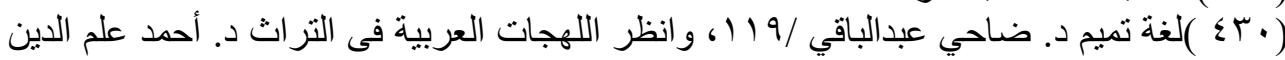

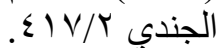

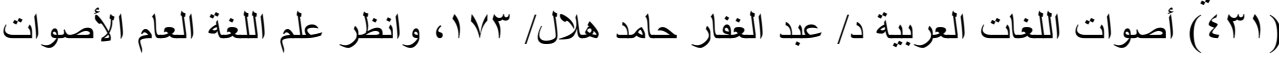

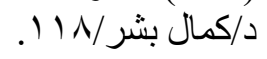

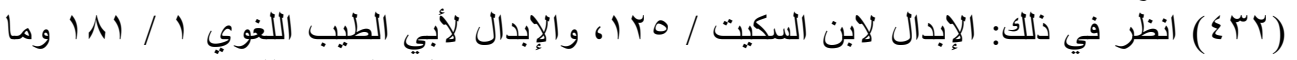

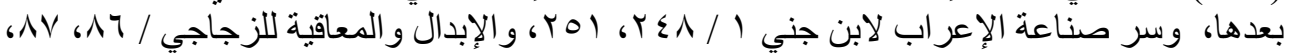

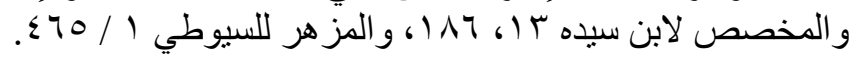

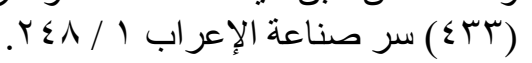

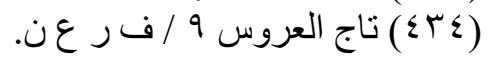


ما نسبه الزبيدي في تاج العروس إلى اللهجة المصرية

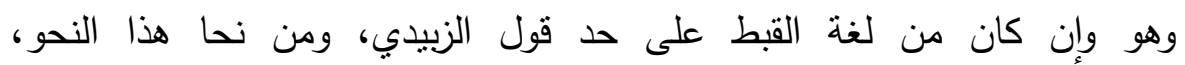

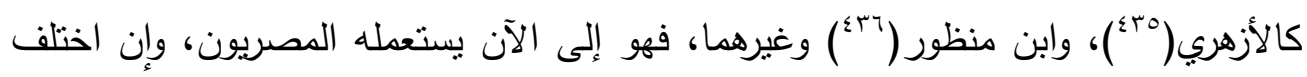

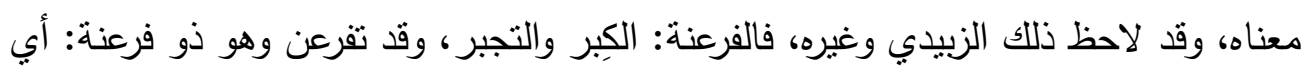

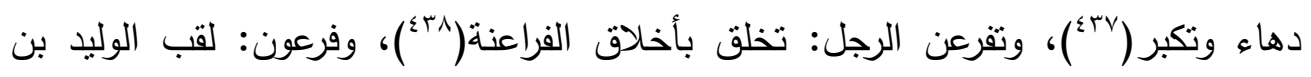
مصعب ملك مصر زمن موسي عليه موسي عليه السلام، والذي ورد ذكره في القرآن

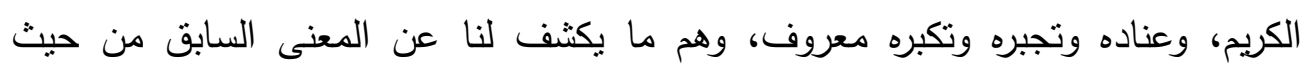

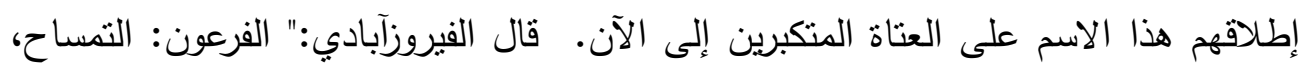

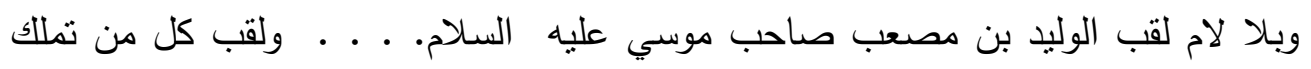

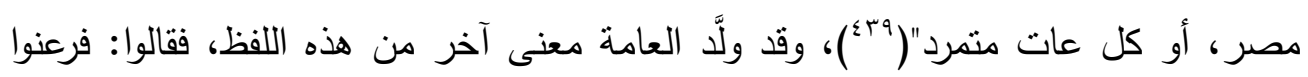
فلاناً: مكنوه أن يتجبر ويطغى( كـ؛ عات). هذا وقد اختلفوا في أصل هذا اللفظ، فذكر ابن دريد أن لفظ فرعون ليس بكلام عربي صحيح( (\$))، وقال أيضاً: "فأما فرعون فلبس باسم عربي، وأحسب النون فيه أصلية، لأنهم

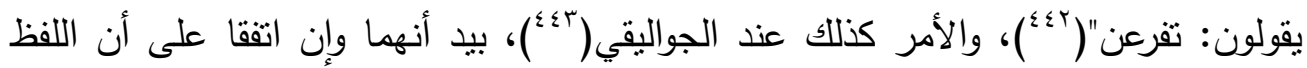

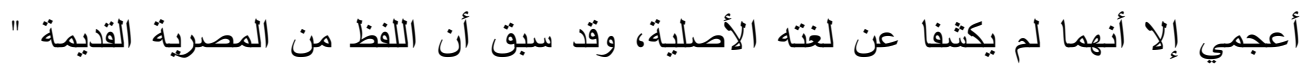
القبطية "، وأخذ بهذا الرأي الأزهري، وابن منظور، والزبيدي فيما سبق، وأيدهم المعجم

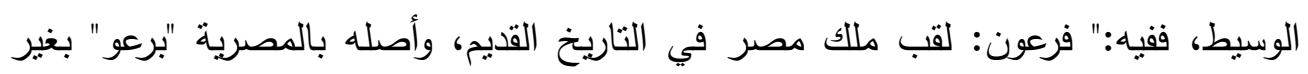

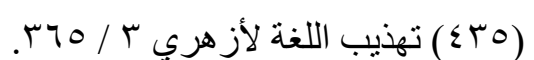

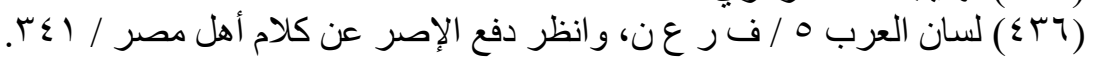

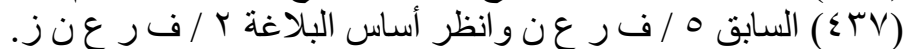

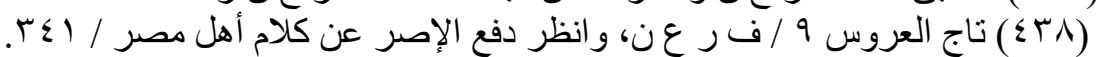

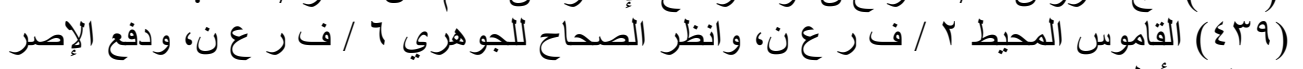

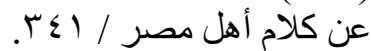

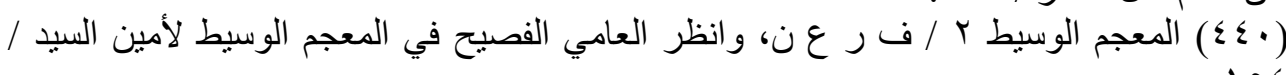


د/ مصطفى عبد الهادي عبد الستار محمد سكاد

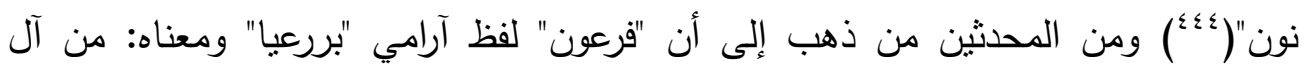

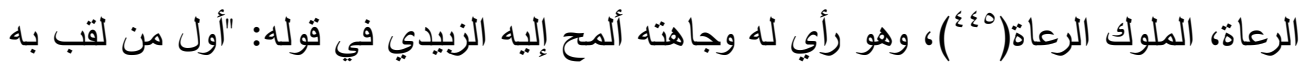

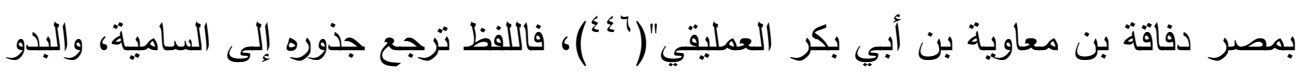

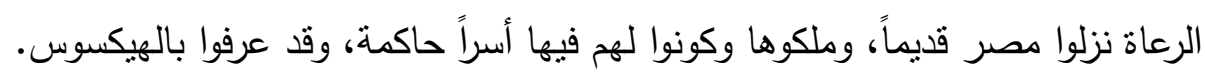

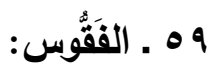

قال الزبيدي: " والفّقّوس كتتور : البطيخ الثامي الذي يقال له البطيخ الهندي، لغة مصرية، وأهل اليمن يسمونه الحبح، هكذا نقله الصاغاني، ولم يذكر أنها لغة مصرية هنا"(

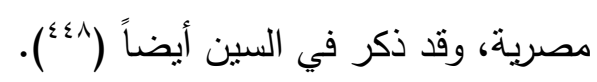
وعليه: فالفقوس في العامية المصرية البطيخ، أوهو البطيخ قبل أن ينضج، ومثله:

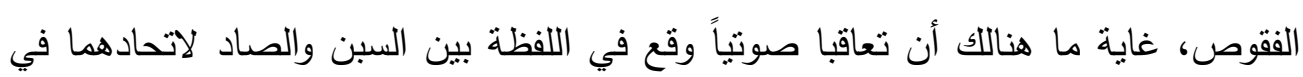
المخرج والاشتراك في بعض الصفات كالصفيروالرخاوة، ويفترقان في صفتي الجهر والهمس،

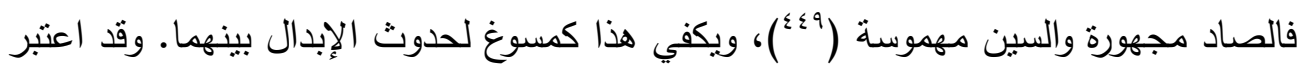
ابن مكي الصقلي الصواب فقوص بالصاد، أما السين فمن نطق العوام من أهل صقلية( (ه). ولعل تسمية المصريين لهذا النوع من البطيخ برجع إلى المشابهة في صغر حجمه بالبيض، وفي قول الزبيدي: "قبل النضج" يقوي هذا المفهوم، يقال: فقص البيضة يفقصها:

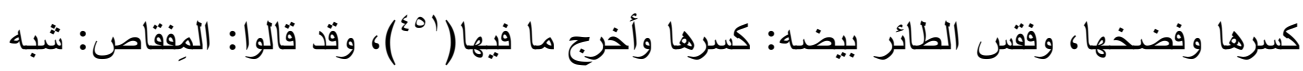

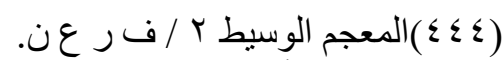

(

(

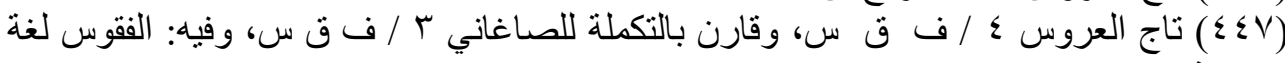

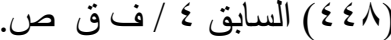

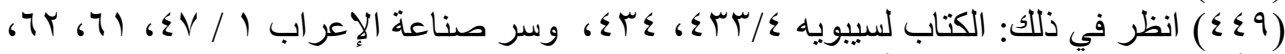

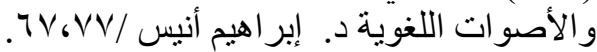

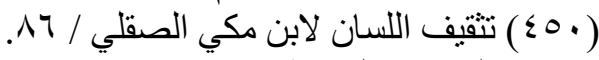

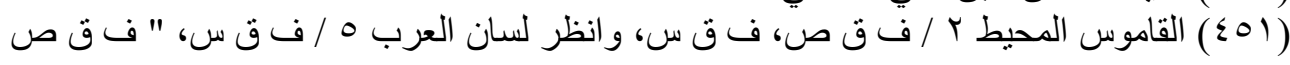


ما نسبه الزبيدي في تاج العروس إلى اللهجة المصرية

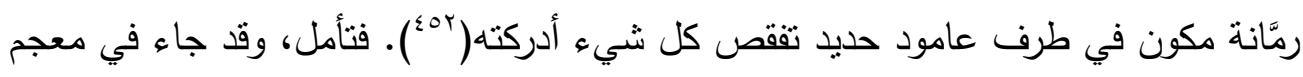

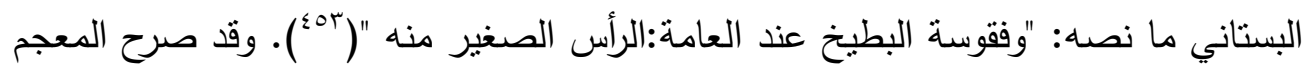

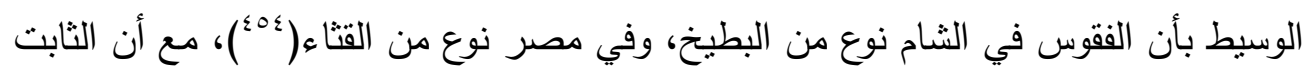

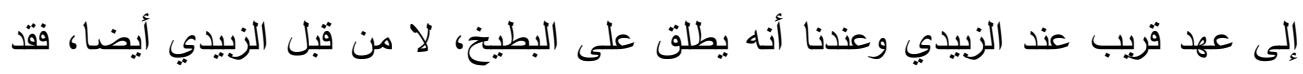

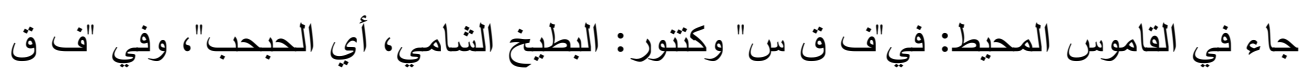

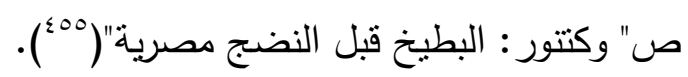

فاللفظة مستعملة عند المصريين والثوام على السواء، ولا أدري لماذا فرق المعجم

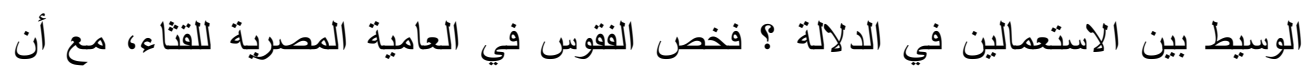

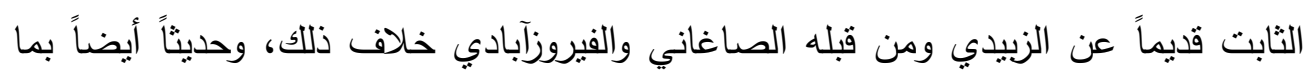

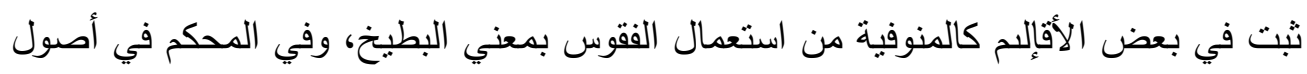

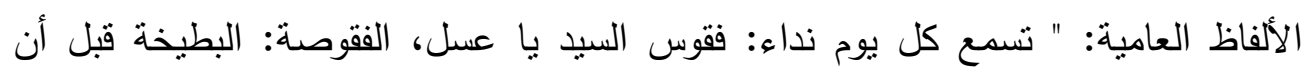

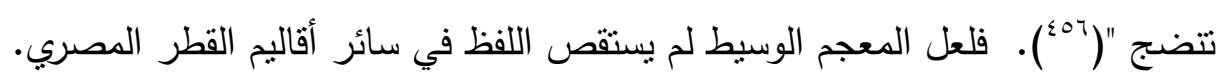
.

يقول الزبيدي:". . . . . وكثر استعمال هذه اللفظة حتي اثتقوا منها فعلا، فقالوا:

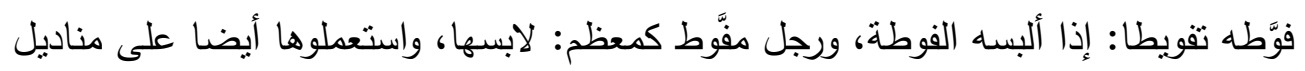

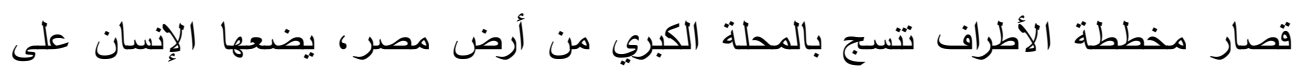

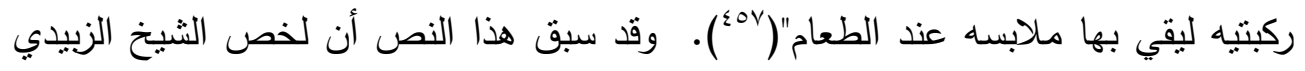

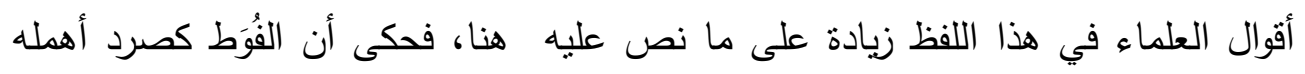

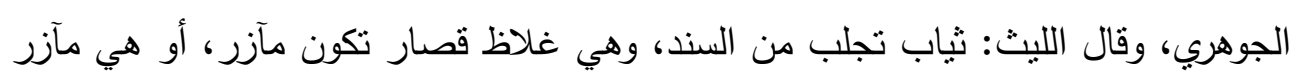

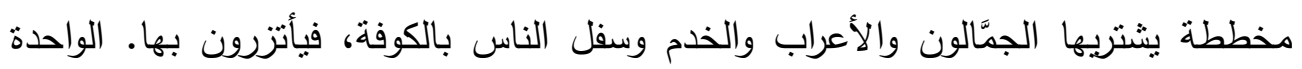

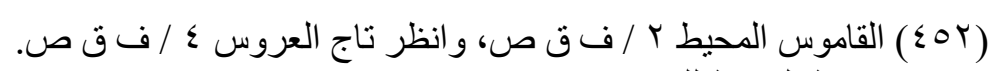
(

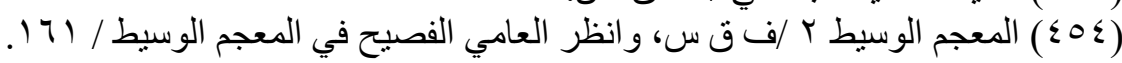

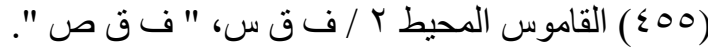

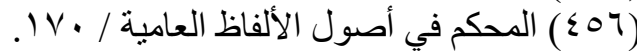

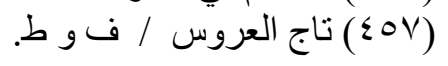

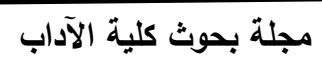

$\wedge \vee$ 


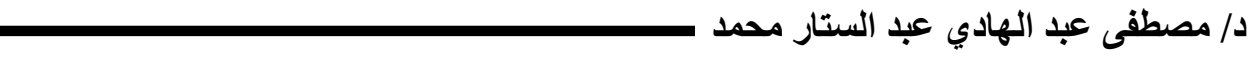
فُوطة بالضم. قاله الأزهري، قال: ولم أسمعها في شئ من كلام العرب، ولا أدري أعربية هي مي العي أم من كلام العجم، وقال ابن دريد: فأما الفوط التي تلبس فليست بعربية، أو هي لغة فئه سندية،

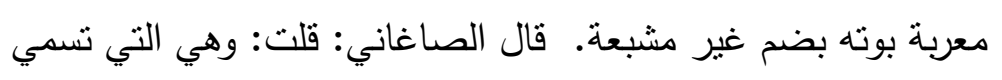
عندنا باليمن الأزهرية(

وهنا انظر كيف انتقل اللفظ، ولاحظ كيف لاحظ الزبيدي الاستعمال في اللهجة المصرية، وربطه بموضع صناعته بالمحلة الكبرى من مصر ، فالفوطة: ثوب قصبر يأتزر به الهن

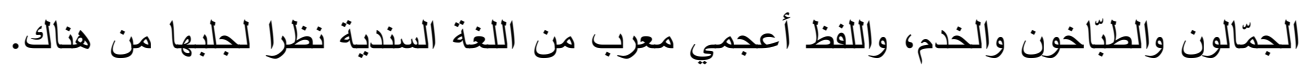

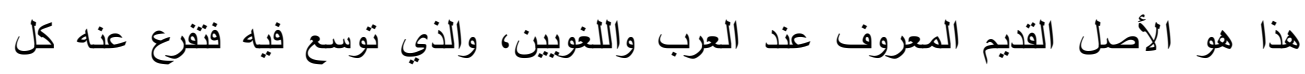
المعاني الأخرى، والتي يمكن تلخيصها فيما يلي: ا. ثوب قصير غليظ يتخذ مئزرا كان يجلب من السند. r ـ إزار فوق الثياب يقيها أثناء العمل، ونسيجه من القطن( فوطة المطبخ). r ـ ثوب من القماش ثخين يجفف به الوجه واليدين وسائر أعضاء الجسم ( مسح وجهاء ونه بالفوطة).

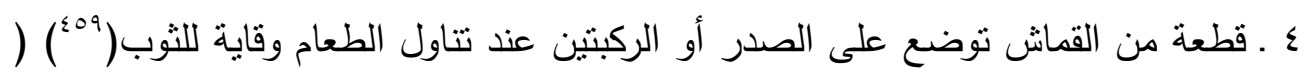
فوطة المائدة )

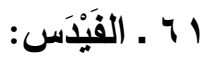

قال الزبيدي:"الفَيْدس كحيدر : الجَرَّة الكبيرة، وهي دون الدن وفوق الجرة، يستصحبها

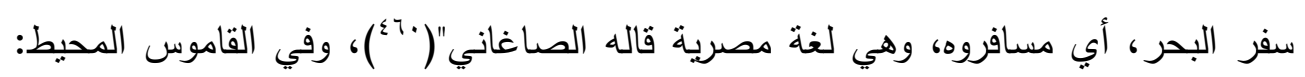
والفيدس: الجَرَّة الكبيرة يستصحبها سفر البحر ، مصرية( (بأ).

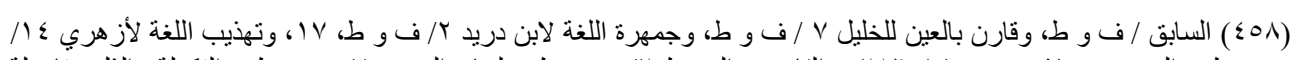

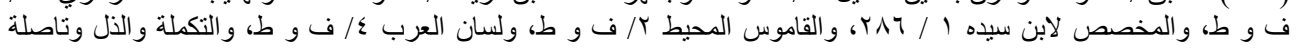

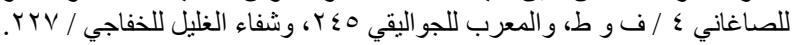

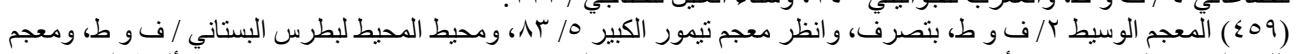

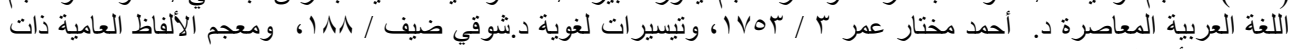

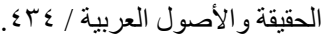

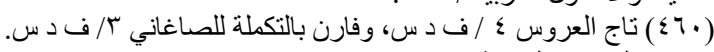

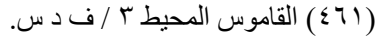


ما نسبه الزبيدي في تاج العروس إلى اللهجة المصرية

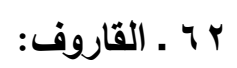

لفظ القاروف من العامية المصرية التي نصَّ عليها الزبيدي استدراكاً على صاحب

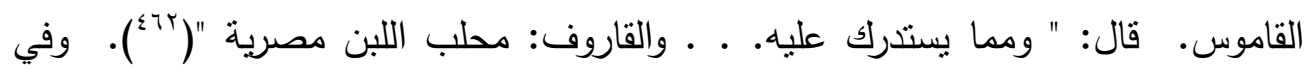

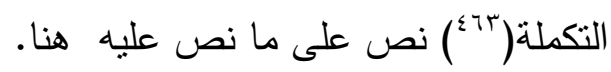
والقَرَّن: وعاء من جلد يدبغ بالقِرفة، وهي قشتور الرمان ويجعل فيه الخلع، وهو لحم

بطبخ بتوابل فيفرغ فيه( (1)؛).

وفي لسان العرب: " القَّزْ: الأَدِيم، وجمعه: قروف. أبوعمرو: القروف: الأََْم

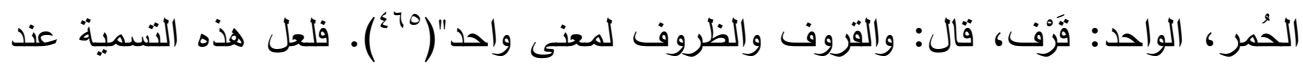

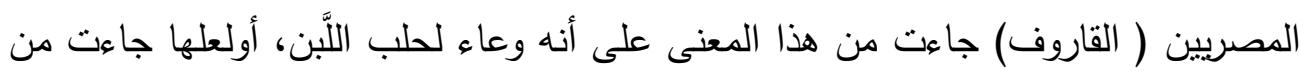

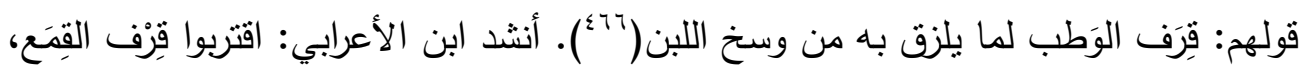

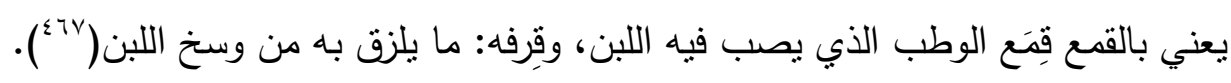

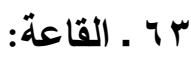

استدرك الزبيدي على صاحب القاموس المحيط القاعة بمعناها المصري. فقال:

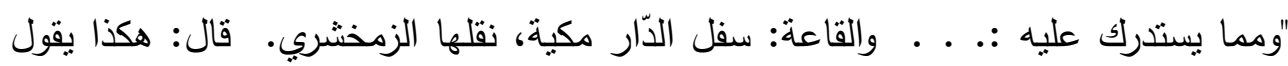
أهل مكة، تقول: قعد فلان في العلية ووضع قماشة في القاعة، قلت: وهكذا يستعمله أهل

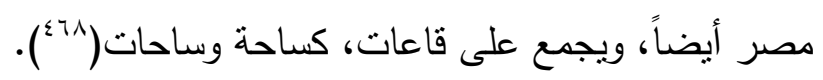

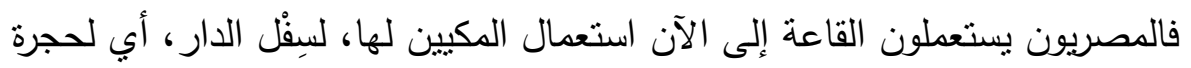

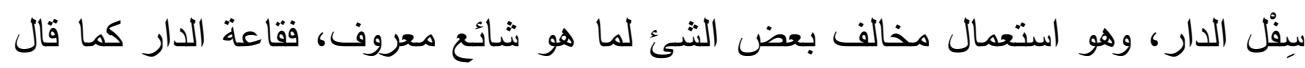

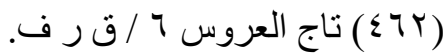

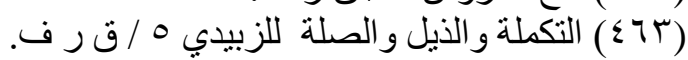

$$
\begin{aligned}
& \text { ( }
\end{aligned}
$$

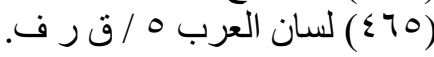

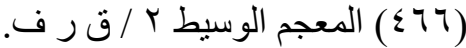

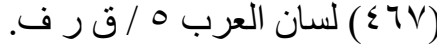

$$
\begin{aligned}
& \text { ( }
\end{aligned}
$$


د/ مصطفى عبد الهادي عبد الستار محمد

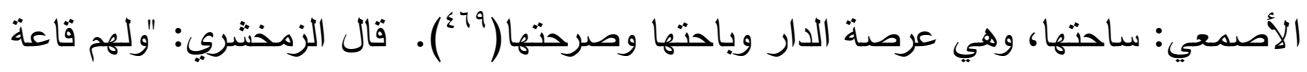

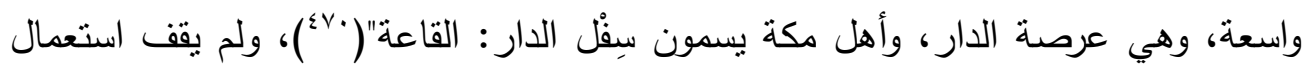

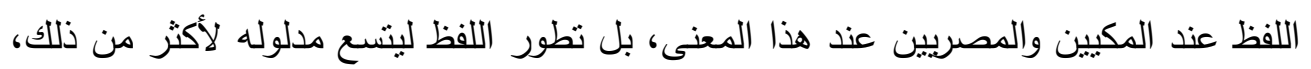

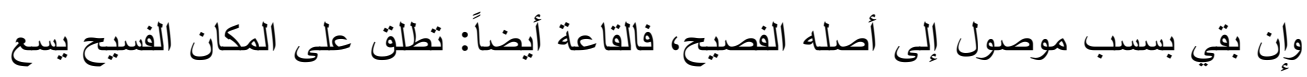
جمعا عظيما من الناس، كقاعة المحاضرات ونحوها. مولد( (V))، وفي معجم تيمور الكبير : " القاعة بمعنى الردهة والبهو لم ترد، وهي عامية، ولكن لا بأس من استعمالها( (بr ع).

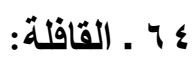

القافلة: الرفقة الكثيرة العدد الراجعة من السفرأو المبتدئة به، يكون معها دوابها

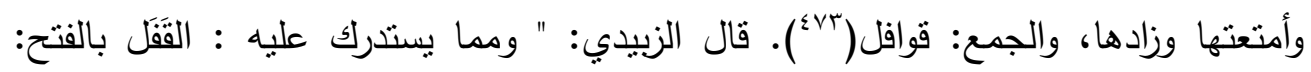

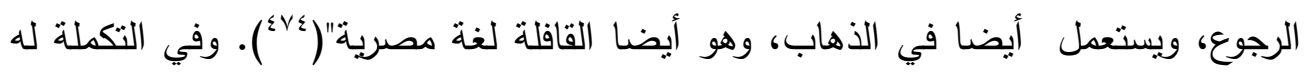

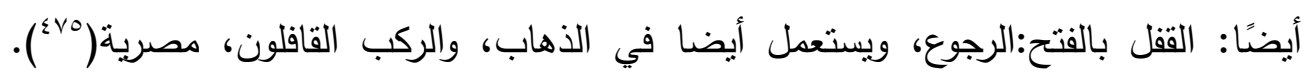
وتأسيسا على ما ذكر فالقلل اسم يلزم الجماعة، جماعة القفال، يقال: قفَل القوم يقفلون قفولا

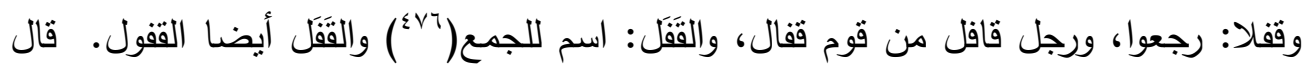

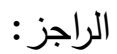

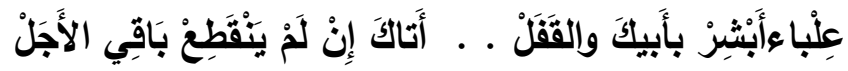

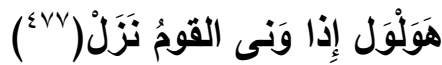

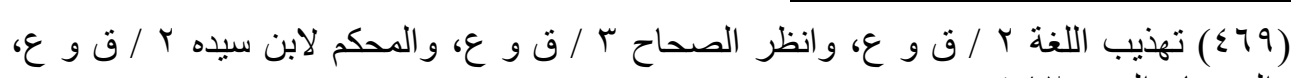

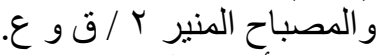

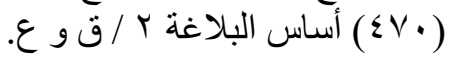

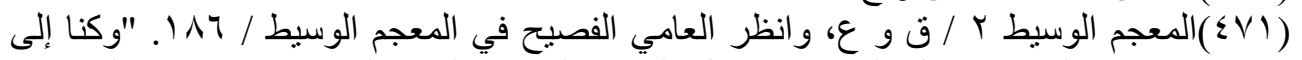

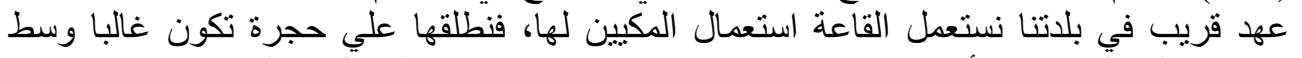

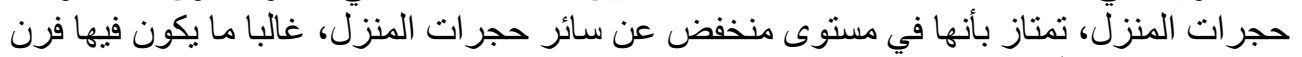

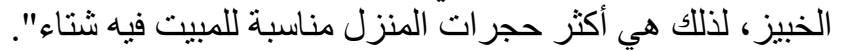

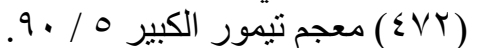

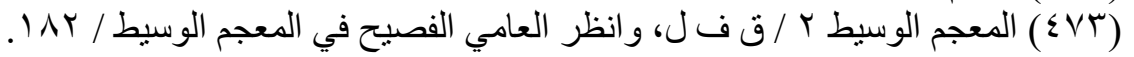

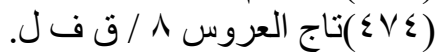
(

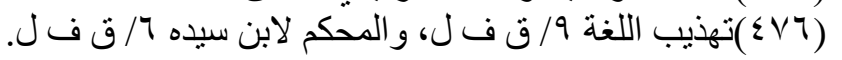

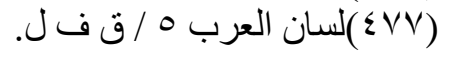

9. 


\section{ما نسبه الزبيدي في تاج العروس إلى اللهجة المصرية}

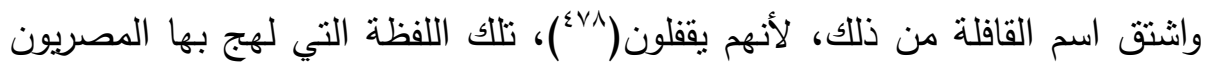

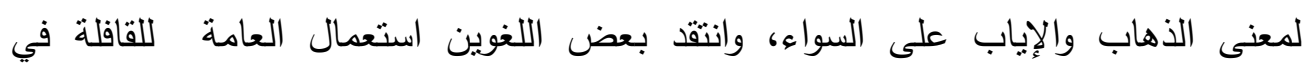
المعنبين "الذهاب والرجوع". قال ابن قتيبة: "القافلة: يذهب إلى أنها الرفقة في السفر ذاهبة

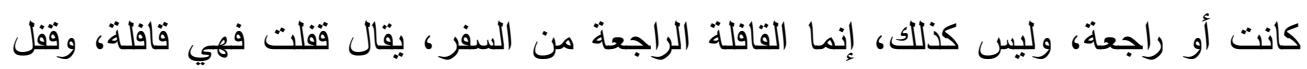

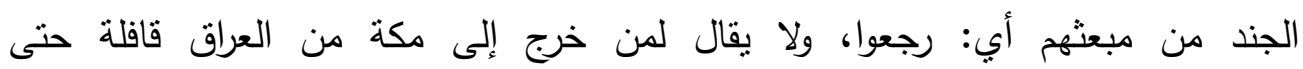

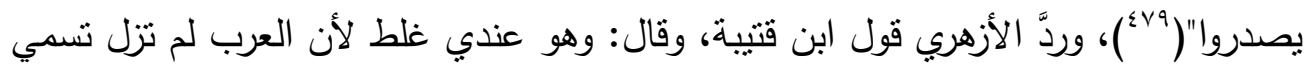

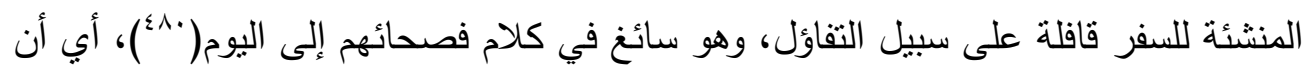
الرفقة سميث قافلة قبل قفولها تفاؤلا بققولها عن سفرها، وهذا كتسميتهم الدُّمل دملا قبل سبل فئل اندماله، واللايغ سليما قبل سلامته، والبيداء مفازة( (ي)، وفي القول المقتضب فيما وافق لغة وهة أهل مصر من لغات العرب: "ويقولون: قافلة. قال في الزاهر: القافلة للرفقة الذاهبين للسفر، ولهاء ولهاء

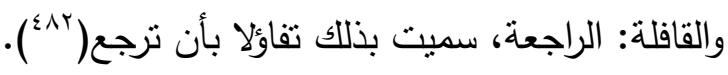

ه 1 ـ القرافة:

قال الزبيدي: " والقرافة كسحابة: بطن من معافر ، بني يعفر بن مالك بن الحرث. . .

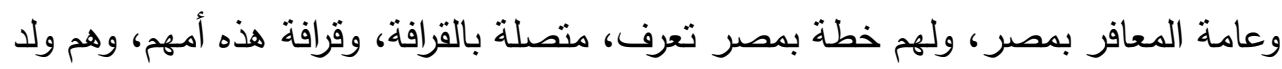
عصر بن سيف بن وائل، بن الحيزي، وبهم سميت مقبرة مصر القرافة( (1^ء).

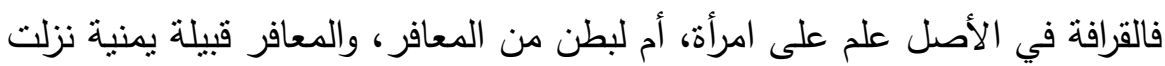
مصر، ولما كان موطنهم متصلا بالمقابر ومساكنهم مجاورة لها سميت هذه المقابر بالقرافة نظرا لهذه الصلة، ثم في مرحلة تالية من تطور اللفظ أضحي مستعملا على ألسنة العامة من من فئن المصريين في أية مقبرة يطلقون عليها اسم القرافة. وفي شفاء الغليل: قرافة: بطن من بطن

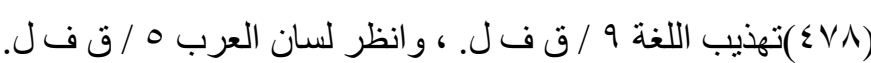

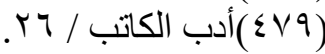

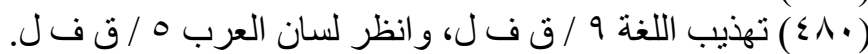

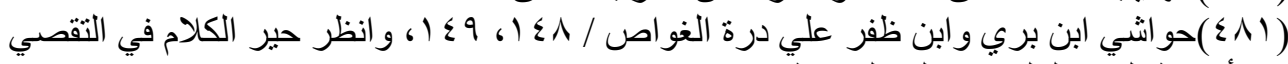

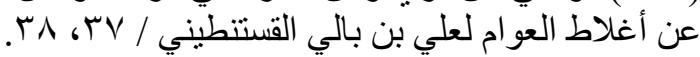

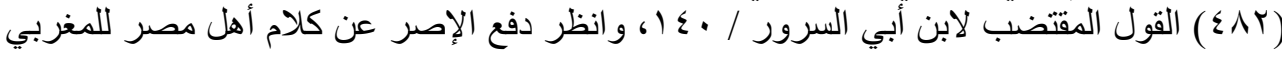

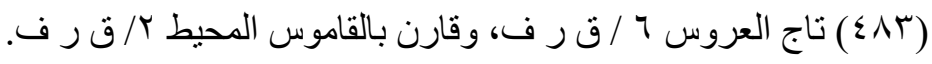




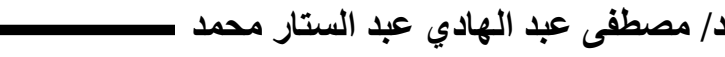

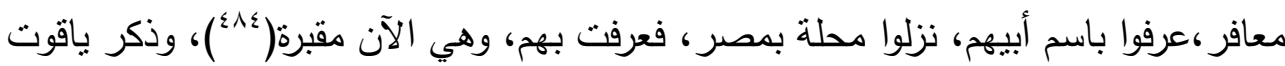

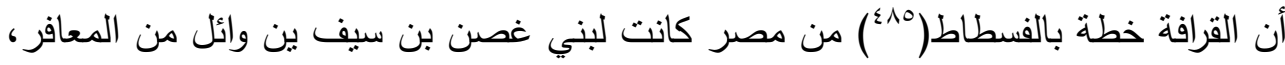

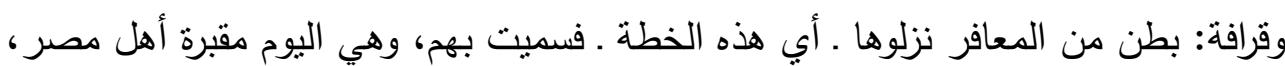

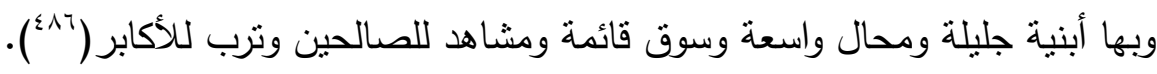
צ

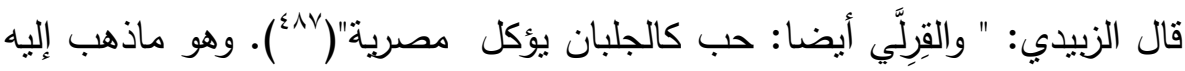
أيضا في النكملة. والذي في دفع الإصر عن كلام أهل مصر : "يقولون: قِرِلَّي نافعة، والقِرِلَّي كِمِكَّي:

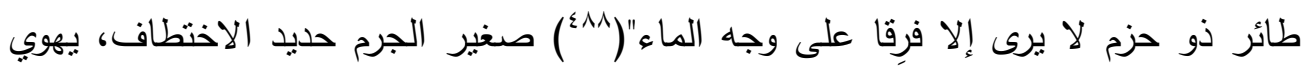

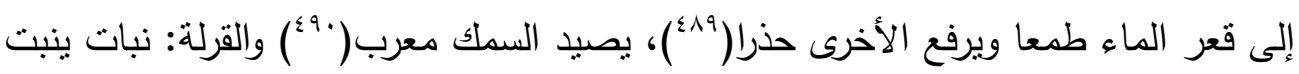
مع الفول يؤكل أخضر ، وأوراقه مثل أوراق الجزر، وبها حرافة تؤكل مع الخبز والجبن ونحو ذللك، وهي معروفة في الوجهين البحري والقبلي(' ؛ول).

ـ IV

في عاميتتا المصرية نقول: القَرْنَيط، لنوع معروف من الزهر يؤكل مطبوخا، والأصل فيه قنَّيط، فقلك ادغام النون المضعفة، وأبدلت الأولى راء وفق قاعدة المخالفة

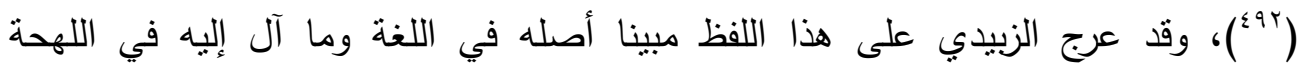

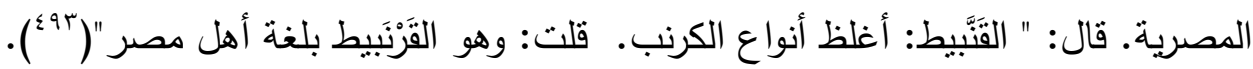

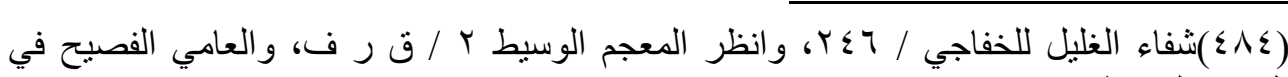

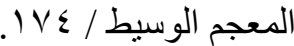

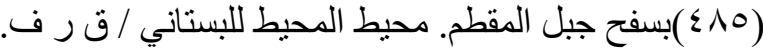

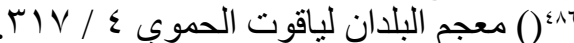

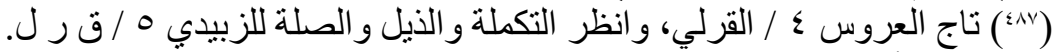
rی

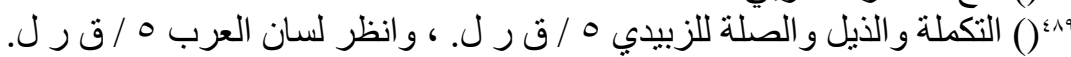

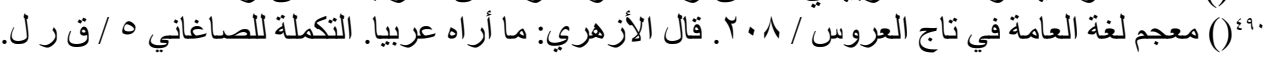

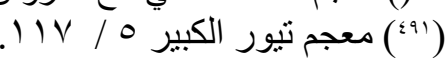

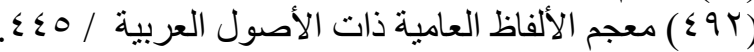

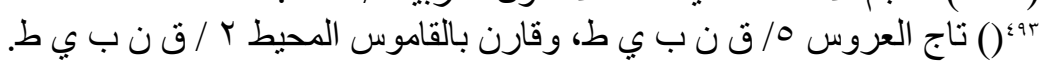




\section{ما نسبه الزبيدي في تاج العروس إلى اللهجة المصرية}

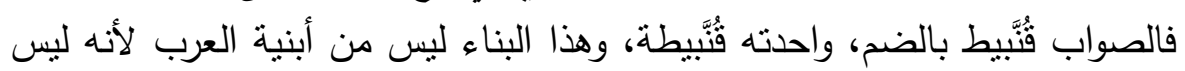

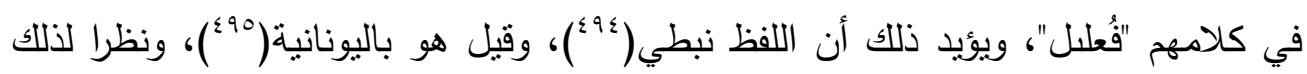

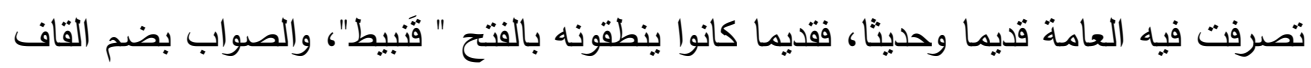

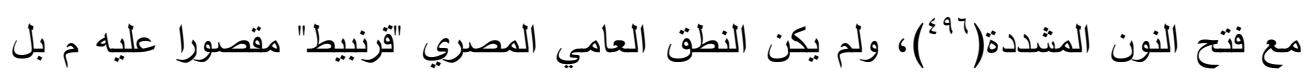
شاركهم فيه قديما أهل صقلية، حيث ذكر ابن مكي الصقلي أنهم يقولون لهذا الضرب من فن لندي

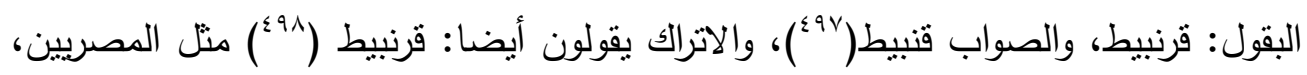
كما أن هذه اللهجة شائعة في أهل الثام أيضا. جاء في المعجم الوسيط:"القنبيط: بقلة زراعية من الفصيلة الصليبية، تطبخ وتؤكل، وتسمي في مصر والثام: القرنبيط"( 99 §).

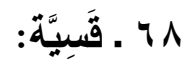

يقال لنوع من الثياب" قَسبيَّة" يجلب من مصر ، منسوب إلى موضع بمصر يقال له

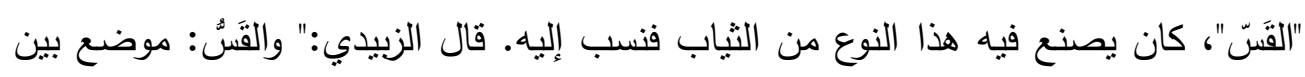
العريش والفَرَما. . . . . ومنه الثياب القسية، وهي ثياب من كتان مخلوط من حرير كانت تجلب من هناك، وقد ورد النهي عن لبسها، وقد يكسر القاف، وهكذا ينطق المحدثون، وأهل مصر يقولونه بالفتح، وقال أبو عبيد: هو القَسِّ، منسوب وإلى بلاد يقال لها: القسِّ، قال وقد

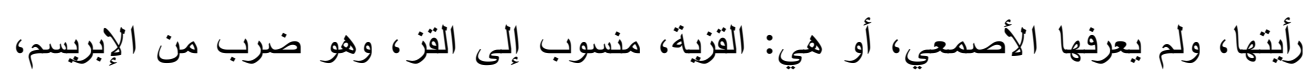

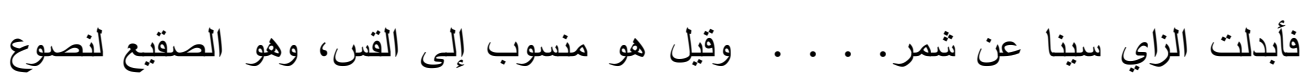

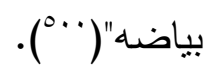

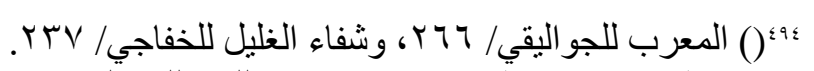

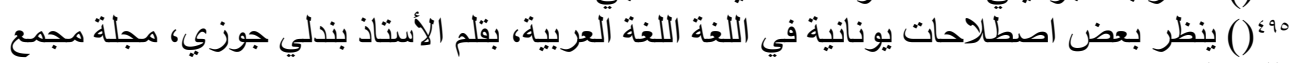

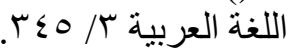

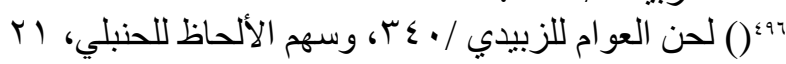

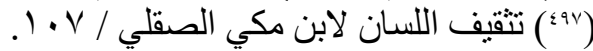

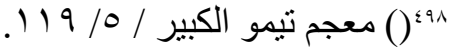

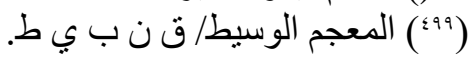

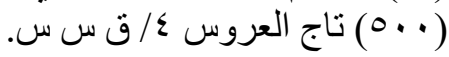


د/ مصطقى عبد الهادي عبد الستار محمد سأست

ومما ذكره الزبيدي يتضح أن القسِّي ثياب من كتان وحرير كانت تصنع في مصر ،

مضلعة مزينة(10) بأمثال الأترج، وفي الحديث عن أبي بردة عن على رضي الله عنه قال:

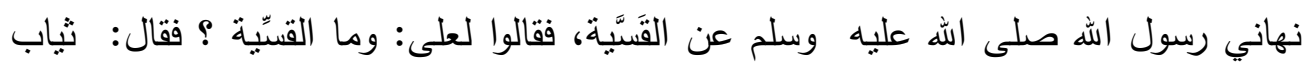
تأتينا من الثام أو من مصر مضلعة فئها أمثال الأترج( ب.0.

وقسا: قرية بمصر ينسب إليها الثياب القّسِيّة، والقَّّ بالفتح والتتديد: اسم موضع

ينسب إلبه الثناب التي نهى النبي صلى الله عليه وسلم عن لبسها، وهي ثياب كان يؤتى بها

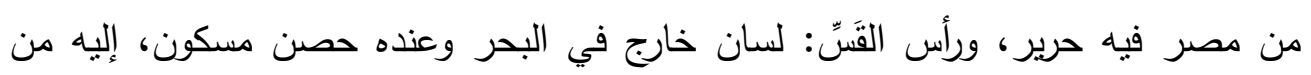

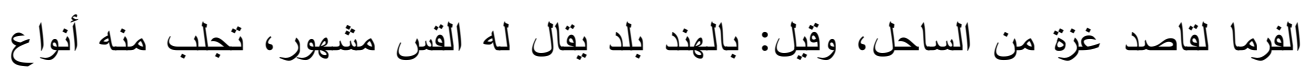

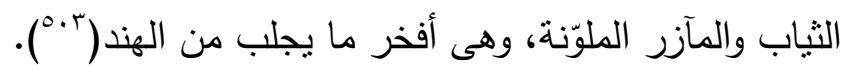

كل ذللك يؤكد ما نص عليه الزبيدي من أن هذه الثياب كانت تجلب من مصر من من من

هذا الموضع الكائن بين العريش والفرما على ساحل البحر تقع فيه هذه القرية التي اشتهرت

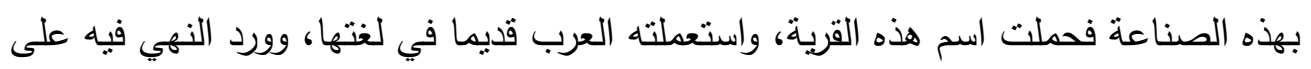

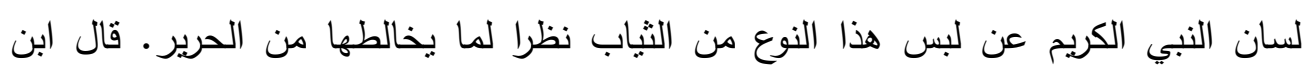

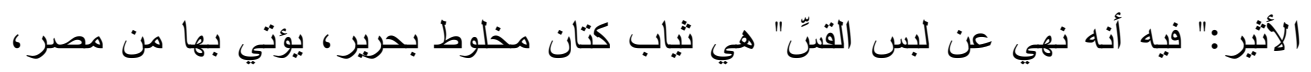

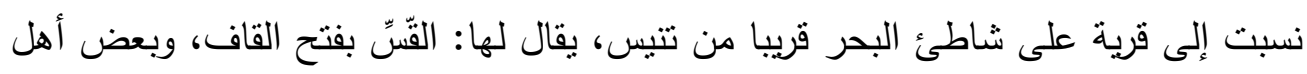

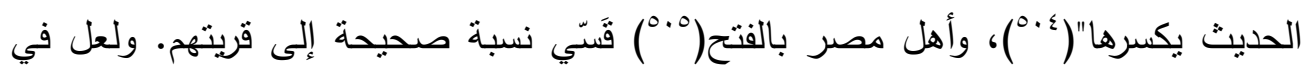
قرب هذه القرية المصرية من بلاد الثام" غزة" ما يفسر لنا شك على رضي الله عنه في نسبتها إلى الثام أو مصر .

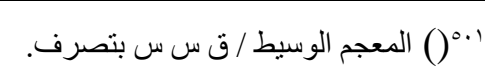

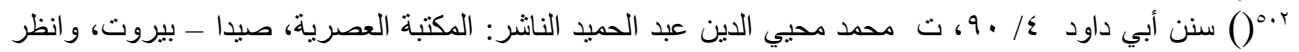

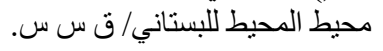

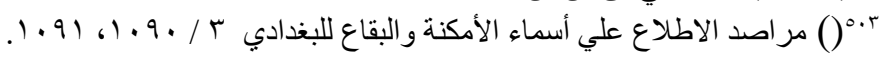

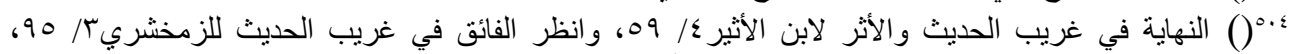

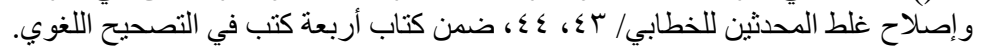

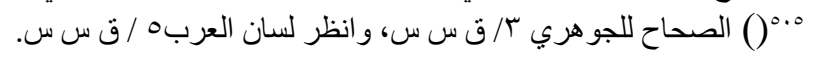


ما نسبه الزبيدي في تاج العروس إلى اللهجة المصرية

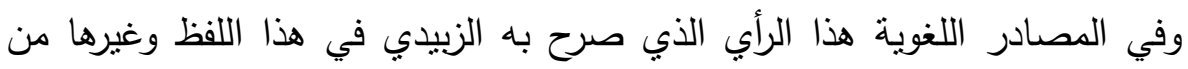

آراء لغوية أخري حكاها الثيخ أيضا، فقد قيل: أصل القَسِّي: القزي بالزاي، منسوب إلى القزي ،

وهو ضرب من الإبريسم، أبدل من الزاي سين، وأنشد لربيعة بن مقروم: ( من الوافر)

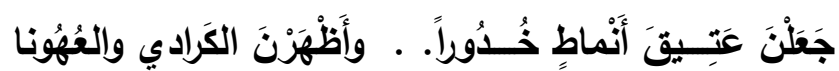

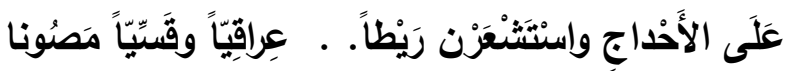

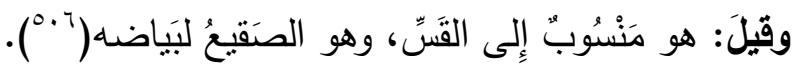

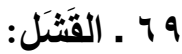

استدرك الزبيدي على الفيروزآبادي المعنى المصري لهذا اللفظ، فقال:" ومما يستدرك

عليه :. . . . والقََّلَ: محركة، يكني به عن الفقر مصرية عامية مبتذلة، وقد قشل

كفرح"( ) (

ونحن نسمع إلى الآن أو نقول: فلان مقشل: بإبدال القاف همزة، أي فقير معدم لا

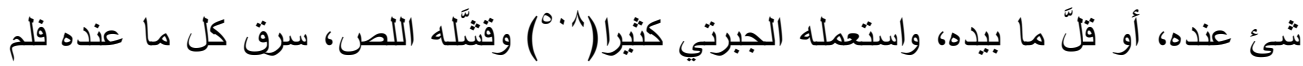
يُقِ له شيئا. ولم أقف على هذا اللفظ بمعناه هذا في معاجمنا القديمة، بل إن مادة هذا اللفظ

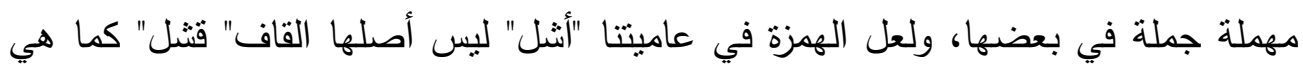
عند الزبيدي، بل ربما كان الأصل فيها الواو" وشل"، فأبدلوا منها الهمزة، وهذا اللون من لن فئن الإبدال معروف في اللغة، فقد قالوا في وحد: أحد، وفي وناة: أناة، وفي وجه: أجه، أبدلوا

الواو همزة، لضعف الواو، عوضا لما يدخلها من الحذف والبدل( 9.9.

ومن معاني مادة" وش ل": وشل وشولا: احتاج وضعف وافتقر وقلَّ غناؤه. ابن

السكيت: سمعت أبا عمرو يقول: الوشول: قلة الغناء والضعف والنقصان، وفلان وانشل ومل وسن

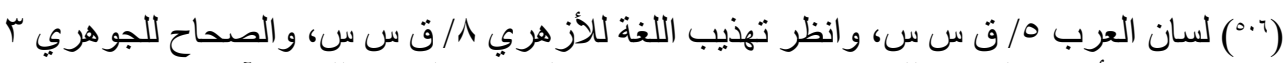

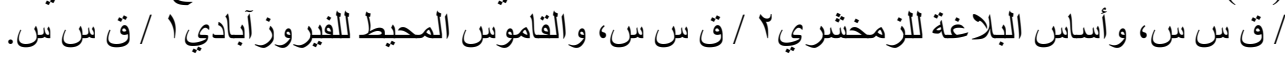

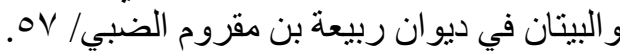

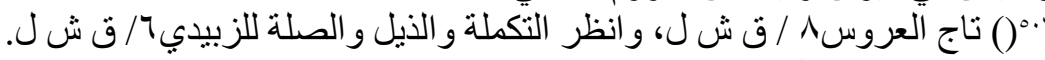

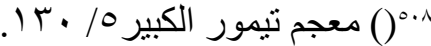

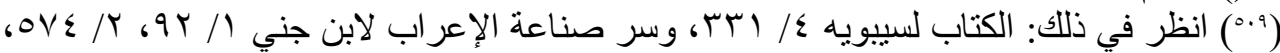

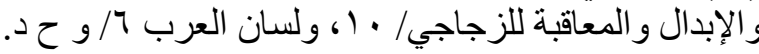

مجلة بحوث كلية الآداب

90 
د/ مصطفى عبد الهادي عبد الستار محمد

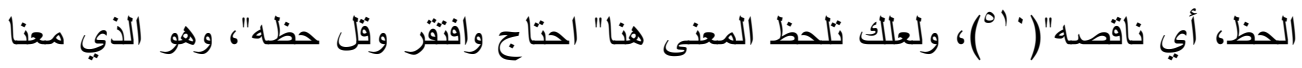
في اللفظ العامي" قثنل " مع صحة الإبدال وإمكان وقوعه بين أنثل ووشل على نحو ما

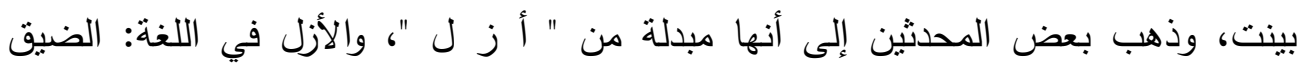
والثدة، يقال: هم في أزل من العيش، أي في شدة، والزاي والثين يتعاقبان، كما في: أزم

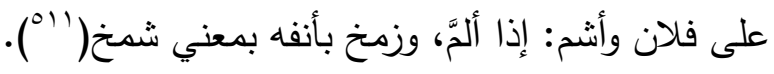

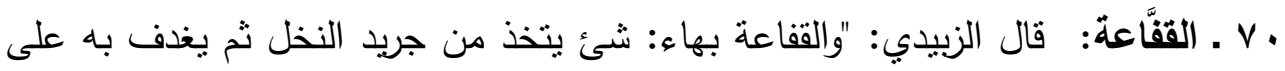
الطير فيصاد. قال ابن دريد: وهي كلمة عراقية، ولا أحسبها عربية. قلت : واستعملها أهل

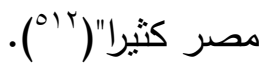

فالقفَّاعة على عهد الزبيدي كان يستعملها المصريون استعمال أهل العراق. قال ابن دريد:" وأما القفاعة التي يسميها أهل العراق، التي يصاد بها الطير فلا أحسبها عربية، وهو شئ يتخذ من جريد النخل، ثم يغدف به على الطير"("(10)، وبعض معجم اللغة لم تتص هلي هذا اللفظ بمعناه المستعمل عند العراقيين والمصريين، ولا حتى المعجم الوسيط( أ())، وفي

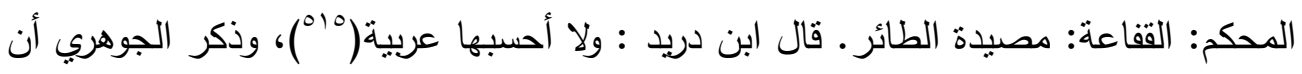

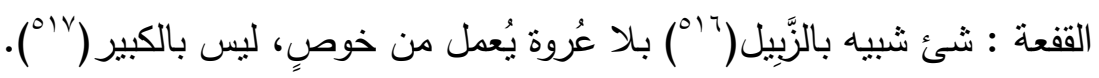
ولعل في تصوير لفظ القعة عند الجوهري فيما سبق له من كلام، والأزهري والزبيدي فيما نقلاه عن أبي عبيد وشمر ما يكثف لنا عن هيئة القفاعة، وكيفية استعمالها عند المصريين والعراقيين على السواء، فقد ذكر أبو عبيد أن القفعة شئ كالزبيل ليس بالكبير

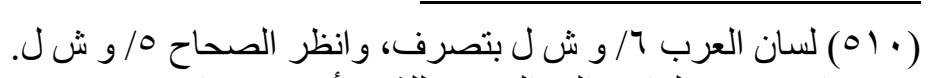

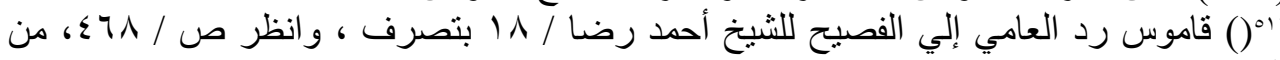

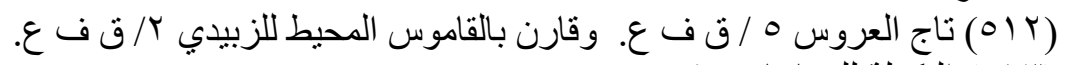

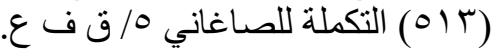

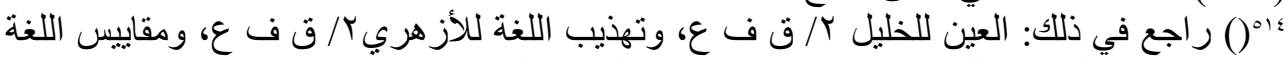

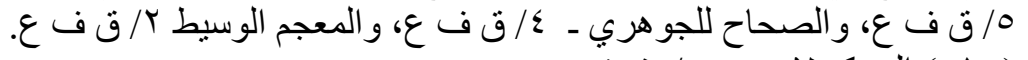

(0) (0) المحكم لابن سيده / ق ف ف ع ع.

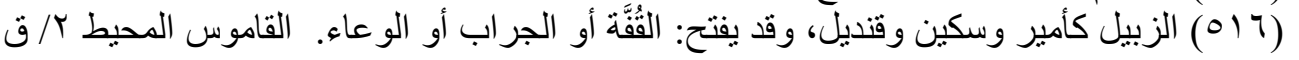

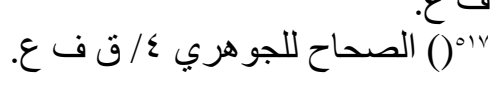


ما نسبه الزبيدي في تاج العروس إلى اللهجة المصرية

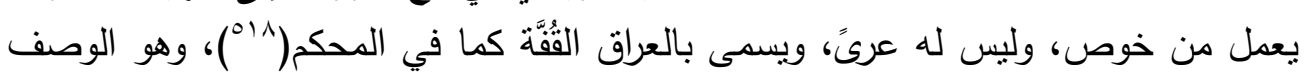
السائد في سائر المعاجم اللغوية، وذكرشمر أن القفعة كالقفة تتخذ، واسعة من الأسفل ضيقة الأعلى، حشوها مكان الحلفاء عراجين تُقق، وظاهرها خوص على عمل سلى سلان الخوص.

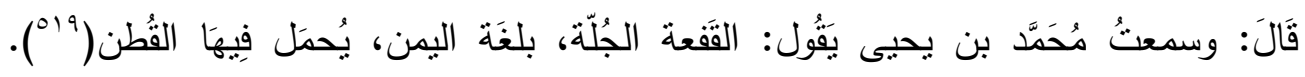
فأضاف استعمال أهل اليمن لهذا اللفظ بمعني قريب لاستعمال المصربين للفظ القفة الآن، فهو عندنا وعاء من خوص ونحوه، يحمل فيه أي شئ ليس القطن فحسب. وبناء على ما سبق فإن القفاعة كانت شبيهة بالقفة على هذه الهيئة والصفة،

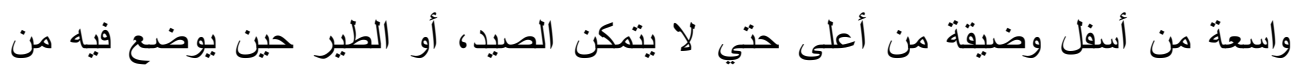
الهرب. وفي معجم تيمور :" قفاعة: لمكان فراخ الدجاج. . . . وهي ققص من الجريد ليس لله

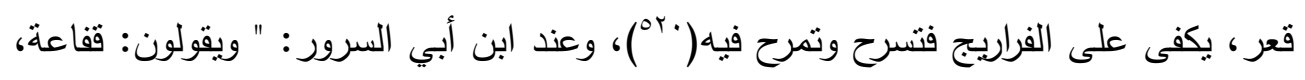

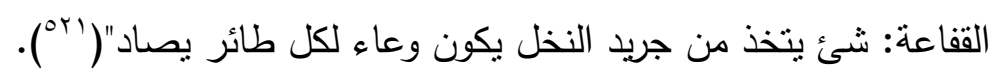
: القمى . VI

القمح نبات عثبي من الفصيلة النجيلية حبه مستطيل مشقوق الوسط أبيض إلى

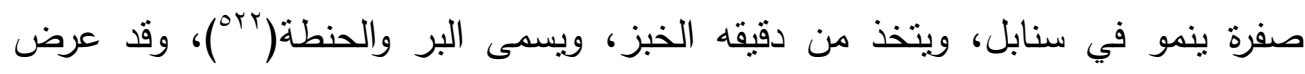
الزبيدي للاختلاف اللهجي فيه. قال الثيخ:" القمح: البر حين يجري الدقيق في السنبل، وقيل من لان الإنضاج إلى الاكتتاز ، وهي لغة شامية، وأهل الحجاز يتكلمون بها، وقد تكرر

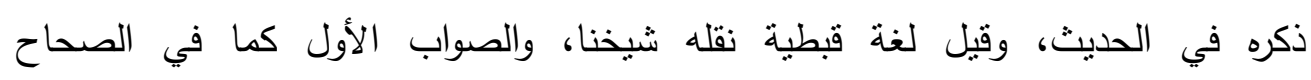

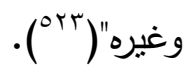

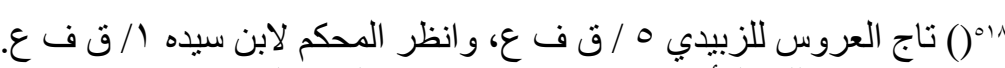

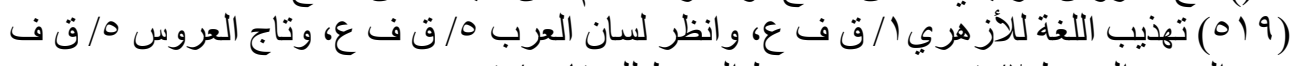

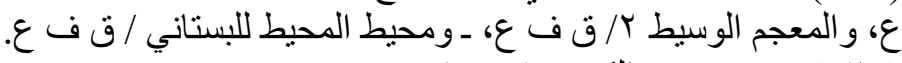

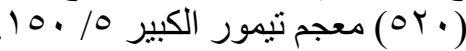

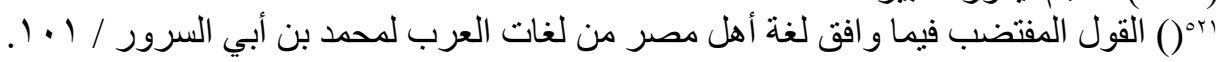

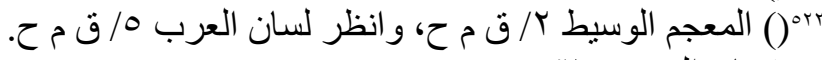

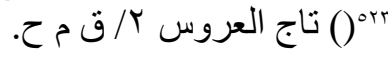




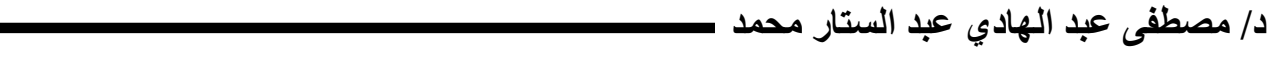

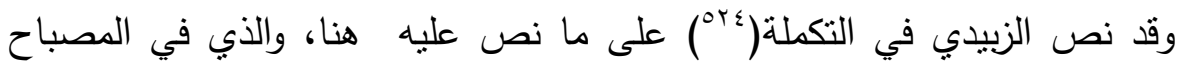
المنير :" القمح:عربي، وهو البروالحنطة والطعام"( وبه)، ولعل الزبيدي عنى بغيرالمصباح لسان

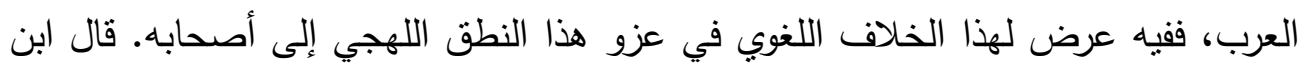
منظور:" والقمح لغة شامية، وأهل الحجاز قد تكلموا بها، وفي الحديث: فرض رسول الله صلي الله عليه وسلم زكاة الفطر صاعا من بر أو صاعا من قمح"( (بك). فعند الفيومي اللفظ عربي، وعند ابن منظور والزبيدي لهجة شامية في الأصل ثم بز نطق بها الحجازيون، أو هي في الأصل لغة قبطية، نطق بها المصريون القدامي، ثم انتقلت بحكم الجوار الجغرافي والتقارب اللغوي قديما إلى الحجاز والثام، وهذا التجاور الجغرافي يفرض علينا أن ننظر إلى هذه الأقاليم على أنها وحدة لغوية واحدة، فاللفظ أثر من آثار العربية العمورية ( قمح. .وMmh) والعربية العمورية خليط من العربية الكنعانية والعربية الأجاريتية(1) مما يرجح عروبة اللفظ، ولا يحول ذلك دون القول بأنه وجد في لسان أهل الثام موطن العرب الكنعانيين والأجاريت على حد سواء.

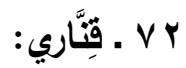

مما استدركه الثيخ الزبيدي على صاحب القاموس لفظ" القناري" بمدلوله العامي المصري. قال:" وما يستدرك عليه . . . . والقناري بالكسر والتشديد ضرب من الشعير يشبه

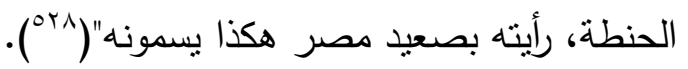

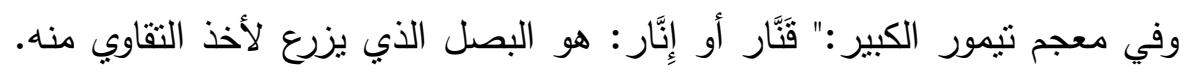

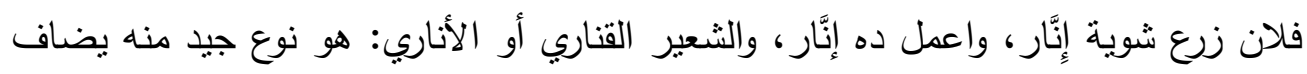

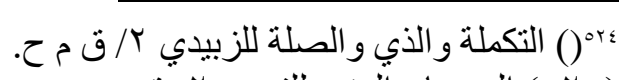

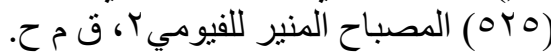

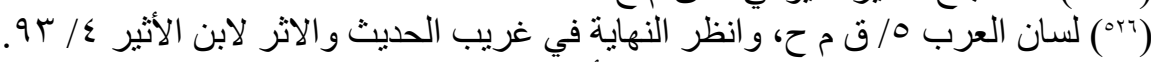

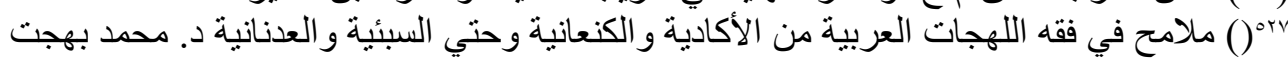

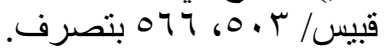

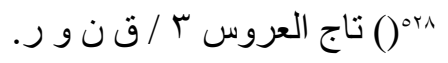


ما نسبه الزبيدي في تاج العروس إلى اللهجة المصرية

في الغالب على الذرة لعمل الخبز، وحبته قصيرة سمينة، ويسمي بالهراوي لأن أهل هِرِّيَّة

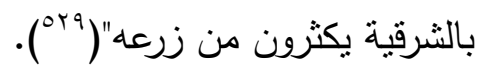

(القيراط: VT

يقول الزبيدي: " القيراط: يختلف وزنه أب القيراط بحسب اختلاف البلاد، فبمكة

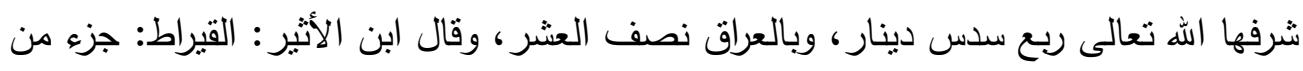
أجزاء الدينار، وهو نصف عشره في أكثر البلاد، وأهل الثام يجعلونه جزءا من أربعة وبنا وعشرين. قلت: واتفق أهل مصر أنهم يمسحون أرضهم بقصبة طولها خمسة أذرع بالنجاري،

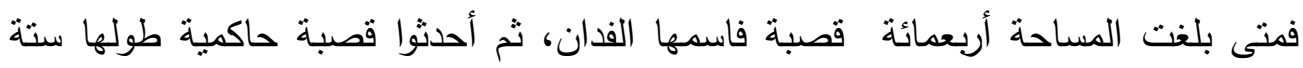
أذرع وربع سدس بالذراع المصري، وجعلو القصبتين في الضرب بدانق، والثلاثة إلى الأربعة، والخمسة إلى السبعة بحبة، والثمانية نصف القيراط والعشر بحبتين، وهكذا إلى المائة تنقص قصبتين وبعض قصبة بربع فدان. كذا وجدته في بعض الكتب المؤلفة في فن المساحة، وفي حديث أبي ذر ستفتحون أرضا يذكر فيها القيراط فاستوصوا بأهلها خبرا فإن لهم ذمة ورحما، ونها،

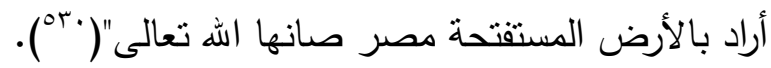
وعليه فإن لفظ القيراط من الألفاظ التي كانت شائعة في القطر المصري قديما وما زالت إلى الآن تجري على ألسنة المصريين، وقد فصل الزبيدي القول فيه بما تحته من معان مختلفة ترجع إلى اختلاف الاستعمال اللغوي في الوزن والقياس تبعا لاختلاف بيئاته اللغوية، والمراحل الزمنية التي مر بها، فاستعمال المصريين للقيراط مخالف لاستعمال العراقيين، وأهل مكة، وأهل الثنام على ما هو بيِّن من كلام الزبيدي السابق، فهو عندهم معيار للوزن يقدر بربع سدس دينار وعند المكيين، ونصف عشره في أكثر البلاد بما فيها أهل العراق، خلافا

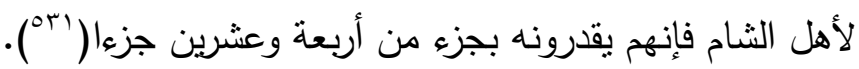

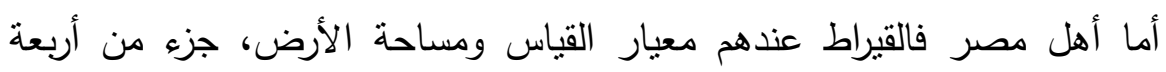
وعشرين جزءا، ولا يخفى أن كلا الاستعمالين للفظ في الوزن والقياس ينطق به المصريون

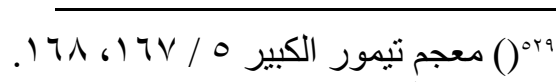

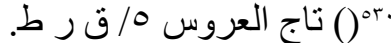

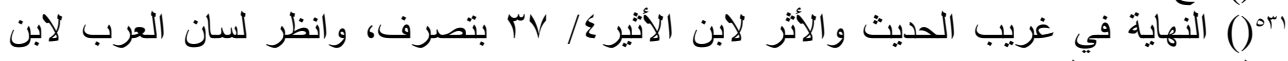

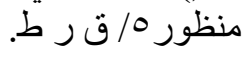




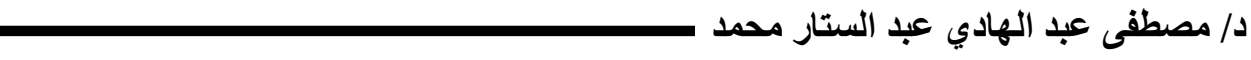
حتى اليوم، ففي المعجم الوسيط: القيراط: معيار في الوزن وفي القياس، اختلفت مقاديره باختلاف الأزمنة، وهو اليوم في الوزن أربع قحات، وفي وزن الذهب خاصة ثلاث قمحات.

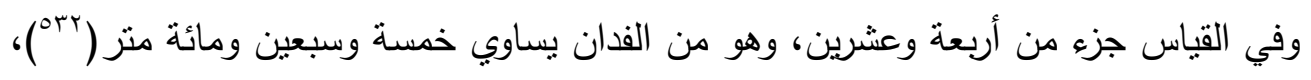
وربما استعمل المولدون القيراط بمعني عرض الإصبع في المساحة، وجعلوه دستورا في

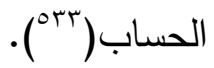

والقيراط من الألفاظ القديمة التي لهج بها المصريون، وقد شرفها النبي صلى الله عليه وسلم فنطق بها قال:" ستقتحون أرضا يذكر فيها القيراط فاستوصوا بأهلها خيرا فإن لها

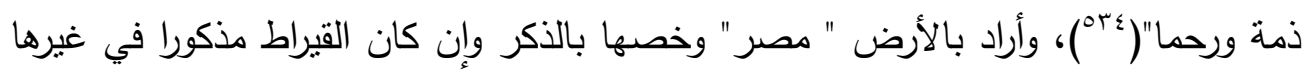

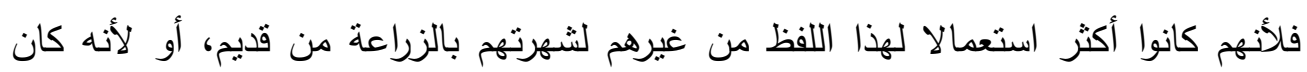

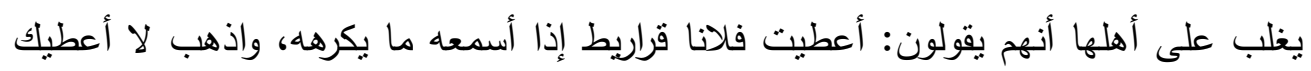

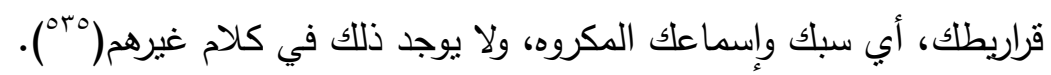

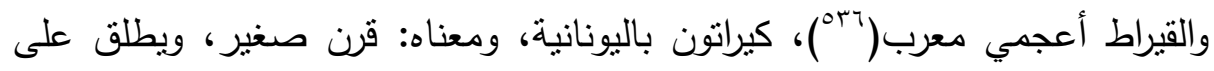

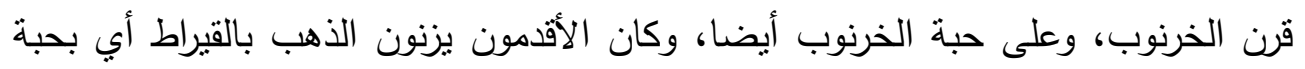
الخرنوب("rv) وذهب ابن دريد إلى أن أصل القيراط من قولهم: قرَّط عليه إذا أعطاه قليلا

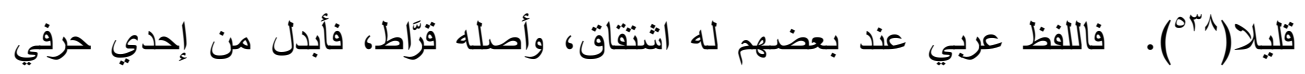
تضعيفه ياء، وجمعوه على قراريط، كما قالوا: دينار ، وجمعوه على دنانير ("rqه).

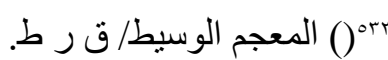

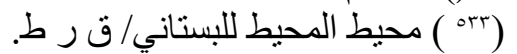

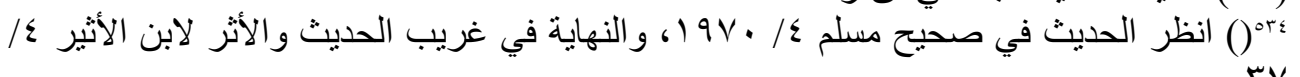

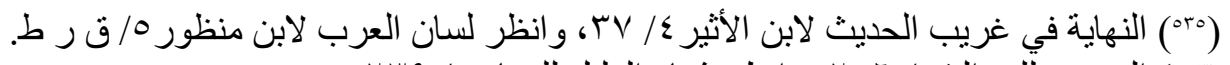

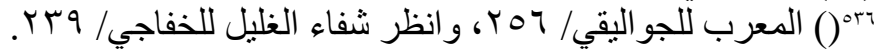

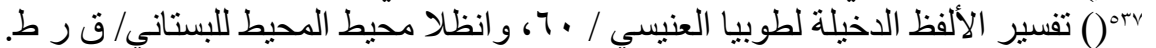

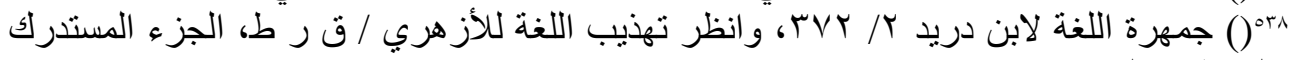
علي طبعة التهذيب.

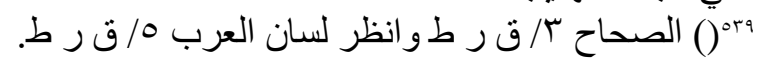


ما نسبه الزبيدي في تاج العروس إلى اللهجة المصرية

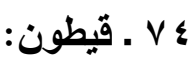

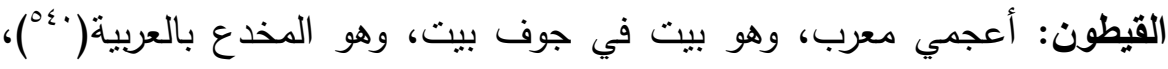

وقع في شعر قديم أنثده المبرد في الكامل لعبدالرحمن بن حسان، وقيل لدعبل الجمحي :

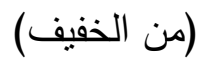

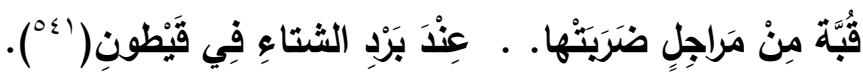

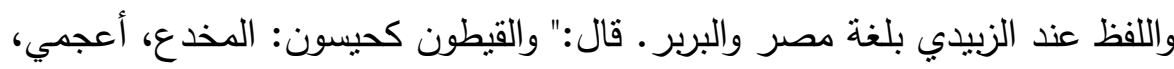

وقيل بلغة مصر وبربر، وقال ابن بري هو بيت في بيت، وقال شيخنا هو البيت الثنتوي

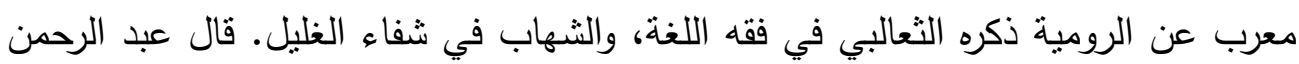

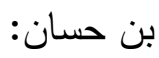

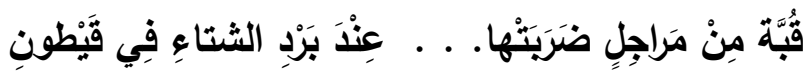
قلت ويروى لأبي دهبل قاله في رملة بنت معاوية وأوله:

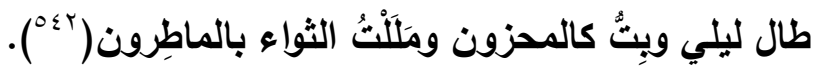

فاللفظ مختلف في عزوه، فمنهم من قال إنه من الرومية، ومنهم من قال أنه من

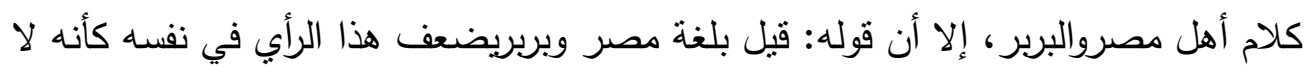
يميل إليه، وليس ذللك برأيه الذي عهدناه منه من قطع اللفظ في النسبة إلى ناطقيه من

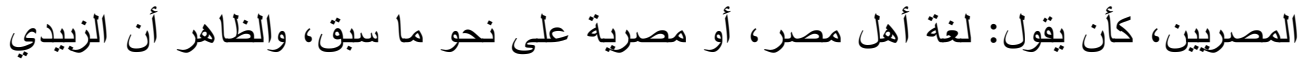

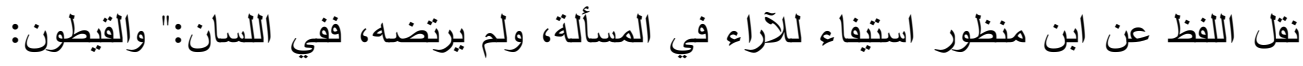

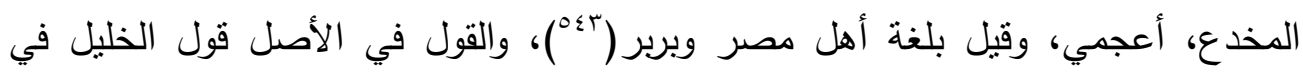

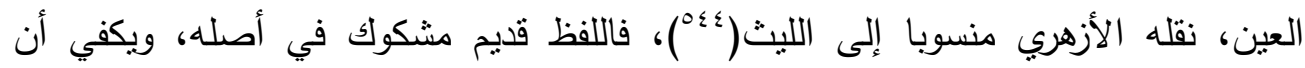

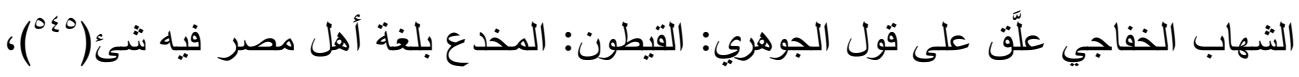

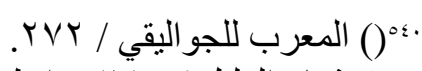

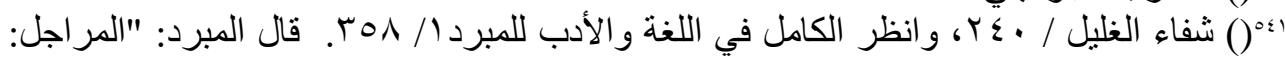

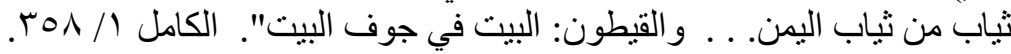

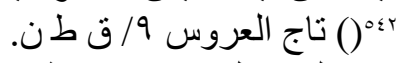

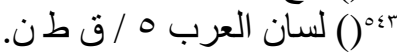

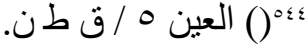

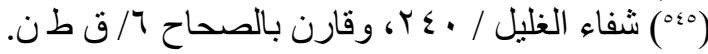




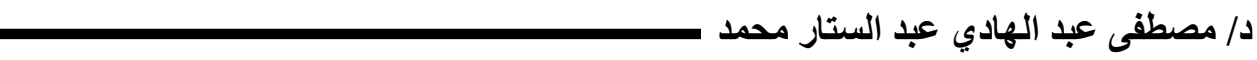

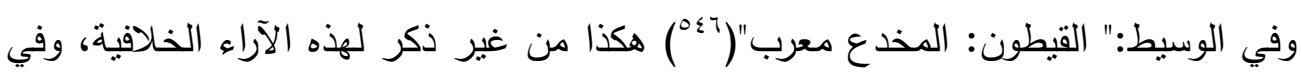

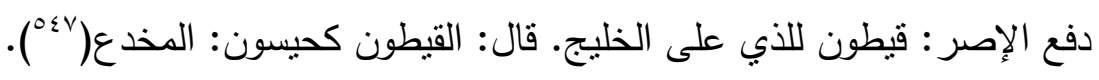

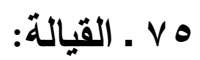
قال الزبيدي: "ومما يستدرك عليه . أي على صاحب القاموس .. . . . . والقيَّلة:

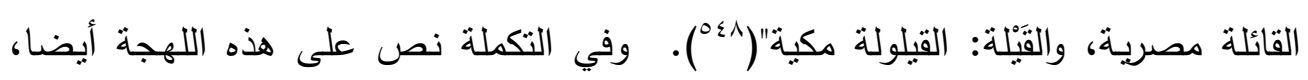

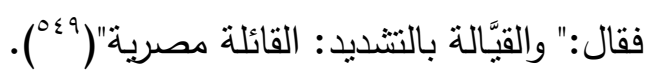
أي أن القيالة في معني القائلة لهجة مصرية، وهي إلى الآن ما زالت معروفة ينطق

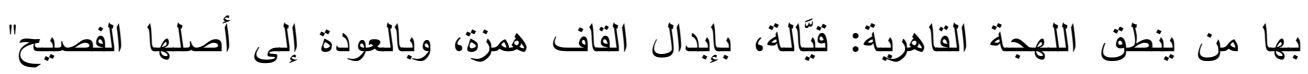
القائلة" نجد ما يلي: القائلة: نوم نصف النهار (100)، والقائلة، الظهيرة، يقال: أنانا عند القائلة،

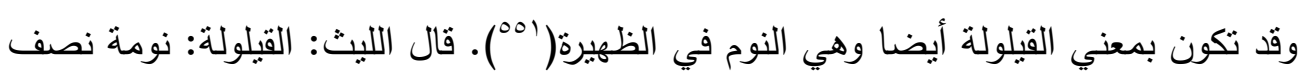
النهار، وهي القائلة(roo)، والذي ذهب إليه الأزهري هو أن القيلولة عند العرب، والمقيل: الاستراحة نصف النهار إذا اشتد الحر، وإن لم يكن مع ذلك نوم، والدليل على ذلك أن الجنة النه

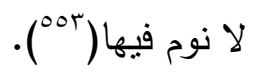

وتأسيسا على ما سبق يتبين لنا أن القيَّالة تطلق على القائلة، أب أنهم يعنون وقت القائلة عند اثتداد الحر، وما يستتبعه من نوم فيها أو استراحة، ونقول في عاميتتا أيضا لئنا

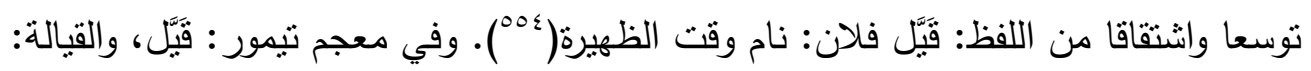

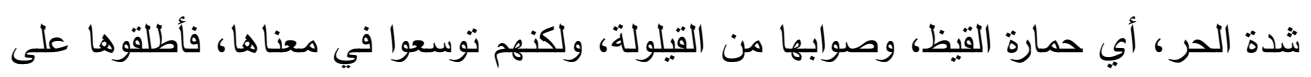

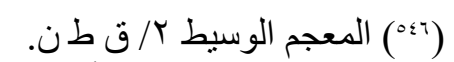

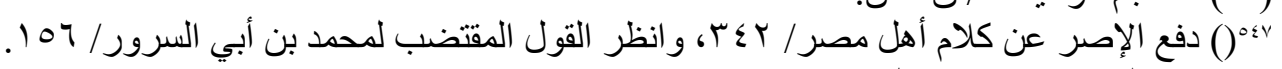

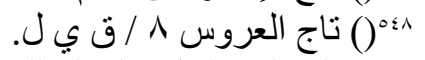

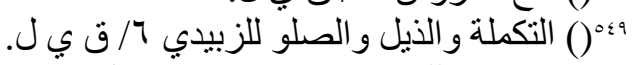

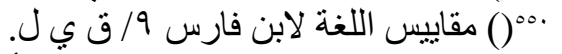

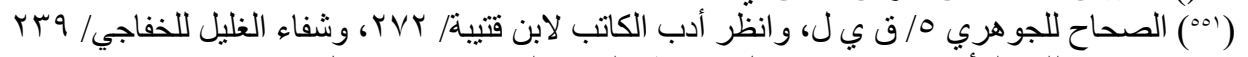

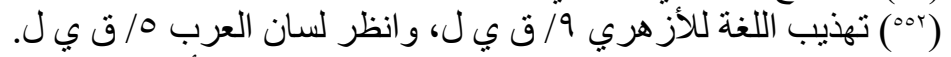

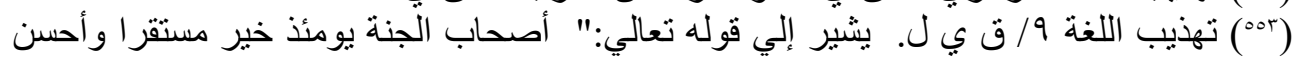

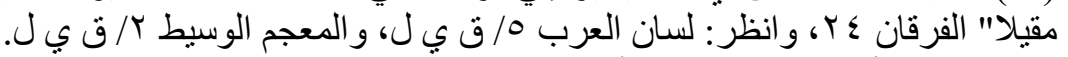

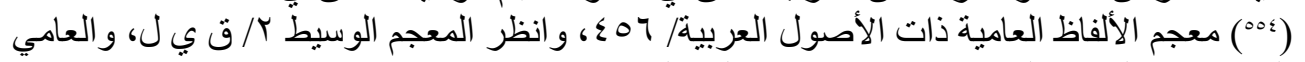

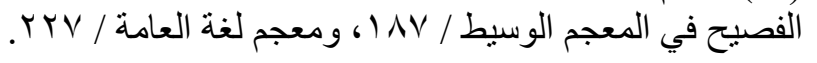

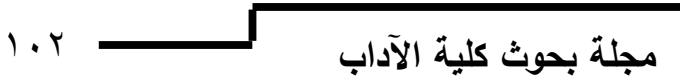




\section{ما نسبه الزبيدي في تاج العروس إلى اللهجة المصرية}

شدة الحر لتلازم الظرف مع الفعل الحاصل فيه أعني أن هذا الوقت مظنة النوم والاستراحة

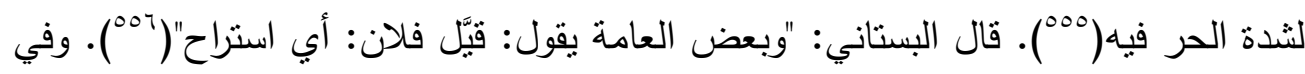

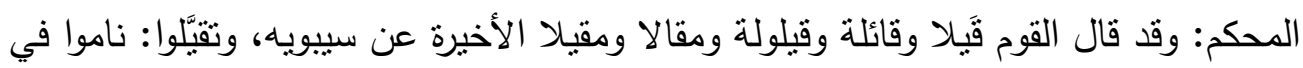

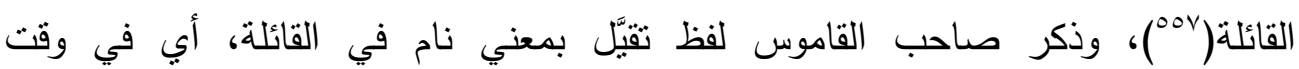
الظهيرة(1001). (الكُبَّة:

في عاميتتا المصرية يقال: ابتلي الله فلانا بكُبَّة، أي: ابتلاه الله بشدة أو سقوط في مهلك( (009)، ونسمع من يدعو على أحد بالكُبَّة يعني بالمرض الثديد المرادف مثنا للطاعون والمؤدي إلى الهالك، وقد وقف الزبيدي على هذا اللفظ مبينا اختلاف اللهجات العربية فيه،

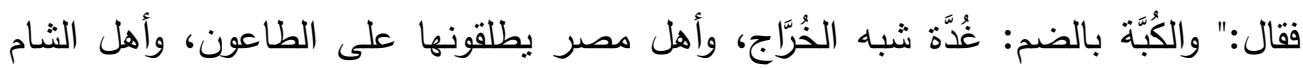

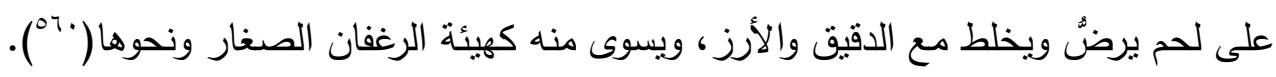
ونجد هذين المعنين المولدين في المعجم الوسيط، بيد أنه لم يشر إلى الفرق اللهجي في العزو إلى أصحابهها، كما عند الزبيدي، ففيه:" الكُبّة: الكَبَّة، والتقل، يقال ألقى عليه لهيه

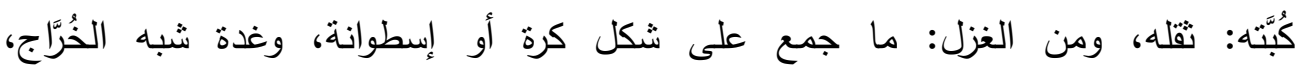
والطاعون(مولد)، ولحم يدق ويضاف إلبه جريش القمح قبل أن ينضج ويُكَبَّب وبطهى.

وهذ اللفظ في معاجم اللغة تحته أكثر من معنى، فالكَبَّة وبضم: الدفعة في القتال، والجري، والحملة في الحرب، والزحام، وإفلات الخيل، والصدمة بين الجبلين، ومن الثتاء:

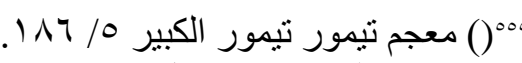

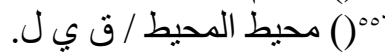

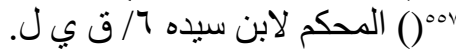

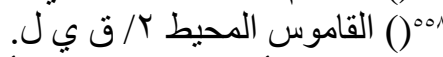

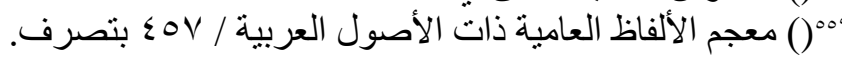

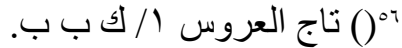

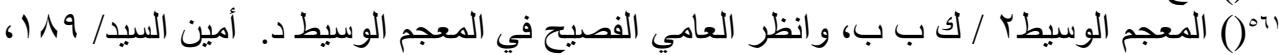
ومحيط المحيط للبستاني/ ك ب ب بـ بـ بـ 
د/ مصطقى عبد الهادي عبد الستار محمد موندي

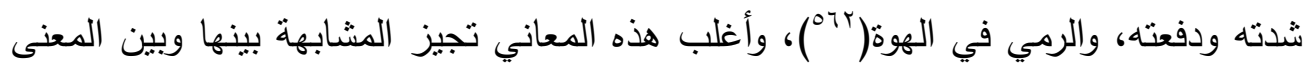

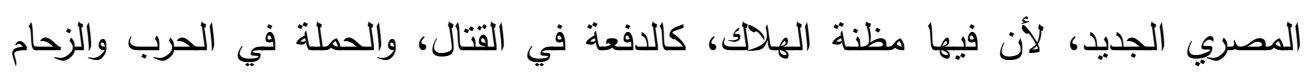
وشدة الثتاء ودفعته والرمي في الهوة. وفي مقاييس اللغة ما هو قريب مما نحن بصدده "

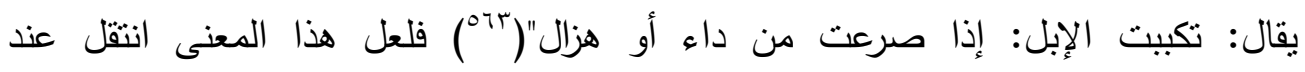

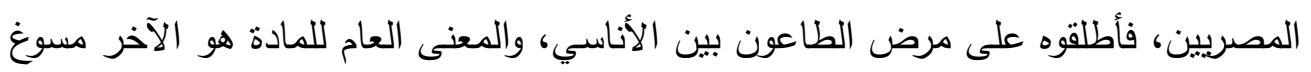

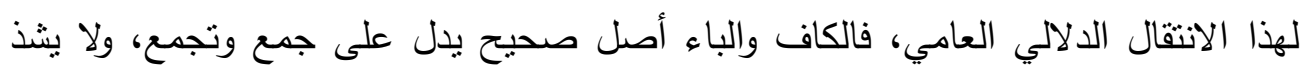

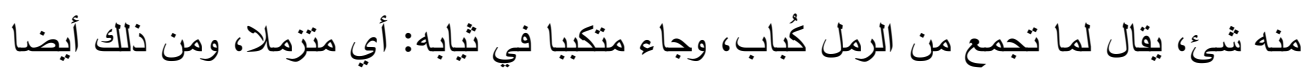

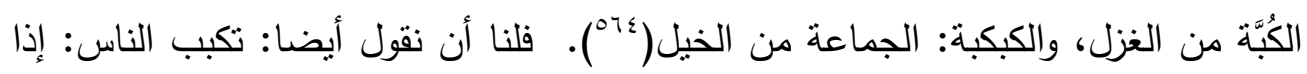
صرعوا من الطاعون، فكأنهم جمعوا أو تجمعوا في مهلكهم، وفي بعض مصادر من العامية المصرية واللفظ لتيمور :" والكبة: هي الخروج الذي يكون من الطاعون. يقولون في كلامهم:

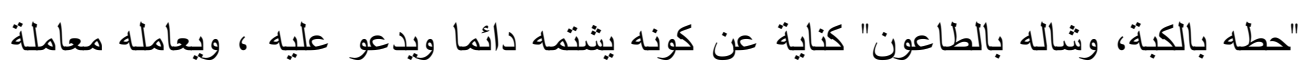

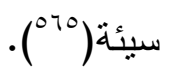

وأما المعنى الآخرالذي أورده الزبيدي عن أهل الثام، فالكبة: طعام من لحم يدق

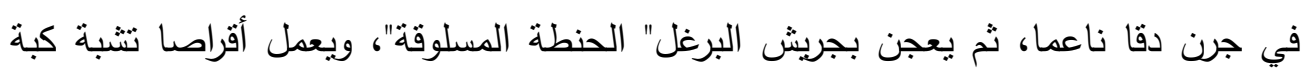

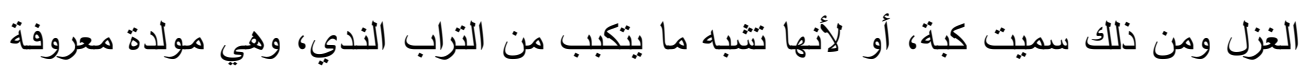

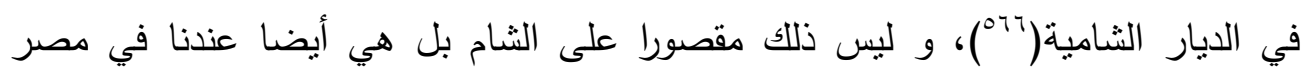

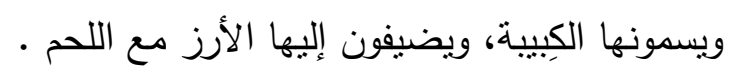

بهن() القاموس المحيط // /ك ب ب، و انظر الصحاح للجوهري // ك ب ب، ولسان العرب 0/ ك ب

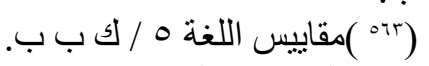

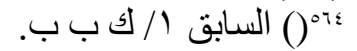

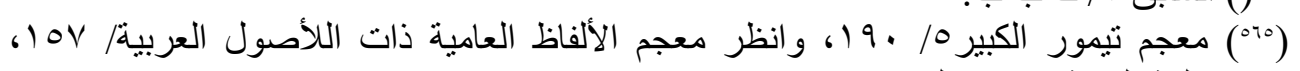

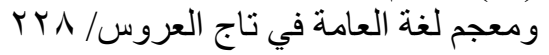

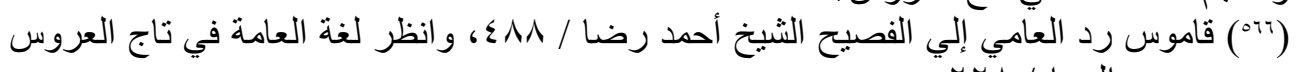

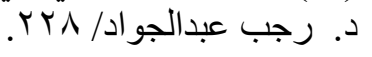

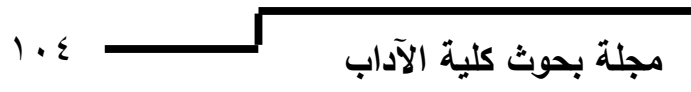


ما نسبه الزبيدي في تاج العروس إلى اللهجة المصرية

ـ VV

ورد لفظ الكَرْنَبَة عند الزبيدي في معجمه بمعني المغرفة، ونص على أن ذللك من

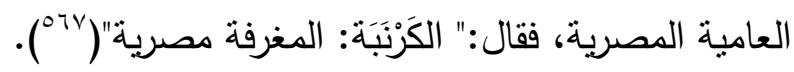

ولم أقف على شئ فيها إلا أنها وردت بصيغة الجمع في كتابات شهاب الدين

النوبري، ففي نهاية الأرب:". . . . ويجعل تحت كل أُبلوجة من تلك الأباليج قادوس يقطر فيه

ما يتخلص من رقيق ذلك المحلب . وهو العسل القطر. ثم يخدمها الرجال بالكرانيب مرة بعد

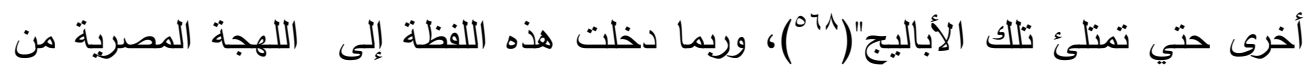

اللغة اليونانية، فالكرنيب في

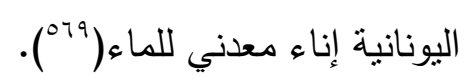

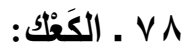

الكعك: تعريب كاتك(•)؛، وهو خبز يعمل من الدقيق والسكر والسمن، ويسوى

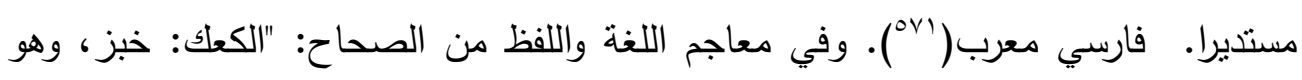

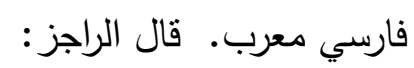

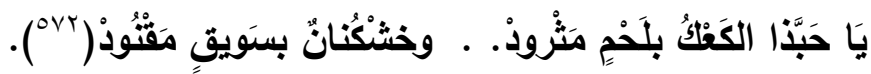

هذا وقد عرض الزبيدي لهذا النوع من الخبز بلفظه عرضا مفصسا ليس بعده زيادة

لمستزيد. فقال:" الكعلك: خبز معروف، قال الجوهري: فارسي معرب، وأنشد للراجز :

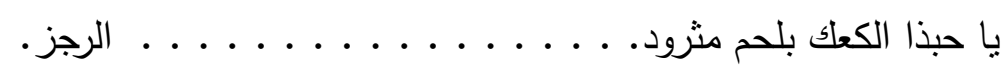

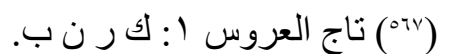

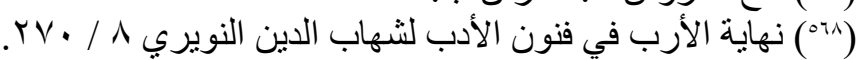

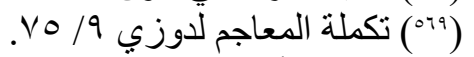

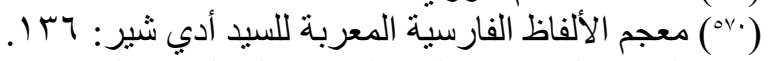

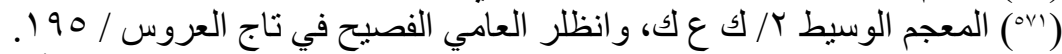

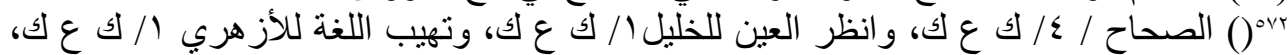

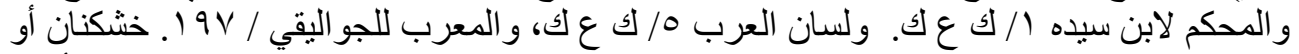

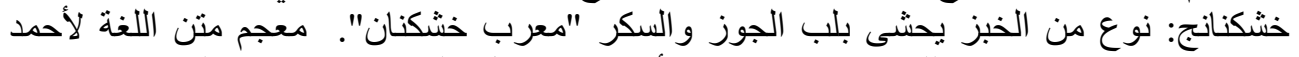

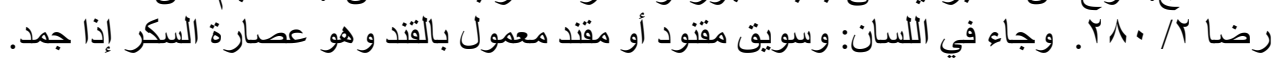


د/ مصطقى عبد الهادي عبد الستار محمد

وقال الصاغاني: هو تعريب كالك، وقال الليث: أظنه معربا، وقال غبره: هو الخبز اليابس، ويطلق الآن الكعك على ما يصنع من الخبز كالحلقة أجوف، وأجوده ما جلب من الثام

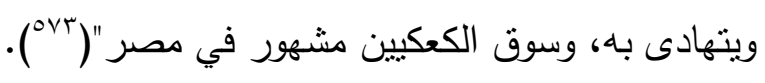

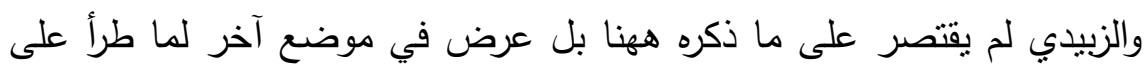

هذا اللفظ من تطور صوتي ناشئ عن تعاقب الهاء مع العين على ألسنة بعض العامة من

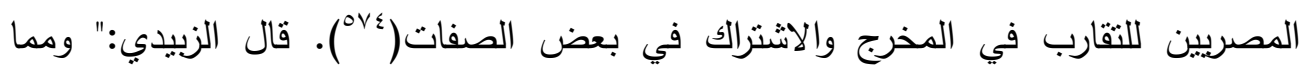

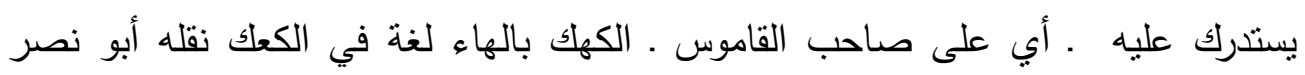

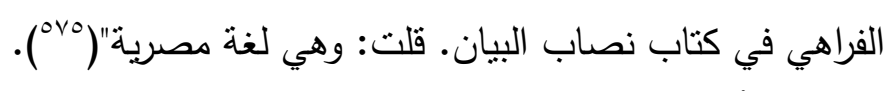

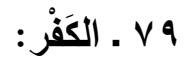

ذكر الزبيدي لفظ الكَفْر بما آل إلبه من استعمال عامي عند المصريين. قال:". . .

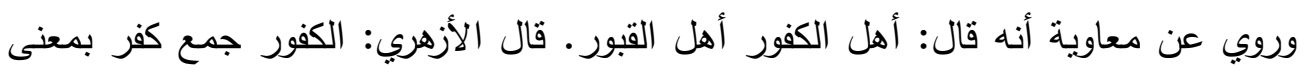

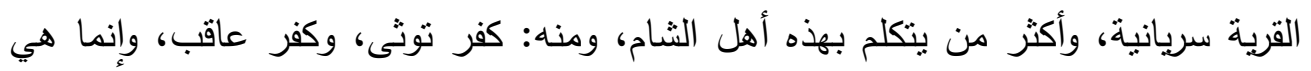

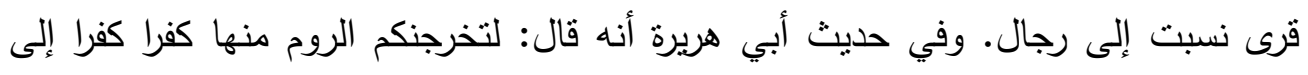

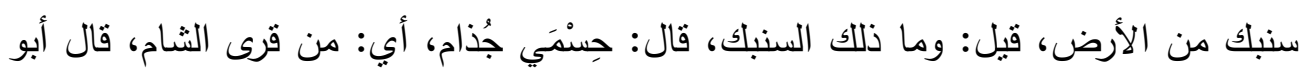
عبيد كفرا كفرا، أي قرية قرية، وقال الأزهري في قول معاوية: يعني بالكفور القرى النائية عن

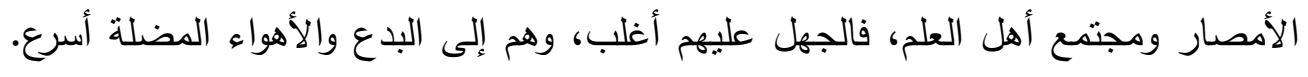
يقول: إنهم بمنزلة الموتى لا يشاهدون الأمصار والجمع والجماعات وما أثبهها، وفي حديث آخر لا تسكن الكفور فإن ساكن الكفور كساكن القبور. قال الحربي: الكفور: ما بعد من الأرض عند الناس فلا يمر به أحد، وأهل الكفورعند أهل المدن، كالأموات عند الأحياء، فكأنهم في القبور • قلت: وكذلك الكفور بمصر هي القرى النائية في أصل العرف القديم، وأما

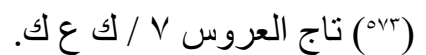

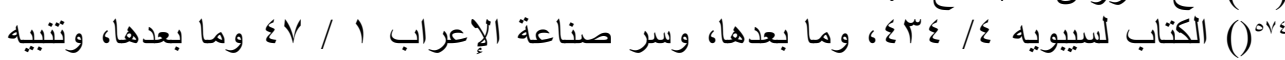

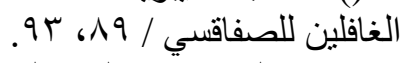

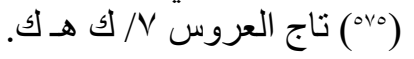

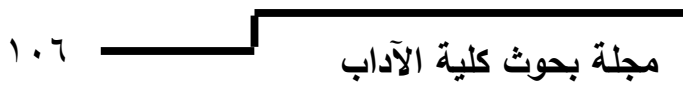


ما نسبه الزبيدي في تاج العروس إلى اللهجة المصرية

الآن فيطلقون الكفر على كل قرية صغيرة بجنب قرية كبيرة، فيقولون القرية الفلانية وكفرها،

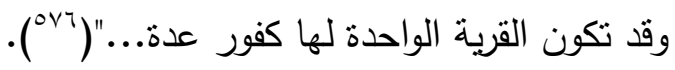

وبناء على ما صرح به الزبيدي فإن لفظ "الكفر" مما شاع على ألسنة العامة من آن آنه

المصريين، وتعني القرية، وقد كثف الزبيدي عن المدلول الأصلي للفظ وما آل إليه في في العامية المصرية على عهذه، وساق من الأحاديث والآثار ما يكثف عن هذا اللفظ اللهجي وتجذره في العربية، فالكفر استعمل أول ما استعمل لدلالة على الأماكن البعيدة النائية عن المدن والحضر ، وما يستتبعه ذلك من خمول وقلة تحضر لعدم اتصالها بالمدن، وقد جاءت الثواهد التي نص عليها الزبيدي مدللة على هذا المعنى، ففي حديث أبي هريرة: لتخرجنكم

الروم منها كفرا كفرا إلى سنبك من الأرض، قيل وما ذلك السنبك قال: حسمي جذام( ومن ذلك حديث معاوية:" أهل الكفور أهل القبور" أي هم في منزلة الموتى لا لاهي

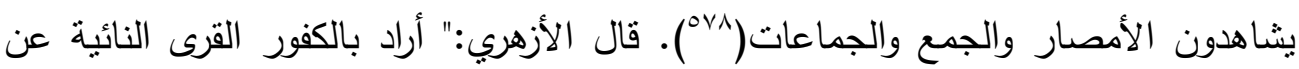
الأمصار ومجتمع أهل العلم والمسلمين، فالجهل عليهم أغلب، وهم إلى البدع والأهواء

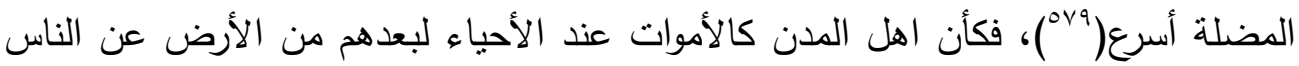

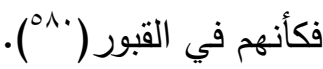

وقد كانت الكفور في العرف قديما هكذا على هذا النحو من الوصف، ثم أضحت" الآن" على عهد الزبيدي تطلق على القرية الصغيرة(1هـ) بجوار القرية الكبيرة، هذا الكفر تابع لها وعلى صلة بها اجتماعيا وإداريا لقربه منها، كما هو المعهود الآن في الإقليم الذي نعيش

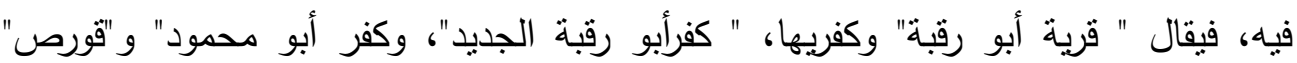

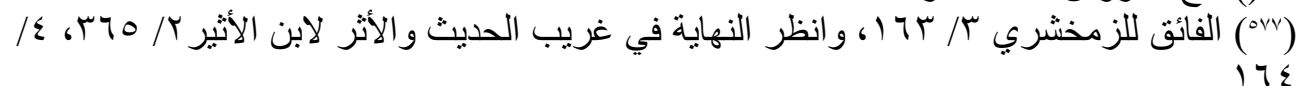

$$
\text { (0) }
$$

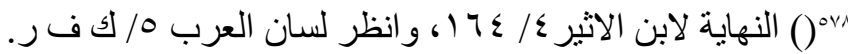

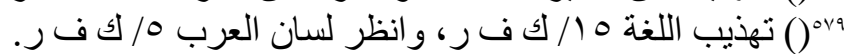

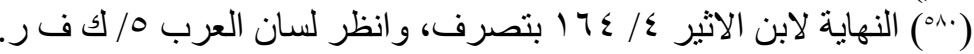

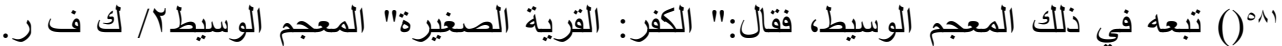

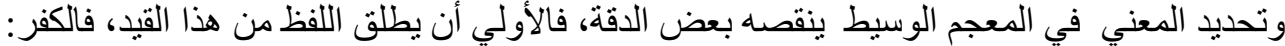

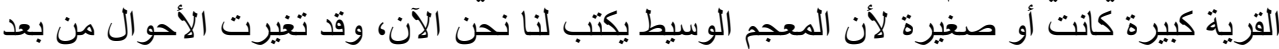
الزبيدي و أضحت قري كثبرة كبيرة أو مدنا آهلة. 
د/ مصطقى عبد الهادي عبد الستار محمد

وكفرها " كفر قورص" إلى غير ذللك، ثم أضحى أيضا علما على بعض المدن المدن الكبرى، مثل كفر الدوار، وكفر الزيات، وكفر الثيخ، وكفر سعد.

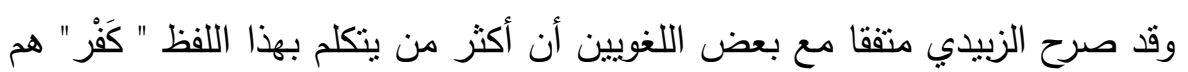
أهل الثام، ومنه قولهم: كفر توثى، وكفر طاب، وكفر تعقاب، وكفريَّا، وكفر عاقب، وكفر

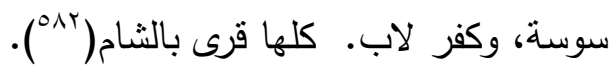

ويشاركهم في كثرة استعمال هذا اللفظ المصريون، وقد تكون القرية الواحدة عندهم

مشتملة على كفور عدة. قال الزبيدي:" فمن المشاهير الكفور الثاسعة، وهي كورة مستقلة مشتملة على عدة قرى، وكفر دمنا وكفر سعدون وكفر نطرويس، وكفر باويط وكفر

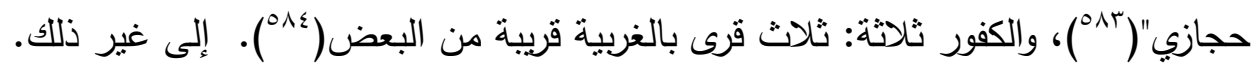

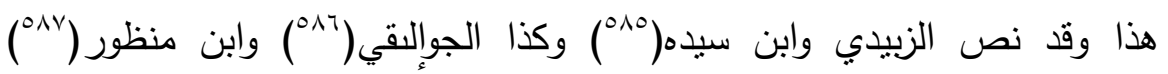
والخفاجي(م^ه) على أن اللفظ ليس بعربي إنما عربته العربية من السريانية، وقال ابن دريد:"

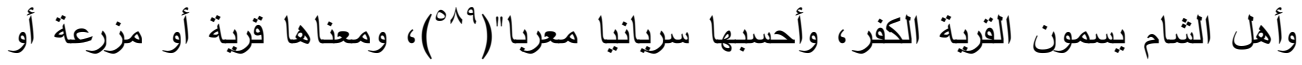
حقل أو هي من" كفَرَ بالعبرانية، حكي هذا الرأي البستاني، والشيخ رشيد عطية في

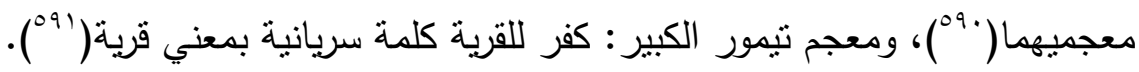
وأيما كان أصل هذا اللفظ فهو يدور في فلك المشترك السامي إن قلنا من السريانية أو من العبرية، فلا غرو أنه في الأصل أثر في اللغات الثلاثة ( العربية والسريانية، والعبرية)

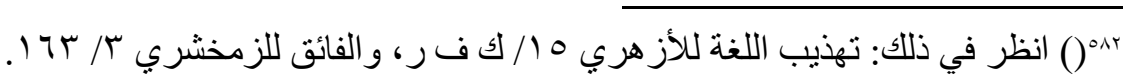

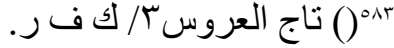

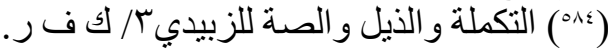

$$
\begin{aligned}
& \text { ) }
\end{aligned}
$$

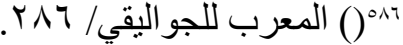

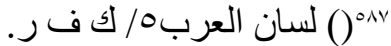

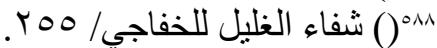

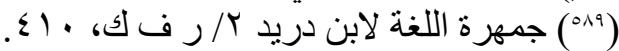

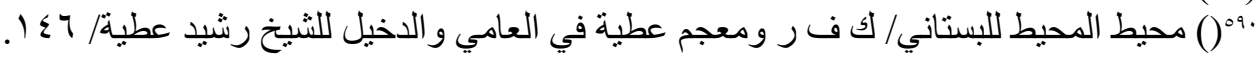

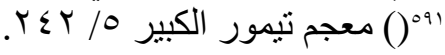

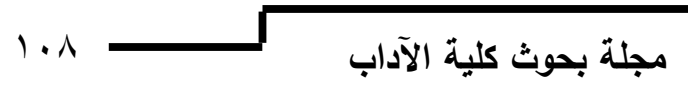


ما نسبه الزبيدي في تاج العروس إلى اللهجة المصرية

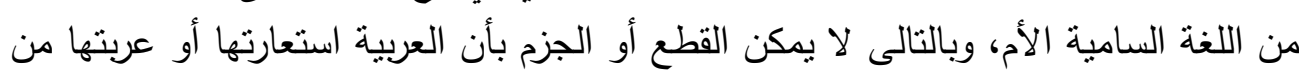

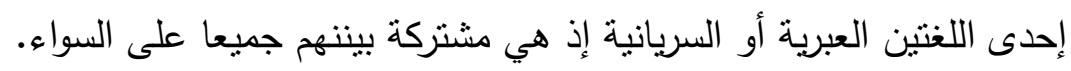

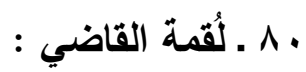

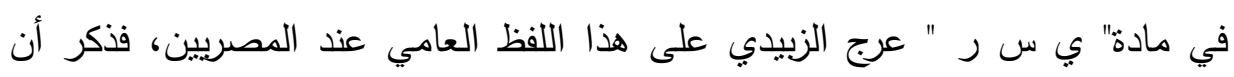

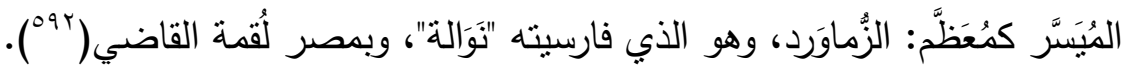

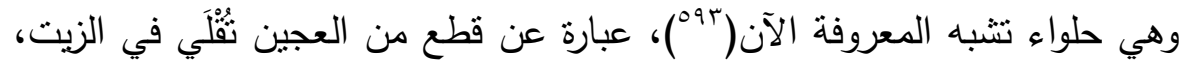

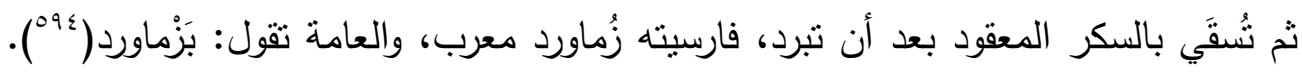

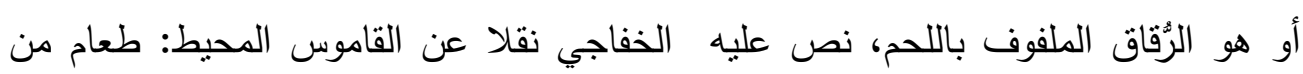

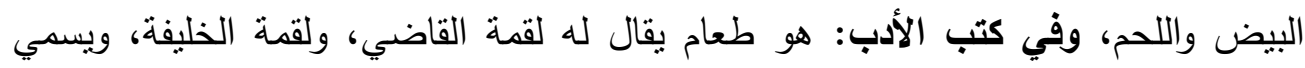

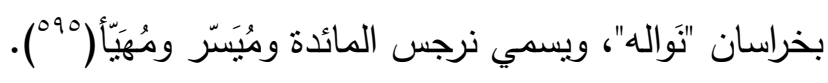

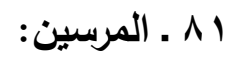

المرسين لفظ أطلقه المصريون على شجر الآس، صرح بذلك الزبيدي في استدراكه

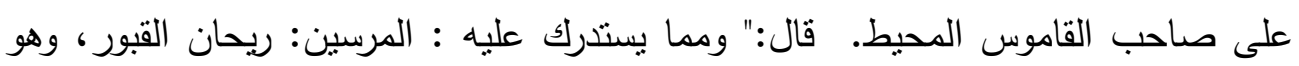
الآس لغة مصرية"(")

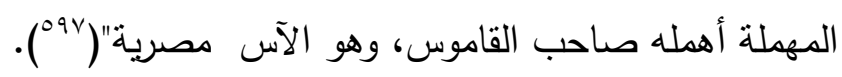
والآس: شجر دائم الخضرة بيض الورق أبيض الزهر أو ورديه عطري وثماره لبية سود

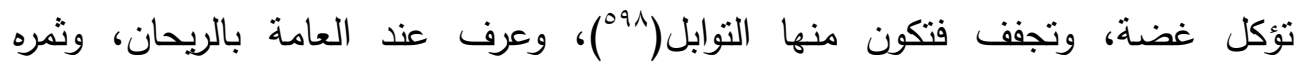

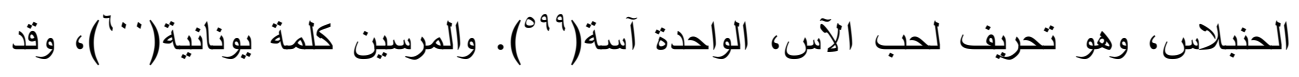

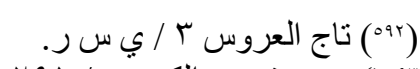

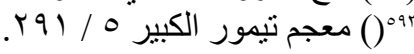

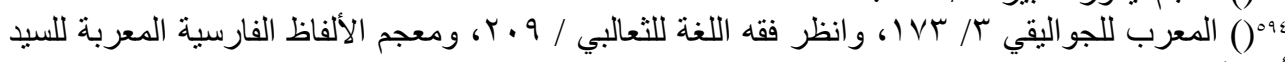

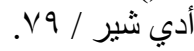

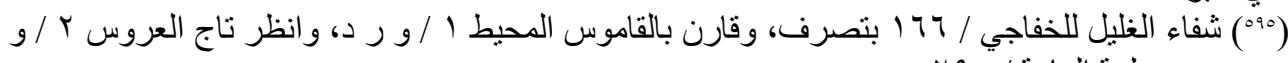

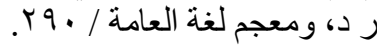

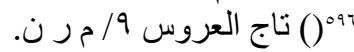

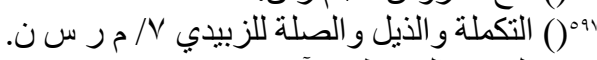

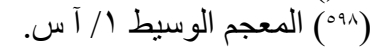

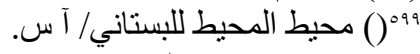

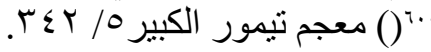


د/ مصطفى عبد الهادي عبد الستار محمد

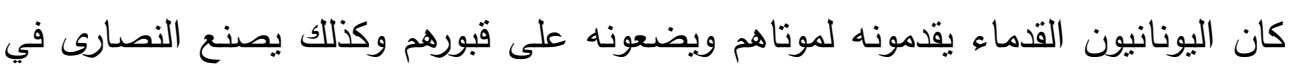

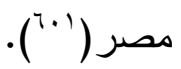

ז A ـ مِصر:

مِصنر البلد العربي الإسلامي المعروف ـ حرسها الله وصانها من كل مكروه ـ تتنطقه

العامة من أهلها بفتح الميم. قال الزبيدي:" ومصر بالكسر فيها فلا ينوهم فيها غيره، كما قال

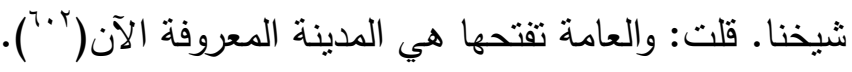

ولا أظن أن الزبيدي قصد بالعامة غير أهلها، وفي التكملة قرر الزبيدي هذا، فذكر

أن مصر بالكسر على الأشهر، والعامة تفتحه، هي المدينة المشهورة، وهكذا سماها الله تعالى لهي

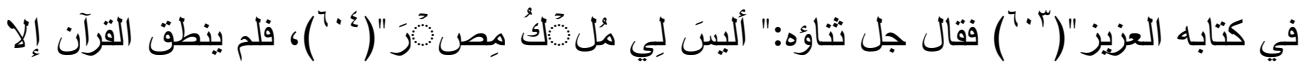
بالكسر، وإنك لتلحظ التطور الحاصل فيها على ألسنة المصريين، فاللفظ له دلالتان عند العامة، فمصر تعني القطر أو الدولة، ومصر تعني: القاهرة عاصمة الدولة، على ما هو معروف عند عامة المصريين إذا قصدوا السفر أو الذهاب إلى القاهرة قالوا: سافرنا أو ذهبنا

إلى مصر ، يقصدون القاهرة.

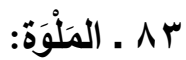

المَلْوَة إحدى المكاييل التي يستخدمها المصريون في معاملاتهم، وقد لاحظ الزبيدي أن هذا الاستعمال كان شائعا في اللهجة المصرية، فقال مستدركا على صاحب القاموس:

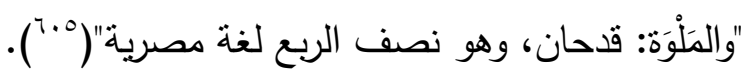

وفي بعض المعاجم اللغوية تعريف بهذا المكيال، ففي المعجم الوسبط: المَلْوَة: مكيال

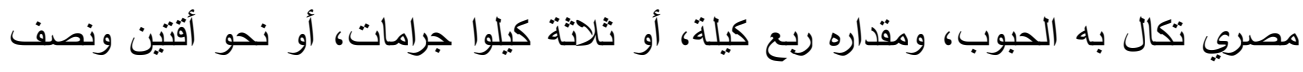

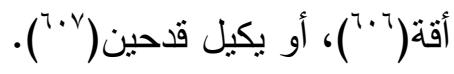

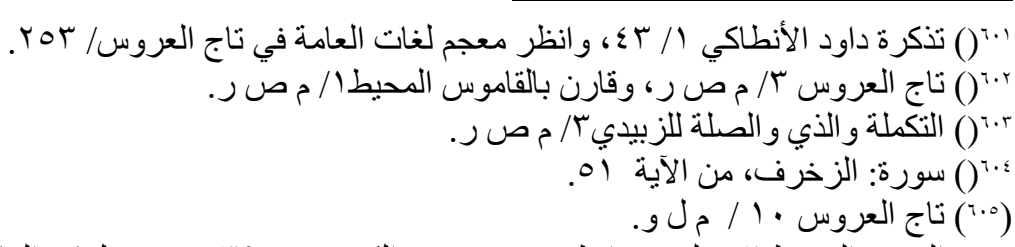

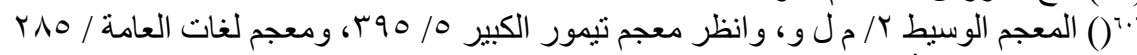

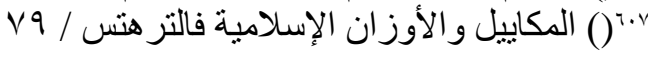


ما نسبه الزبيدي في تاج العروس إلى اللهجة المصرية

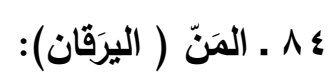

عرض الزبيدي للفظ المَنّ بمعناه العامي المصري من خلال حديثه عن لفظ اليرَقان، حيث نص على أن اليرَقان لغة في "الأرقان"، وقال في بيانه:" اليرقان: آفة للزرع تصيبه عنديه

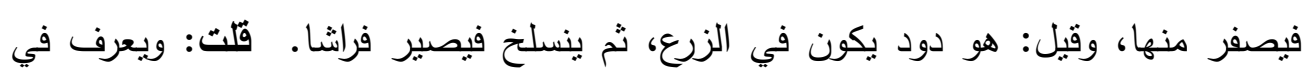

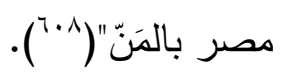

وفي لسان العرب(9 +7) ما نص عليه الزبيدي في اليرقان من أنه آفة تصيب الزرع،

أو دود يكون فيه ثم ينسلخ فيكون فراشا، وقد حدد المعجم الوسيط هذا اللفظ بمفهومه الواضح عند كل من الزبيدي وابن منظور، ولم يعرج على اللفظ العامي المصري هنا، فذكر أن اليرقان مرض فسيولوجي يصيب النبات فيصفر، أو أنه أحد أطوارالنمو في بعض الحضي الحيوان، كالحشرات والقشريات وغيرها، يخرج من البيضة، وقد يتحول إلى حيوان يافع مباشرة، كما في لي

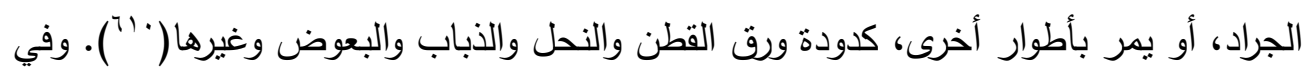

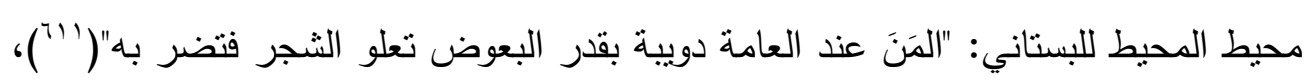

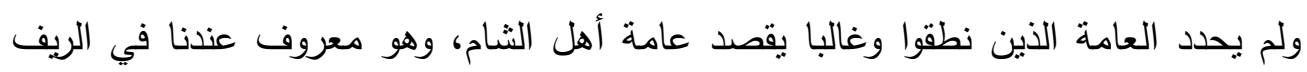
المصري، وينطقه عامة الناس والفلاحون: المِنّ بكسر الميم.

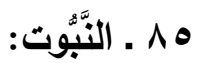

في عاميتتا نقول: النَّبُوت لعصا تؤخذ من فروع الأشجار، ونقول فلان أخذ حقه بالنَّبُوت كناية عن أخذه الحق بالقوة(r') )، ولقد استدرك الثيخ الزبيدي هذا اللفظ بمعناه

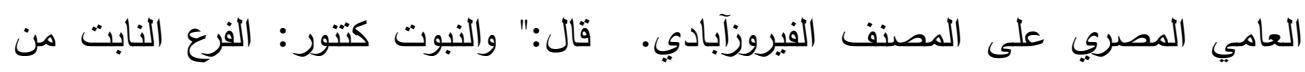

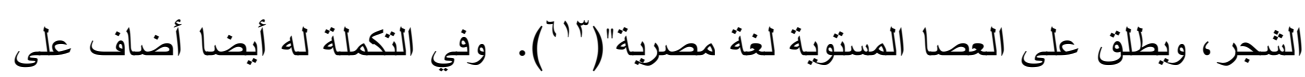

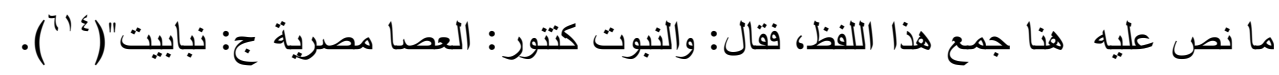

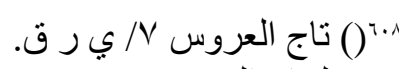

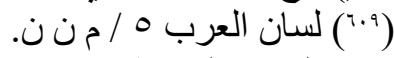

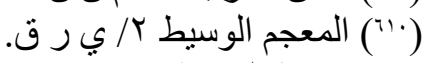

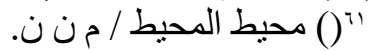

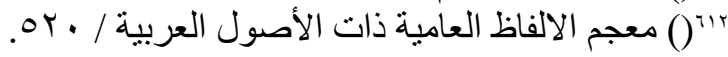

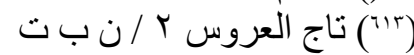

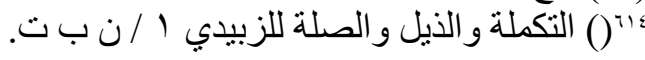


د/ مصطقى عبد الهادي عبد الستار محمد

و اعتمد المعجم الوسيط على ما نص عليه الزبيدي، فذكر أن النبوت الفرع من

الثجر، وبطلق على العصا الطويلة المستوية لغة مصرية، كما في التاج جمعها: نبابيت(10")، فزاد في الوصف الطويلة على ما هو معروف عندنا في شكلها وهيئتها من

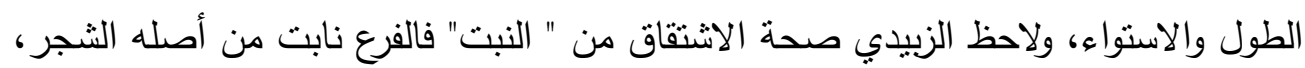
مما يدل على نوافق النطق العامي مع أصل اللفظ في العربية، ومن المحدثين من اعتمد على هذا الفهم، فأرجع اللفظ إلى أصله العربي، فلفظ النبوت عربي الأصل فيه: نابت، ثم اهن صغرته العامة على نبُوت، كقولهم: قدور في قادر، وفطوم في فاطمة، واستأنس على هذا الأصل بما في القاموس المحيط، ففيه: النابت: النشء الصغير، والفرع الناشئ في الثجرة(17) - (7) (17).

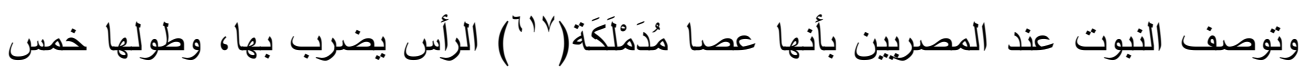
إلى ست أقدام طولا، ضخمة ومجهزة بحلقة حديد تمنعها من الانشطار (1/1).

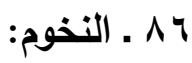

قال الزبيدي: "النَّخُوم كصبور كورة بمصر ، وقال باقوت: هي كلمة قبطية، اسم لمدينة

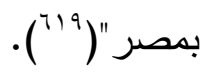

وفي معجم البلدان: " النخوم بالفتح كلمة قبطية: اسم لمدينة بمصر"("r.")، ولعلها بخوم التي سبق ذكرها في" ب خ م " فوقع فيها التصحيف عند الزبيدي نقلا عن ياقوت.

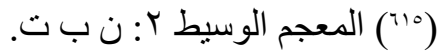


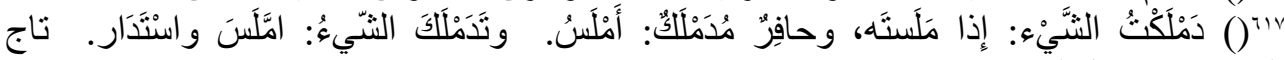

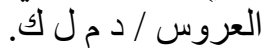

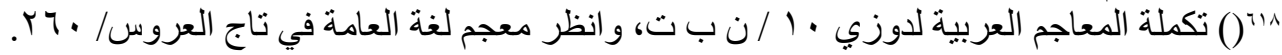

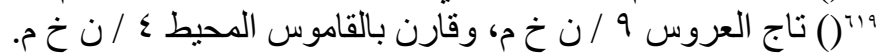

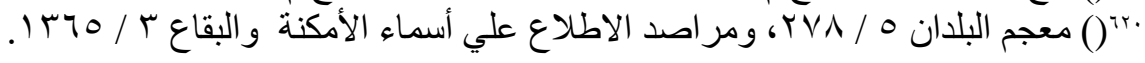


ما نسبه الزبيدي في تاج العروس إلى اللهجة المصرية

AV

صرح الزبيدي بعامية هذا اللفظ في اللهجة المصرية، فالهالوك: سُم الفأر، وأيضا

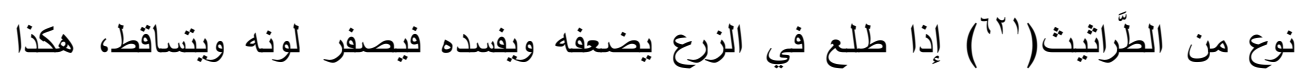

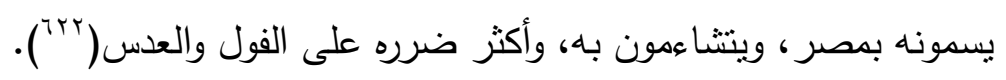
فالهالوك وإن كان من الألفاظ الثائعة في اللهجة المصرية إلى الآن لا يخفى على

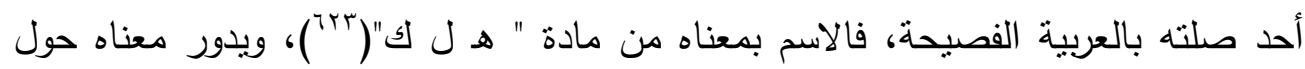

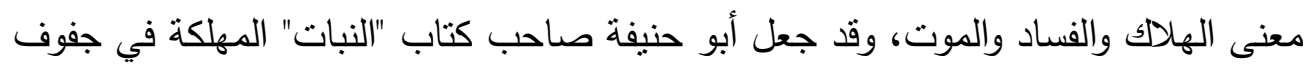

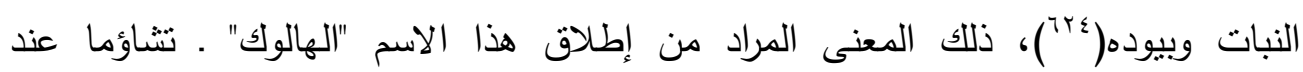
المصريين . على هذا النوع من النبات، الذي يعيش على ما يستمده من غذاء من الزرع الأصلي، كالفول ونحوه، مما يعرضه للإصابة بالأمراض فيضعفه ويقلل من إنتاجه.

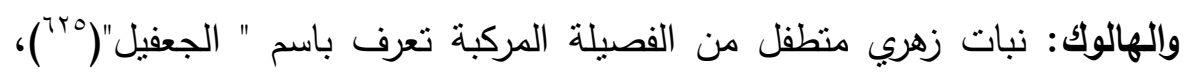

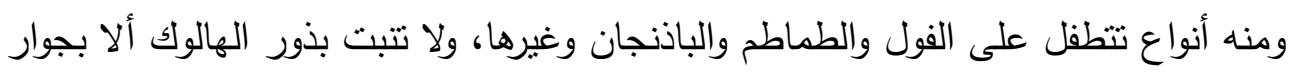

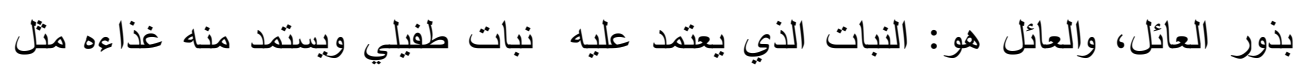

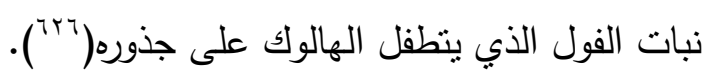

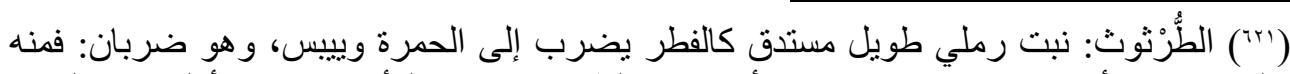

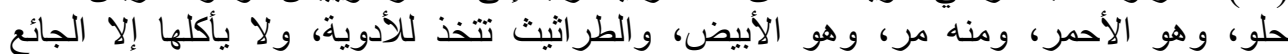

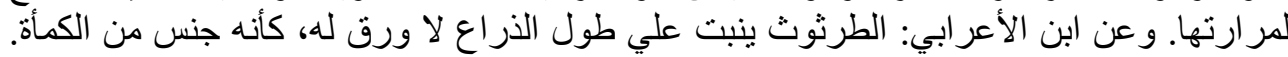

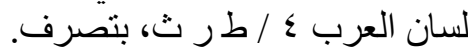

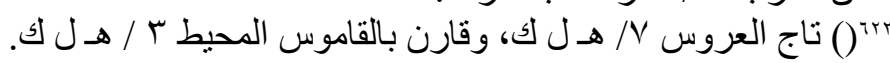

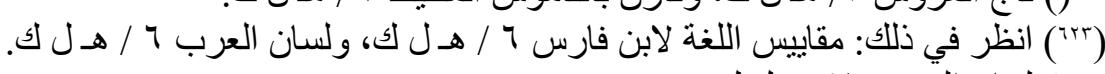

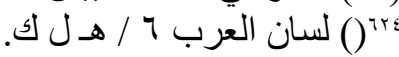

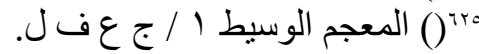

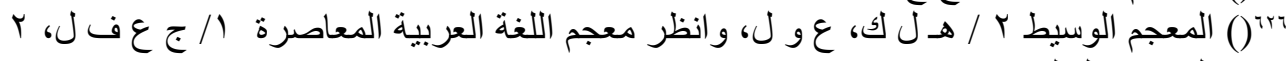

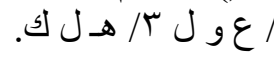


د/ مصطفى عبد الهادي عبد الستار محمد

19

ذكر الزبيدي أن الوَسب بالفتح: خشب يُجْحَلُ ـ وفي بعض نسخ القاموس : يوضع .

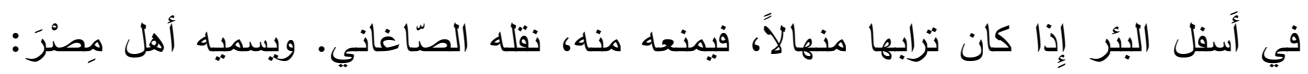

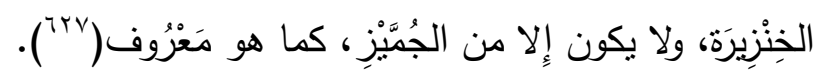

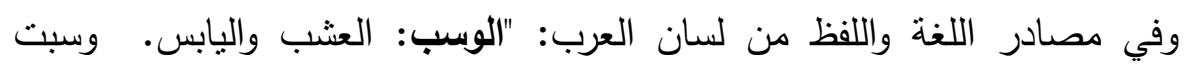

الأرض وأوسبت: كثر عشبها، ويقال لنباتها: الوِسب بالكسر، والوَسب: خشب يوضع في في

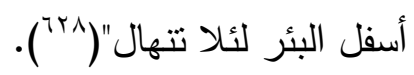

وأضاف الزبيدي في التكملة وصف ما رآه في مصر عند حفر الفلاحين والبنائين

آبار السواقي، فذكر أن الخِنزيرة بالكسر خشب من أشجار الجُمَّزيز ،رمي بها في جوف البئر

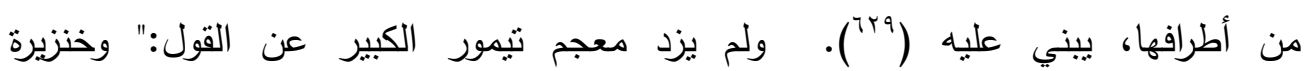

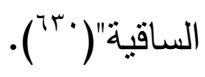

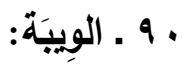

من الألفاظ الثائعة على ألسنة المصربين في المكاييل لفظ الوِيبَة، وقد عرض لها

الزبيدي في تاجه. قال: "والوبية على وزن شيبة: اثثان أو أربعة وعشرون مدا، والمد يأني بيانه في ( م ك ك ) لم يذكره الجوهري ولا ابن فارس، بل توقف فيه ابن دريد، والصحيح أنها مولدة، استعملها أهل الثام ومصر وإفريقية"( آبام).

لإبT) تاج العروس / / / و س ب، وقارن بالقاموس المحيط للفيروزآبادي // و س ب، و التكملة والذيل والصلة

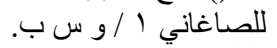

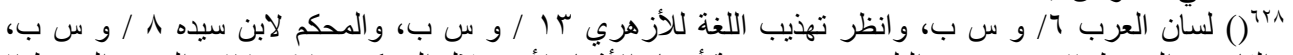

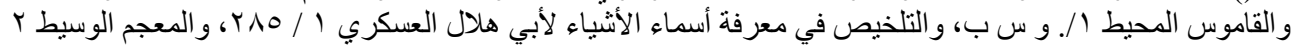
/و س ب ب.

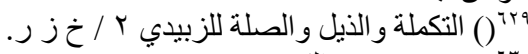

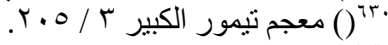

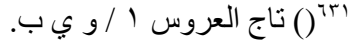


ما نسبه الزبيدي في تاج العروس إلى اللهجة المصرية

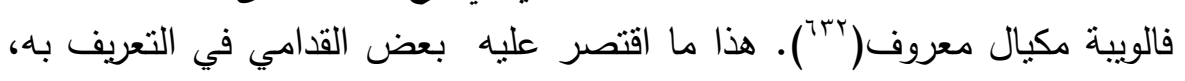

$$
\text { وصرح صاحب القاموس بأنه اثنان أو أربعة وعشرون مُدّا (بrآج). }
$$

وفي المقاييس والمكاييل:" الويية: مكيال مصري بالدرجة الأولى، كان يعادل في

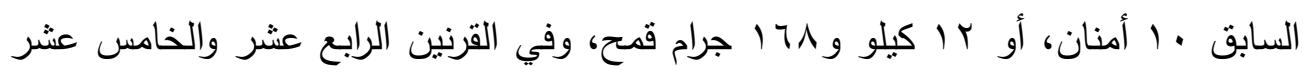

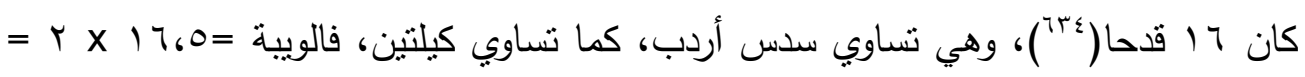

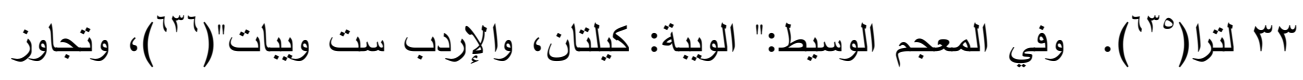

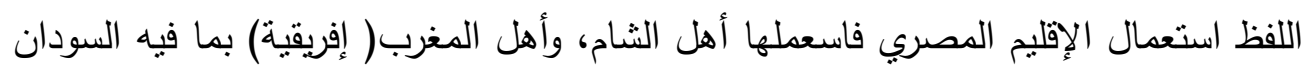
أيضا، وقد أهمل النظر فيه بعض القدامي، كالجوهري، وابن فارس، وذهب الثيخ الزبيدي أن

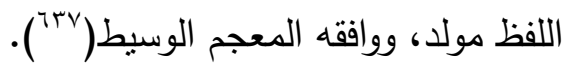

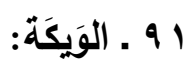

الوِيكَة: نوع من الطعام يعرفه المصريون وأهل السودان، يتخذونه من ثمر نبات

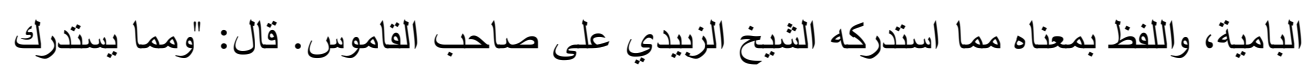

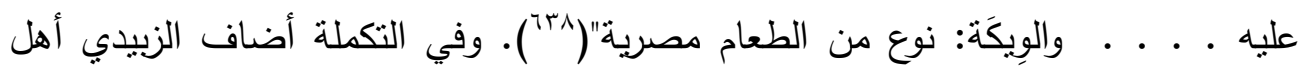
السودان في الاستعمال المصري لهذا اللفظ. قال: "والويكة: نوع من الطعام يتخذه

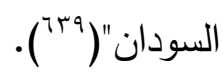

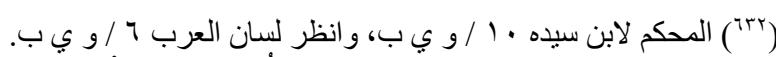

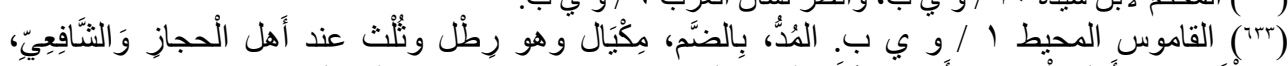

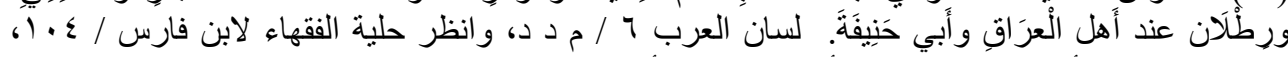

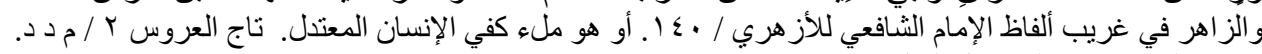

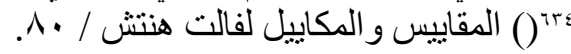

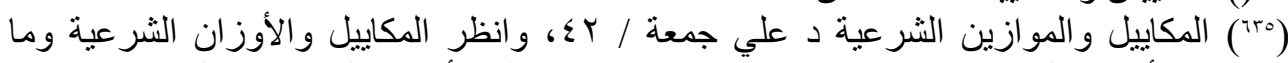

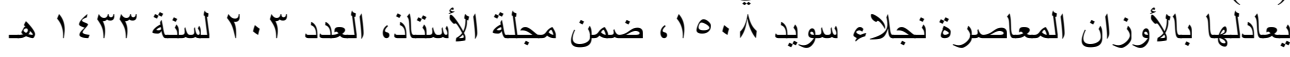

$$
\begin{aligned}
& \text { بr"() المعجم الوسيط r / / و ي ب، و وانظر محيط المحيط / و ي ب. } \\
& \text { ( ) }
\end{aligned}
$$

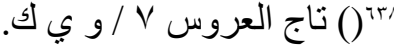

$$
\begin{aligned}
& \text { arar() التكملة و الذيل و الصلة ه ه / و و ي ك. }
\end{aligned}
$$


د/ مصطفى عبد الهادي عبد الستار محمد سمفار

وفي بعض المعاجم، واللفظ من تكملة المعاجم العربية لدوزي:"ويكة: بامية: نبات

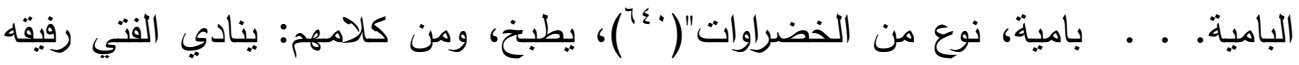

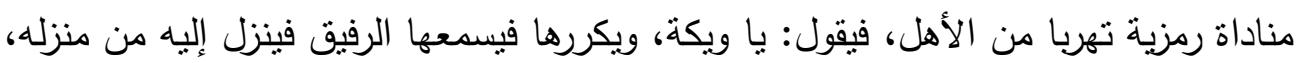

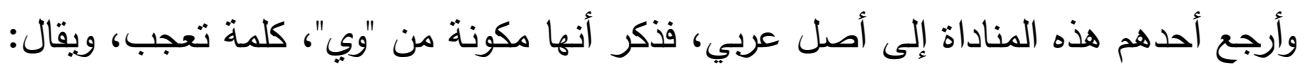
ويك، وويَّ لعبداله، وويّ يكني بها عن الويل، فيقال: ويك أتسمع قولي، وقال عنترة:

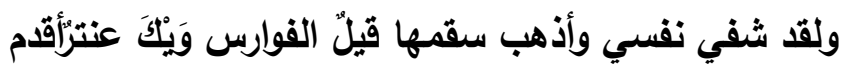

فأخذها العامة، وقالوا: يا وِيكَة(1)ج"). ولا يبعد أن تكون هذه المناداة مأخوذة مما أصلناه عند الزبيدي أب مأخوذة من الويكة بمعني البامية على عادة المنادين من الباعة على ما بييعونه من طعام أو ثمار أو أمتعة، وهو الأرجح في نظري.

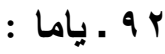

استنرك الزبيدي هذا اللفظ بمعناه العامي المصري على المصنف، فقال: " وومما

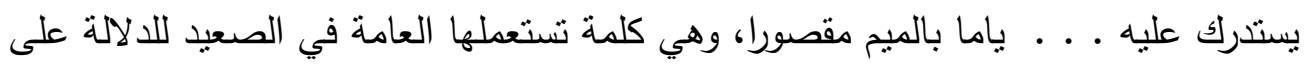

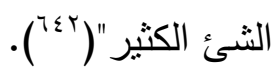

قلت: واستعمال " ياما" بهذا المعنى ليس مقصورا على إقليم الصعيد من مصر ، بل هو أيضا مسموع مستعمل في الوجه البحري، يقولون: ياما للالالة على الكثرة اكتفاء، ولعل في إثارة الزبيدي" ممالا" دليلا على أن القصد لبس قصره على أهل الصعيد، بل بهذا القيد " ممالا"، أما غيرهم فينطقونه بالفتح من غير إمالة فيه على نحو ما هو منطوق به به الآن في الوجه البحري. وفي بعض مصادر لغة العامة، واللفظ من المحكم في أصول الكلمات العامية: " يامَه، تسأل: هل عندك كثير من الثئ الفلاني؟ فتجاوب: يامَه، أعني: كثيرا، يمَا:

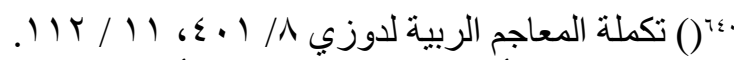

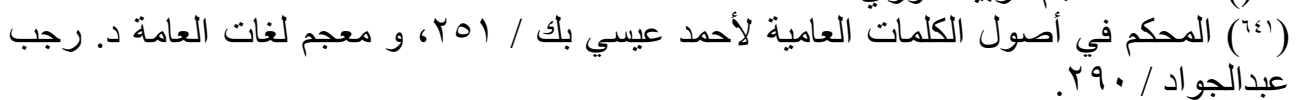

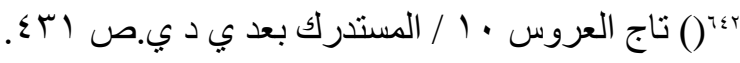


ما نسبه الزبيدي في تاج العروس إلى اللهجة المصرية

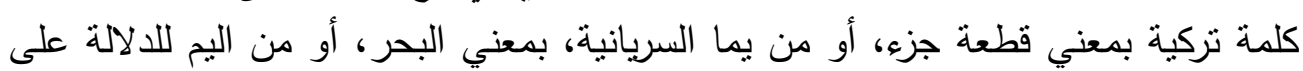

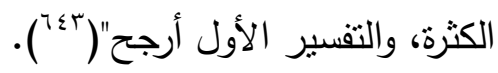

وذهب الثيخ المغربي صاحب دفع الإصر عن كلام أهل مصر إلى أن المصريين

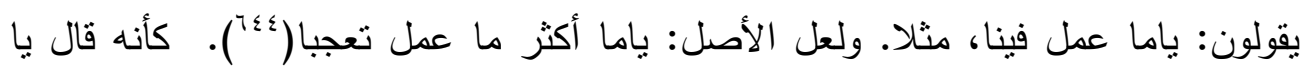

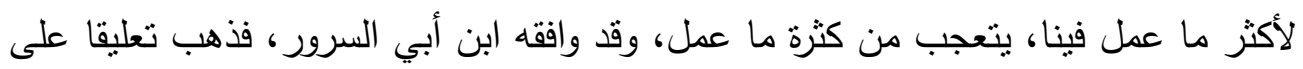

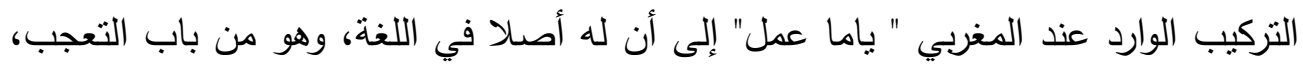
ووافقهما أحد المحدثين(؟0) في أحد قوليه، والقول الآخر أنها مأخوذة من الجم بمعني الكثير من كل شئ، أصلها:"جمَّا"، فأبدلوا الجيم ياء لقرب مخرجيهما، وفي التتزيل:" وتحبون المال

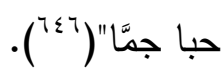

ويجاب عما عدَّه المغربي محتملا وقطع به ابن ابي السرور بأن المستعمل في

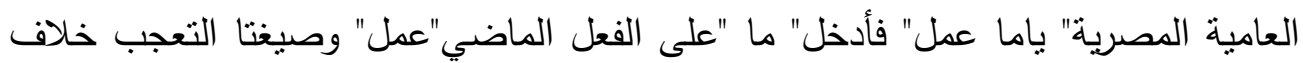
ذللك في اللفظ، فالتعجب القياسي له صيغتان في اللفظ على "أفعل" و "أفعل به" نحو: ما أحسن زيدا، وأحسن به، ولا يأني على"فَعَل" كما في مثال العامية المصرية عند الثيخ

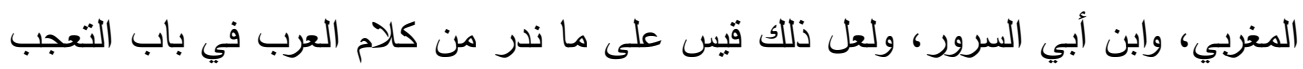

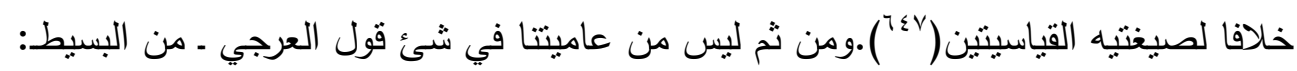

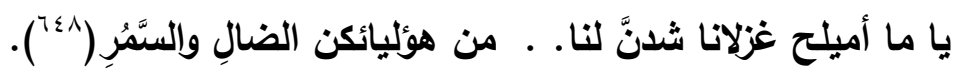

وإن وافق في اللفظ والصورة النطق العامي المصري الثائع، فهي "يا" التي للتنبيه دخلت على"ما" التعجبية، قصد منه التعجب.

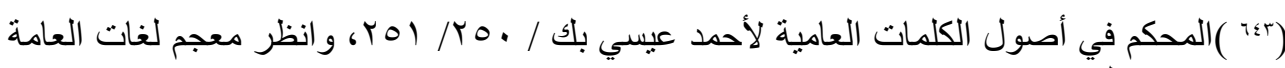

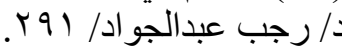

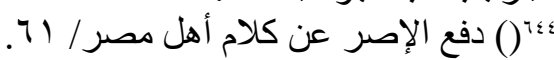

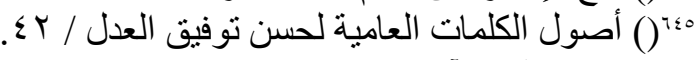

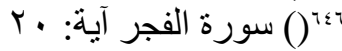

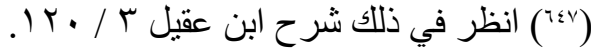

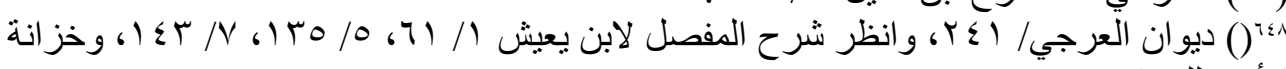

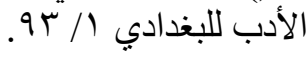




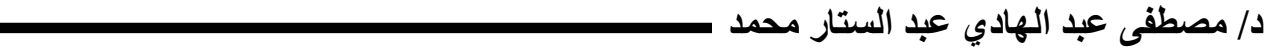
وقد وردت" ياما" على ماهو شائع في العامية المصرية في أبيات للرقيق القيرواني

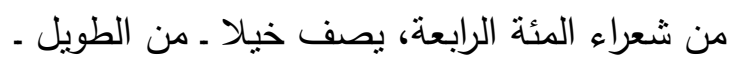

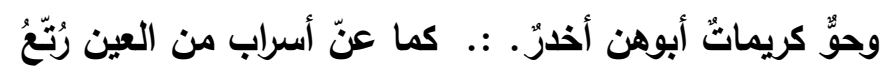

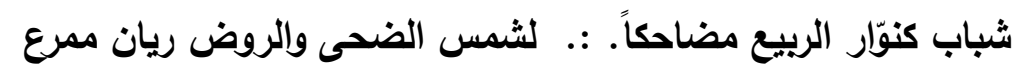

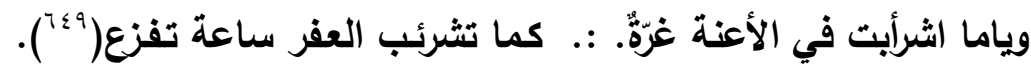

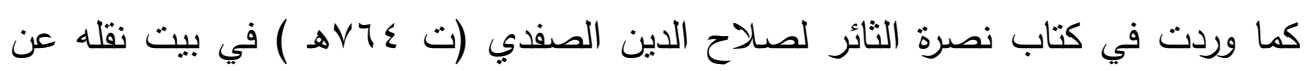

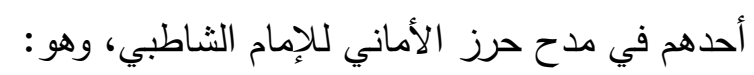

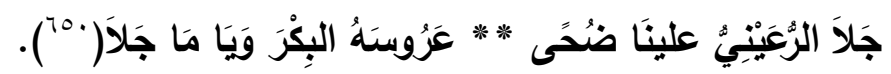

أي كثير.

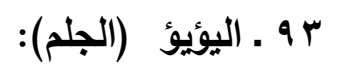

قال الزبيدي: "واليأياء أيضا صياح اليؤيؤ، وهو اسم لطائر من الجوارح، كالباشق

بارد رطب لأنه أصبر منه نفسا وأثقل حركة، قال ويسميه أهل مصر والثام الجَلَم لخفة وهئ

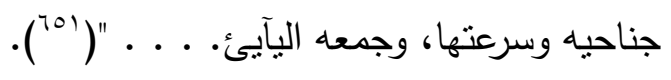

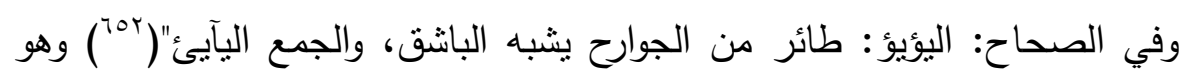

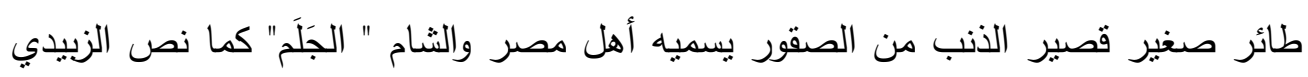

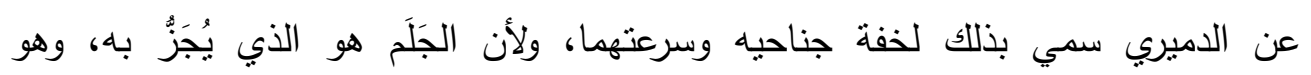

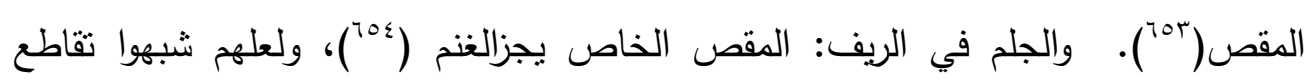
جناحيه بتقاطع طرفي المقص مع السرعة والخفة فيهما.

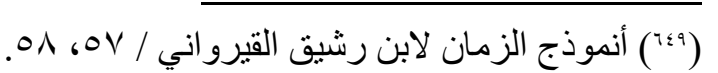

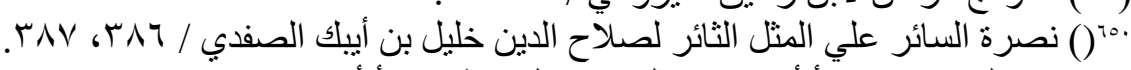

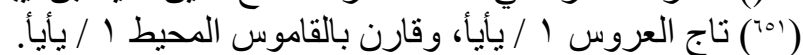

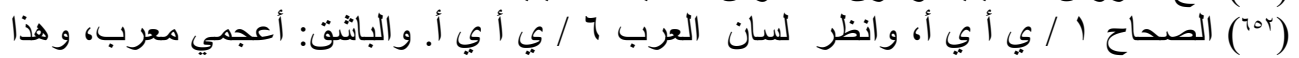

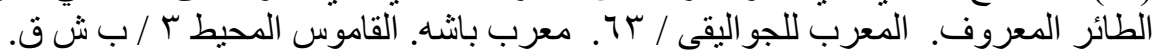

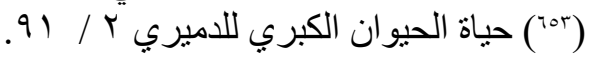

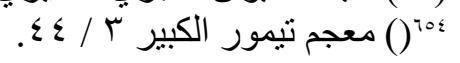

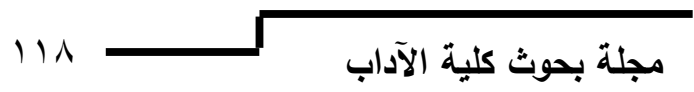


ما نسبه الزبيدي في تاج العروس إلى اللهجة المصرية

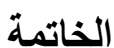

وبعد فقد تناولت بالدراسة في بحثي هذا جانبا مهما من اللهجة الدصرية، وحاولت فيه

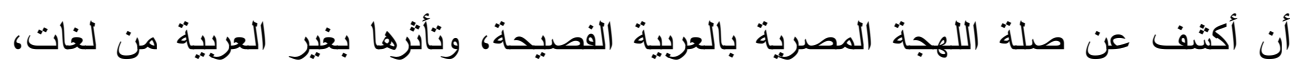

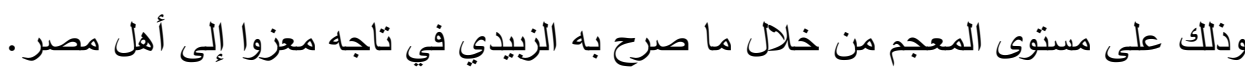
وقد كان من جملة ما قصدته في هذا البحث هو محاولة الوصول إلى جذور العامية المصرية وربطها بأصولها العربية متى أمكن ذلك مع الأخذ في الحسبان أن دراسة العامية العادية

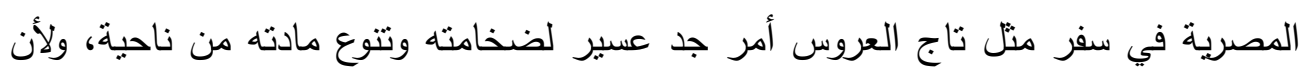
الدةة الزمنية بينتا وبين مؤلفه كبيرة تكفي لإحداث تطور لغوي في شني مستويات اللغة

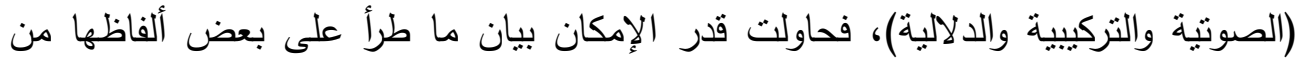

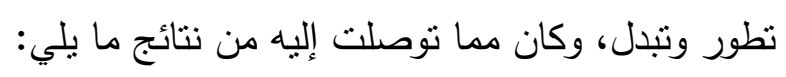

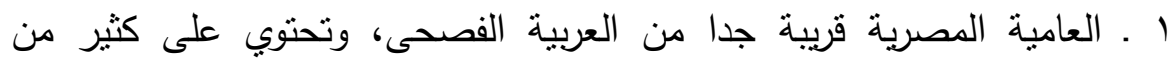
مفرداتها،وتتفق معها في معظم نظامها الصوتي والبنيوب، ولا نبالغ إن قلنا: إن العامية العادية المصرية هي أقرب العاميات المعاصرة إلى العربية الفصيحة، أو من أقربها.

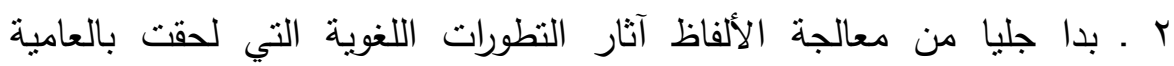

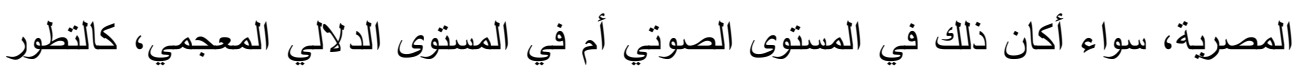

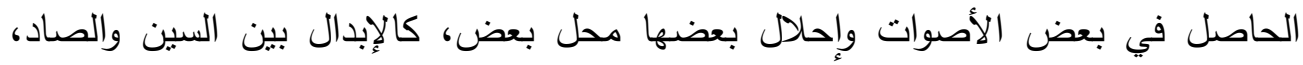
والذال والدال رأينا ذلك في صفط وسفط، وصنط وسنط، وذقن ودقن، وبين القاف والههزة كما

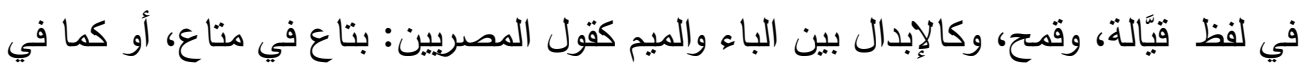

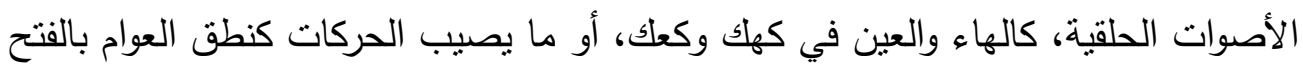
أو بالكسر مثلا والنطق الفصيح بالعكس من ذلك، ونحن نسمع عامة المصريين يقولون:

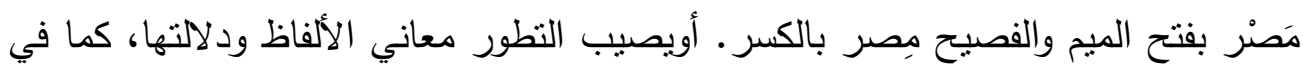
لفظ " الكَفر" وإطلاقها على ما نباعد عن الديار ومحلات الناس، ثم إطلاقها على القرية الصغيرة، ثم هي الآن تطلق على القرية مطلقا صغيرة كانت أو كبيرة، وعلى المدينة، ككفر الدوار، وكفر الزيات. 
د/ مصطفى عبد الهادي عبد الستار محمد

r ـ التطور الذي لحق العامية المصرية في متتها وأصاب معانيها مع ما اعترى مادي أصواتها من تطور كان من الكثرة بمكان ولا نبالغ إن قلنا إن العامية المصرية بمعجمها الضخم وقربها الثديد من العربية في الوقت نفسه تمثل لغة قائمة بذاتها قادرة على تلبية حاجات مستعمليها في حياتهم اليومية، وإن لم ترق إلى مستوى اللغة الأدبية النموذجية لهنية الفصحى)، أو إلى حد الانفصال والتباعد عن لغتها العربية، فهى ترتبط بها من حيث كونها لهجة متفرعة منها. ع ـ تأثرت اللهجة المصرية بكثير من اللغات المجاورة لها بحكم الجغرافية والدين واحتكالك الشعوب، وقد تعرضت هذه الدراسة للعديد من الألفاظ المعربة والدخيلة، فكثفت عن لن لن

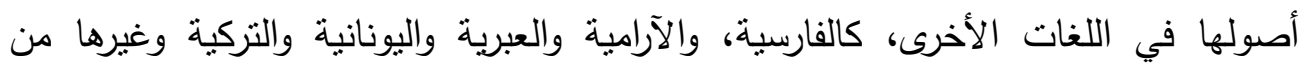

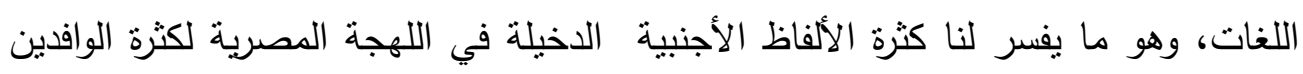

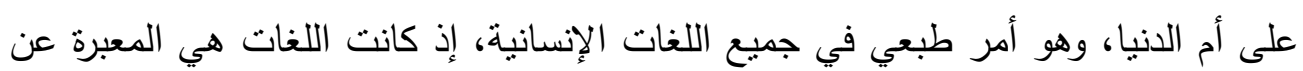
اختلاط الثعوب وتداخلها تأثثرا وتأثرا، والعربية ممثلة في اللهجة المصرية كغيرها من اللغات

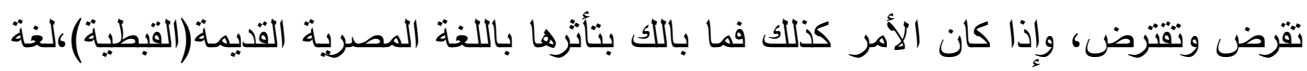
المصريين الأصلية، فقد احتفظت بالكثير من ألفاظها.

ه . تبين من البحث أن المصرية تحتوي بداخلها على عاميات متعددة ـ لهجات محلية ـ بتعدد وتتوع أقاليم القطر المصري، فهنالك العامية المصرية القاهرية، والتي فرضت سبطرتها على كثير من الأقاليم المجاورة، وهناك لهجة الصعيد، ولهجة المناطق الثرقية والغربية ولهجة السواحل كدمياط والإسكندرية، إلى غير ذلك من لهجات داخل الدولة، وقد عزا الزبيدي بعض الألفاظ إلى عامية بعض هذه الأقاليم.

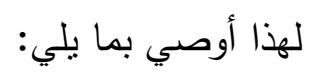

ا. العمل على تضبيق الفجوة وتقريب المسافة بين العامية ومنها المصرية والعربية الفصحى، وذلك باعتماد القرآن الكريم كوسيلة وعلاج لهذا الخلل بتعميم تدريسه وتحفيظه في المراحل التعليمية المختلفة، وفي مختلف التخصصات حفظا وتجويدا لإجادة النطق بالعربية الفصحى نطقا سليما، ولتتمية الثروة اللغوية. 


\section{ما نسبه الزبيدي في تاج العروس إلى اللهجة المصرية}

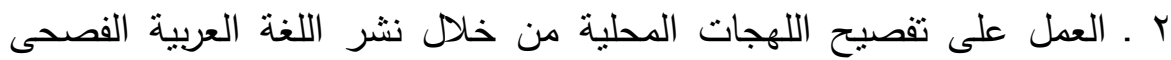
والتوسع في استخدامها نطقا وسماعا وكتابة، وذلك باستخدام وسائل الإعلام السموعة والمقروءة والمرئية، والالتزام بها في المراحل التعليمية المختلفة، وتعيم استخدامها في شتى ولتى دوائر الدولة ومؤسساتها، وسن القوانين اللازمة لذللك، وتقديم الدعم المادي والمعنوي للنهوض التهرئ بها من جديد، يضاف إلى ذلك الحد من استعمال الألفاظ الدخيلة ،والدعوة إلى إحلال اللفاظ العربية محلها. r. النظر في قرارات المجامع اللغوية في عالمنا العربي من أجل العمل على توحيدها وتطبيقها.

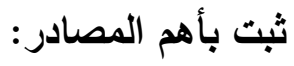

$$
\text { ثأنا: القآيآن الكريم: }
$$

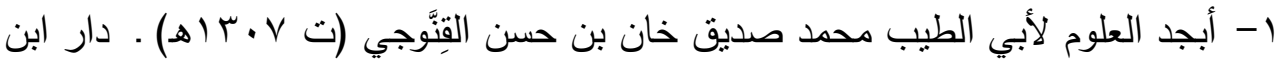

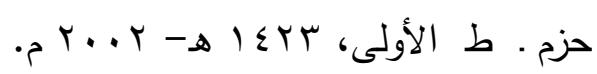

r- الإبدال لأبي الطيب عبدالواحد بن على اللغوي المتوفي سنة الإهب هـ ـ تحقيق: عزالدين

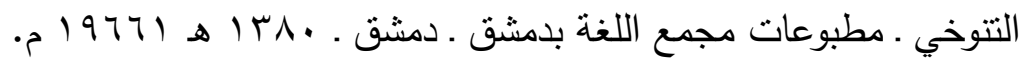

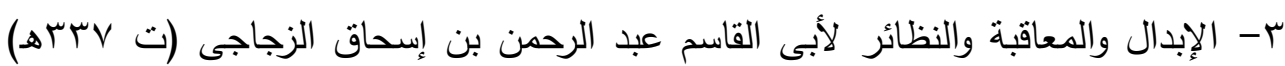
تحقيق عز الدين التتوخى ـدار صادر ـ بيروت. ع - آثار البلاد وأخبار العباد لزكريا بن محمد بن محمود القزوينى ـ دار صادر • بيروت . لبنان.

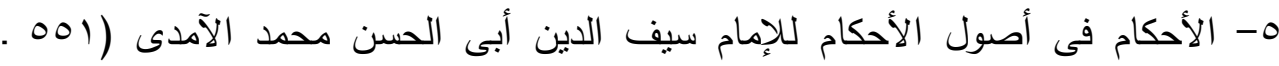
ابTهـ) مؤسسة الحلبى . القاهرة .

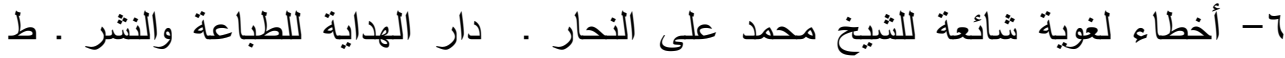
.01917 
د/ مصطقى عبد الهادي عبد الستار محمد

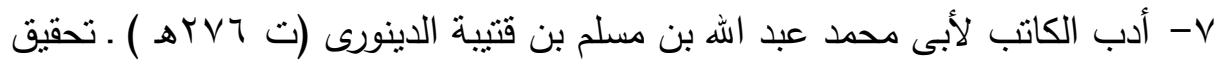

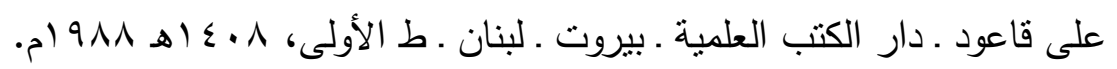

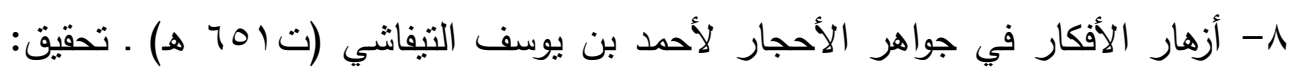

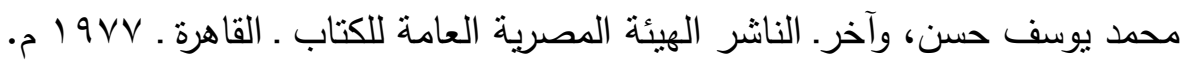
9- أساس البلاغة لجاراله أبى القاسم محمود بن عمر الزمخشرى (ت ^رهـه) ـ الهيئة المصرية العامة للكتاب ـ القاهرة ـ ط الثالثة.

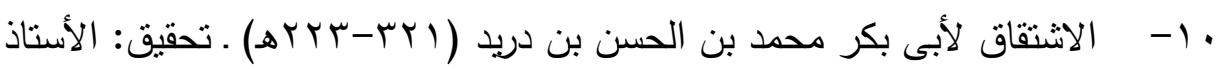

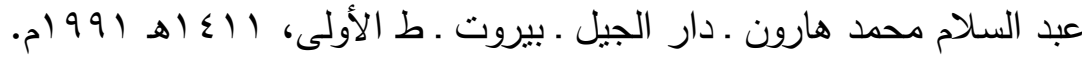
11- أصل الألفاظ العامية من اللغة المصرية القديمة لسامح مقار ـ ط الهيئة المصرية

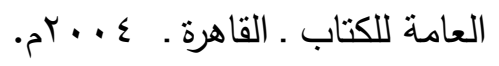

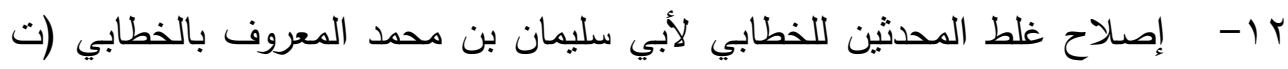

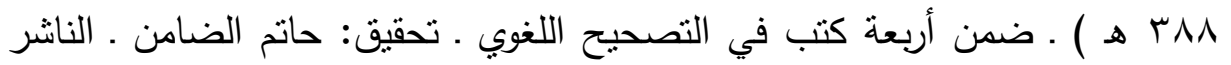

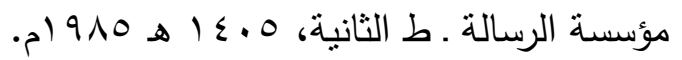

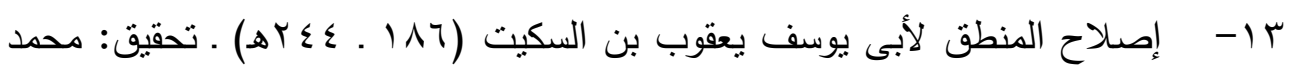
شاكر ، وعبد السلام هارون ـ دار المعارف المصرية ـ القاهرة . ط الرابعة.

ع ا- أصوات اللغة العربية لعبد الغفار حامد هلال ـ مطبعة الجبلاوى ـ الترعة البولاقية .

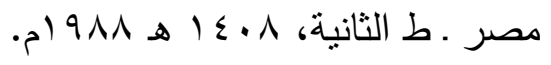
10- أصول الكلمات العامية لحسن أفندي توفيق العدل . مطبعة مدرسة والدة عباس

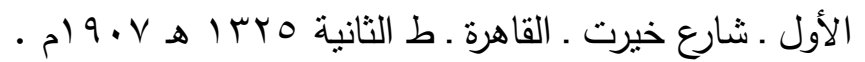
7 ا- الأصول اللغوبة المشتركة بين العربية والآرامية والسريانية دراسة مقارنة لمازن

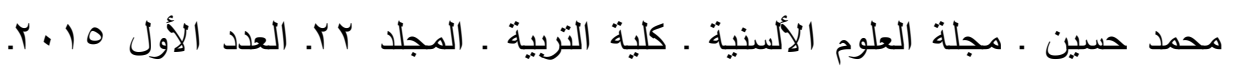
جامعة بابل ـ مركز الدراسات البابلية ـ العراق.

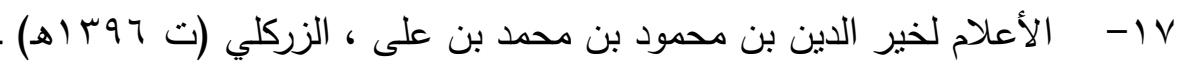

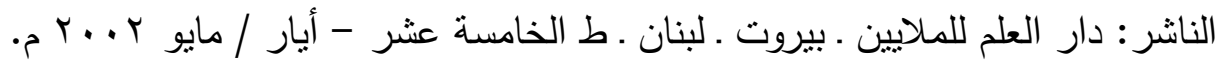

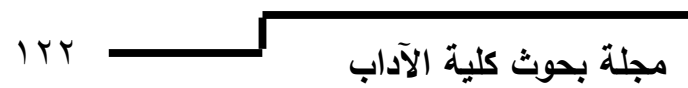




\section{ما نسبه الزبيدي في تاج العروس إلى اللهجة المصرية}

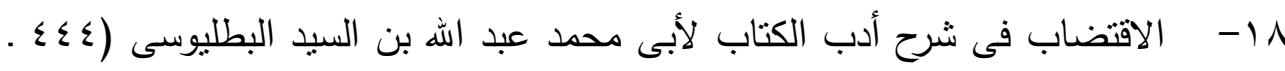

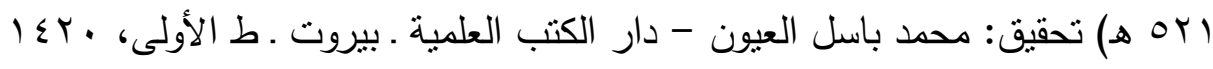

$$
\text { . } 1999
$$

9 - ألفاظ ريفية مصرية في القرن السابع عشر : دراسة في كتاب هز القحوف في شرح

قصيدة أبي شادوف للشربيني (يوسف بن محمد بن عبد الجواد بن خضر المصري) دراسة أعدها عليه عماد عبد السلام رؤوف ـ الدكتب العربي للمعارف ـ القاهرة،

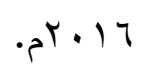

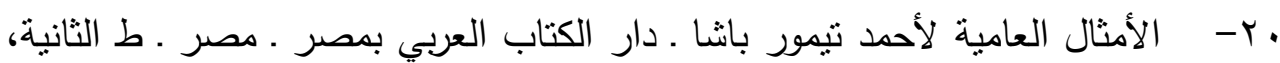

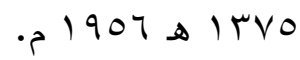

ا ب- أنموذج الزمان لابن رشيق القيرواني ـ تحقيق: بشير البكوش، وآخر. الدار التونسية

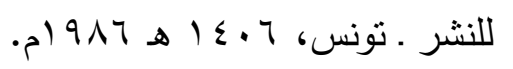

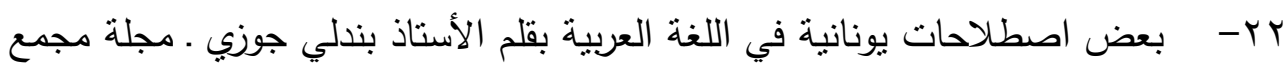

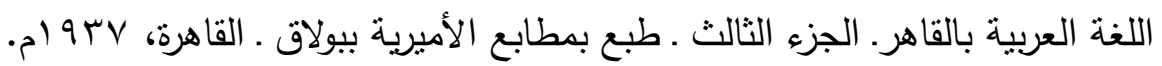

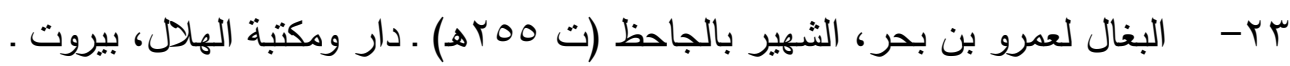

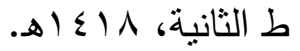

ع ب- تاج العروس للسيد محمد مرتضى الزبيدي (

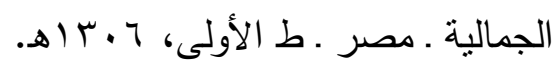

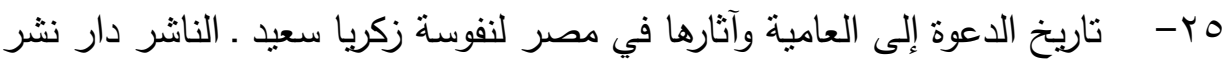

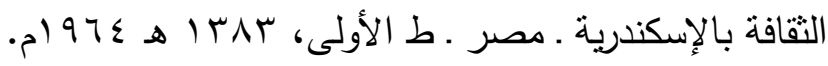

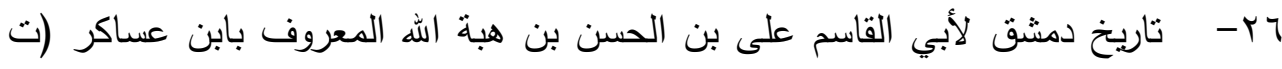

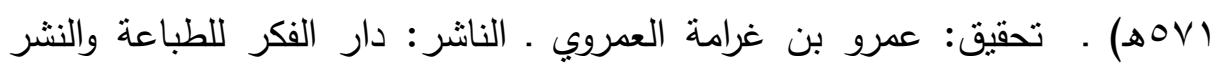

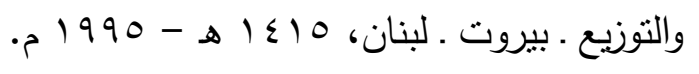

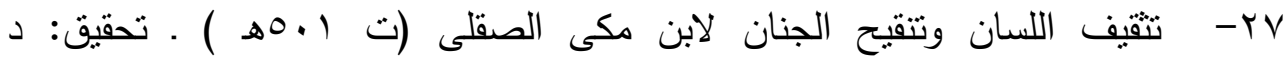

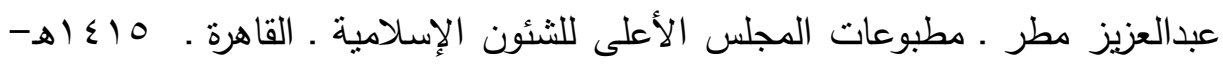


د/ مصطقى عبد الهادي عبد الستار محمد

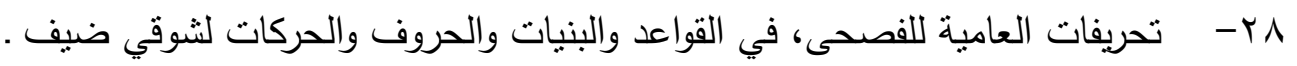

الناشر : دار المعارف بالقاهرة ـ مصر .

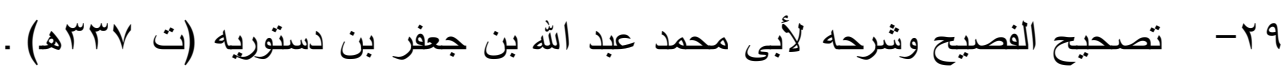

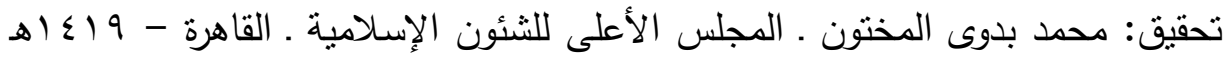

. $) 991$

• ب- التطور اللغوي مظاهره وعلله وقوانينه لرمضان عبدالتواب ـ الناشر: مكتبة الخانجي

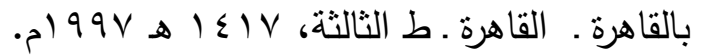

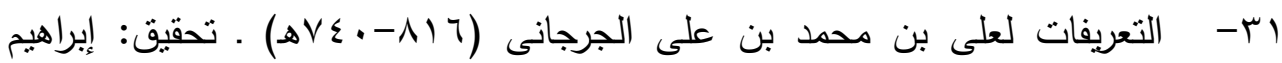
الإبيارى - دار الريان للتراث ـ القاهرة.

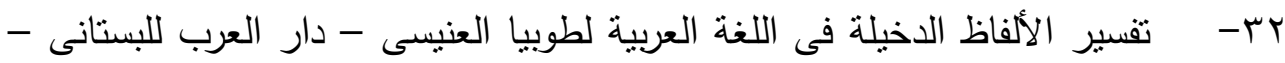
الفجالة - القاهرة. ع ع 97 1 ـ 970 (م.

rr- تقويم اللسان لجمال الدين أبي الفرج عبد الرحمن بن محمد الجوزي (ت Vوه هـ) .

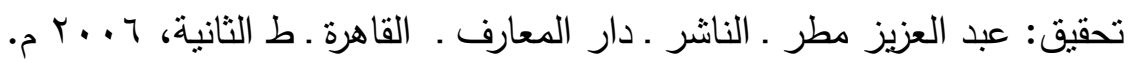

ع ب- تكملة المعاجم العربية لرينهارت بيتز آن دُوزي (المتوفى: . ب اهـ) نقله إلى العربية

وعلق عليه : محمَّد سَليم النعَيمي، وجمال الخياط ـ الناشر : وزارة التقافة والإعلام .

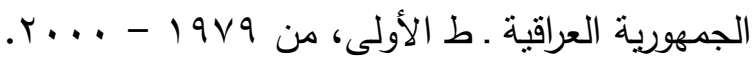

هץ- التكملة والذيل والصلة للسيد محمد مرتضى الحسينى الزبيدى ـ تحقيق: مصطفى منى

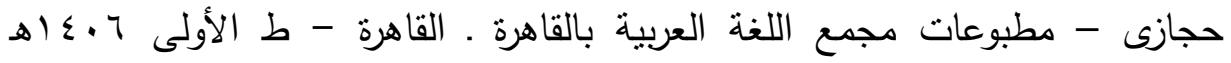
. 91917

جب- التكملة والذيل والصلة للصاغانى - تحقيق عبد العليم الطحاوى وآخر ـ القاهرة .

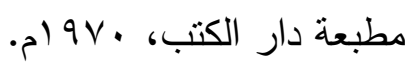

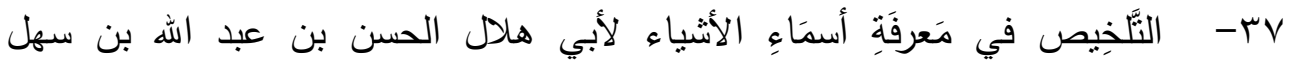
العسكري (ت 90"هـ) ـ تحقيق: عزة حسن ـ الناشر: دار طلاس للاراسات والترجمة

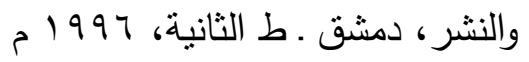


ما نسبه الزبيدي في تاج العروس إلى اللهجة المصرية

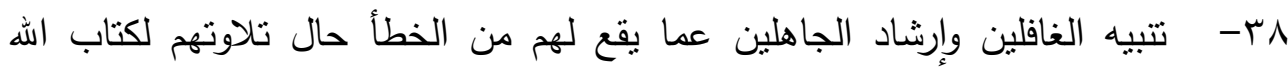

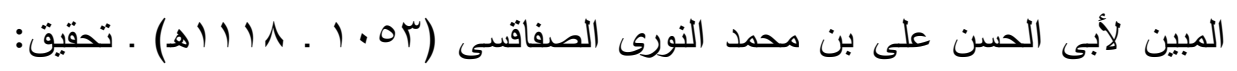

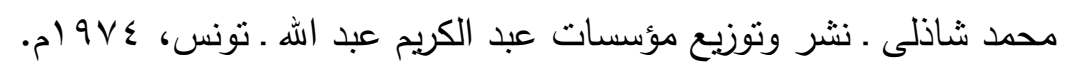

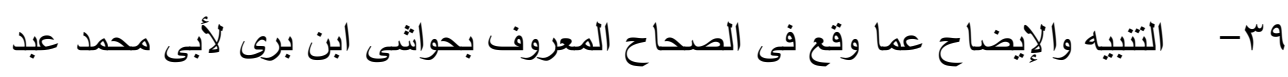

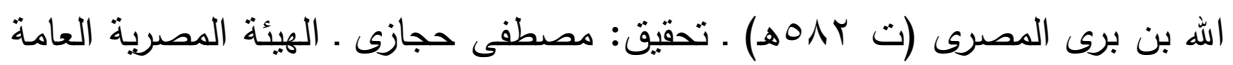

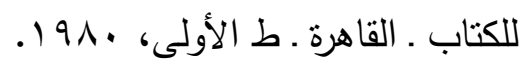

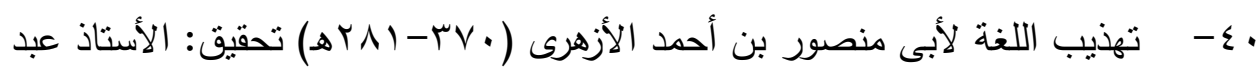

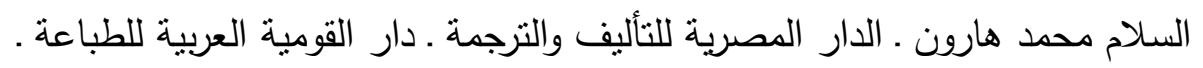

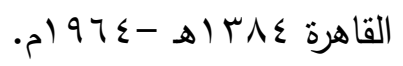

اء - تيسيرات لغوية لشوقي ضيف ـ ط دار المعارف المصرية ـ القاهرة.

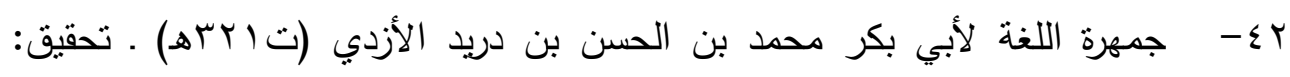

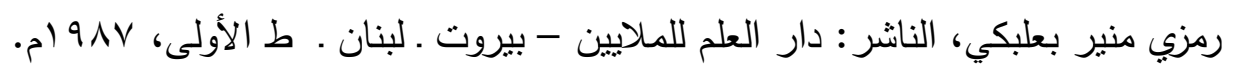

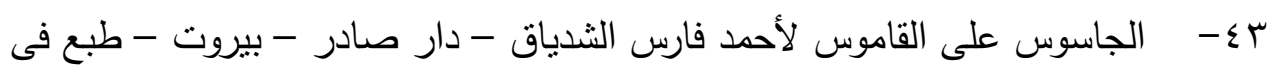
مطبعة الجوائب، 99 ب ام.

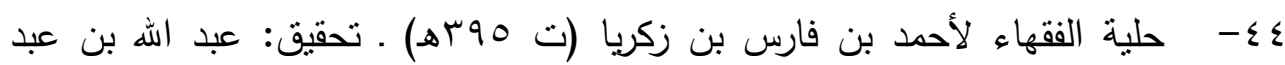

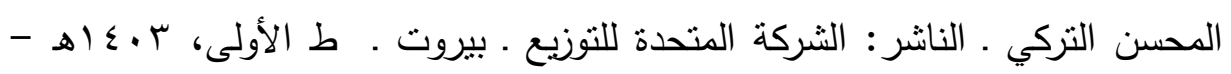
5) 914

0ـ - حواشي ابن برى وابن ظفر على درة الغواص فى أوهام الخواص للحريرى ـ تحقيق:

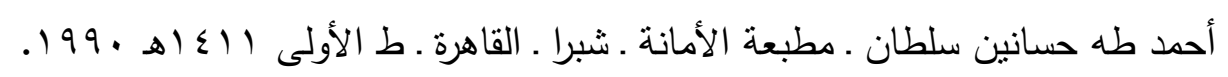

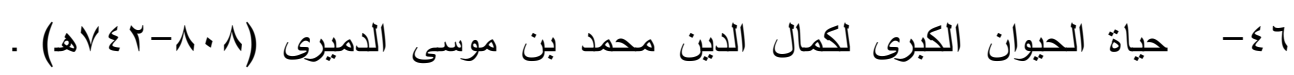
تهذيب أسعد الفارسى - دار طلاس للاراسات والترجمة ـ دمشق.

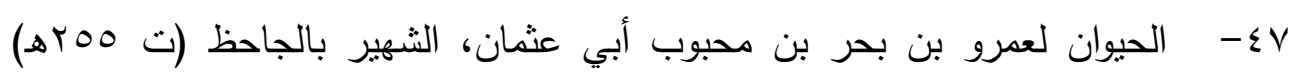

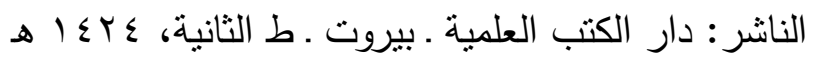




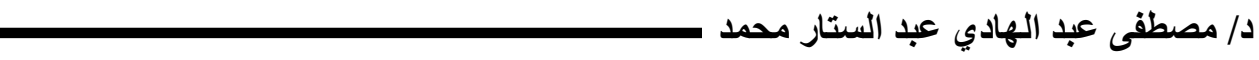

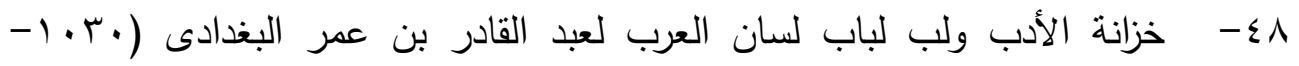

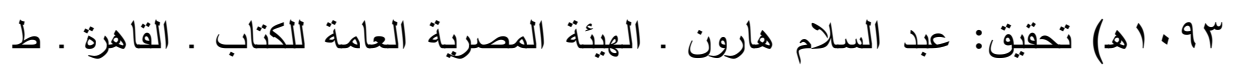
الثانية $9 \vee 9$

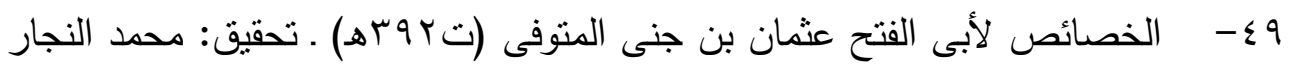

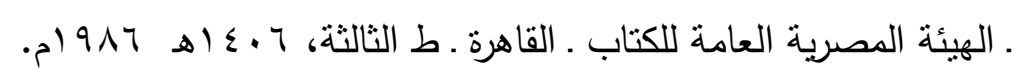

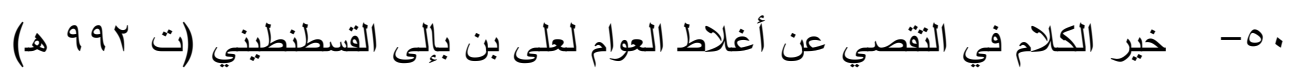

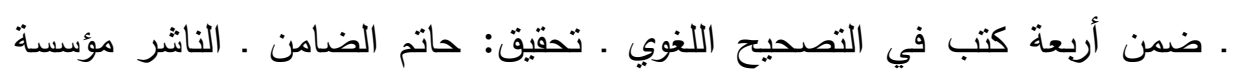

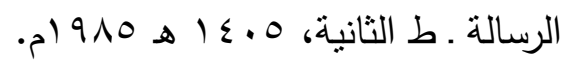

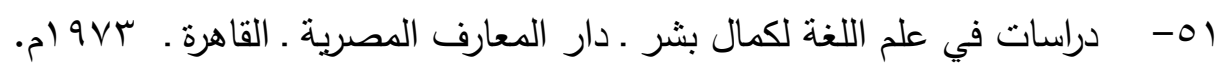

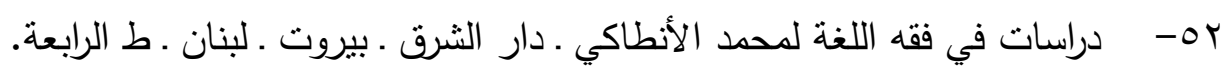

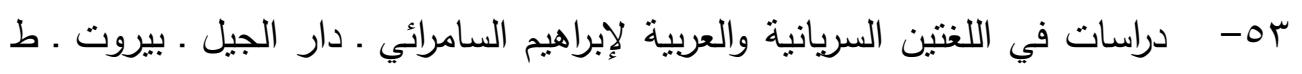
الأولى، 0 . ك أهـ 910 (م.

ـه- دعاة العامية بين الحقائق والأباطيل لمحد عبد الحفيظ العريان . ط الأولى،

$$
\text { . } 991 \text { ه } 911
$$

هo - دلالة الألفاظ لإبراهيم أنيس ـ الناشر : مكتبة الأنجلو المصرية ـ القاهرة ـ ط الثالثة، $.19 \times 7$

7ه- ديوان ربيعة بن مقروم · تحقيق: تماضر عبدالقادر · دار صادر · بيروت . ط

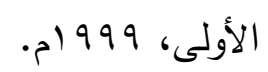

- V P ديوان الأخطل ـ تحقيق: فخر الدين قباوة ـ دار الفكر (دمشق - سورية)، ودار

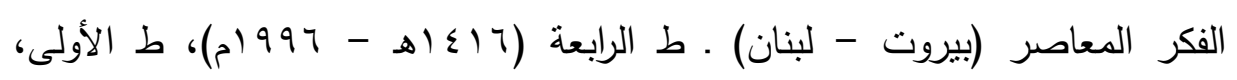
. $9 \times 1)$

101- ديوان العرجي · تحقيق: سجيع جميل الجبيلي . دار صادر بيروت . ط الأولي . 1991 


\section{ما نسبه الزبيدي في تاج العروس إلى اللهجة المصرية}

9ه- دفع الإصرعن كلام أهل مصر لجمال الدين يوسف بن زكريا المغربي ـ تحقيق:

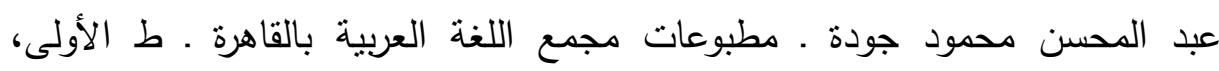

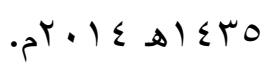

• - رحلة ابن بطوطة المسماة (تحفة النظار في غرائب الأمصار وعجائب الأسفار)

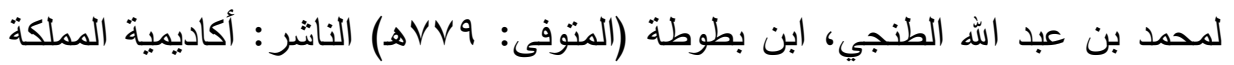

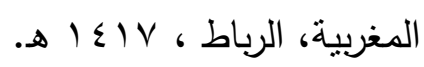

آ- رفع الإصر عن قضاة مصر لأبي الفضل أحمد بن على بن حجر العسقلاني (المتوفى: 10rهـ) . تحقيق:على محمد عمر- الناشر: مكتبة الخانجي، القاهرة . ط

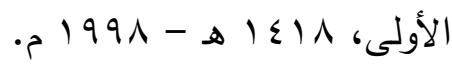

بآ- الزاهر فى غريب ألفاظ الإمام الثافعى لأبى منصور الأزهرى ـ تحقيق: شهاب الدين

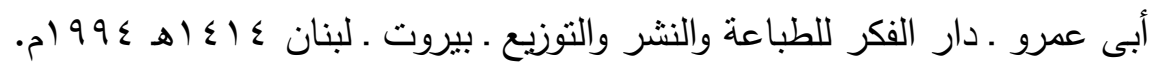

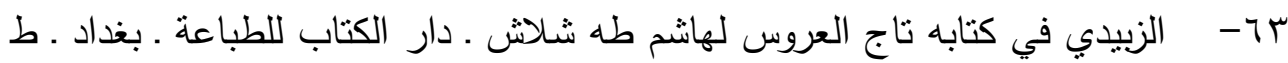

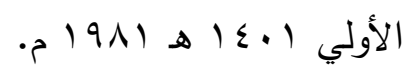

ء - - سر صناعة الإعراب لأبي الفتح عثمان بن جنى ـ تحقيق: حسن هنداوى ـ دار القلم

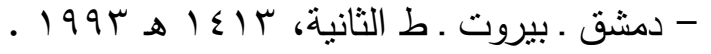

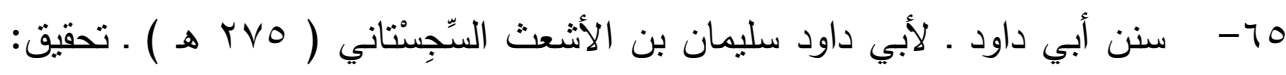
محمد محيي الدين عبد الحميد ـ الناشر: المكتبة العصرية ـ صيدا ـ بيروت.

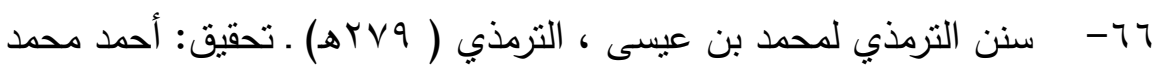

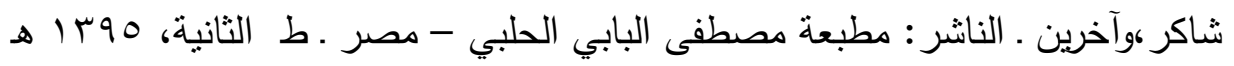
. $19 \vee 0-$

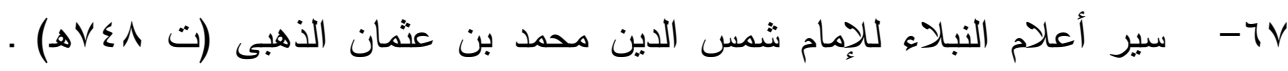
تحقيق: محيى الدين بن أبى سعيد ـ دار الفكر للطباعة والنشر والتوزيع ـ بيروت ـ لبنان. 1 צ- شرح ابن عقيل لبهاء الدين عبد الله بن عقيل العقيلى الهمدانى المصرى (1917هـ) .

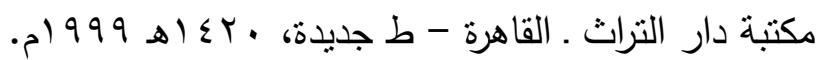




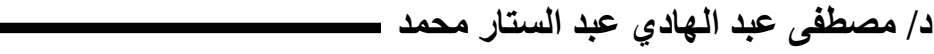

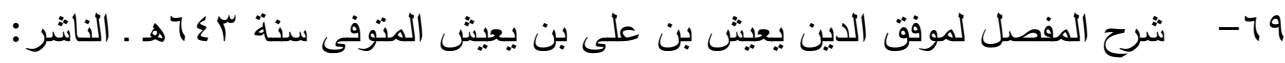
مكتبة المتنبى ـ القاهرة. • - Vفاء الغليل فيما وقع في كلام العرب من الدخيل، لثهاب الدين أحمد الخفاجي المصري، المتوفي (97 • (هـ) . تحقيق: محمد كثاش ـ دار الكتب العلمية، بيروت،

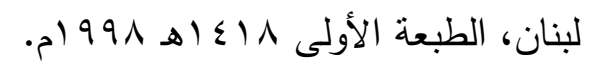

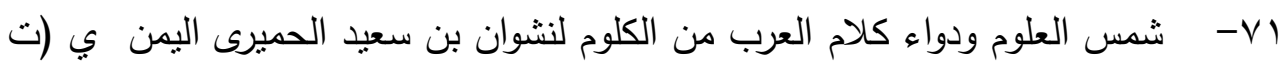
roV هـ) ـ تحقيق: حسين بن عبد الله العمري، وآخرين - الناثر : دار الفكر المعاصر

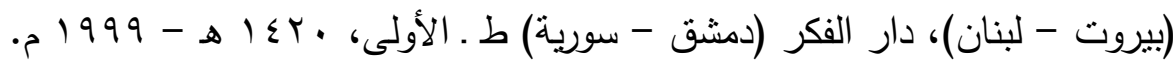

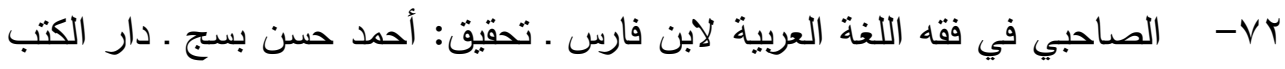

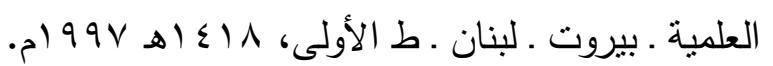

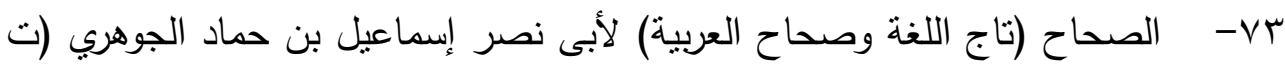

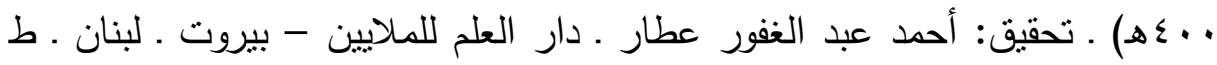

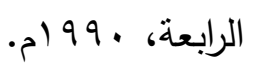

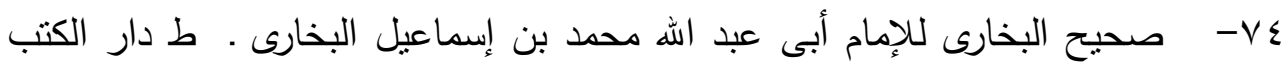

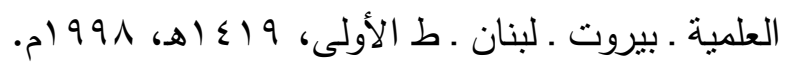
-Vo - صحيح مسلم للإمام أبى الحسن مسلم بن الحجاج بن مسلم القشيرى النيسابورى

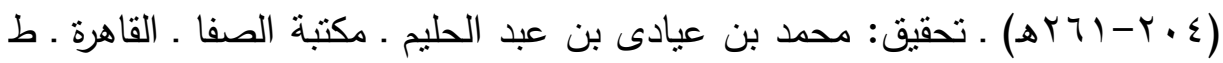

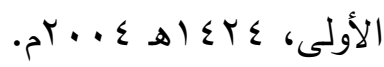

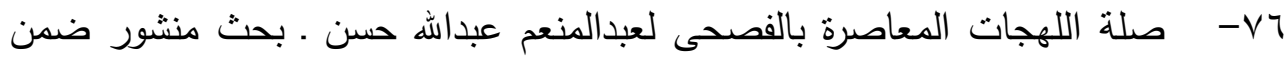
المؤتمر الدولي "اللغة العربية ومواكبة العصر" ـ الجامعة الإسلامية بالمدينة المنورة .

$$
\text { السعودية rrع ا هـ r I أ.r م. }
$$

ع -VV

$$
\text { المؤرخ (ت VTr I أه) ـ الناشر : دار الجيل ـ بيروت. }
$$

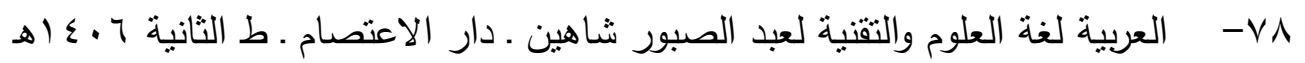

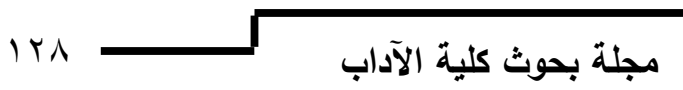


ما نسبه الزبيدي في تاج العروس إلى اللهجة المصرية

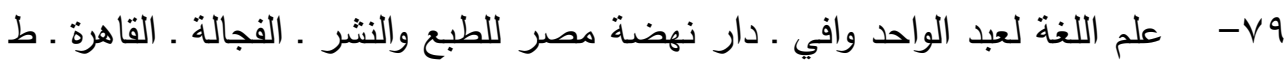
التاسعة.

• ^- علم اللغة بين التراث والمعاصرة لعاطف مدكور ـ دار الثقافة للنشر والتوزيع .

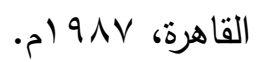

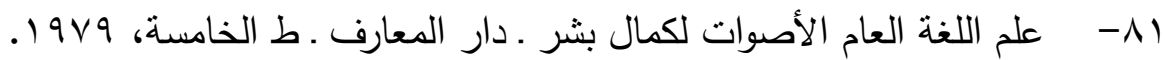

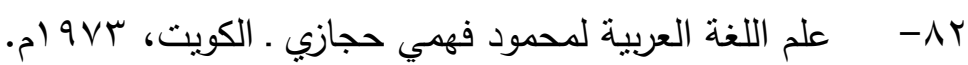
rی- العامي الفصيح في المعجم الوسيط لأمين على السيد . مطبوعات مجمع اللغة

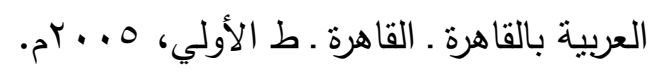

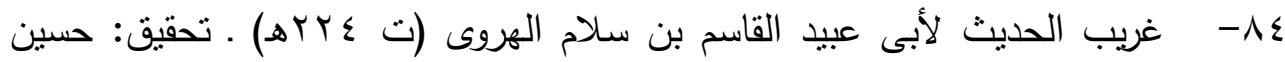
محمد محمد شرف، وآخر . مطبوعات مجمع اللغة العربية بالقاهرة ـ القاهرة، 9 . عـ اهـ . $) 9 \wedge 9$

1-10- الفائق فى غريب الحديث للزمخشرى ـ تحقيق: إبراهيم شمس الدين ـ دار الكتب

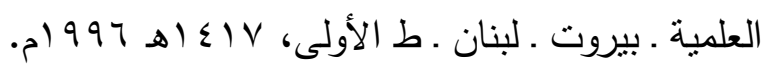

4ی- في اللهجات العربية لإبراهيم أنبس ـ مكتبة الأنجلو المصرية ـ القاهرة - ط الرابعة. -NV المعروف بعبد الحي الكتاني (المتوفى: r ب ا هـ) ـ تحقيق: إحسان عباس ـ الناشر : دار

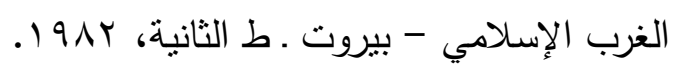

1ی1- القول المقتضب فيما وافق لغة أهل مصر من لغات العرب لمحمد بن أبي السرور الصِّدِّيق الثافعي ـ تحقيق: السيد إبراهيم سالم ـ وزارة التقافة والإرشّاد القومي ـ المؤسسة المصرية العامة للتإلف والترجمة والطباعة والنشر ـ. دار الفكر العربي. 19 - قاموس رد العامي إلى الفصيح للشيخ أحمد رضا العاملي . دار الرائد العربي .

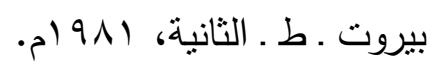

• - قاموس العادات والتقاليد والتعابير المصرية لأحمد أمين . الناشر كلمات عربية للترجمة والنشر . مصر ل 
د/ مصطقى عبد الهادي عبد الستار محمد

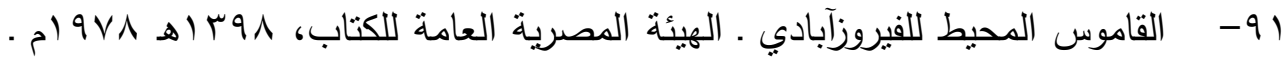

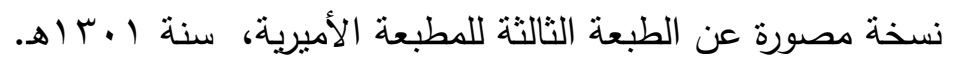

rq- الكامل فى اللغة والأدب لأبى العباس محمد بن يزيد المبرد (ت م10 هـ) . تحقيق:عبد الحميد هنداوى - دار الكتب العلمية - بيروت - لبنان . ط ط 9 اعـ أهـ .01999

بو- الكتاب لسيبويه (أبى بشر عمرو بن عثمان بن قنبر -.1 اهـ) ـ تحقيق: عبد السلام

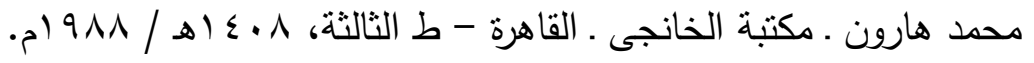

؟ - كتاب الإبدال لأبى يوسف يعقوب بن السكيت ـ تحقيق: حسين محمد شرف -

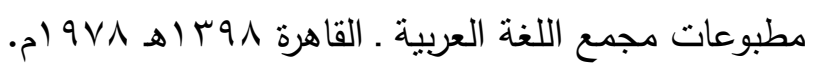

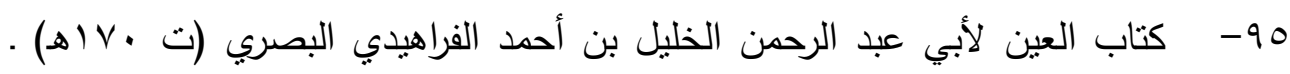
تحقيق: مهدي المخزومي، إبراهيم السامرائي . الناشر: دار ومكتبة الهلال ـ بيروت . لبنان.

9 - كتاب مميزات لغات العرب حفني ناصف ـ مطبعة السعادة بجوار محافظة مصر

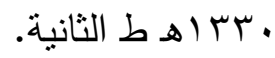

V - لحن العامة والتطور اللغوى لرمضان عبد التواب ـ مكتبة زهراء الشرق القاهرة ـ ط

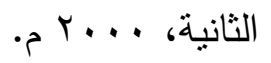

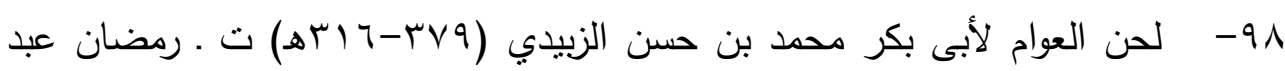

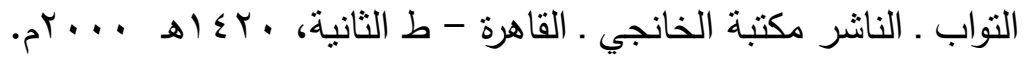

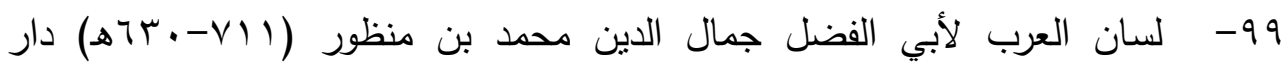
المعارف المصرية ـ القاهرة. . . . اللغة لجوزيف فندريس - تعريب عبد الحمبد الدواخلى، وآخر . مكتبة الأنجلو

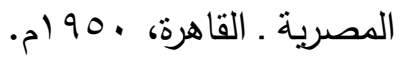

1 ( ا- لغة تميم لضاحي عبد الباقي ـ مطبوعات مجمع اللغة العربية بالقاهرة ـ القاهرة، . 1910 ه $1 \leqslant .0$

$1 \pi$. مجلة بحوث كلية الآداب 


\section{ما نسبه الزبيدي في تاج العروس إلى اللهجة المصرية}

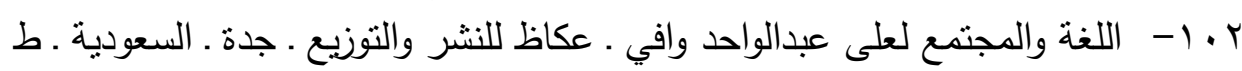

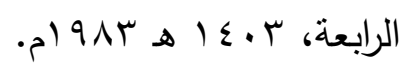

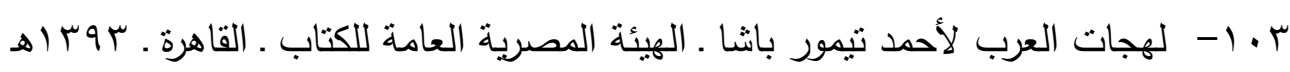
.5) $9 \vee r$

ـ • 1- اللهجات العربية العامية ـ إسكندر المعلوف ـ مجلة مجمع اللغة العربية بالقاهرة . الجزء الأول، ع 9 ام ـ طبع بالمطبعة الأمبرية ببولاق ـ القاهرة.

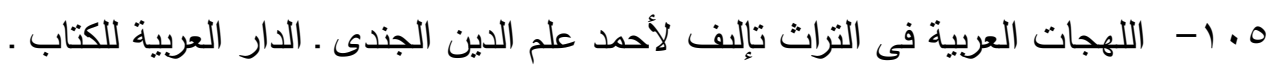
طرابلس . ليبيا.

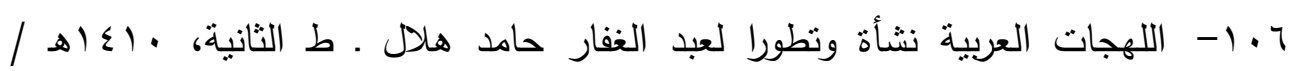
. 99 ام ـ مطبعة الجبلاوي ـ النزعة البولاقية ـ شبرا.

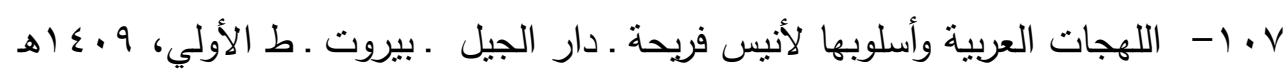

$$
\text { . } 1919
$$

1. 1- مجمل اللغة لأبى الحسين أحمد بن فارس . تحقيق: زهير عبد المحسن سلطان .

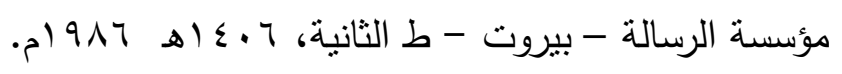

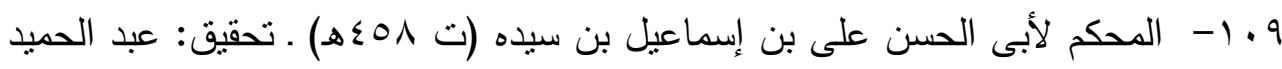

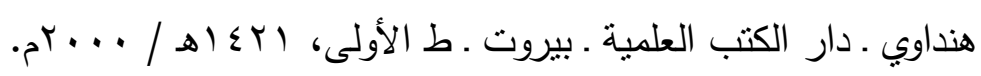

• 11- المحكم في أصول الكلمات العامية لأحمد عبسي بك، مطبعة الحلبي ـ القاهرة ط.

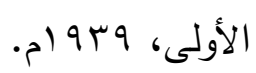

111 - محيط المحيط لبطرس البستان ـ الناشر مكتبة لبنان ـ بيروت ـ ط جدبدة، 19NV م. r 11 - مختصر في شواذ القراءات لابن خالويه ـ مكتبة المتتبي ـ القاهرة. rا11 - المخصص لابن سيده - دار الكتب العلمية - بيروت - لبنان.

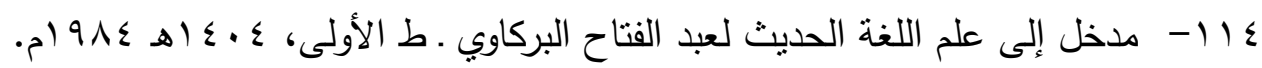

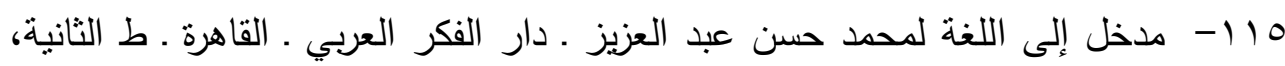

$$
\text { . } 901 \text {. } 901
$$


د/ مصطفى عبد الهادي عبد الستار محمد

11 ا 11 - مراصد الاطلاع على أسماء الأمكنة والبقاع لعبد المؤمن بن عبد الحق، ابن شمائل

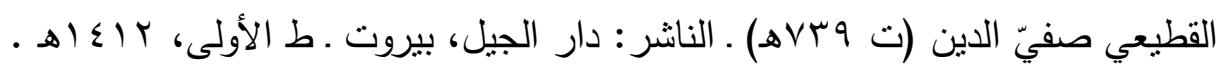

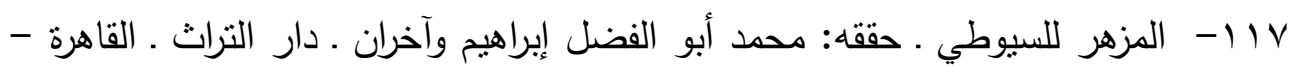
ط الثالثة.

111- مستويات العربية المعاصرة للسعيد بدوي . ط دار المعارفالمصرية ـ القاهرة، • 9 ) 19

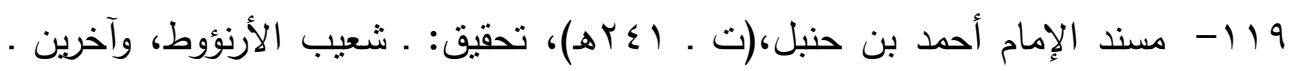

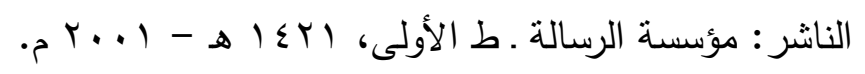

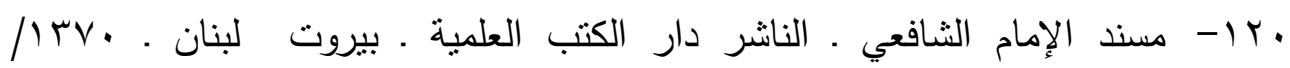
.51901

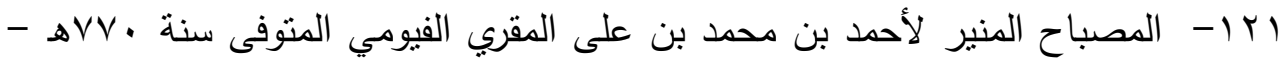

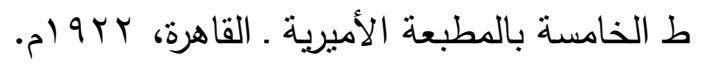

r T - معجم الألفاظ العامية ذات الحقيقة والأصول العربية لعبد المنعم سيد عبد العال مكتبة الخانجي . القاهرة.

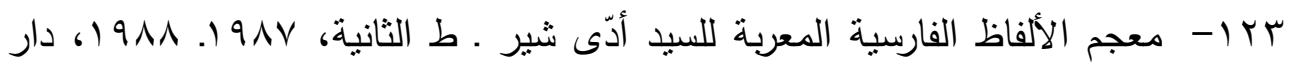

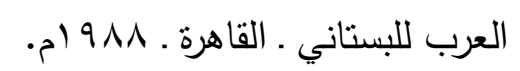

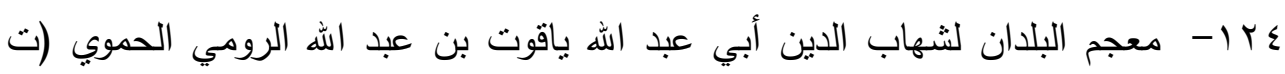

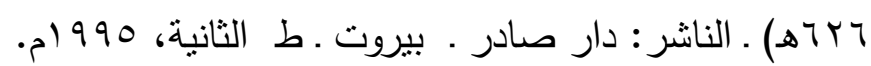

هY ا - دعجم تيمور الكبير في الألفاظ العامية لأحمد تيمور باثنا ـ تحقيق: حسين نصار . دار الكتب المصرية ـ القاهرة، 999 ام. דr ا - معجم التاريخ التراث الإسلامي في مكتبات العالم (المخطوطات والمطبوعات) . لعلى الرضا قره بلوط - أحمد طوران قره بلوط ـ دار العقبة . قيصري - تركيا. ي رץ ا - معجم الثهابي في مصطلحات العلوم الزراعية لمصطفي الثهابي . الناشر مكتبة لبنان • بيروت.

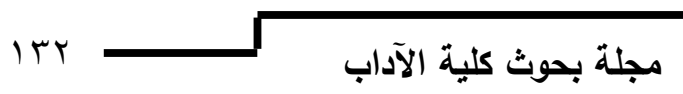


ما نسبه الزبيدي في تاج العروس إلى اللهجة المصرية

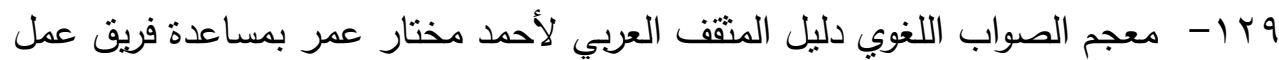

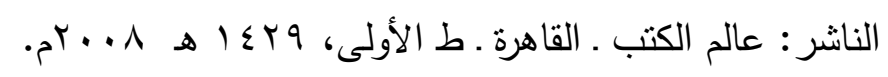

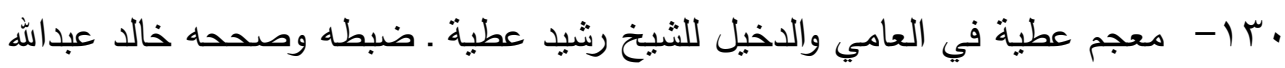
الكرمي ـ منشورات محمد على بيضون ـ دار الكتب العلمية ـ بيروت ـ لبنان.

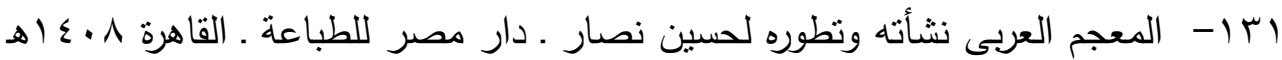

$$
\text { . } 1911
$$

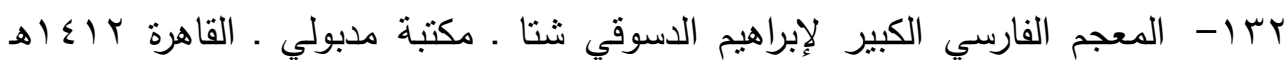
.01994

rrا- معم فصاح العربية وأثرها في التجديد اللغوي لمحمد خسارة، مجلة مجمع اللغة

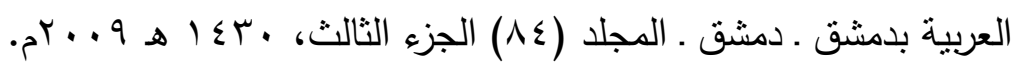

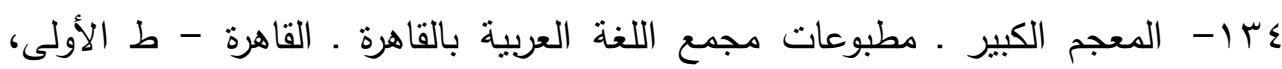
. . . . . . .

هبا- معجم اللغة العربية المعاصرة لأحمد مختار عمر . عالم الكتب بيروت . لبنان،

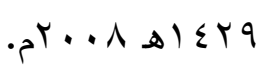

بس ا- المعجم اللغوي العربي لعبد المنعم محمد عبدالغني النجار ـ دار الطباعة المحمدية .

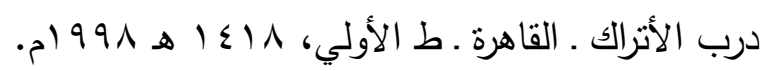

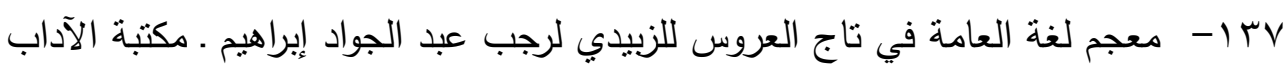

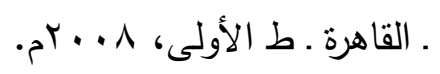

رr ا- - معجم ما استعجم من أسماء البلاد والمواضع، لأبي عبيد عبد الله بن عبد العزيز

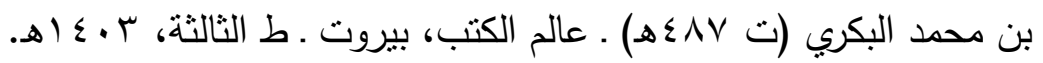
9 ب ا - المعجم الوسيط ـ مطبوعات مجمع اللغة العربية بالقاهرة ـ القاهرة ـ ط الثالثة.

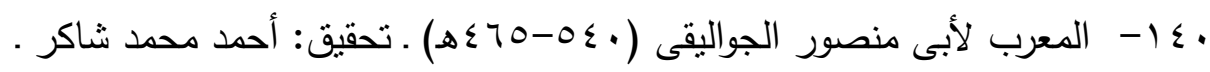

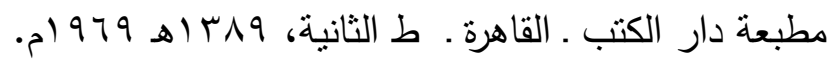
اء ا- المفردات فى غريب القرآن لأبى القاسم الحسين بن محمد المعروف بالراغب الأصفهانى . تحقيق: إبراهيم شمس الدين - دار الكتب ـ بيروت ـلبنان. 


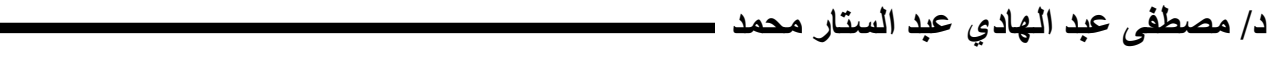

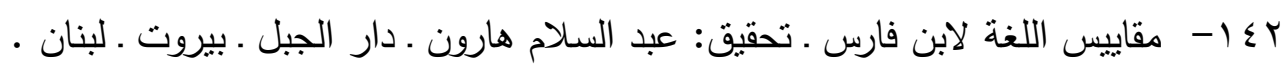
r ا- المقتضب فيما وافق لغة أهل مصر من لغة العرب لابن أبي السرور البكري . تحقيق: هشام عبد العزيز وآخر. الناشر أكاديمية الفنون ـ مصر ــ مطابع الأهرام التجارية

$$
\text { . مصر. }
$$

§ § ا - مقدمة محقق معجم تاج العروس لعبدالستار فراج ـ الناشر وزارة الإششاد والأنباء .

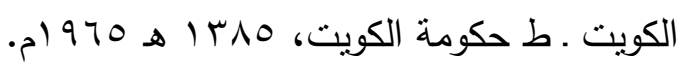

0 ا - المكاييل والأوزان الإسلامية وما يعادلها في النظام اللتري لفالترهنس ـ ترجمه إلى

$$
\text { العربية د كامل العسيلي ـ منشورات الجامعة الأردنية ـ الأردن. }
$$

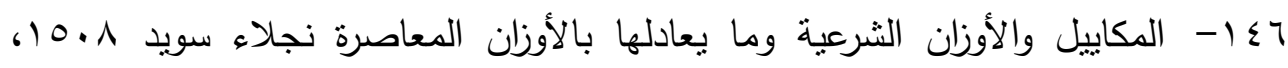

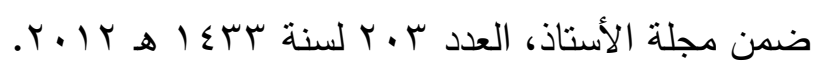

V V ا - المكاييل والموازين الثرعية د على جمعة ـ الناشر القدس للإعلان والنشر والتسويق .

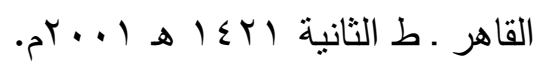

1 ا - - من المشترك السامي العامي بين السريانية والعامية لعبد الرحمن عبد الرحمن . بمجلة علوم اللغة ـ العدد الرابع ـ المجلد ( V ) ـ دار غريب للطباعة والنشر ـ القاهرة. 9 إ- ملامح في فقه اللهجات العربيات من الأكادية والكنعانية وحتى السبئية ـ لبهجت

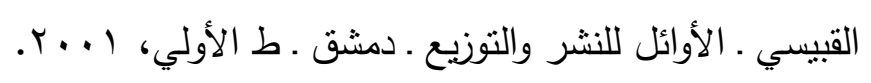

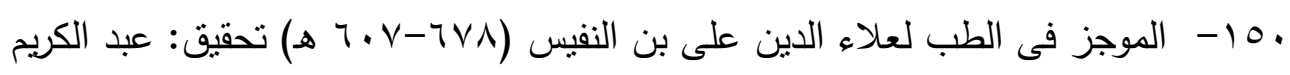

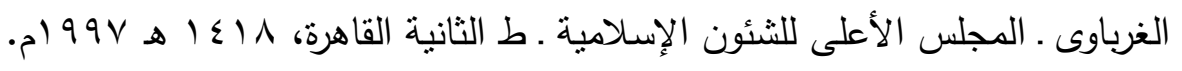
101- المواعظ والاعتبار بذكر الخطط والآثار لأحمد بن على بن عبد القادر، نقي الدين

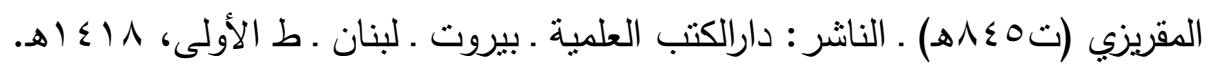
ror- نزهة النفوس ومضحك العبوس لعلى بن سودون البشبغاوي المصري . تحقيق: حسين نصار وآخر ـ الناشر دار الكتب والوثائق القومية ـ القاهرة.

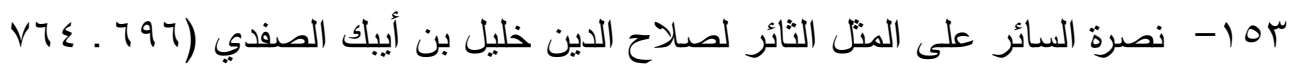
هـ) تحقيق: محمد على سلطاني ـ مطبوعات مجمع اللغة العربية بدمشق ـ دمشق. 
ما نسبه الزبيدي في تاج العروس إلى اللهجة المصرية

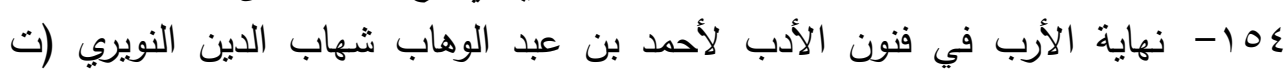

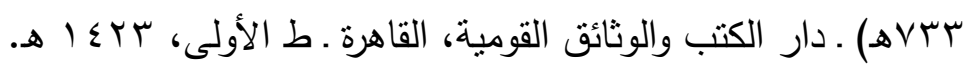

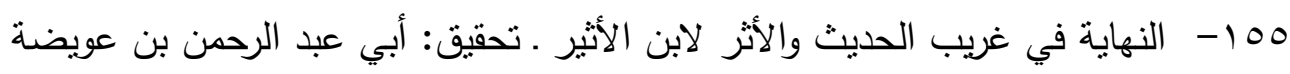

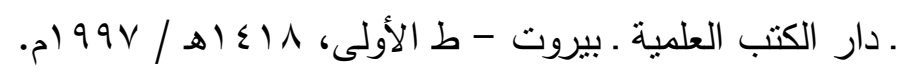

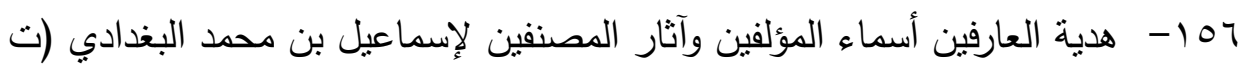

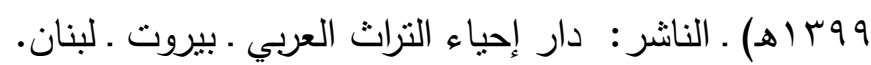

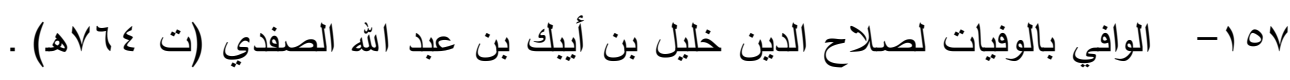

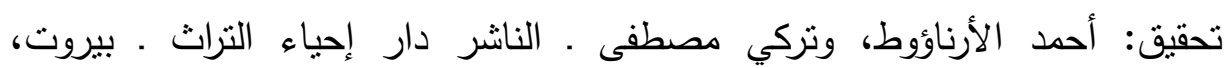
r.... - . 


\begin{tabular}{|c|c|c|}
\hline \multicolumn{3}{|c|}{ فهرس الموضوعات } \\
\hline ص & 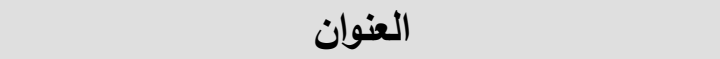 & b \\
\hline$r$ & ملخص البحث & 1 \\
\hline ○ & المقدمة المقة & r \\
\hline$\wedge$ & تمهيد في الزبيدي & $r$ \\
\hline$\wedge$ & التعريف بالزبيدي & $\varepsilon$ \\
\hline ir & آثاره العلمية & $\bullet$ \\
\hline $1 \varepsilon$ & الزبيلي وتاج العروس & 7 \\
\hline 10 & منهج الزبيدي في المولد والعامي & $\checkmark$ \\
\hline ro & مبحث في ما نسبه الزبيدي إلى اللهجة المصرية & $\wedge$ \\
\hline ro & توطئة & 9 \\
\hline ro & اللهجة المصرية وصلتها بالفصحى & 1. \\
\hline rv & مستويات التغير اللغوي في اللهجة المصرية & 11 \\
\hline rq & ألفاظ اللهجة المصرية & - \\
\hline l & 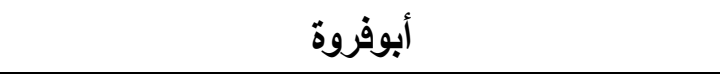 & 1 \\
\hline 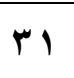 & الأشثق & r \\
\hline rr & 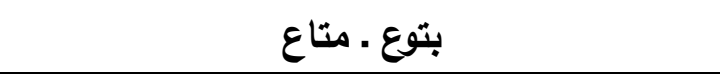 & $r$ \\
\hline r & 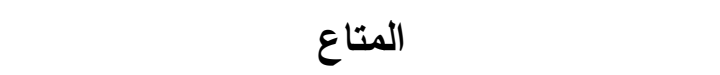 & $\varepsilon$ \\
\hline$r$ & 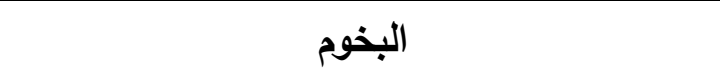 & 0 \\
\hline$r \varepsilon$ & البربخ & 7 \\
\hline$r \varepsilon$ & البرنوف & 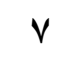 \\
\hline ro & البسلة & $\wedge$ \\
\hline ro & 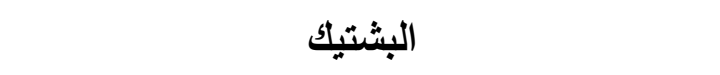 & 9 \\
\hline$\mu v$ & 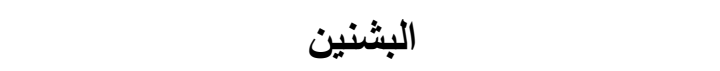 & 1. \\
\hline
\end{tabular}




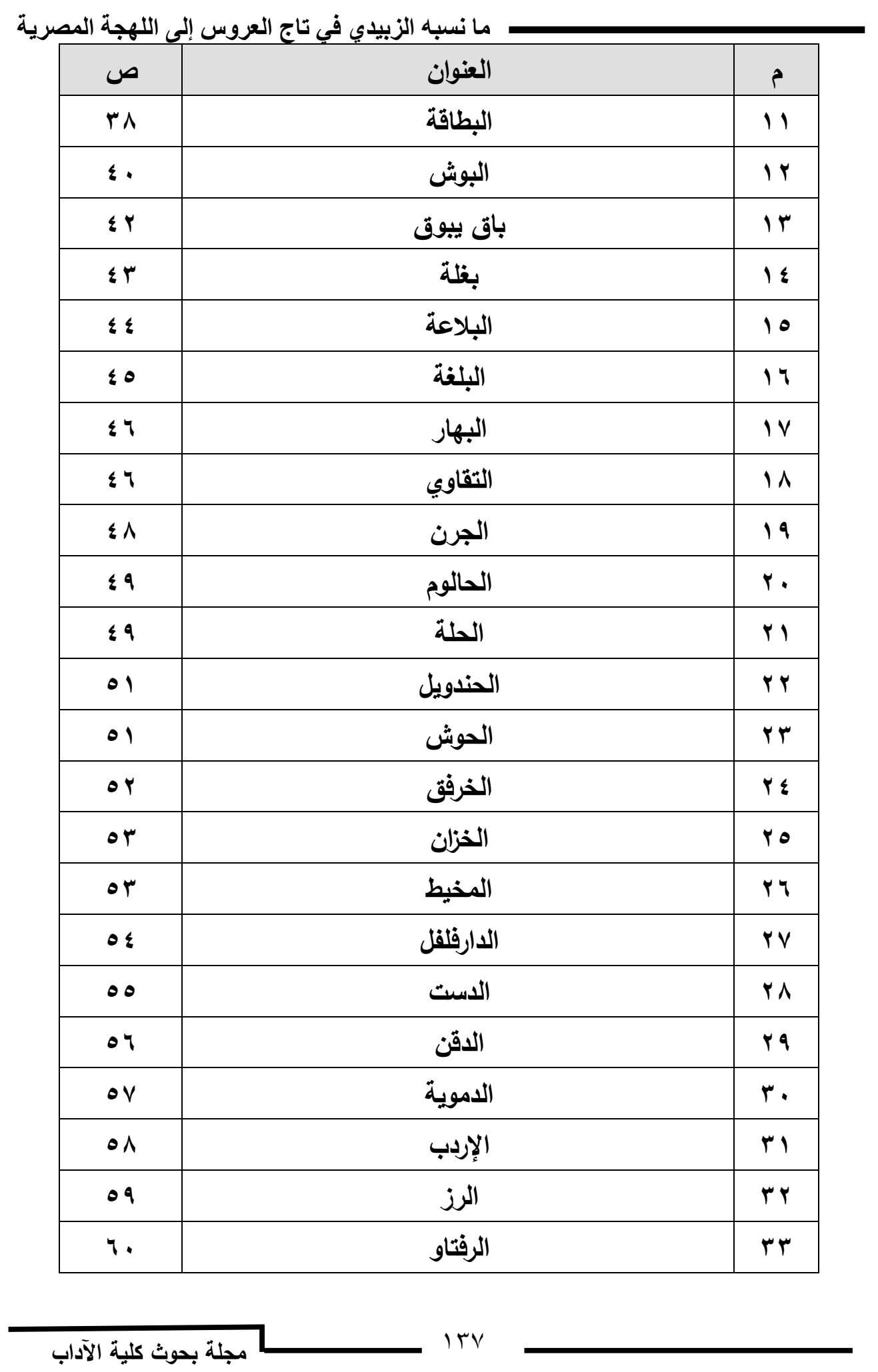




\begin{tabular}{|c|c|c|}
\hline ص & العنوان & م \\
\hline 7. & الركفة & \& \\
\hline 7. & الزحافة & po \\
\hline Tr & الزكيبة & qu \\
\hline יזד & السباطة & $r v$ \\
\hline $7 \varepsilon$ & السرحاب & r \\
\hline 70 & السويياء & $p q$ \\
\hline 79 & المسيد & $\varepsilon$. \\
\hline TV & الشادوف & $\leqslant 1$ \\
\hline 71 & الشراقي & $\varepsilon r$ \\
\hline 79 & شطف & $\varepsilon r$ \\
\hline vi & الشقافة & $\varepsilon \varepsilon$ \\
\hline VY & الشمار & $\leqslant 0$ \\
\hline Vr & الشونـة & $\leqslant 7$ \\
\hline$V \leq$ & صفط & $\varepsilon V$ \\
\hline vo & الصنط & $\varepsilon \wedge$ \\
\hline vo & الصيادية & $\leqslant 9$ \\
\hline V & الطبوع & 0. \\
\hline VV & الطقل & 01 \\
\hline$\vee \wedge$ & الطوب & $O r$ \\
\hline$\vee q$ & طين إبليز & or \\
\hline$\Lambda$. & عاط . ياعاط & O\& \\
\hline Ar & العبدليّ & 00 \\
\hline N & عين جمل & 07 \\
\hline
\end{tabular}




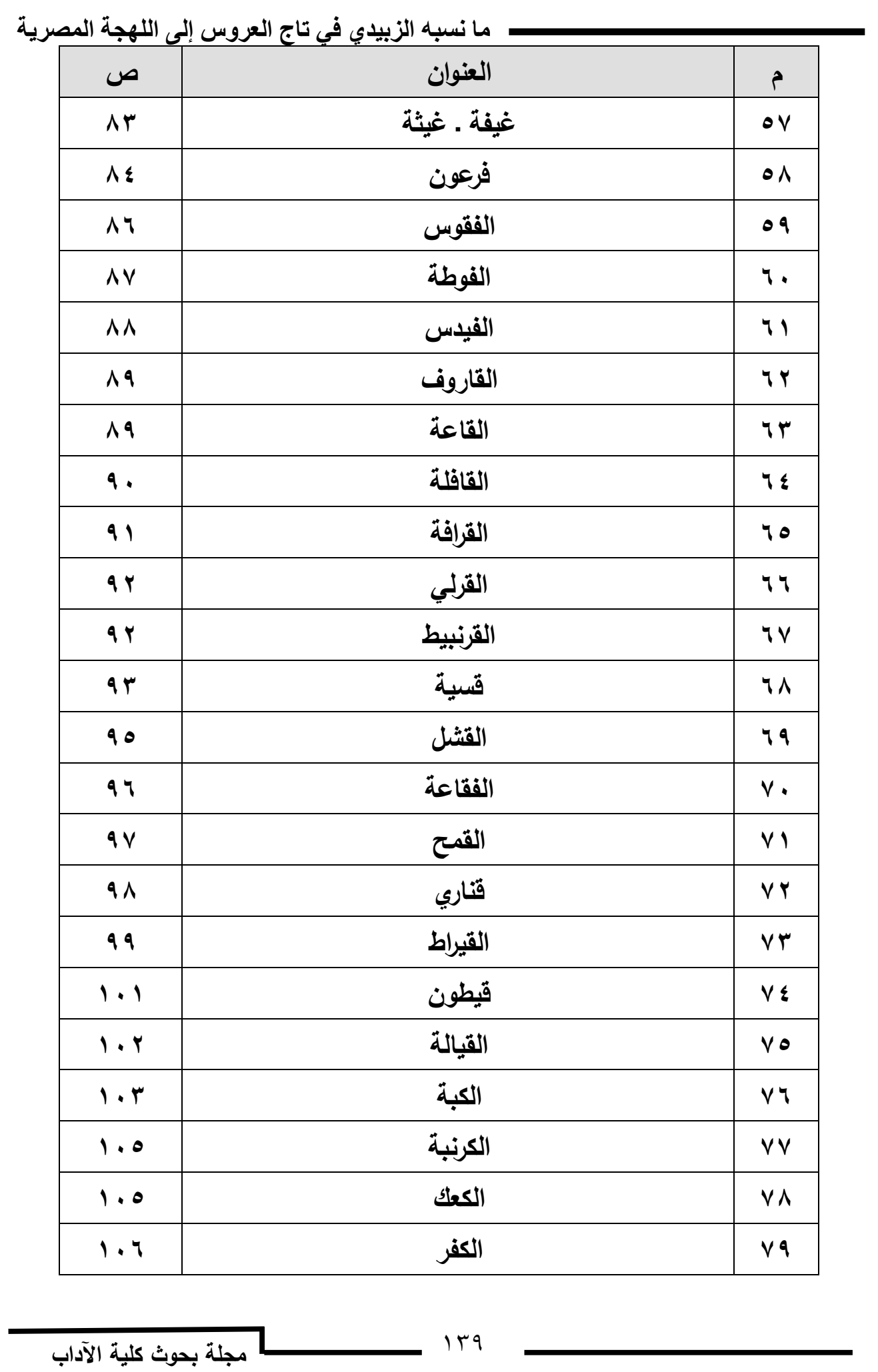




\begin{tabular}{|c|c|c|}
\hline ص ص & العنوان & b \\
\hline 1.9 & لقمة القاضي & $\wedge$. \\
\hline 1.9 & المرسين & $\wedge 1$ \\
\hline 11. & مصر & $\Lambda r$ \\
\hline 11. & الملوة الملو & $\Lambda \mu$ \\
\hline 111 & المن المن & $\Lambda \varepsilon$ \\
\hline 111 & النبوث & ^o \\
\hline $11 r$ & النخوم & $\wedge 7$ \\
\hline $11 \%$ & الهالوك & $\Lambda \vee$ \\
\hline $11 \leq$ & الوسب & $\wedge \wedge$ \\
\hline $11 \varepsilon$ & الويبة & $\wedge 9$ \\
\hline 110 & الويكة & 9. \\
\hline 117 & ياما يا & 91 \\
\hline 111 & اليؤيؤ & $9 r$ \\
\hline 119 & الخاتمة والتوصيات & ir \\
\hline$|r|$ & ثبت بأهم المصادر & $1 \varepsilon$ \\
\hline בצו & فهرس الموضوعات & 10 \\
\hline
\end{tabular}

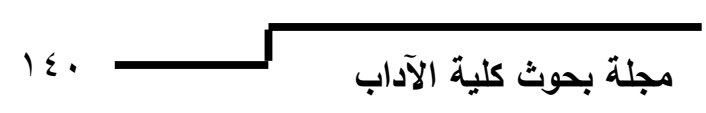

